
From the collection of the

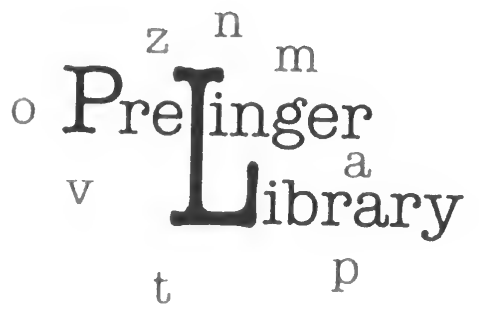

San Francisco, California 2006 

Miracles Ahead! 


\section{THE FRONTISPIECE}

Here is just a glimpse, but an intriguing one, of some of the things which may be possible in the postwar future.

Note the interesting feature of the prefabricated house designed by Simon Breines. A sheet of water on the house's roof helps keep it cool in the summertime.

Just below is the Aerocar, designed by William Stout for Consolidated Vultee Aircraft Corporation. For air trips, the combined wings and outrigger can be attached and the Aerocar leaves the highway for swift cross-country flights.

Upper right is Stout's Helicab. It will be just the thing, he says, for city commuters to use between office and home.

The "prefab" house below, and the trains, trucks, buses and automobiles further down, all will be more attractive and comfortable, and give better service at low cost because of wartime advances in the use of light metals, plastics, plasticbonded plywood and glass.

Study carefully the apartment house of the future, designed by Walter B. Sanders. The building would consist of two distinct elements: the structural frame, including floors and ceilings, and the individual apartments of the tenants. Prefabricate wall and partition units could be installed on order, with the number and placement of windows, size of rooms and closets left up to you.

Material for this frontispiece is used by courtesy of:

Revere Copper and Brass Incorporated; Consolidated Vultee Corporation; U. S. Stoneware Co., producers of Reanite; Bohn Aluminum \& Brass Corporation, Bohnalite \& Bohnolly Products; L. C. Chase \& Co., makers of Chase Velmo upholstery. 


\section{Digitized by the Internet Archive in 2006 with funding from Microsoft Corporation}


Miracles Ahead!

\title{
BETTER LIVING IN THE POSTWAR WORLD
}

\author{
By \\ NORMAN V. CARLISLE \\ and \\ FRANK B. LATHAM
}

New York

THE MACMILLAN COMPANY

1944 


\section{Copyright, 1944, by}

\section{NORMAN V. CARLISLE.}

All rights reserved-no part of this book may be reproduced in any form without permission in writing from the publisher, except by a reviewer who wishes to quote brief passages in connection with a review written for inclusion in magazine or newspaper.

\section{Second printing.}

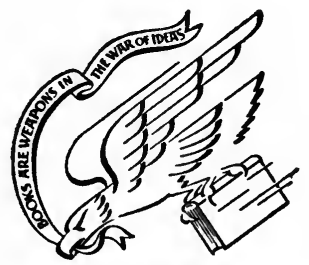

A WARTIME BOOK

THIS COMPLETE EDTTON IS PRODUCED DN FULL COMPLUNCE WTTH THE COVERWMent's ReCULATIONS Fon CONSERvine PNPER AND OTHER ESSENTIAL MATERULL 


\section{AUTHORS' FOREWORD}

"Miracles AHEAD—but when?"

That is the most baffling question that confronted the authors when they undertook this venture into the troubled realm of prophecy. In fact, we may as well confess that there were times when we doubted the wisdom of a title containing the word "miracle." We heard altogether too many dire warnings- "Don't get people's hopes up." "These things take time." "Utopia can't be built in a day."

On the other hand, we felt safe in depending on the unequivocal assertions of such hard-headed businessmen as Edgar M. Queeny, who did not hesitate to say, "The possibilities of the future, now that industry has embraced science, are so limitless that only one forecast can be made with certaintythat the most extravagant prophecy will fall short of potential accomplishment!"

We had no intention of making this book an "extravagant prophecy." We think it's a conservative one. But we just can't say when. That is not dodging issues. We know that after listening to the perfectly sound arguments of people who have every good reason to know. For example, Walter Dorwin Teague, the noted industrial designer, squares off against his fellow industrial designer, Raymond Loewy, with completely opposite views.

Says Teague: "It is my firm conviction, based on direct knowledge, that as soon as production can be resumed after victory, the public will be offered new and greatly improved models in most, if not all lines of consumer goods. And, as soon as retooling and testing can be accomplished, new 
products will appear which will make the fanciful predictions that decorate our advertising pages today seem commonplace."

Says Loewy: "To the scrap heap of discredited but once popular theories-such as the Townsend Plan, Technocracy, the Bolshevik menace, successful Nazi appeasement-please add another, the immediate Postwar Dream World. To be honest-and certainly the time is ripe for facing issues squarely-the wonderful new products will be a long time coming, if they ever do."

To be perfectly frank, there is a controversy going on. It is a heated controversy in which the authors feel something like innocent by-standers. Essentially, it has been our purpose to present a reporter's picture of what is happening today, what is already on the drawing boards, what scientists and industrialists think can be done to provide "better living in the postwar world." So-forgive us-we are going to leave it to the reader to decide when. On the other hand, we do not think that some pretty remarkable things will be too long in coming. We think that by the time you get around to cashing in those war bonds you have been buying there will be some fascinating new ways to spend the money. We think that the dynamics of American business drive it ahead, sometimes even faster than the businessmen themselves expect.

We want especially to thank the many industrialists, scientists, designers, engineers and sales managers who have given so much of their time to pass on their views for "Miracles Ahead."

Norman V. Carlisle

Frank B. Latham

New York City January I, 1944 


\section{CONTENTS}

I TOMORROW's WORLD

War-production techniques have created the tools and equipment necessary for the manufacture of startlingly new articles for civilian use after the war ... Clues to the future: Extraordinary new metals that will transform cars, trains, and ships . . . Electronic "watchmen" . . . Fabulous plastics . . . New uses for paper, wood, and glass... . World transportation by air ... Private flying ... New agricultural techniques ... Population shifts.

II A Castle for Every MaN

The prefabricated house . . The War Set the Pace . . . Standardization?. . The Circular House . . . Buy Your Home-Rent Your Land . . . Tradition Takes a Back Seat ... Trading in Your Old Rooms ... Apartments of Tomorrow ... Design Your Own Apartment . . . Problems Ahead.

III Little Miracles

Appliances of tomorrow ... Modern Lighting Equipment . . . "Laundering" the Air . . . Smokeless Furnaces ... Soundproofing . . . Proper Acoustics . . . Radiant Heating . . . Built-in Furniture . . . Mass-Produced Closets . . . Small Items That Mean Comfort . . . A Modern Bathroom . . Refrigerator Drawers . . The Hamby "Kitchenless House."

IV CaRs OF THE 1960's

Materials used in the manufacture of war planes will be used in the automobiles of the future ... New Low Prices . . . Old Ideas Die Slowly . . . Engines Move Back . . . New Metals for New Motors ... Renaissance of the Diesels . . J Jeeps for the Farm . . . The Plastic Car . . . New Gasoline 
Future Traffic Solutions ... The Radio Traffic Cop . . . Radar for Driving Safety . . Postwar Dilemma.

V Your Flying Fuivver

Development of private flying . . . Your First Plane -the Helicopter. . . How to Fly a Helicopter . . . Sikorsky's First Helicopter . . . War Duties of the Helicopter . . . Postwar Tasks of the Helicopter . . . The De Bothezat Helicopter . . . The Helicab ... The Autogiro... The Convertaplane ... New Light Planes . . . Stout's Sky Car . . . Simplified Flying Techniques . . . Safety at Night.

VI Global Transportation

You will visit foreign lands ... New Shipping Centers ... \$10,000,000 Seadromes . . . Passenger Stratoliners ... Air Cargo . . . The Army's Air Transport Command . . The Naval Air Transport Service ... Speedier Loading Techniques ... Glider "Freight Trains"... The Rocket Motor ... Radio Aids ... The Finest Airways System on Earth ... Solutions for Postwar Unemployment . . . Other Postwar Issues.

VII By LAND AND SEA

IOI

The truth about air cargo . . ."The Battle of Transportation". . . Trucks and Busses Hold Their Own ... Shipbuilding Magic ... The Diesels Step Ahead ... Airplane and Ship Competition.

VIII Your New Servants: The Electronic "WATCHMEN"

The open door to a miracle world . . . Edison Discovered the Secret . . . Radar . . . Radio-Frequency Heating . . . X-Raying Steel . . . The Photoelectric Tube ... Testing the Ripeness of a Melon . . . Checking Moving Objects . . . New Medical Servants.

IX New Television and Radio Services

How long will television be "just around the corner"?. . . Television Service in England . . . Spy- 
ing upon the Enemy via Television ... Television Prospects in America ... The Actor Comes into His Own ... The Fighting Man's "Nerve Center" . . . Indestructible Radios for the Armed Forces ... Radio Safety Devices . . . A Word about Frequencies . . . Sending Pictures by Radio.

\section{Chemistry Magic}

The incredible plastics . . . Precious Synthetic Rubber . . . How Synthetic Rubber Is Made . . . Bless John Barleycorn ... "Bathtub" Rubber . . . Synthetic Rubber Is Here to Stay . . . Untapped Resources in Natural Rubber ... An Exploit of the Century . . . Fabulous New Wealth ... The Great Compounds . . . The Super-super By-Product: Coal Tar... A Ton of Coal ... Oil, the Chemist's Proxy for Coal ... The Plastics... The Hard Resilient Plastics ... Plastics from the Ocean ... Replacing Light Metals... Plastic Bearings ... Achieving the Impossible ... Winning Chemical Leadership from Germany . . . Breaking the Japanese Camphor Monopoly . . . Creating New Wealth in Agriculture . . . Synthetic Textiles . . . Postwar Predictions.

\section{Metals That Build New Worlds}

Manufacture of war planes stimulated development of new metals ... The Story of Aluminum ... The Ocean as a Treasure Chest . . . One Pound of Magnesium . . ."Tailor-Made" Steel . . . Precious Common Metals ... Uncommon Metals ... Beryllium-the Magic Metal ..."Powder Metallurgy."

XII Wood, Paper, and Glass Transformed

New treatments of paper . . . Nazi Germany's Reliance on Wood ... American Advances in Wood Chemistry ... Warm Clothes from the Bark of Trees... New Treatments for New Tensile Strengths ... Forest Conservation . . . Glass Miracles ... New Techniques in Glassmaking. 
XIII Fortunes in Agriculture

Solutions for postwar surpluses . . . New Uses for Skimmed Milk ... The Soybean ... The Castor Bean-a New Treasure... Flax Straw for Cigarette Paper.... Our Own Herbs and Drugs... Cotton By-Products . . . Cottonleather . . . Cotton Fire Hose . . . Cotton Roads . . . Corn for Photographic Films . . . Oat Hulls in the Synthetic-Rubber Field . . . By-Products of Wood . . . No Soap Shortage Ahead ... Soil Building ... Soil-less Agriculture ... Farming in the Desert ... Growth-Promoting Techniques . . Making the Farm More Livable.

XIV Food for Buoyant Health

Food shortage an old story in America . . . Urgent Need of Food Education . . . Uninformed Buying ... Wasted Minerals ... Napoleon Counted on Food . . . Protein Shortages the Most Deadly . . . Dehydrated Foods to the Fore . . . The Mechanical Cow.

\section{Medicine Looks Ahead}

First-aid procedures at the front . . . New Medical Kit . . . The Hospital Corps at the Front . . . Blood Plasma . . . Mobile X-Ray Unit . . . The "Closed Treatment" for Fractures . . . The Base Hospital ... Mobile Bacteriological Laboratory... The Navy's Hospital Ships . . . The Magical Sulfa Drugs ... Penicillin-Germ Destroyer ... Gramicidin -New Microbe Killer . . Streptothricin-Another Microbe Killer... Quinine Substitutes"Health Bomb" for Mosquitoes . . . Waging War on Epidemic Diseases . . . The Amino Acids Promote Health and Beauty . . . Nature's Most Powerful Vitamin ... A Clue to Cancer . . . Research Work on the Common Cold . . . Blood Plasma for Civilian Use ... Transplanting Vital Organs ... A Cure for Deafness ... . Treatment for Hypertension ... Regional Anesthesia ... Electronic Aids . . . Onion "Broadcasts" . . . Old-Age Treatments ... Air-Age Problems. 
Contents $\quad \mathrm{xi}$

XVI More Miracles Ahead 26r

Using the atomic energy in a lump of coal to run a factory for a week ... The Amazing Cyclotron ... Harnessing the Sun's Rays . . Electricity as Cheap as Water ... Agricultural Yields Tripled ... Ships without Crews . . E Edible "Cans" .. . The Vortex Gun.

INDEX 

Miracles Ahead! 



\section{I \\ TOMORROW'S WORLD}

IT IS ONE OF THE major ironies of human history that modern war has contributed so much to material progress. Barbaric and wasteful as the two wars of this century have been, each has brought some compensating gains that may be said to make up in some measure for the staggering loss in blood and treasure. The pressing need for the production of the machines of war has launched new industries, stimulated new skills, created new products and ways of producing them. Added together they present a startling picture of postwar possibilities. It is perhaps true that the foreshadowed changes would have come anyway, but the time element has been telescoped. Science and industry have proved their amazing ability to work together in the interests of destruction. Their partnership, strong before the war, has become stronger still. And now both have new tools to work with. Anyone with a knowledge of these tools can have no doubt that tremendous changes in American living lie directly ahead.

Tremendous changes in the American scene lie directly ahead. Most of us have realized that the war would bring new developments-that this country could not take an active part in the world conflict and remain the same. We know that the first World War brought about changes in this country that were more revolutionary and far-reaching than all the events of the previous fifty years. We are aware that this war is sweeping away many familiar things and ushering in new ones. But few of us guess the extent and scope of the changes that loom before us now. 
There is a profound difference not only between the nature of the war that we entered in 1917 and that which we entered in the 1940's, but between the situation that confronted the United States in 1917 and that which we faced during the 1940's. These differences mean far more drastic changes during the postwar era of World War II than was the case after the last conflict.

In 1917 we entered the war fresh, with a long period of peace and prosperity behind us and with an abundance of natural resources and man power available. Within a remarkably short period of time our industrial technicians found ways and means of producing the immense quantities of war matériel required. They had the advantage of an abundance of everything needed for the task. Time was more precious than materials and they were free to squander prodigious quantities of raw materials in various trial-and-error procedures that saved time. Incidentally, the war fronts to be supplied were confined to a fairly small area of one continent!

In the 1940's we entered a titanic struggle on a world-wide basis-after an engulfing depression that had lasted nearly a decade and that had weakened and dispersed our man power; depleted our reserves of tools, machines, and raw supplies; disrupted our economy. Our industrial technicians faced a superhuman task. There was a desperate shortage of plant and factory space, machines, equipment, and materials available as compared with the amount needed. There was an even more critical shortage of skilled workmen.

New inventions, discoveries, and procedures that had been introduced years earlier, and that would have greatly expedited the mass-production techniques needed, had been set aside during the depression years. Producers had been unable to embark on new. ventures in the face of an uncertain market. Discouraged about this situation, our leading designers, engineers, chemists, and technicians had pigeonholed new 
ideas; and blueprints and chemical formulas of all kinds were allowed to gather dust in office files for years. Technological advances had been brought almost to a standstill as compared with the progress made in normal times.

The dramatic and important difference between this situation and that of 1917 was the fact that, in 1940, time, men, and materials were all equally precious. In this fact lies the clue to the amazing peacetime developments on the horizon. Shortcuts of a breath-taking variety were in order. New techniques in mass production on a vaster scale than anyone had hitherto believed possible were essential. Every possible device for saving man hours, especially of skilled workmen, had become imperative. There was no margin for waste. There was no real margin of safety for error and everyone knew that errors would be made. Yet many dangerous gambles had to be taken.

For example, blueprints for new tools and machines, chemical formulas on paper, and drafts of new processes utilizing waste materials that have been gathering dust in the files for years are of limited value. Performance records are urgently necessary. But time did not permit the exhaustive investigation and checking ordinarily undertaken. In many cases technicians were obliged to go ahead with production plans without the benefit of essential data, relying on routine tests and their previous experience with similar tools and procedures. The risk was staggering. During this period.technicians lived with their hearts in their throats. Every scrap of material had to be made to go further than it had ever gone before. Then came the crisis in raw materials. In some cases engineers called upon the industrial chemists actually to create new materials to take the place of raw supplies.

As Theodore G. Joslin, Director of Public Relations for E. I. du Pont de Nemours and Company, revealed, "Our laboratories were scoured for new things. The scarcity of 
conventional materials led producers to turn to anything promising in the way of substitutes."

Procedures that no one in his right mind would have even contemplated in peacetime were grimly tackled and made to work. Radically new materials were employed for uses that seemed, at first thought, utterly preposterous, as in the case of plastics for bearings and for cartridge cases. Traditional methods of assembly were swept aside for new ones. In some plants the break with the past was so complete that anyone visiting them in 1940 and then again in 1942 would imagine that there had been a lapse of twenty years instead of two between the visits.

The roster of men who gave their last ounce of energy, wit, and ingenuity to the task of making us ready for war is a long one. It includes eminent scientists, engineers, and designers; many brilliant youngsters who sprang out of nowhere during the emergency and whose names are as yet unknown to us; and also a large number of familiar prosaic business personalities with whom we do not ordinarily associate heroic exploits. Nevertheless this group of men comprises the list of frontline heroes without whom the war could not have been prosecuted-though the risks they assumed involved too many sleepless nights and days and too many cups of black coffee rather than bullets and shrapnel. The day-and-night thinking and planning that went on in the designing rooms and laboratories during this zero hour made possible the war-production miracles we are witnessing today.

\section{New Resources for Peacetime}

The fantastic achievements of industry during the past thirty months mean significant developments in the postwar era. As strange as it may seem, considering the appalling drain on our resources that war always entails, we will emerge 
from this war with new resources of greater potential value than any we possessed previously. We have learned how to tap the ocean for the minerals needed for the manufacture of cheap, powerful lightweight metals superior to any made before the war, thereby making the ocean a new treasure chest. The science of electronics has been advanced to a point where its value is now comparable to the acquisition of one bundred million new skilled workmen. We have developed plastics and new processes for treating wood, paper, and glass that are almost equal in value to the discovery of new elements.

These facts alone mean a great abundance of beautiful, durable articles for everyday use at a fraction of the cost of prewar merchandise. But there are many many more new inventions and processes of almost equal importance now being employed for war production (a large number of which cannot be revealed at this time for obvious military reasons) that will later mean greater comfort and convenience than we have ever dreamed possible.

Way up at the head of the list of miraculous items that we may expect to see and use in the postwar world are passenger cars that can be transformed into airplanes or helicopters, electronic "watchmen" that can test the ripeness of a melon or count the number of people in a room and turn off the lights when the last one has departed, glider "freight trains" hitched to a "locomotive" plane carrying cargo overhead. We will enjoy the benefits of new processes that can now transform the bark of trees into warm wool cloth, paper into weatherproof panels for the walls of houses, glass so resilient that it can support the weight of an elephant, electric light that will also destroy bacteria, and even a process that will transform sawdust into raw sugar-to name a few of the things to come.

The mass-production techniques now being employed for 
gargantuan quantities of war matériel will later be used to turn out, by the thousands, new cars that are lighter and swifter than any we have seen to date and that will be a third lower in price than the cheapest prewar car; prefabricated homes equipped with modern lighting, plumbing, and airconditioning units (homes fit for kings); helicopters and small easy-to-maneuver planes for civilian use to be sold at the price of a good car; new tools, appliances, and machines of every type and description.

\section{The Revolution in Transportation}

It is difficult for most people at this time to grasp the significance of the new metals that have been developed for airplane manufacture. These powerful lightweight metals will do as much to transform the appearance of tomorrow's world as will any other thing. They will take the place of many heavy, cumbersome, unwieldy metals previously used for buildings and conveyances. We will have new cars, trucks, busses, trains, and ships made with these metals that will be thousands of pounds lighter in weight, far cheaper to buy and also to operate. All transportation in the future will be swifter, quieter, safer, and less costly.

But perhaps the most striking innovation, which will make all of us peer heavenward more often, will be the introduction of helicopters for a variety of uses. A number of applications have already been filed with the $\mathrm{CAB}$ for helicopter services-one company requesting "Helicopter service to carry air mail and express to and from the rooftops of over four hundred post offices and railroad stations in the six New England States and New York."

We can also anticipate helicopter service to and from large cities and their outlying suburbs and the use of many privately owned helicopters for family week-end trips and for 
summer commuting to and from the "place in the country." Before the end of this decade it is more than likely that-as Igor I. Sikorsky, the designer of the helicopter bearing his name, believes-there will be more than one million helicopters in everyday use in the United States. They are the "flivvers" of tomorrow.

\section{The Change in Population Centers}

Every improvement in transportation in the past has had profound effects upon the development of cities in this country. The first cities were located at navigable harbors. The steamboat made possible the growth of cities inland along navigable rivers. The railroads opened the West, and cities made their appearance on vacant prairies, up in the mountain passes, and in the distant valleys of the South, West and the North. The air transportation of tomorrow means new changes. The trend toward decentralization that has already commenced will be sharply accelerated by the cheap air routes of the postwar era. There will be many more allyear-round country homes used by city people who will commute to work by air. New summer resorts will make their appearance in Alaska and the upland regions of South America. Vacationing on other continents, however, is certain to become a general practice among Americans in the future. The large air-line companies are already working on plans for three-cent-a-mile global air service.

\section{Nerw Business Opportunities}

All of these changes will create the need of many new agencies, services, and supply sources. Every airfield along a regular transportation route will become the center for new stores, shops, and office buildings that will be erected close 
by; for the railroads will carry more and more freight and fewer passengers, a prospect, incidentally, that does not wholly displease them. There is a far greater profit in freight service than in passenger service. The more planes there are in operation, the more freight the railroads will carry; for the manufacture and operation of planes mean more transportation of oil, coal, ore, steel, machinery of all kinds.

The manufacture of thousands of prefabricated houses, new cars, helicopters, planes, and household appliances will obviously call for a vast army of salesmen, brokers, agents, and promoters-nearly five times as many as were needed during the nineteen-twenties. Servicemen by the thousands will be needed for repair and maintenance work on these homes, cars, and aircraft. The need for thousands of small businesses will automatically appear as the new patterns of living become crystallized.

Another slant on postwar business worth keeping in mind is the fact that for more than a decade before we entered the world conflict we went through the most critical period of underconsumption (compared with our productive capacity) in our history. By 1939 there were miles upon miles of building surfaces in need of paint and repair from coast to coast, miles upon miles of plumbing and plumbing equipment hardly fit for use and, in many cases, a menace to community health. There were millions of homes in which electrical appliances, furniture, draperies, and fixtures had become worn, shabby, or broken and in need of replacement. Before these needs could be supplied, we entered the war and the curtailment of goods for consumer use began. To sum up-the underconsumption of the necessities has gone on in this country for nearly fifteen years! Meanwhile millions of Americans have been earning higher wages and salaries than ever before.

Barring inflation or some unforeseen eventuality, we have reason to expect a boom of greater proportions than anything 
we have known before and, with it, the introduction of hundreds of new products along the lines already suggested and many others too. Giant strides in agriculture are being ushered in with the stimulus of the serious food shortages. Every large food manufacturer has new foods and new food products to introduce to the public at the close of the war. Many of these products were developed for use by the armed forces and offer new taste thrills as well as high nutritive values. Others came about through laboratory research undertaken during the food crisis.

The textile field has likewise benefited by the stimulus of wartime exigencies. We shall see a great variety of beautiful new fabrics with finer wearing qualities at lower prices as soon as the resumption of the manufacture of consumer goods is permissible on a peacetime basis. Research carried out by manufacturers and by government technicians in order to find ways and means of supplying the armed forces with a great number of durable fabrics suitable for different climates, and for use under varying conditions, resulted in new techniques and processes whereby magnificent fabrics can be produced for a fraction of their former cost.

\section{A New Era of Individualism}

While discussions on the pros and cons of collectivism and individualism have been under way during recent years, our engineers and inventors have been busy with blueprints for new machines and devices more certain to change the course of our destiny than all of the conversations of the past one hundred years. Nearly every large aircraft company in the United States has blueprints on hand for giant air liners, some of them three-decker types with promenade decks, lounge and dining rooms, and accommodations for about two hundred people-planes for commuter service to and from New 
York and London, New York and Brazil, New York and Buenos Aires, and other points of the globe. Clearly a new low-priced air-transportation era will be ushered in with the end of the war.

Where we once faced the wilderness of our West with horses and covered wagons, intent upon building a new civilization, we now face our ocean boundaries and look upon continents only hours away that need our skills, production techniques, and research procedures for the building of a sounder, better civilization. Unless we find ways of raising the standard of living for the populations of other countries, we cannot hope to maintain our own standards for long. This immense undertaking lies not in the distant future but in the very near future. The commuter air service between continents is one means of making this feasible. Our businessmen, craftsmen, and technicians will be able to travel to and from South America, Africa, Australia, and the Far East in a matter of hours, not weeks or months. Where opportunities for establishing new businesses in foreign lands existed in the past only for large corporations, low-cost air service will make it possible for the enterprising individual to launch new services and agencies in other countries too.

The world we knew yesterday has already slipped around the corner and a new one beckons. Our frontiers, in the old geographical sense, have vanished. We face a new world in which the reward for individual ingenuity, wit, and initiative will be higher than it has ever been before. It will be a world that will call for daring and imagination. We will be confronted by problems with which we have had little or no previous experience, and by opportunities so new and strange that they will challenge every ounce of resourcefulness we can muster. A certain readiness to accept new ideas and to adjust to new situations will be demanded of all of us.

The story of the new inventions, discoveries, and processes 


\section{Tomorrow's World}

revealed in the following chapters of this book suggests the scope of the changes before us. In each innovation there are a score of business opportunities. It is possible that the commercial development of these innovations may bring even greater changes than anyone can visualize at this time. 


\section{II}

\section{A CASTLE FOR EVERY MAN}

Let us SAY that the year is 194-- You have decided that you need a new home. You will be able to order it from your local department store or from an agent in your town who sells cars, "family-size" airplanes, helicopters, and houses. You will make a down payment on the house and arrange to pay the balance in installments. Since you have already rented a lot, you will now order a local contractor to build the cement piers that will be required for the foundation of your new home. This done, you will set the date for the delivery of your house and at the same time you will order the moving men to deliver your furniture.

When the day comes, your new dwelling will arrive in a large truck. Six men have been sent along to erect your house. They will haul the floor, wall, and ceiling panels from the truck. Meanwhile a crane will lift the utility unit from the truck and place it on the foundation. This unit is the "heart" of your house. It consists of a section of the bathroom and kitchen floors, plus the upright wall dividing the two rooms, and all the bathroom and kitchen equipment. The copper pipes for water and drains are inside the panels of the utility units, ready to be connected with the utility lines from the street.

When the "heart" of the house is in place, the other sections are fitted together around it. They fit snugly and are airtight. Next come the room panels and the outside wall panels which form the frame of the house. Then the roof and ceiling panels are lifted into position and fastened down. 
While you are admiring the color schemes of each room, the moving van will arrive with your furniture. Your house is ready. By nightfall you will be seated at the dinner table in your dining room enjoying your first meal in your new home.

No hammering of nails or sawing of lumber went on while your house was being erected. There were no grunts or groans from the workmen as they lifted the hurricane-proof but light panels into place. Nor did the plasterers, painters, or paper hangers put in an appearance. The panels of your new home have a resilient finish, in the tones you prefer, that will resist sunlight, rain, boiling water, and any hard knocks the children or moving men may deliver. All that you will need to keep this finish looking like new is a dustcloth.

When you enter a bedroom and close the door, you will find that the noise from the living room stays outside. Spacious closets (already fitted with shelves, chests, and drawers) which form partitions between the rooms will make the house almost soundproof. The wall panels are also packed with an insulating material that swallows up sound.

\section{The War Set the Pace}

Does this story seem fantastic? A good many sound businessmen think it is not, although there is undeniably considerable controversy as to just how soon such a picture will be an actuality.

More than fifty companies are now engaged in the manufacture of prefabricated houses. Some of these houses are being shipped to the war fronts to be used for hospital units, executive quarters, and barracks. Some are being rushed to our own crowded industrial centers where the housing shortage for war workers grows daily more acute. Later, at the close of the war, a large percentage will be sent abroad and 
used in the devastated areas of Europe, Russia, and the Far East. At this time the prefabricated house will become available to private individuals too.

You will get the benefits of this manufacturing experience, these opportunities for checking and testing the new type of dwelling, and you will also get the use of the marvelous new lightweight, resilient, powerful materials, developed for building planes, tanks, and battleships, that will later be adapted to peacetime uses. Your new home will be as strong as the ancient castle that was built with walls four feet thick! Most important, it will be planned and designed by America's best engineering brains.

As Bror Dahlberg, president of the Celotex Corporation, revealed, "We have learned more about building houses in the past two years or so than we learned in the preceding two decades. We have been forced to develop new materials and adopt new methods of construction because accustomed materials have been impossible to get and the old methods of construction were too slow."

As a result of the "know how" gained in war production, many newcomers will enter the prefabricated-housing field when the war ends. Certain auto companies already are in the household-equipment field. Chrysler makes Air-Temp airconditioning units. General Motors produces Frigidaires. Nash turns out Kelvinator products. The aviation industry's experience in the manufacture of panels for airplanes should permit it to step easily into prefabricated-housing manufacture. Shipyards also have the equipment and the trained men needed to handle machine-made houses. They might build houses in sections as the TVA engineers are doing. The TVA house is sliced into four three-ton sections. Each section is a complete vertical slice of the house. Everything is in place and ready to function when the house is put together. Tracks are laid on the foundation and pulley wheels under each sec- 
tion expedite the assembling. When the sections are properly lined up, tie rods are bolted together-and the house is launched.

Walter Dorwin Teague, industrial designer and architect, says, "We have only to apply to home-building the same techniques of design, manufacture and selling that have given us a motor car for every four people in the land. Long experience with many of the largest mass-production industries has enabled me to design a house especially adapted to assembly-line methods of manufacture. The result is a house of charm and comfort which can surround you with conveniences amounting to luxury."

"Ah, but how about the cost of this modern home?" you may wonder.

Mr. Teague's answer is, "When a big manufacturer gets into mass-production, the cost of this house to you, delivered and erected on your prepared site, will be somewhere between $\$ 1,000$ and $\$ 2,000 . "$

\section{Standardization?}

Yes, the engineers and architects know how much you dislike standardization-and especially in connection with homes. They have worked out solutions for this dilemma too. The Norman Bel Geddes house, for example, has twenty-seven units. Each of these can be switched around like a set of building blocks, to form eleven different types of homes. If your lot has one outlook or exposure that is preferable to others, your house can be assembled as a long building with the important rooms and windows facing in that direction. Identical houses on adjacent lots will look entirely different if turned in other directions or assembled in other ways. Prefabricated houses have such novel features as movable walls that open a side of the house to the garden and that change 
the size and shape of the rooms to provide extra space or temporary sleeping quarters for an overnight guest. As Mr. Teague prophesies, "Your home of the future will probably look far less like your neighbor's than the one you live in now."

\section{The Circular House}

Henry Kaiser, the West-coast shipbuilder who broke all records by using prefabricated parts and assembly-line methods in his shipyards, has announced his intention to enter the prefabricated-housing industry when the war is over. Kaiser has retained the services of R. Buckminster Fuller, who has designed probably the most startling home of the future.

Here is Fuller's description of this home:

"Suppose you have bought or rented a building lot and have ordered one of these homes. The next morning a truck arrives and workmen begin unloading a lot of strange metal sheets and parts. Many of them look like giant flower petals. Others are large curved panels of corrugated metal. You notice flooring sections, bathroom and kitchen appliances, and a very small heating plant. And you see a structural steel contrivance that looks like a tall mast. It is, and it is used to support the house while it is being erected. For this house is built from the top down, and laying the foundation is one of the last things to be done!

"The mast is placed at the exact center of your house-tobe, and is anchored with guy wires so that it is firm as a rock. This takes only a few minutes. On the ground surrounding the mast, the petal-shaped metal sections are bolted together to form a round, domed roof with a hole in the center through which the mast projects. The completed roof is hoisted up the mast a few feet by a one-man winch, and curved wall panels are bolted on so that they hang from the roof. This 
process is repeated until the wall reaches its full height of nearly eight feet.

"Then the foundation is laid-a circle of bricks flat on the ground right under the circular wall. The house is now lowered so that the wall rests on the bricks, and the mast is then removed. A water- and bug-tight sectional steel floor is bolted to the lower rim of the wall, and all that remains is to install the sections of finished flooring, the lining, interior equipment, appliances and fixtures. The entire operation, from placing the mast to unloading your furniture from the moving van, takes only a few hours."

The steel sections of this house are enormously strong but very light. The entire house weighs little more than two tons -less than twice as much as your automobile. The house is round and there are two of these sections right against each other, a large and a small one. But Fuller says you'd get used to this. When you are in the spacious living room, he explains, you are hardly aware that it is round. A regular studio bed fits snugly against the wall. This is because the house is twenty feet in diameter, and a curve so large seems hardly to curve at all when you get close to it.

\section{Buy Your Home-Rent Your Land}

One of the developments certain to materialize with widespread use of prefabricated houses is the practice of renting land and moving the home from site to site according to the needs of the family. When the children are of school age the family would live in a district near a good school, paying a somewhat higher rent for their land in order to obtain the best school privileges. Later, when the children go off to college, the house could be moved to an area where the rent was lower. Renting land has been the custom for many years in some cities. 
"Why be tied to one place when your job or jobs may take you to different parts of the country?" asks architect Cass Gilbert, Jr. "Why own a lot and house you don't live in, and live in a house you don't own? Why not own a home you like that is different from your neighbor's, and rent the lot at the land rent only? In this way, you could buy the house on a credit-rent plan, rent the lot, own your home-and move it to your job."

Gilbert's answer is the Plank Panel house. Here is how it is built:

"Random width planks of dry, suitable lumber two inches thick and eight, ten or twelve feet long are run through machines that double tongue and groove the edges and rout out the ends. By modern methods of assembly, with modern glues, these planks are made into strong, solid panels four feet wide and eight, ten or twelve feet long. Each panel represents a four-foot width of wall or a four-foot width of floor. They are the 'building blocks' out of which the house is constructed.

"Provision is made within the body of each panel for internal metal rods to run horizontally through the wall at top and bottom, and also vertically at regular intervals. The rods pull all members together-roof, walls and floor-as tightly as bolts can hold wood. Window and door panels are manufactured the same way, are self-contained, and are an equally strong part of the structure.

"This then becomes a wall two inches thick that has been solidly pulled together by steel rods to steel corner members. These panels are so weather-tight that five of them could be bolted together by the same method to form a water tank. For each plank is not only double tongued and grooved, but is glued tightly to its neighbor with modern, waterproof glue. "With this house you can have exactly the style and appearance you wish. You also get a home which you can add to. Undo the corner bolts, add extension rods and a few panels, 
and you have an extra bedroom. If you have an unmarried son or daughter, build their rooms with extension rods so that when they marry they can take their rooms with them.

"The Plank Panels can be produced by any well equipped lumber mill. Under normal conditions the materials necessary are available locally in every community. And local workmen can erect the house according to a design that fits your needs, your taste, and your pocketbook."

\section{Tradition Takes a Back Seat}

For a great many generations it has been customary for a man to choose a house in which to live that resembled some style of house used extensively in some earlier period. He might ask the architect to modify the interior according to his personal needs and wishes. But these changes were usually minor ones. The whole process of making this selection of a home was based upon the assumption that the exterior must conform to a certain style and if any comfort at all were feasible on the inside, why, that was fine, but if not, the man and his family would adjust themselves to the house as gracefully as possible.

"Except for moving the bathroom inside, improving kitchen equipment and heating and lighting systems, our houses are much the same as they were hundreds of years ago," declared George Fred Keck, a disciple of the school of modern American architecture founded fifty years ago in Chicago by Louis Sullivan and Frank Lloyd Wright.

"Our houses have little checkerboards of glass for windows, because our forefathers couldn't buy a big piece of glass. Even though we now can have a whole wall of glass we don't because architects and builders have preferred to copy the old rather than create the new.

"Automobile makers," he points out, "weren't satisfied to 
go along copying the wagon. They produced an entirely new type vehicle. Why shouldn't we architects do the same instead of copying French châteaux, Spanish villas or antebellum mansions?"

Mr. Keck believes that houses should be designed to afford a maximum of comfort and convenience. In planning his houses he uses the sun's rays to aid in heating them. Thus the south wall of the house is made chiefly of glass. A wide flat roof overhangs the edge of the building to shade the glass wall.

"The object here," he explains, "is to shut out the intensely hot summer sun, as with an awning; and when the sun is low on the horizon in the winter, to admit the winter sun. In this manner one takes advantage of the sun in the wintertime when it is desirable to have the sun heat, and controls the hot summer sun. Such an arrangement will help heat the house in winter and keep it cooler in summer, and will make all the rooms in the house very pleasant places to be at any time."

This house is basementless with panel floor heat, which means that the floor is a moderately warm radiator which heats the house. Panel floor heat keeps the feet warm, and children rolling and playing on the floor will not be cold. In the coldest weather the floor can be kept at 80 to 90 degrees Fahrenheit and can provide comfortable room temperature.

The northern side of the house is almost a solid wall to provide utmost insulation against the wind and cold of winter. The projecting eave lines of the roof prevent blowing rains from entering any openings in the house.

The roof is flat, and strong enough to carry a thin sheet of water for summer cooling. The sun's rays cool the house by evaporation, just as they cool a swimmer in a wet bathing suit. This idea is an application of one used by the ancient 
Egyptians. They covered their roofs with a layer of wool and had slaves douse them with water in the hot sunshine.

Before designing any home, Keck carefully studies the particular requirements and habits of the occupants. A Missouri college professor liked to give large teas. Yet the family itself was small and normally required no large living room. Keck arranged the living, dining, and recreation rooms, all of modest size, in such a way that through the use of sliding walls the three rooms could be converted into one immense living room.

Keck believes that the rooms of a house should be arranged so that it can grow and adapt itself to the family's changing needs. The infants' nursery grows into the playroom of the grade-school boy and girl; then into the recreation room of the high-school youth; then into the private apartment of the young married couple, who may lack the finances to support a separate home; and finally into the suite for Grandpa and Grandma when the son and his bride have begun to rear a family and need more of the house.

"This sort of home," Keck says, "would preserve the distinct family units. It takes into consideration the changes that develop in a family through a lifetime. It combines structural permanence with perfect adaptability."

\section{Trading in Your Old Rooms}

Paul Nelson, an architect who has won fame throughout Europe and America, believes a new and more flexible design is needed for the prefabricated house. He envisions a house made up of two distinct elements-an exterior shell forming an enclosed space, and the prefabricated unit rooms which are grouped independently within.

"There would be rooms adapted to the needs of cooking, 
sleeping, washing and leisure. There could be rooms for hobbies, and special acoustical rooms for radio and television," he explains.

"The same evolution would surely occur with mass-produced rooms that occurred with the automobile. There would be the possibility of buying and selling second-hand rooms. This would bring these superior living units within the reach of even the lowest income groups.

'Similar rooms, called 'roomettes,' are now made for Pullman cars, their major elements stamped out by machine and quickly assembled into complete units. It is only a short step from this to the mass production of rooms for your own home.

"A truck could back up to your house and a complete sleeping room, bathing room, cooking room or eating room, for example, could be unloaded and set in place. The process would be almost as simple as plugging in the flexible copper connections of your present refrigerator or washing machine. With the most essential rooms installed, your home would be ready for living. Then you could plan for additional rooms to add extra pleasure and convenience to life. At your photographic dealer's you could select a dark room. You could find a special music room at your department or music store. If additional nursery or sleeping space were needed, the required rooms could be quickly installed. If the family became smaller, rooms no longer necessary could be sold, or 'traded in' on rooms for hobbies or whatever you might wish.

"By creating the bome in contrast to the house, by providing greater living convenience, comfort and enjoyment, by freeing the individual for richer cultural development, and by doing these things in a way which brings them down within reach of millions-this conception could provide better living for the present generation." 


\section{The Apartments of Tomorrow}

What about the more than 13 per cent of American families (about $4,000,000$ out of $30,000,000$ ) who live in apartments and may continue to do so? Architects and designers have not forgotten them. Apartments of tomorrow will provide more comfort and living space than ever before.

Elisabeth Coit, who is one of the few woman members of the American Institute of Architects, spent two years studying the good and bad in housing, and talking to tenants in low-cost apartments. She has given fellow architects a lot of excellent firsthand information on apartments from the tenant's viewpoint.

She pointed out that the trend in apartments is toward larger rooms. One survey showed that apartments with an average room area of 168 square feet proved very satisfactory, while one with an average of I $_{3}$ square feet was hard to rent.

"This to me," she said, "is a healthy development. I always urge clients to think of rooms not as boxes but as spaces for certain uses. A large space is easier to adapt to several purposes than a tiny one.

"But let's see," she added, "how average families use their homes, and whether the apartments are designed with such use in view. Families in small quarters, for example, need living rooms for callers, meals, quiet relaxation or emergency bedrooms. Yet most living rooms are chiefly runways for entrance to other rooms. They afford neither quiet nor privacy. "A living room should be planned so you can shut it off from other rooms when you want to. It should have a closet; and be separated from the kitchen. In fact, the living room might lend some space to the bedrooms. Rooms designed only for sleeping are a waste, for they are used only a few hours." 
Miss Coit would rename bedrooms "parents' room" and "children's room," and give them twenty-four hour usefulness. If Mother sews, there would be room for a machine. Boys need a place for gadgets. And the girl deserves room for a dressing table, and a desk and comfortable chair. The bedrooms could have some shelves and a few trays built into closets. This would eliminate the dressers, and you'd have more space and less furniture to dust under. Furthermore, built-in bunks are excellent for a boys' or a girls' room.

\section{Design Your Own Apartment}

Walter B. Sanders of Research and Planning Associates, New York City, has designed an apartment house of tomorrow that is similar to Paul Nelson's plan for a house made up of two distinct elements-the exterior shell and the prefabricated unit rooms.

Sanders suggests that apartment structures might be designed along the lines of loft buildings, consisting of just floors and ceilings. Space could be rented by the square foot, and the amount of standardized equipment could be left to the needs and means of the tenants.

"Imagine renting an apartment on the basis of the space needed," explained Sanders, "with exposures, amount and placement of windows, size, number and purpose of rooms and closets left to your own choice! The potential market for apartment owners would be vastly increased; strained landlord-tenant relationship greatly improved."

The apartment building could consist of two distinct elements. First there would be the structural frame, including floors and ceilings. Within this would be created the individual apartments using mass-produced, standardized wall and partition units. The necessary electric conduits, water-supply and drainage mains, would be in place and there would be 


\section{A Castle for Every Man}

fittings at each floor level to allow connections to individual apartments.

You could step into your rented space and then arrange your apartment to suit yourself. The outside walls could be clear, translucent, or insulated opaque units. You could move them inward in the summer to form private outdoor terraces and to shade the interior from the sun's rays. In the winter you could move the walls forward to permit maximum sunlight to enter your apartment.

The exterior wall sections would be part of the building assembly. But the partition sections could be either purchased or rented from the owner. Closet and wardrobe units, obtained the same way, could be used as partitions to divide the space in your apartment. These easily arranged, prefabricated units would give your apartment great flexibility. It could be altered as family conditions, or your moods, changed. That "ole devil" standardization would not bother you.

Finished floorings also would come in sections that could be quickly put down. The plumbing fixtures, bathtub, toilet, lavatory, kitchen sink, and other units might be either rented or owned like your furniture.

"The tenant's investment in parts purchased by him," explains Sanders, "would always have a trade-in value, just as with vacuum cleaners, refrigerators and radios. If necessary for any reason to move to another location, similar apartments could accommodate the parts you owned. And if moving into a home instead of an apartment, the incorporation of this equipment would absorb in long-term buying some of the financial shock of home building and ownership."

Sanders likewise points out that owners, as well as tenants, would share the benefits of the new apartments of tomorrow:

"The initial building investment would be minimized, since the purchase of the standardized parts would be according to 
tenants' demands. Demountability of the structure would permit either renting or buying the land for assembly of the unit. The perennial 5 per cent allowance for vacancies would be decreased because available space could be transformed to meet the market. Replacement of obsolete equipment would be facilitated since it would be independent of the structure. The demountability and rented-land features could combat the tendency toward obsolescence due to crowding, deterioration of surroundings, or moving of production centers. With costs written off over a definite but different period of time for the structural frame, the equipment, the walls and partition sections, etc., depreciation rates could be determined more accurately, replacements facilitated, and the obsolescence of the entire building could be reduced due to the obsolescence of only a few of its parts."

\section{Problems Abead}

Warborn advances in building materials and construction methods will make possible a prefabricated home priced within reach of the average family. But, first, the war must be won so that our resources again will be available for home building. Second, the pressure of public demand for prefabricated homes must be strong enough to sweep away the old, out-of-date technique of building homes. These new homes cannot be built only one at a time. Standardization of parts and quantity production are needed to produce low-cost but well-built homes for millions of average families. If the building industry can be sure of a public demand for these houses, you can be sure that they will be produced. Mass production plus mass demand developed our great automobile industry and several others. It can also revolutionize the building industry.

A word of warning is voiced, however, by Arthur C. 


\section{$A$ Castle for Every Man}

Holden, prominent architect and a Fellow of the American Institute of Architects:

"Even a willing public will fail to get the benefit of the improvements that may be possible [in home construction] if it is ignorant and complacent. In all of our large cities and many of our small towns, laws have been passed to protect the public safety and health against abuses in the design and construction of buildings. But suppose a well-meaning building code reads something like this: "All exterior walls shall be a minimum of $8^{\prime \prime}$ of masonry construction. . . . All interior wall surfaces, except where panelled in wood, shall be of plaster or tile. . . . All floors in bathrooms shall be of approved masonry construction.' These are phrases taken out of typical building codes; they have the effect of preventing innovations and improvements within the limits which are 'protected' by such restrictive codes."

In order to economize particularly in plumbing materials, the Federal Government drew up a compromise building code, which many cities and towns agreed to follow during the war emergency. But they may return to more restrictive codes when the war ends, unless the public demands a realistic policy toward prefabricated building materials.

In its 1943 report on a postwar economic program and social security plans, the National Resources Planning Board urged the modernization of building codes and recognition of the value of modern refinements and improvements in construction materials and methods.

There is danger likewise that life-insurance companies, savings banks, and building and loan associations that lend money on mortgages may be allergic to machine-made houses. These institutions naturally seek to guard their investments by turning thumbs down on the use of building materials that have not been thoroughly tested. But this caution must not be permitted to block the use of the excellent new materials 
(light metals, plywood, plastics, etc.) which have been developed in the past two years.

The premium payers and depositors in lending institutions, who also happen to be among those who will benefit from low-cost, prefabricated houses, should insist that these institutions keep an open mind on the subject of prefabrication. There'll be some amazing changes made in the postwar world. But changes in homes will affect the largest number of people in their everyday lives-if prefabrication is given the proper environment. 


\section{III}

\section{LITTLE MIRACLES}

"WHY CAN'T OUR HOMEs be as comfortable as the dustless, draftless, air-conditioned, soundproofed, and almost perfectly lighted war plants now in operation?" some of us have been wondering.

Despite our twentieth-century realism and scientific advances, the average home possesses few comforts. Suffocatingly hot in summer, drafty and unevenly heated in winter, badly lighted at all seasons, cluttered with too much furniture and equipped with old-fashioned appliances that function poorly or not at all, our homes reflect few of the engineering and designing achievements of our generation. Our ten-year depression and the exigencies of a wartime era were chiefly responsible for this lag. But the necessity of maintaining high employment levels after the war may bring about the mass production of many household appliances and devices that we now regard as luxuries. In this case we shall be able to purchase for modest sums many important aids to better living.

\section{Modern Ligbting Equipment}

Perhaps no improvement would mean more to most of us than better light at home. Chronic eyestrain plagues millions of Americans. This problem cannot be solved by increasing the concentrated light supplied by floor and table lamps. The contrast with the dark room beyond the circle of bright light would merely aggravate the condition. The whole room should be brightened up by a combination of fluorescent and 
incandescent lamps mounted in a cove near the ceiling. Lighting could be automatic and governed by electric "eyes" sensitive to outside variations in the daylight.

Because they produce a rich glowing light that is cool, fluorescent lamps should be used on desks and tables. They are more efficient and cost less to operate than the incandescent lamp. The fluorescent lamp consists of a long thin glass tube containing mercury. It is coated on the inside with a substance (phosphors) that fluoresces, or gives off light when exposed to ultraviolet radiations. The light from the fluorescent lamp is nearly as white as daylight. You can't see ultraviolet rays, but you can observe their handiwork. One type of ultraviolet radiation from the sun produces sunburn. These rays also help your body to produce Vitamin D.

If the coating of phospors is not put on the fluorescent lamp and a special glass is used for the tube, it then gives off powerful germ-killing ultraviolet rays which will keep your home free of harmful bacteria.

\section{"Laundering" the Air}

In the future your air-conditioning unit will also include a Precipitron to eliminate dust from your home. This device for "laundering" the air was invented in 1934 by Gaylord W. Penney of the Westinghouse Research Laboratories. It consists of tungsten wires and steel plates through which the air is drawn. The wires positively charge the dust particles, which pass on and stick to the negatively charged steel plates just as iron fillings are drawn to a magnet.

Penney reported that the Precipitron installed in his Pittsburgh home added only sixty cents to one dollar to his monthly light bill. He expected the cost of operation to be lowered by the development of more efficient equipment.

The curtains in Mr. Penney's Precipitron-equipped home 
stay clean for eight or ten weeks. But in pre-Precipitron days the curtains had to be laundered every two or three weeks. Walls that had to be washed every spring now stay clean for three years or more. This means that paint will last longer, and the savings in laundry and dry-cleaning bills also add up to quite a sum.

However, the air leakage into the average house is far greater than most of us realize. Penney says that the air in most houses will be changed from one to two times per hour due to normal leakage around doors, windows, flooring. This will limit the efficiency of the Precipitron and any air-conditioning unit. But the performance of Penney's "air laundry" in Pittsburgh's famous smog (smoke plus fog) proves that it is more than just another interesting gadget. After the war it is possible that Precipitrons may cost little if any more than electric refrigerators. Westinghouse has already made a unit that sells for three hundred dollars, and one hundred and fifty of them have been installed in private homes. The company reports that, with large-scale distribution later on, the price will be considerably lowered.

\section{Smokeless Furnaces}

Another victory over city dirt (as well as over the high cost of heating homes) has been won by Julian R. Fellows, professor of mechanical engineering, and J. C. Miles, associate, of the University of Illinois. They have developed a furnace of the future to burn soft coal without filling the air with smoke or soot.

More than 90 per cent of all the smoke produced by even the most volatile of soft coals is consumed by the furnace, which makes it possible to reduce fuel consumption by as much as 25 per cent and to use cheaper grades of coal. Smoke is forced down through the fire, where it is burned. Only the 
smokeless burned gases escape up the chimney. Models of the furnace (minus smokestack) have been operated in Urbana and Springfield, Illinois, hotel lobbies to demonstrate their smokeless performance.

Southern Illinois and other soft-coal interests hope the furnace will help them regain markets lost in past years as the result of antismoke ordinances in many cities, including oncesmoky St. Louis. Professor Fellows believes his furnace will appeal to many homeowners who cannot afford stokers and yet wish low-cost, smokeless coal heat.

\section{Soundproofing}

Noise is definitely harmful to one's nerves, and there is too much of it in the average home. Sound-absorbing material, which traps sound in thousands of small holes and keeps it from bouncing around a room, should be used extensively in the home of tomorrow. There is no reason why the clatter from the kitchen, or the uproar of the playroom, should be allowed to invade the living room. And a telephone nook, or a corner for reading or writing, could be protected from noises in other parts of the living room-that center of many activities of the average family. The new, open-front telephone booths in New York City's Sixth Avenue Subway are an outstanding example of effective soundproofing. A person can phone even while a train is rumbling by.

\section{Proper Acoustics}

The Architectural Forum goes another step forward and says that acoustics should not stop at the mere absorption of a sound. "It seems likely," the Forum declares, "that the designer of the house of the future will have to be as much concerned with rooms that 'sound' and 'feel' right as with appear- 
ance and convenience. The movie industry, for instance, has developed small rooms for screening pictures which sound exactly like big theatres. Is there any reason why the room in which we listen to the radio should not be made to sound like a concert hall when we listen to 'big' music? Modern rooms, with their bare walls and sparse furniture, often sound hollow-like an empty apartment-and frequently present other annoying acoustical problems. Most of these faults can be obviated by nonparallel walls, sloping ceiling or curved surfaces if the designer is sufficiently well acquainted with acoustical correction."

\section{Radiant Heating}

Engineers tell us that radiant heating will chase the radiators or hot-air vents out of the home of the future. Radiant heating warms the walls, or floor and ceiling, by means of concealed hot-air or hot-water pipes. The temperature in a radiant-heated room might be 65 degrees or less, but you could sit around in your shirt sleeves and feel comfortable. Sounds like "black magic." But it isn't.

Physics teachers tell us of a law which says that a warm body always loses heat to a cold one. Your body produces more heat than it needs, and you must get rid of this extra heat to be comfortable. You feel uncomfortably warm when the body has difficulty getting rid of its excess heat, and cold when it loses heat too fast. If the walls of a room are cold you lose heat to them and feel chilly even though the air in the room may be hot. But if the walls around you are heated by steam pipes to 80 or 90 degrees you lose very little heat to them and feel comfortably warm even though cold air may be swirling around you.

On the other hand, a radiator in a room heats the air in one spot and depends on the circulation to warm the whole room. 
This causes drafts and the room temperature is never even.

You have seen movies of bathing beauties out skiing when the temperature was below freezing. Were they running the risk of getting pneumonia? No-radiant heat kept them warm. The rays of the sun, which were reflected from the snow, balanced the body heat lost to the cold air.

Radiant cooling of a home works on the same principle as radiant heating. You would pump air or cold water through pipes and let your body radiate heat to the walls. But in most climates a dehumidifier would be needed to take the moisture out of the air, or the damp air would condense on the walls and turn them into miniature waterfalls.

\section{Built-in Furniture}

You'll have fewer pieces of furniture to move around on house-cleaning day in the future because more pieces will be built into the house. The industrial designer Gilbert Rohde believes that all "wall pieces"-chests, cabinets, anything that now remains in position against the wall-will be built in as part of the house.

"The building-in of furniture," he explains, "will relieve a family of bulky possessions, will be cheaper; and will permit a better organization of space because the furniture will be built to fit. Large sofas may also be built in with radio and radio-television controls in the arms."

T. H. Robsjohn-Gibbings looks forward to the day of fewer and better pieces of furniture. He feels that "man's psychological fear of an empty space" has caused him to clutter up his home with unnecessary furniture. He contends that the first part of our adjustment to the house of tomorrow must be to overcome this instinct to fill empty spaces. Then 
all the furniture which is placed against the wall for the sake of filling an empty space will be eliminated.

"All the money," he concludes, "which we have spent because of this pathological fear will then be available for the furniture we need for actual use in our rooms. And we can concentrate on making this furniture beautiful, or finer quality, and available to all."

Robsjohn-Gibbings adds the prediction that the men in the airplane industry, who are making amazing experiments in wood fabrication, may have an important influence on the furniture industry of the future.

\section{Mass-Produced Closets}

One long-standing complaint of housewives has been the lack of good storage space. They want more coat closets, bedroom closets, linen closets, toy closets, and so on. The usual skimpy closet could be expanded into a dressing room with specialized drawers and shelves for protecting and storing clothing. Designers are planning new mass-produced closets to give maximum service at a low price. These closets will have raised floors and rounded corners for easier cleaning, built-in lights, mothproof linings, built-in drawers, and a variety of hangers and racks for trousers, shoes, ties, coats, and hats. A few of these closets could easily turn an ordinary house into a good one.

\section{Small Items That Mean Comfort}

Plastics, which are made of air, water, coal, and limestone, will be used for interior decoration in your home. Window molding, doorknobs, mantels, and other trim made of bright, colorful plastics will make your home more cheerful. Lucite, 
one of the new plastics, can make light rays go around a corner. Thus it will be possible to bring sunlight from the roof down to any room in your house. Among the other synthetics are fabrics, woven from glass, which will make draperies and curtains that are fireproof, unfading, and practically everlasting.

Russel and Mary Wright are confident that "increased experience with synthetic fibers will produce simplification of the labor-wasting system of bedmaking. Imagine a buttonless mattress to which is attached a permanent blanket containing a highly efficient insulating material-both mattress and blanket covered with a new scrubbable fabric, leaving only the sheets and pillow cases to be washed," they explain. "Improved electric blankets equipped with thermostatic adjustment to suit the fussiest sleeper may well become household staples."

\section{A Modern Bathroom}

The average bathroom has not been improved much since the 1920 's. The shower should automatically deliver water of the right temperature, instead of generally requiring several minutes of experimenting. Built-in soap dishes should drain properly and prevent soap from turning into a sticky mess. Instead of spilling several articles out every time it is opened, the too-shallow bathroom cabinet should be deep enough to hold the large assortment of articles usually found in such a cabinet.

Discussing apartment-house bathrooms, Elisabeth Coit remarks, "How many designers are guilty of putting bathroom cabinets back to back with no insulation between? The neighbor's conversation and his plumbing noise come right through!"

The mirror over the washbasin should be well lighted and 
adjustable so a man could shave himself without courting eyestrain or razor nicks. Knee levers or toe pedals should open and close the taps in the washbasin. And why not make the basin big enough to bathe the baby in? Walter Dorwin Teague suggests putting an electric washing machine under the washbasin. Of course you may prefer the laundry equipment in the kitchen. But since every woman uses the bathroom for laundering stockings and lingerie, some designers say the whole laundry might just as well be done there.

Electric heaters and sun lamps should be built into the bathroom ceiling. A waterproofed rubber-tile floor would permit a person to walk around barefooted without getting cold feet.

"The mass-production techniques that made the auto what it is today," observes Fortune magazine, "may make the bathroom what it should be tomorrow. Small bathrooms could be made in a few easy-to-assemble pieces, priced to undersell even the cheapest home-installed jobs. The eminently sensible Victorian custom of a lavatory in each bedroom might be revived-and improved-with devices like the disappearing washbasin of the Pullman bedroom. Large bathrooms could include an array of refinements and innovations. The largest might include dressing rooms equipped with everything from curling irons to overnight pants pressers. Such units could replace many an existing bathroom. With his 20-year-old fixtures giving him trouble both esthetically and functionally, what house owner could resist the temptation to rip them out and put a $\$ 700$ dream in their place?"

\section{Refrigerator Drawers}

The prewar refrigerator was a great improvement over the old-fashioned icebox. It kept food colder. But a lot of that "cold" was lost every time you opened the refrigerator door and rummaged around hunting for something invariably be- 
hind two other bottles or dishes. A lot of dispositions were ruined by balky ice-cube trays.

The refrigerator of the future could be divided into a series of drawers spread out along the kitchen counter. Each drawer would hold a certain kind of food at its own ideal temperature and humidity. There would be a drawer for milk, butter, and cheese; another for frozen foods; another for meats; and another for vegetables. Glass tops in the kitchen counter would permit you to see the contents of a drawer without opening it. Ice cubes might be obtained by pressing a button or turning a crank.

\section{The Hamby "Kitchenless House"}

The basis of William Hamby's work is that the home must be improved for the one who uses it the most-the housewife. To get rid of kitchen drudgery, he has abolished the usual kitchen. He's streamlined the kitchen and brought it out in the open so that it becomes part of the spacious dining area. It forms the end wall of the dining room. No longer would the kitchen be a room shut off from the rest of the house, where a woman "stands over a hot stove," wears herself out stooping and stretching to get things out of cupboards or the refrigerator, and keeps busy early and late washing dishes.

"Don't think for a minute," Hamby hastens to add, "that this arrangement handicaps the kitchen by restricting it to makeshift methods-or that it spoils the dining room by littering it with pots and pans. This is an entirely new kind of kitchen, with far more facilities of every sort than the low-cost home has ever had before. And, like nearly all things that work better, it looks better, too."

When you enter the Hamby "kitchen" you immediately notice the long horizontal arrangement of counter, sink, and cupboard space. All the staples and heavy utensils are on the 
shelves easiest to reach-no more teetering around on a stepladder while you hunt for an elusive box of cloves or baking powder. The lighter dishes and plates are on the shelves immediately above. The whole length of the kitchen counter is designed for food storage, with compartments to hold each food at its own ideal temperature and humidity, including vegetables, meat, butter, frosted foods, and cereals.

This kitchen has an easy-to-reach place for everything, and everything is in its place. You can prepare an entire recipe at one spot, without stooping, stretching, or hunting for things. Suppose you take a chicken from one of the kitchen-counter compartments. Right at hand you find all the materials for stuffing the chicken, roasting it, and making the gravy. Then you serve it at the dining table only a step or two away. No, you don't serve it on a special platter. You serve it in the same utensil it was cooked in, for it is a bright, clean electric utensil that plugs in along the kitchen counter.

Automatic heat regulation makes these utensils ideal for cooking a meal. No longer do you have to patrol the kitchen looking at each pot and pan to see that something is not getting ready to burn. No more do you worry about whether the beans and corn are going to be done too soon, and will have to stand around while you fix the steak or chops. Automatic heat control will see that each vegetable or meat dish is done at the right moment to serve piping hot-thus removing a major cause of worry for the cook.

By this time you've also noted that the kitchen needs no stove. That's another place where cleaning and scouring would be abolished. You get another pleasant surprise when you examine the sink. Instead of bothersome hand faucets, there are knee-operated valves that leave both hands free. And a waterproof paper bag, in a compartment built into the sink, does away with the unattractive garbage pail. 
At one end of the kitchen counter you discover another device to eliminate "Monday-morning blues"-it's a modern automatic laundry. The laundry is concealed from the dining area but is really part of the kitchen.

You note, too, that the kitchen is flooded with light in the daytime, but it is not too bright for your eyes. The kitchen wall itself is of translucent fiber glass, while the wall units cut off the light at eye level and keep you from having to look into the light. Fluorescent tubes along the walls provide inexpensive, cool "daylight" at night. In the center is an open space of transparent glass to serve as a window-with-view, and in this are placed glass shelves for plants and flowers.

An oil-burning fireplace furnace to heat the house and furnish year-round hot water is recessed into the living-room wall next to the kitchen. You can open the door to let the comforting oil flame of the furnace show through the glass in front-all the atmosphere of the wood-burning fireplace without its bother.

Hamby points out that this arrangement not only simplifies the heating system but concentrates all the mechanical working parts of a house near one point. "This would enable you," he explains, "to get the most out of the plumbing, wiring and utilities. In that way, and through the use of rust-proof copper pipes and parts, leaks and costly repairs could be almost permanently eliminated."

In this two-story house the bath is immediately above the kitchen and utilities. This location further concentrates the mechanical parts near one point in the house. By reducing the length and complication of the piping, such a plan makes it possible to use the finest plumbing methods and the best materials while keeping the over-all cost within the reach of families of moderate means.

Because every inch of space in this "kitchenless house" is planned for full use, this home can be of modest proportions 
and still provide plenty of living and working space for the family of average size.

This reduction in size, plus the simplification of mechanical parts so they can be mass-produced, should make Hamby's house cost no more than thirty-five hundred dollars complete with all its improvements. 


\section{IV \\ CARS OF THE 1960's}

Your POSTWAR CAR will probably be made of light metals and plastics and may therefore be around one thousand to twelve hundred pounds lighter than 1942 models! This means a smaller, "air-minded" motor designed to burn the high-octane gasoline now used in fighters and bombers. You won't have to bother with the gearshift at all, for the gears will be shifted automatically as your car picks up speed. There will be no fenders nor running boards on this "wingless plane-car." The wheels will be enclosed by the streamlined body and the bottom of the car will be airtight to protect the drive shaft, differential, and other parts from dust and dirt. Doors will slide back or roll up like a roll-top desk and will be controlled by buttons instead of door handles!

Yes, this new car will be more livable and practical than any you have been able to buy to date. Removing the fenders and running boards will permit the inside of your car to be more spacious, without greatly increasing its over-all length. This will provide a back seat at least six feet wide, giving space for a couch or bed. The driver's seat will be fixed (but adjustable, of course), while the other two front seats may be moved around as you move your living-room chairs. And there will be plenty of "living room" in your new car. Upholstery will be of a fabric made of soy beans, or a cloth spun from glass. These can be easily cleaned with a damp cloth. The inside of the car will not be cluttered up with window cranks, because the vehicle will be air-conditioned. 
Visibility for the driver will be increased by having his seat far forward. Only about 25 per cent of the total length of the car will be in front of his line of vision, instead of 50 per cent as in 1942 cars. This will enable the driver quickly to spot cars coming in from cross streets and eliminate a lot of nerveracking sharp turns and quick stops.

Your car's tough, transparent plastic nose, like the "greenhouses" on a Flying Fortress, will give you unbroken vision all around. No more peeping from behind the center or corner posts in the windshield. This plastic nose will not fog or frost -it would not be used by our high-flying, all-weather bombers if it did.

Headlights could be made to throw a narrow, flat beam to illuminate the road ahead without blinding an approaching driver. Or a polarizing lens for headlights, plus a similar screen for the windshield, would abolish glare. A lens of this type is already widely used in our glare-eliminating sunglasses.

Your car may have rubber springs, which also serve as shock absorbers. They will operate silently and reduce road noise. Easier parking and steering will be obtained by having somewhat smaller wheels. But the tires may be larger, using lower air pressure to give you smoother and longer service. Rayon cord fabric makes military tires stronger. Your postwar tires will be made of long-wearing synthetic rubber (mixed with small amounts of natural rubber) and rayon cord. You should get around one hundred thousand miles of wear from these tires. A very tough, heat-resisting glass-textile fiber may prove suitable for tire cord. If this fiber can be used, it will be possible to reduce the amount of rubber in tires.

A plastic "sky-view" top will give everybody in your car a chance to enjoy the scenery as you explore new sections of the country. Industrial designer George Walker explains that the plastic top will permit the transmission of ultraviolet rays (which are halted by ordinary glass) and "will give the pas- 
senger a good tan without the discomfort of sunburn, due to the elimination of the infrared rays." A lightweight Venetiantype blind could control the amount of light desired, or a polarizing device could be adjusted to shade off excessive sunlight or glare. The plastic top also would insulate the car against summer heat and winter cold.

An air-conditioning system will permit you to take your climate with you no matter whether you are touring a desert wasteland or the icy mountains. The air conditioner is located under the snub-nosed hood in front of the driver-the engine doesn't live there any more. It is in the rear, installed in "pancake" fashion (with the cylinders horizontal). The engine is directly over the rear wheels, which permits the hooking of the engine directly to the transmission system. This arrangement reduces the loss in power resulting from the use of a long drive shaft running from the front to the rear of today's car.

The removal of the drive shaft makes it possible to lower the floor of the car, thus putting the center of gravity so low that on sharp turns at high speeds the car banks and doesn't roll easily. You have seen this principle demonstrated by a toy doll with a weighted base, which keeps it from being knocked over. One airplane feature-vertical fins like plane rudders-may be used by some postwar cars to give them greater "roadability." (One of Packard's designs for a postwar car uses this idea.)

\section{New Low Prices}

You will get all this and more safety, too, at a low price and an operation cost little higher than that of your household appliances.

How much will your postwar car cost? Some engineers say a light car can be made to sell for around seven hundred dol- 
lars, a little less than the same size prewar car. Others believe that a car can be made to sell for four hundred dollars.

"After a few years," remarks David Dietz, Scripps-Howard science editor, "post-war cars will be so far ahead of 1942 models that the differences separating the two will be greater than those separating the 1942 car from the old Model T Ford."

Dr. Charles M. A. Stine, vice-president of E. I. du Pont de Nemours and Company, points out that "since automobile production stopped the shiny new models that are gathering dust in dealers' storerooms have aged, technically, at least 20 years. We are now in the 1960's of motor cars, as measured by the old pace of development."

Between 1912 and 1942 the automobile industry did give the consumer a car of greater dependability and better appearance at a lower cost. In dollars per horsepower, cars cost only about one-third what they did in 1925. And it cost the owner a little more than half as much to run his car in 1942 as it did fifteen years ago!

But in recent years the more the prewar car seemed to change the more it remained the same. The main reason for this was the huge investment in expensive dies and tools which the companies did not want to scrap. A new model was brought out each year, but this model did not differ more than ro per cent from the previous year's model.

Automobile stylists designed a car with accent on beauty. They went in for fancy fenders and radiator grilles. They streamlined the windshield by slanting it, but they also streamlined the rear window so that in winter snow piled on it and the driver couldn't see out. Even in clear weather the rear window gave the driver little more vision than that afforded by the tank driver's slit in an M-4 tank. Meanwhile the automotive engineers were forced to wrench the machinery around to fit the stylists' ideas of what a car should look like. 
In $194^{2}$, however, the automobile industry was converted to war production. While setting records in the output of tanks, guns, planes, and other equipment for war, the automobile industry has learned a lot about using light metals, plastics, compact engines, and new fuels for postwar automobiles. Furthermore, the old automobile assembly lines have been torn out to make way for war production; some tools and dies have been scrapped, or are getting out of date.

Figuratively rubbing his hands, Fred M. Zeder, chief engineer and vice-chairman of the board of Chrysler Corporation, declares:

"As a result of the suspension of automobile production, the industry will find itself for the first time, when the war is over, able to approach the design and construction of motorcars on a new basis. The war has freed motorcar engineers from the traditions of the past, freed them from the stranglehold of old machine tools and methods. Research can now be directed at things as they should be, rather than as they are."

\section{Engines Move Back}

Needless to say, all of the new possibilities for the car of the future will not be adopted without a struggle. The pros and cons on rear engines are being argued fiercely now and, to be sure, you will be able to buy cars in the future with engines up in front. Some engineers still favor that arrangement. They contend that a rear-engined car will be difficult to control at high speeds and that a constant weight on the front wheels makes for a smoother ride. They also point out that the necessity of keeping the engine cool requires that it be up front so the radiator can get the benefit of natural draft.

Proponents of the rear-engined car say the weight prob- 
lem will be solved by the building of lighter engines. William "Bill" Stout says the rear-engined car can be cooled efficiently if the motor is installed lengthwise instead of sidewise. His rear-engined Scarab, which was built in 1935, used a Ford V-8 motor, with cooling solution sealed in, and ventilation vanes built into the engine housing. A "pancake" motor could be cooled by bringing the air down from a grille in front of the car and passing it to the motor through a tube running under the floor. Some critics of rear-engine installation agree that if a compact air-cooled engine is generally adopted it could be placed anywhere.

Mr. Stout reminds us that the first cars had their engines in the rear; but the manufacturers abandoned the idea because they could not drop the notion, says Stout, that a car was really a buggy, with an engine instead of a horse between the shafts.

Stout insists that the rear-engine car is safer, having less tendency to skid because the additional weight gives the rear tires a better grip on the road than does today's front-engined car. "Even on ice," he adds, "I find it easy to maintain traction in this car-the Scarab-which I have driven 125,000 miles. With the weight in back, the rear seat ride will be the best ride in the car. In front-engined cars the best ride is given the engine, and the passengers take the bumps. ... At the same time, the front end is light enough so that if you run off the slab onto soft spots beside the highway there will be no tendency for the front wheels to bury themselves in the mud and put the car out of control."

Engineers may continue to argue over where the engine should be placed. But they all agree that it should be improved. "The present engine," declares Fred M. Zeder, "weighs five times as much per horsepower as the aviation engine. . . . We can go as far as we want in weight reduction of automobile engines. In fact, it's possible to eliminate 250 of the 
average of 600 pounds." "Bill" Stout already has developed a hundred-pound, hundred-horsepower, four-cylinder, aircooled automobile engine.

\section{New Metals for Nerw Motors}

New light but tough metals and more powerful gasoline will aid in the perfecting of small, high-speed auto engines with greater power per pound of weight. If a little gasoline is poured on the ground and ignited, it flares up quietly. But if gasoline and air are compressed by the piston in the cylinder of an engine, and then ignited by a spark, the mixture burns very rapidly and the consequent expansion drives the piston back with great force. The more the gasoline and air are compressed the greater the power delivered. The problem has been to make a cylinder head strong enough to stand the greater pressure exerted by a high-compression motor, without adding too much dead weight to the motor.

The use of steel alloys (steel plus vanadium, chromium, molybdenum, manganese, etc.) and beryllium has produced materials which make light but tremendously strong cylinder heads. Further experimentation with beryllium, the tough cousin of aluminum and magnesium, promises to bring future marvels in metallurgy to speed the building of the low-cost postwar automobile.

Beryllium is one-third lighter than aluminum and harder then steel, but it is too brittle alone for use in high-speed machinery. If 2 per cent of beryllium is added to copper, and a heat treatment then is used, an amazing change is wrought in copper. The beryllium-copper alloy made into a rod only one-half inch thick will lift twenty tons! A beryllium copper chisel can be driven through steel. Most metals "get tired," but beryllium-copper is virtually untiring. It gets a "second wind" just when other metals give up the race. For instance, 
spring steel will take three million vibrations on a testing machine. Beryllium-copper can take at least one billion.

The delicate new aviation instruments have berylliumcopper in them to assure permanent accuracy under all sorts of stress and strain. Engineers have begun to use this alloy in the electrical equipment, valves, and gears of engines, and in radios, electric motors, and other high-speed machines. Your vacuum cleaner and refrigerator give you longer service because of beryllium-copper.

Another alloy-beryllium-nickel-is stronger than beryllium-copper and has a bright future. If beryllium and aluminum can be combined, the automobile and aviation industries may have the perfect alloy for engine pistons. And when the problem of combining beryllium and magnesium is solved, engineers will have an excellent alloy for structural purposes.

As beryllium-production processes are simplified, and the price is lowered, this metal will be used more widely in the building of a better postwar auto engine.

\section{Renaissance of the Diesels}

Recent improvements in Diesel engines indicate that the present gasoline motor may someday have to look to its laurels. The Navy is using a new "pancake"-type Diesel engine which gives lighter ships increased speed and range.

Dr. Rudolph Diesel, a German engineer, patented his engine in 1892 and first operated it successfully in 1897 . The power explosion in the Diesel cylinder is caused by compression instead of by a spark as in a gasoline engine.

Thus the Diesel has no ignition system nor spark plugs. Neither does it have a carburetor, which is used in the gasoline engine to mix air and gasoline and admit them to the cylinder. In place of the ignition system and carburetor there are injectors, which are usually placed about where the spark 
plugs would be in a gasoline engine, and the injection pumps.

The Diesel's piston compresses the air in the cylinder and raises the temperature to about I,ooo degrees Fahrenheit. (You may remember how a bicycle pump gets hot while you are pumping up a tire.) When the piston is near the top of the cylinder, fuel is injected into the heated air in the form of a fine spray; and it starts to burn immediately. The burning fuel then expands rapidly and forces the piston down.

The best gasoline engines must use high-octane fuel, and others generally use ordinary gasoline. But the Diesel will use any fuel-gaseous, liquid, or solid-igniting at r,00o degrees Fahrenheit or under that can be sprayed into the cylinder. Usually the Diesel burns heavy fuel oil. Diesel's first, engine used powdered coal, and even buttermilk has been used. The Diesel is not choosy!

Aside from the fuel-economy angle, the Diesel is the most efficient of all types of heat engines. The steam engine is 6 to 8 per cent efficient; the steam-power plant, i 5 to 27 per cent; the gasoline engine, 22 to 28 per cent; the Diesel, 32 to $3^{8}$ per cent. The temperature of the Diesel never is as high as that of the gasoline engine. High cylinder temperatures are always transmitted to the surrounding air or cooling water, and are carried off as waste energy. Therefore the Diesel wastes less energy in this manner than the gasoline engine-one of the main reasons why it is more efficient.

Charles F. Kettering, research chief of General Motors, believes the Diesel is ready to go places after having experienced plenty of growing pains.

"In old days," he said, "Diesels were large and terribly heavy. They used to say a Diesel was 'a mountain of iron with a rivulet of power.' Also, it made a lot of noise and a bad smell. One trouble was that for the first 20 years, because they put Diesels in boats, they tried to make them like gaso- 
line engines. Now, we are trying to make them like Diesel engines. So, with constantly better alloys and knowledge of combustion, we are steadily taking metal, and noise, and smell out of the Diesel."

In 1937 Kettering declared that "the Diesel is entering new fields of usefulness entirely unsuspected just a few short years ago." Today the Diesel seems headed for still newer fields.

Recently it was discovered that when ordinary gasoline was used as a fuel in the Diesel it gave one-third more miles per gallon than the same fuel would have given in a gasoline engine. This discovery may lead to the adoption of a fuelinjection gasoline engine, without spark plugs or carburetor, which operates on the Diesel principle. Excellent German aviation engines use the fuel-injection system and give plenty of power with gasoline which has a much lower octane rating than our new fuels. So here is another possibility for the superefficient postwar auto engine.

\section{Jeeps for the Farm}

When they stop to think about postwar cars, engineers give some attention to the jeep's character and performance. This $\mathbf{2 , 2 0 0}$ pound combat car can carry six men in an emergency, mount a fifty-caliber machine gun, and tow guns and other equipment. There are few jobs in the Army that it hasn't been asked to do and it does them well.

It is powered by a four-cylinder, sixty-horsepower, go-devil engine and has six speeds forward and two in reverse. It can plow through high water, duck in and out of ditches, dodge under trees, and scramble up steep hills while its crew is pumping lead at the enemy.

The American Bantam Car Company came forward with an idea for a jeep in 1940, and the Army promptly dropped its plan to buy a lot of motorcycles. Willys-Overland, Bantam, 
and Ford now make jeeps for the Army, which considers them our main contribution to mobile warfare. The Russians, who know a thing or two about fighting in all sorts of weather, agree that the jeep is no "summer soldier."

No one proposes that the jeep replace the passenger automobile, but Don E. Weaver, editor of the Fort Worth Press, believes the jeep will be kept busy when the war ends.

"After the Civil War," he wrote, "the slogan was ' 40 acres and a mule.' Well, why not 40 acres and a jeep? The Department of Agriculture has tried them out and finds that they can pull a plow, cultivator, or mower as well as a tractor. And you can unhitch the plow, load up the wife and kids, and go to town in the jeep on Saturday nights.

"The farmer lost the old family horse when he got a flivver and a tractor. The flivver couldn't work the fields and he couldn't go to town in the tractor. The jeep, bless its heart, can do both.

"If you're not interested in farming 40 acres with a jeep, or in using one to herd cattle or ride fences on your ranch, maybe you would like to take a two-week vacation roughing it. The modern auto is swell, but it can't be everything. It has been refined for superluxurious city use. The jeep is as outdoors as a hunting dog."

\section{The Plastic Car}

Several materials may be expected to compete for the honor of forming the body of your postwar car. Plastics made of soy beans, resins, grains, petroleum, and other unlikely sounding products have a lot to recommend them. Robert A. Boyer, until recently a research engineer for Henry Ford, has built an all-plastic car body which is eight hundred pounds lighter than the standard model and has ten times the impact strength of steel. Boyer agrees that a plastic car may not be a 
great deal better than a steel car, "but plastics will enable us to build a better car at lower cost."

Plastic bodies will be built in panels. In case of a wreck, only the damaged panel would have to be replaced. In the future, dealers may stock body panels as well as parts. You can stop worrying about the usual crop of scratches and dents that a car generally picks up in the course of a year's driving. Plastic bodies can take punishment. A husky man smacked the Ford plastic car with an ax and failed to dent it. For another thing, the smooth, hard finish on your plastic car is built in to stay forever.

Molded plywood-alternate layers of wood and plastic baked into shape under pressure-will give plastics a lot of competition. Factories now are turning out molded-plywood tails, wings, and fuselages for training planes, and fuselages for bombers and cargo planes. The fuselage of Britain's De Haviland twin-engined Mosquito bomber, which carries two thousand pounds of bombs and has a range of three thousand miles, is made of two layers of plywood with a center of balsa sandwiched between them. It takes hours to plug bulletholes in a metal plane, but a wooden Mosquito bomber can be patched in a few minutes.

Plastics and plastic plywood both will be challenged by aluminum and magnesium alloys. These two metals are vital in airplane construction. Wartime necessity has tremendously expanded our output of aluminum and magnesium, and lowered their price so they will be available for low-cost cars. In 1941, automobiles used an average of only seven pounds of aluminum, while magnesium was, until a few years ago, a structural curiosity. A lighter, but strong, automobile chassis will be made from aluminum and magnesium alloys. In addition, welding will replace bolts and rivets in the construction of the chassis.

Some automotive engineers are confident that steel will not 
be elbowed out of the race by other rivals. They explain that although stainless steel is three times as heavy as the lightmetal alloys it is so much stronger that only one-third as much need be used. They believe that further experiments with light-gauge steel will permit them to do as much with it as with the light metals.

\section{New Gasoline}

Tremendous improvement in gasoline not only will permit the use of lighter, smaller engines but will require the construction of entirely new engines to burn this fuel. The Socony-Vacuum Oil Company reports that its new gasoline is so powerful that no engine now in operation can make full use of it.

The big oil companies are producing immense quantities of powerful (high-octane) gasoline for military use. This fuel should hasten the day of victory. It adds 15 per cent to the operating range of our bombers and permits an increased load of two to three tons of bombs for every ten tons they carry today. It enables fighter planes to get "upstairs" faster-a priceless asset in aerial combat. Cargo planes carry heavier loads to far-flung battle fronts because their engines have the extra power needed for the job.

This extra power is made possible because high-octane gasoline gets rid of the "knock" in engines. When fuel "knocks" in an engine it is not burning evenly and efficiently. In order to build a high-compression engine it was necessary to develop high-octane "antiknock" gasoline.

Several years ago chemists worked out an "octane scale" to measure the efficiency and "antiknock" quality of gasoline. The "roo octane". rating was given a variety of fuel that would be 100 per cent antiknock. Then the chemists began shooting at the roo octane goal. 
First Dr. Thomas Midgley, Jr., discovered that a few drops of tetraethyl lead (composed of lead and alcohol) in gasoline made it burn evenly and halted the knocking. But, since tetraethyl lead's effectiveness strangely decreases as the amount added to gasoline increases, it could not raise the octane rating of gasoline above 87 -the type of fuel our military planes used for years.

So, instead of adding anything more to gasoline, the chemists took the second step. They began to rebuild the fuel itself. Crude oil is a complicated compound of hydrogen and carbon, with smaller amounts of sulphur, oxygen, and a few other elements. By a refining process known as "cracking," the hydrocarbon molecules are cracked apart under terrific pressure and heat. Then they are hooked together again to form a new fuel-high-octane gasoline. Improvements in the cracking process have brought a great saving in petroleum supplies, because it can make high-octane fuel from heavy oils that otherwise could not be used for gasoline.

Today we have several fuels that exceed the roo octane rating. One superfuel - "triptane"-is reported to be 50 per cent more powerful than aviation gasoline. Only very small amounts of triptane can be made now, but it, and other superfuels, should be in quantity production in a few years.

Our capacity to produce powerful fuels will be available for civilian cars when the war is over. And the price will be low. These high-octane fuels will mean that if you now get eighteen miles per gallon you should get thirty or more in the postwar years.

\section{Future Traffic Solutions}

By now you may be saying, "This low-cost postwar dream car sounds fine. But it will merely be a nightmare to me unless something is done about traffic congestion and parking diffi- 
culties; blind crossings and reckless drivers, whose tribe seems to increase."

Highway and traffic engineers, and radio experts, are going to do sometbing about these problems. More superhighways, with underpasses and overpasses, will be built between large cities. (These highways also will be widened at certain points with landing strips for airplanes.) Crooked, narrow "bottleneck" streets in cities and towns will be straightened and widened, and elevated highways will be built to speed up city traffic. These jobs will cost a lot of money, but they will be worth it. It is estimated that traffic snarls cost several million dollars a year in New York City alone. The use of building roofs and basements for parking, an idea that has already been tried out in some cities, will be generally adopted in the future. No longer will street parking be permitted to cut the efficiency of expensive streets by 50 per cent.

\section{The Radio Traffic Cop}

In a few years your car radio may have two receiversone for your favorite dance band or news commentator and the other for the radio traffic cop, who will patrol the roads or be stationed at strategic spots. He will give you directions via standard national highway frequency, warning you of an accident down the road, a dangerous curve, a damaged bridge, or a blind crossing. And in a few more years the traffic cop may be hovering overhead in a helicopter to shepherd you around traffic jams or road hazards.

William S. Halstead, a New York City communications engineer, believes that the automobile of the future will emphasize safety in order to compete with low-cost airplanes. "Auto makers," he said, "have made the car safe. The postwar emphasis will be on making the driver safe. The most likely method to be used will be highway radio broadcasts 


\section{Cars of the 1960's}

which will feed caution and common sense into the ears of the driver and relieve his already strained eyes. The road marker of the future will be the radio."

\section{Radar for Driving Safety}

Radar, the war device that has been guarding our coasts and shipping lanes, will give aid and comfort to the motorist in years to come. Radar means RAdio Detecting And Ranging. It can spot the enemy beyond the range of human eyes and ears, and fog, clouds, storms, or darkness have no effect on its amazing powers. This electronic device sends out ultrahigh-frequency, radio waves. If these waves strike an enemy submarine, plane, or ship, they bounce back, and in doing so they locate and measure the distance to the enemy targets.

With Radar in your car you won't have to worry about a pea-soup fog or a blinding storm. The radio waves from your car will pierce the gloom and warn you if there is danger ahead.

Radio advances in the future may permit you to follow a direction beam just as planes do. No more poring over road maps. You tune in on the wave length of the city you wish to visit, and ride in on the beam.

\section{Postwar Dilemma}

At present the V Day plans of automobile makers call for a quick change-over to the production of slightly modified 1942 models. They explain that this procedure will help cushion anticipated widespread unemployment during the reconversion of industries to peacetime production, and also meet the heavy demand of eager buyers for new cars.

Leo H. Rich, an associate of Walter Dorwin Teague, an industrial designer, is critical of manufacturers who plan to 
return to 1942 models. He declared that manufacturers have educated the public to expect new models each year and that consumers, who are aware of the great strides industry is making during the war, are looking for remarkable improvements in postwar products.

"This does not mean," he said, "that the public expects or would welcome all the radical fantasies which have been dreamed of on various drawing boards, but it certainly doesn't expect that the war will have brought no progress."

Rich agreed that some manufacturers will have no chance to retool before peace, and some must resume production of 1942 models in order to bridge the gap and avoid unemployment. But he added that "this should be a stop-gap policy and manufacturers should disown any desire to capitalize on a sellers' market."

He suggested that $\mathrm{r} 94^{2}$ models be labeled "temporary" or "victory" models and that new designs should not have to wait until the market for these is exhausted.

Other commentators argue that when peace comes there will be few if any automobile tools or dies on hand to produce 1942 models. They say that now is the time for the industry to redesign an entirely new car. It is agreed that industry should swing into action quickly to prevent mass unemployment after the war. But the point then is made that consumers may sit tight and refuse to buy a 1942 model car, after having heard of the "big things" to come. Critics of the stopgap production plan also warn that if the automobile companies don't step out with new models other competitors may beat them to it and cut into their market.

Competition between airplane and automobile companies will speed the development of a new and better automobile. Teamwork on war production has put plane and auto companies in one another's "back yards." They may stay there when the war is over. Airplane engineers may want to 


\section{Cars of the 1960's}

use their "know how" with plastic panels, light metals, and compact, powerful engines to produce a light, low-cost car. Automotive engineers may welcome the chance to show how low-cost "family-style" planes can be mass-produced for a postwar civilian market. Both sides also have picked up ideas, new materials, and methods which they can use in their own industries. 


\section{V \\ YOUR FLYING FLIVVER}

IN LESs than a decade you may be using a small flivver plane, a helicopter, or an autogiro as often and as nonchalantly as you have been accustomed in the past to using the "family bus" for week-end trips and vacation outings. In fact, you may turn to flying in order to obtain relief from the strain of driving a car over congested highways.

The mass-production techniques that have been developed during wartime for the manufacture of a great variety of planes for war use mean low-cost planes for civilian use later on. Furthermore, the incessant testing, checking, and remodeling that have been going on during the war, making planes safer and still safer, mean flying ships for civilians later on that will be almost foolproof.

Scores of manufacturers already have their designs for civilian planes on paper. Most of them, such as the Cessna, Aeronca, Piper $C u b$, and Taylorcraft, will look something like the light planes of today. Several of these planes will, however, have four-wheel landing gear and folding wings so they can be operated both as a plane and as a car. All of them will have improved engines for low-cost operation and will take off and land safely in small areas.

The light plane has been tested in battle and found strictly A-I in performance. "L"-type Grasshoppers (liaison planes which hedgehop from point to point during battles) are as versatile and hard to hurt as the Army's jeep. Able to take off and land on all sorts of terrain, and to duck among trees or fly slowly to avoid enemy "chicken hawks," the Grassboppers 
are ideal as observation craft. Equipped with two-way radio and manned by a pilot and observer, the Grasshoppers spot enemy guns and direct the fire of our artillery. These planes also can transport men and materials to front-line points which could not be reached by heavy cargo planes. They have served successfully as hospital planes for the evacuation of wounded. Other types of light, unarmored planes are used as training craft for pilots.

\section{Your First Plane-the Helicopter}

Unless you are air-minded and have already had some experience in piloting a plane, your first flying ship may well be a helicopter. You will regard this rotary-wing craft with affection and esteem because of the ease and simplicity with which it can be operated. Its horizontal, revolving blades enable it to fly straight up, straight down, forward, backward, sideways, and to hover stationary in the air like a gnat or hummingbird. It can operate from your back yard, the roof of an office building, or a side street. Most airplanes are still demanding creatures when it comes to take-off and landing space. The helicopter asks no favors. All it requires is space large enough to contain its structure.

Igor Ivan Sikorsky, the designer of one of the first successful helicopters, contends that it is far simpler to handle than a plane. "In the conventional craft," he explains, "you can't make the controls function effectively for flight under a forward speed of less than 50 or $60 \mathrm{mph}$. But in the helicopter, you can stay in one place and learn everything you need to know in complete safety.

"You can get in your new helicopter, speed up the rotor blades, and pull the left lift lever, but you don't rise, as you expect, to a disconcerting height; instead, a cable attached to the helicopter holds it some four feet above the ground, per- 
mitting you safely and easily to study the control movements. How simple this method of accustoming yourself to flying a helicopter! And I am certain that flying a direct-lift machine will become, in time, just as much an automatic habit as driving your motorcar is now."

\section{How to Fly a Helicopter}

The controls of the helicopter are easy to operate. A convertible model, which can be driven like a car, has a clutch for applying the engine's power to the wheels. Thus you don't have to push the helicopter out of the garage. You open the doors and drive it out. Or your garage may have a roll-back roof so that the helicopter can rise straight up and be on its way.

There is a tachometer on the instrument panel which counts the number of revolutions a minute made by the rotor blades. When you want to ascend you open the throttle and watch the tachometer until the rotor blades are making two hundred and forty revolutions a minute. Then you slowly pull the left-hand lever, which changes the pitch of the rotor blades so they bite more deeply into the air. The helicopter begins to rise, and its ascent can be controlled by changing the pitch of the rotor blades. After you reach the proper altitude you push a center control stick forward. This stick tilts the rotor blades slightly. They bite the air in a forward motion and the helicopter begins to move. Except for ascending and descending, all movements of the helicopter are controlled by the center stick.

When you reach your destination and want to descend you pull back the center stick. The craft comes to a stop and hovers over one spot. Then you release the lift lever, the rotor blades bite less powerfully at the air, and the helicopter sinks slowly to the earth. You can descend at the rate of one foot 
a minute if necessary, and maneuver to the right, left, or backward and forward, by manipulating the center stick. You can spend as much time as you need in landing, backing up, or shifting sideways to park in a tight spot.

What about weather conditions? Suppose you run into a fog? Well, you can descend at a snail's pace to check your location, and even use a flashlight to study road signs while the helicopter hovers near the ground. If an obstruction suddenly looms up in front of you, a pull on the center stick and an adjustment of the lift lever permit the helicopter to climb straight up or settle straight down and avoid a crash.

If your engine quits, a clutch automatically disengages the rotor blades. They continue to spin by the air pressure, like the rotor of an autogiro. The spinning blades enable the craft to descend safely from any altitude. It can glide in any direction to a desired landing space and then settle the short distance into it vertically. A heavy snowfall will ground planes and halt motor traffic, but the helicopter can rise directly from the snow and go anywhere. An amphibian helicopter, equipped with rubber pontoons, can land or take off easily from either water or land.

\section{Sikorsky's First Helicopter}

Mr. Sikorsky designed his first helicopter at Kiev, Russia, in 1908. An extraordinary child-genius, and the son of a professor of psychology at Kiev University, the young Russian's first designs were regarded with interest and curiosity by government officials. He was encouraged to go ahead with his work. But he had difficulty in obtaining the proper materials, and when he had finally assembled the odd-looking craft (contrived of a variety of unorthodox materials) it merely flopped around like a hen with her head off. He tried again 
and failed a second time. When the first world war commenced he turned to the designing of huge land planes. Officials of the War Department remembered the tall blueeyed young man from Kiev and, disregarding his tender years, ordered the construction of four hundred of his bombing planes. He was then eighteen years old.

Faith in Sikorsky's designs was engendered not merely by the performance of his model but by his personal history. He had possessed not only a phenomenal mechanical bent as a small child but a remarkable intellectual development. He graduated from college at an age when most youngsters are still in the preparatory grades. At eighteen he was a mature and experienced inventor. Faith in his machines proved justified, for of the four hundred bombers only two were lost during the war!

When the Revolution of r917 commenced, Sikorsky came to America and continued to build successful planes. But he had not given up his idea for a direct-lift machine. In 1939 his helicopter flew. By 1943 he had made eighteen major changes in the craft. The first helicopter carried three forty-six-inch radius propellers at the tail for control. All three propellers had variable-pitch blades controllable by the stick in the cockpit of the craft. In r 94 I the main rotor was changed so that the pitch of the individual blades could be varied as they passed each side of the ship. Additional work resulted in a refinement of the main rotor so that the pitch of the individual blades could be varied throughout its entire circuit. Each blade can, for example, be made to decrease pitch as it passes the front of the ship and to increase pitch as it passes over the tail. This tilts the rotor forward and causes the ship to move forward. The brilliant engineering work on the main rotor permitted Sikorsky to eliminate two of the propellers on the tail of his ship. Only one rotor in addition to the main one is needed, and it faces sideways at the tail to act as a rud- 
der. He is, however still working to make the helicopter more efficient. In May, 1943, United States patents were issued on two more designs by Mr. Sikorsky.

\section{War Duties of the Helicopter}

The helicopter already has taken over several jobs in this war, and may prove a decisive weapon against Axis submarines. In April, 1943, Captain Leland P. Lovette, Director of Public Relations of the Navy, announced that the five-hundred-mile "gap" in the mid-Atlantic where the German submarines have been particularly successful was being patrolled by ship-based helicopters. This craft can stop in the air motionless to scout for surfacing U-boats, zigzag around easily to avoid gunfire, and then drop depth charges on undersea raiders. Or it can fly at one hundred miles per hour in making a patrol from a ship.

In a demonstration on Long Island Sound, May 6-7, 1943, Colonel H. F. Gregory, of Wright Field, Ohio, made twentyfour landings and take-offs (some of them backward) from the deck of a tanker traveling at various speeds. The take-off space was seventy-eight by forty-eight feet. As a result of these tests, Rear Admiral Howard L. Vickery, vice-chairman of the Maritime Commission and Deputy War Shipping Administrator, said a small deck would be installed on Liberty ships which "will permit helicopters to be used at sea, thus giving the ships added protection from submarines."

\section{Postwar Tasks of the Helicopter}

The Army has ordered three hundred helicopters from the Sikorsky Division of the United Aircraft Corporation. Officers believe these rotary-wing craft can serve to spot targets for the artillery, lay telephone wire over impassable ground, hover 
near the ground while careful studies are made of topography, and rescue persons from crashes in inaccessible places. The helicopter's work for the Army during the war should speed the development of a model for civilian use when the war is over.

"The helicopter may be a vital factor in the period of demobilization of the aircraft industry after the war, permitting the utilization of facilities and the employment of a gradually increasing part of the trained personnel which will become available," declares Mr. Sikorsky. "Once they are in mass production, helicopters will cost about as much as medium-priced cars, and they are more adaptable to assembly line methods than the conventional plane."

Mr. Sikorsky visualizes a practical postwar helicopter, seating from twelve to twenty persons, as an "aerial taxi" which will meet the larger higher-speed air liners of today at various terminals and carry passengers to virtually any designated location. He declared the helicopter has limitless possibilities as an aerial "commuting" vehicle. If Mr. Sikorsky's ideas are developed, they will answer the complaint of one businessman who told of making a four-hour trip by air liner from Chicago to New York and then spending almost that much time battling New York City traffic from La Guardia Field to his home across the Hudson River in New Jersey. The helicopter's ability to operate in crowded areas, and still avoid traffic jams, should make it increasingly popular in large cities.

The Sikorsky helicopter is not designed for high-speed, long-range transportation of heavy loads. It may never carry more than twelve to twenty persons or their equivalent in freight. The top speed of the Sikorsky helicopter will probably be around one hundred and forty to one hundred and fifty miles per hour. It will, however, take over short hauls of light freight and express.

"There will be special delivery of perishable food to your 
home," declares Mr. Sikorsky. "By the use of a helicopter shuttle service, oranges that yesterday were on the trees in Florida and California will be moved today to the big airfreight terminals and dropped off. They will then reach your grocer the next day by the freight-helicopter connecting lines to small centers of the population-and from your grocer they will come to your door by his helicopter service."

It seems more than probable that helicopters will also expedite the settlement of vast areas of land in this country that are as yet sparsely populated, and incidentally increase the value of summer-resort property within a radius of three hundred miles of the large cities. That cabin in the mountains that you would visit more often if the trip did not mean such a long drive will become accessible within a couple of hours by helicopter.

"I am convinced," Mr. Sikorsky declared, "that within a decade after the war there will be hundreds of thousands, and possibly a million, helicopters in actual use in this country."

This prediction seems reasonable enough-considering that Mr. Sikorsky is making it about a machine of his own design. It is well known among designers that Sikorsky has a mania about making his planes safe to fly. This is nothing new. $\mathrm{He}$ was fuming and fretting about adding safety measures and devices to his huge land planes back in the early days of the first World War when most designers were still congratulating themselves that the flying machine would actually stay in the air for a reasonable period. Evidences of this fetish are to be found in every plane he ever designed, including the fighter planes.

\section{The De Botbezat Helicopter}

Stranger-looking and more revolutionary in design than Sikorsky's helicopter is the new-type helicopter designed and 
built by George de Bothezat, the Russian-born inventor who built the world's first successful man-carrying helicopter, in 1922, for the United States Army.

De Bothezat's all-metal ship, the GB-5, has twin rotors which turn in opposite directions. They are placed one above the other with the motor between them. The coaxial rotors overcome the tendency of the body of the plane to spin and no tail rotor is required for steering or counteracting torque.

The controls determine the plane's direction and attitude of flight in the same manner as do those of the Sikorskydesigned helicopter. The advantage of the De Bothezat craft lies in its greater lifting power, which, understandably, increases with the number of lifting surfaces. There appears to be no reason why the De Bothezat helicopter cannot be made to travel as fast as any conventional airplane of equal capacity. It is reasonable to suppose that multirotored ships, incorporating the De Bothezat design, can be built to carry three hundred passengers at a speed of three hundred and fifty miles per hour.

\section{The Helicab}

William B. Stout, director of research for Consolidated Vultee, has designed three distinct types of aircraft for postwar civilian use, among them his "Helicab" of helicopter design. This flying flivver will be about twenty-five feet long, six feet wide, and eight feet high. The rounded plastic nose of the teardrop-shaped fuselage will enable the passengerstwo to five-to see out on all sides. Its one hundred and twenty-five horsepower engine will be of conventional design but lighter in weight. Torque will be counteracted by the rotation of a vertically mounted propeller on the tail. As in any other helicopter, direction of flight will be controlled by adjusting the pitch of the main rotor. However, a simplified 
method of changing the blade angle is featured in Stout's craft.

\section{The Autogiro}

"What is the difference between the autogiro and the helicopter?" you may wonder.

The autogiro has a propeller in front like an ordinary plane, plus wings on top which revolve as the propeller pulls the plane through the air. These wings revolve solely as the result of the plane's motion through the air. The helicopter has no propeller in front. Its engine is attached directly to the blades on top, which enable it to ascend and descend vertically. The autogiro is easier to andle than the conventional plane. It takes off and lands in small places. But it is not as controllable as the helicopter.

The Pitcairn-Larsen Autogiro Company manufactures a craft that takes a smooth hop, skip, and jump in getting off the ground. If the motor fails, the revolving blades let the plane down gently. These blades can also be folded back to convert the autogiro into a passenger car.

\section{The Convertaplane}

Proponents of the Convertaplane say that everything we have written about the helicopter is doubly true of this halfhelicopter-half-plane invented and developed by Gerard P. Herrick, noted aeronautical engineer and instructor in the United States Army Air Corps during the first World War.

Like the helicopter, the Convertaplane will hover in midair, climb straight up, or settle slowly down; but it will also convert from a rotary-wing craft to a three hundred-mile-anhour airplane in mid-air. The Convertaplane looks like the conventional biplane, but there is a big difference. The slim 
upper wing can be released for rotation like the blades of the helicopter. This upper wing is specially designed so that when whirling it presents the same shape in cross section both coming and going. The newest Convertaplane design eliminates the bottom wing-thus making the ship a full-fledged helicopter when the rotor wing is turning, and an airplane with no trace of helicopter about it when the rotor wing is locked crosswise for high-speed flight. Future models of this ship also will be equipped so they can be converted into an automobile for short trips about town.

Mr. Herrick promises that the postwar Convertaplane will let you have your cake and eat it too. You might want a high-speed plane for cross-country trips, while your wife argues for a helicopter to use for shopping trips and visits to friends in the next county. Both can be satisfied by this halfhelicopter-half-plane.

\section{New Light Planes}

Like the many thousands of young fliers in the armed forces who will be returning to civilian life after the war, you may prefer a regular plane for pleasure flying-and your chief interest in a "flying flivver" is price.

William Stout believes the low-cost plane depends on the development of a hundred-dollar, hundred-horsepower, hundred-pound aviation engine with cylinders arranged in the "flat-opposed" style for greater streamlining. Stout proposes a two-speed propeller to help the engine get the plane into the air quickly. Combat planes use adjustable-pitch hydromatic or electric propellers, which are about as complicated as an ordinary auto engine and hence too expensive for the low-cost, light plane.

W. T. Piper, of the Piper Aircraft Company, favors lowerpowered engines of fifty to ninety horsepower, which will 
permit the construction of low-cost airplanes priced at a dollar a pound-2,000 pound plane, $\$ 2,000 ; 1,000$ pound plane, $\$ 1,000$. He argues that you will get plenty of speed, as well as low operating cost, with a low-powered engine, if the plane itself is properly streamlined to reduce costly drag. $\mathrm{He}$ estimates that a retractable landing gear, which draws the wheels inside the wings, will increase the plane's speed by twenty to thirty miles per hour. In the past only a few makers of light planes have installed retractable landing gears because of their expense. But mass-production methods will greatly reduce the cost per plane.

\section{Stout's Sky Cars}

In addition to the "Helicab," William Stout has drawn up plans for two new light planes-the "Roadable Airplane" and the "Aerocar," mass production of which is anticipated after the war.

The Roadable Airplane is intended for distance flights coupled with short trips on the ground. It will weigh no more than eight hundred pounds, have a thirty-foot wingspread, and be capable of taking four-hundred-mile cross-country hops. Since the Roadable Airplane is primarily an airplane and not a car, its best performance will be attained in flight. There it will reach speeds of one hundred and twenty miles per hour, while on the ground its speed will perhaps be limited to thirtyfive miles per hour.

The unique feature of the Roadable Airplane is that the wings can be folded back on landing. In case the pilot should run into bad weather, he can simply convert his plane into an automobile and hug the ground until the skies are clear.

The Aerocar is designed as the flying family automobile for tours and trips. Different from the Roadable Airplane, it is not primarily an airplane but a car that flies. It will weigh 
about fifteen hundred pounds, have a standard sixty-inch wheel tread, and do sixty to seventy miles per hour on the highway. The body will be transparent to give the passengers - it will carry three-a complete view on all sides.

When a person wishes to take to the air, he backs the Aerocar into the garage and attaches its combined wing and outrigger tail assembly. A pusher propeller is mounted at the rear. Once in the air, the plane will reach a speed of one hundred miles per hour, consuming the same amount of fuel as it would at sixty miles per hour on the ground. It will be able to cruise for a distance of two hundred and fifty miles. This will undoubtedly be the first airplane to be equipped with four wheels.

Neither the Roadable Airplane nor the Aerocar will be as practicable in congested city areas as the Helicab, but each will find its use.

\section{Simplified Flying Techniques}

All designers agree on the importance of designing a "foolproof" plane that will behave itself under all sorts of conditions. Of course, if a person is a poor automobile driver he will be unhappy in a plane. But if he can handle his car skillfully he will be able to fly well. W. T. Piper promises that the light plane will be practically foolproof "but not darnfoolproof."

A plane's control system directs the course of the ship by changing the position of parts of the wings or the tail so the air strikes them at a different angle. This permits the plane to change direction about any of its three axes-vertical, longitudinal, lateral.

The sideways motion of the plane about its vertical axis is controlled by the rudder on the tail. Pressure on the foot pedals moves the rudder, causes the air to blow the tail to one 
side or the other, and makes the nose of the plane swing toward the side on which pressure is applied.

The banking, or rolling, motion of the plane about its longitudinal axis is controlled by the ailerons on the wings. A sideward movement of the stick operates the ailerons, causes the air to push one wing down and the other up; and the plane banks in the direction that the stick was moved.

The up-and-down motion of the plane, or motion about its lateral axis, is controlled by the elevators on the tail. A forward movement of the stick moves the elevators down. The air pushes the tail up and the nose goes down. A backward movement of the stick moves the elevators up. The air pushes the tail down, and the nose rises.

Coordinated movements of the rudder, elevators, and ailerons can put the plane in any desired attitude. Learning to fly is merely the development of skill in smoothly blending the control pressures on stick and rudder pedals to direct the course of the plane. This is easy to say and hard for some pilots to do. If they are heavy-handed, or timid, in handling the stick the plane will do all sorts of disconcerting things. The plane is like a trained horse in that it wants to feel that the person in charge really knows his business.

Each time the pilot uses one control he must carefully adjust some other control or the plane misbehaves. Use of the stick to bank the plane to the right or left will cause the nose of the plane to slew annoyingly in the opposite direction unless proper adjustments are made with the pedals controlling the rudder on the tail. For a left turn, for example, a slight pressure is applied to left rudder to start the nose swinging and, at the same time, the stick is pressed to the left to bank the plane. When the desired degree of bank has been reached, rudder pressure is relaxed and the stick returned to neutral position. The plane will continue the turn. Recovery is effected by pressing right rudder and bringing the stick 
to the right. Controls are again returned to neutral as the ship resumes its level flight attitude.

If you own one of the new light planes of tomorrow you won't have to worry much about the above information. These planes-including the Ercoupe, produced by Engineering and Research Corporation, and the Skyfarer, built by the General Aircraft Corporation-provide a wheel control which makes the ailerons and the rudder function together in a coordinated manner. The problem of banking the plane is solved by a simple twist of the wheel. This means that you will be able to learn to fly with greater ease and with little wear and tear on the nerves.

The first rule of the air is to maintain flying speed. The plane's wings provide lift, and if the plane slows down too much the wings don't catch the air at the proper angle. This causes the plane to stall (fall rapidly from lack of flying speed). Many accidents are caused by a too-slow landing approach-if a plane stalls at an altitude of fifty feet the pilot's chances of avoiding a crash are about zero. This danger is largely avoided by the new light planes. They will be equipped with wing flaps, which increase the lift of the wing and also act as air brakes to slow the landing speed. Tricycle and four-wheel landing gears will further reduce the chances for accidents. They will provide better visibility for take-offs and landings, keep the plane rolling straight on the ground, and eliminate the danger of somersaults.

\section{Safety at Night}

One of the toughest problems faced by a pilot is that of knowing the right height at which to cut his engine for a landing. This is particularly difficult if he is coming in over a darkened field. An invention on which a United States patent was granted in 1943 should permit landings to be made 


\section{Your Flying Flivver}

with greater safety. This device uses two beam-projecting lamps under the fuselage to tell the pilot when he is in the correct position for a landing. A rear lamp points to the rear. They are adjusted so that the point at which the beams cross, merging to form a single spot of light on the ground, is the correct height for the pilot to set his plane down. A mirror at the side of the cabin enables the pilot to pick up the two spots and to follow them until finally they blend into one. If they separate again, it is a sign that either the ground level or the plane's altitude has changed. So the pilot knows that he had better try again for a new landing approach. 


\section{VI \\ GLOBAL TRANSPORTATION}

IN TOMORRow's "Age of Air" all distances between places will be measured in terms of hours instead of miles. No place on earth will be more than forty-eight hours from your local airport. You will be able to spend your vacations in foreign lands that heretofore you may have seen only on motionpicture screens-India, Egypt, Australia, Argentina, China. And the cost of such a vacation will be somewhat less than it now costs you to travel to the other side of the United States.

You may go off on this world jaunt in a super-Clipper that houses one hundred and twenty passengers in the plane's wing. Sixty people could be comfortably accommodated in the dining salon, on the observation deck, and the promenade, and in the cocktail lounge. The plane would have a range of five thousand miles at a cruising speed of three hundred miles per hour. The engines would be placed within the structure so that they could be serviced or repaired while the plane was in flight. The super-Clipper would carry a crew of sixteen.

Just before the war began, Pan American Airlines launched a program for the construction of fifty giant Clippers, each capable of carrying one hundred and fifty-three passengers. The line anticipated a New York-to-London flight in ten hours at a one-way fare of one hundred dollars for each passenger.

Glenn L. Martin, president of the Glenn L. Martin Co., has designed a 250,000 pound airplane with six or more engines for trans-Atlantic service. It would carry a pay load of fifty thousand pounds-the equivalent of one hundred pas- 
sengers with eighty pounds of baggage apiece, plus twentyfive thousand pounds of mail, cargo, and express. He estimates that the plane would make the trip from New York to London in thirteen hours with the wind, and in nineteen hours against the wind.

The plane would have almost all the comforts of a luxury liner-equipped with showers and baths, a lounge where games could be played, and observation rooms.

An idea of the tremendous size of the 250,000 pound plane is gained by a study of another Martin plane, the 140,000 pound Mars Flying Boat, which was built for the United States Navy. The Mars was originally designed as a patrol bomber, but has been converted for cargo use. It has four Wright Cyclone engines, and its fuel capacity is about a tankcar load.

The flight deck of the Mars is larger than the interior of a twenty-one-passenger airliner. Auxiliary motors drive eight generators supplying electricity, and there are twenty-four telephone stations on the plane for the crew of eleven men. Each of the Mars' twin rudders is twice as tall as a tall man, and between them are thirty-foot elevators. Each aileron is longer than the entire wing span of an average fighter plane.

The farsighted designer of the Mars is confident that domestic air travel will boom when the war is over. "But the spectacular development will be in the ocean field-the field of flying ships that will grow larger and larger. With them we shall rehabilitate a weary world, draw it closer together, re-establish the broken threads of commerce, cross the last frontiers of isolation." He added, "There is no technical limit to the size of planes; the only limit is the amount of payload available. We should be able to build 500,000-pound airplanes in a few years."

W. W. Davies, research engineer of United Airlines, wants 
the aviation industry to strike out and design a new and much larger luxury air liner for domestic passenger service. He envisions a four-engined, sixty-three-and-one-half-ton passenger plane with a cruising speed of two hundred and sixty-six miles per hour and a range of twenty-five hundred miles. Its engines would probably produce three thousand horsepower each. By day this de luxe plane would seat one hundred passengers and at night would have sleeping accommodations for fifty-six. There would be a comfortable lounge for passengers.

This engineer also predicts the development of another four-engined forty-ton plane which would offer service comparable to that in "club" or better-class railway-coach travel and would make more stops than the de luxe plane. Finally Mr. Davies favors the construction of a twenty-one-ton, twinengined plane to serve as a "variable load carrier." It would carry either passengers or cargo or both, and operate on feeder lines running from small towns and cities to the main routes of the air lines. A bulkhead would divide the passenger and cargo space in this plane and could be adjusted according to the number of passengers or cargo to be carried.

Edward Warner, vice-chairman of the Civil Aeronautics Board, agrees that passengers are likely to prefer one hundredpassenger planes to those carrying only twenty-five. But he warns that the larger planes will reduce the flexibility of the air lines' service. He explains that four twenty-five-passenger planes can give one hundred passengers nonstop service to four different points, while one one hundred-passenger giant can give nonstop service to only one point.

Mr. Warner also contends that the length of nonstop flights and the speed of air liners must be carefully considered if air lines want to cut passenger fares to three cents a mile or less. A six hundred-mile flight can be made at an operating cost of twenty-two cents a ton-mile, whereas a two thousandmile flight costs thirty cents per ton-mile mainly because of 
the extra load of gasoline which must be carried. The most economical air speed at moderate altitudes, he adds, is likely to remain below one hundred and eighty miles per hour. A four-hour flight from Chicago to New York costs forty dollars, while a two-hour flight would cost sixty dollars. Mr. Warner wonders whether people will pay an extra twenty dollars to save two hours' flying time.

Manufacturers have different ideas about the size of future sky liners. One concrete piece of evidence is the huge four hundred-passenger craft of Consolidated Vultee. A mock up of this plane has been built, and the problems of constructing such a giant air liner are being solved by Consolidated engineers.

\section{New Shipping Centers}

The flat mercator-type map no longer tells the story of distances in the coming Age of Air. On this map the shortest route between Washington and Tokyo appears to lie close to San Francisco. Pilots know, however, that the shortest route is a "Great Circle" course which passes over the Great Lakes, across Canada, and skirts Siberia. And the shortest route from Washington to Moscow via the "Great Circle" course just misses Greenland. Because the world's most important nations lie in the Northern Hemisphere, these "Great Circle" routes pass near or across the North Pole. The icy Arctic regions will become the "crossroads of commerce" in the postwar Age of Air.

"When we use the globe and 'Great Circle' measurements," says Colonel Edward S. Evans, president of Evans Products Company, "we find the Arctic Ocean, not the Atlantic, is the sea to be flown over. The Arctic becomes a Mediterranean between the Eastern and Western hemispheres. Chicago, Detroit, Cleveland, Cincinnati, and other western cities are 
going to come into their own as great shipping centers and 1 can vision the day when America will have a great port in Alaska which will supersede in importance our present great shipping centers. It could be the New York of tomorrow."

\section{$\$ 10,000,000$ Seadromes}

C. Bedeil Monro, president of Pennsylvania Central Airlines, would not use long-range super-Clippers for transAtlantic service. He contends that high-speed passenger travel across the Atlantic would be made safer and less expensive by the building of a "seadrome" route between the United States and Great Britain. Penn Central has filed with the $C A B$ an application to fly the route, in which three steel floating islands would be spaced at eight hundred-mile intervals across the Atlantic. The three "man-made islands" would each cost ten million dollars.

Mr. Monro asserts that the short eight hundred-mile hop between the seadromes means vastly increased passenger and cargo-carrying capacity because less gasoline would have to be carried. Two- or four-engined planes carrying forty-two to seventy-two passengers could be used. Only the same amount of gasoline would be required that now is used in making jumps of equal length overland. Passenger rates per mile, therefore, would be about the same.

The seadrome was invented by Edward R. Armstrong, a construction engineer of Philadelphia. Each "island" would stand seventy feet above sea level, and floats one hundred and sixty feet beneath the water would keep the seadrome "as steady as the mainland itself," said Mr. Armstrong. Each seadrome, weighing sixty-four thousand tons, would have complete airport and refueling facilities and a hotel where a traveler could stay if he wanted to wait for a later plane.

The Sun Shipbuilding \& Drydock Company maintains that 
it will construct the seadromes just as soon as steel is available. Associated with the Sun Corporation are United States Steel Corporation, the Wirth Steel Company, the Belmont Iron Works, and John A. Roebling Company.

Penn Central wishes to fly the route, but Mr. Monro stressed the fact that all air lines-even private flyers-would be permitted to use the seadromes. "Our seadrome idea has been proved sound," he added, "and we hope to get permission to install them as soon as victory has been won. Immediate postwar employment for thousands in the steel mills and shipbuilding yards, in their construction and transportation to fixed points at sea, will result. When successfully installed and in operation the seadromes will give valuable aid to shipping by providing hour-by-hour weather reports and forecasts never before obtainable. Light planes for iceberg spotting also could operate from the seadromes. Plans no doubt will be developed for more and more of them-for the Caribbean, Pacific, South Atlantic and everywhere they can be put to good use and for use of all."

\section{Passenger Stratoliners}

In the not-too-distant future, passenger-carrying stratoliners that fly at forty thousand feet, far above storms and dangerous icing regions, will be used extensively for global service. A number of new inventions now make this type of service feasible. One is a device patented April, 1943, that prevents the formation of ice on the leading edges of wings and propellers. It mounts a pair of infrared radiators on the sides of the plane's nose. They are focused to throw their beams on the leading edges of the wings. This "sun-lamp" treatment keeps the wings warmed above the icing temperature at all times. (The most dangerous temperatures for the formation of ice on airplanes are those between 20 and 34 
degrees Fahrenheit.) Smaller radiators are recessed in the propeller hub to keep the blades free of ice.

Another invention long in use but now more highly developed is the supercharger.

If you have ever been on a high mountain you will remember that the "thinness" of the air forced you to breathe harder and deeper. The lungs are flexible enough to make it possible, within certain limits, to compensate for the thinness of the air and get enough oxygen by breathing in more air. This is nature's way of "supercharging" the human engine.

To understand the all-important supercharger we should first remember that we live at the bottom of a vast ocean of air. Since the pressure of the air upon the outside of our bodies is equalized by the internal pressures of the body, we often forget that air has weight and exercises pressure. Designers of internal-combustion engines are very much aware that the air exerts a pressure of fourteen and seven-tenths pounds per square inch at sea level.

Because the air at higher altitudes contains less oxygen per cubic foot, and there is less pressure available for pushing the air into the cylinders, the power of a gasoline engine declines in relation to altitude. At twenty thousand feet a cubic foot of air weighs only about half as much as a cubic foot at sea level. If the engine is to get the same air pressure at twenty thousand feet as at sea level, we must give it twice as much of the thinner air. This is what the supercharger does. When the engine "gets out of breath" at high altitudes the supercharger forces extra air into its cylinders.

The turbosupercharger was perfected by Dr. Sanford B. Moss of General Electric. Since one part of the device operates in an arctic sixty-below-zero while the other spins in a blistering 1,500 degrees of heat, the turbosupercharger is an engineering masterpiece. 
High-altitude planes are greatly aided by hydromatic or electrically controlled propellers, which automatically control the pitch of the blades to permit the engine to operate at its greatest efficiency. For take-off the blade pitch is low to let the engine attain full power. In high pitch the blades bite into the air at a greater angle, and thus maintain thrust in thinner air. The high-pitch blades also prevent overspeeding of the engine when the plane is in level flight.

The speed at which the tip of the propeller blade turns must be kept below the speed of sound-about seven hundred and fifty miles per hour-or there will be an enormous increase in drag. The air fails to behave in its usual manner. The pressure generated at the forward point cannot get out of the way and so must be carried along by the moving object. To make it possible for both the propeller and the engine to turn at their most suitable speeds, a set of reduction gears is built into the nose section of the engine. The gears slow down the propeller to fifty to seventy-five revolutions for each one hundred of the engine.

How can the pilot of a high-altitude plane be protected? We have noted that a person's lungs are flexible enough for him to compensate for the thinness of air at high altitudes by breathing in more air. This "supercharging" operation works satisfactorily within certain limits. A healthy pilot has no trouble getting enough air in his lungs at ten thousand feet. But at twelve thousand feet a mask is needed to supply oxygen or the flyer loses efficiency. Because of the reduced air pressure, the higher the pilot goes the more need there is for oxygen to keep him normal. Above twenty-five thousand feet the air is so thin that it is impossible to whistle. At thirty-three thousand feet the pilot must be breathing 100 per cent pure oxygen or he will die.

If the pilot continues to go higher, he does not get enough 
oxygen even though he is breathing pure oxygen. This happens because the pressure above thirty-three thousand feet is so low that the lungs cannot breathe in enough oxygen even from a pure supply. At thirty thousand feet the air pressure is only 30 per cent of what it is at sea level, and only 19 per cent of the pressure at forty thousand. At sixty thousand feet the boiling point is so low that blood boils.

At around 35,300 feet (the tropopause) the temperature becomes fixed at 67 degrees below zero. This upper region of the atmosphere is known as the stratosphere. It is a "weatherless" region, free from clouds and with no strong vertical air currents.

In 1936 Squadron Leader Swain of the R.A.F. conquered the stratosphere. He reached an altitude of 49,144 feet, wearing a pressure suit made of rubberized fabric with a rubber helmet. A pump kept the suit inflated with pure oxygen at the proper pressure. Flight Lieutenant Adam of the R.A.F. later flew to 53,937 feet using the same suit, and in 1938 an Italian aviator set a world record of 56,047 .

The pressure suit has the advantage of adding little weight to the plane; but the suit still does not supply adequate pressure with full efficiency, and the pilot is so bundled up that his movements are awkward.

In 1937 the United States Army developed the first successful pressure cabin and took attention away from the pressure suit. The pressure cabin is ideal for the crew. An aviator's movements are not hampered by a bundlesome pressure suit. The Boeing Stratoliner-a commercial adaptation of the Flying Fortress-was equipped with a pressurized cabin for transcontinental flights at twenty thousand feet and for Pan American's fast flights over the Andes in South America.

The pressurized cabin did, however, have a serious defect for military use. A few bullets could destroy the effect of the 
pressure cabin and knock out the crew. Work is being rushed to make pressure cabins bullet-sealing like the fuel tanks of combat planes.

During the Battle of Britain the late Sir Frederick Banting, codiscoverer of insulin, said, "Whichever power gets up to 40,00o feet first and can stay there longest with the heaviest guns will win the war." Early in 1943 there were indications that the Germans were ready to make a desperate bid for aerial supremacy with fighter planes equipped with pressurized cabins. In November, 1942, the British reported that a German reconnaissance plane was shot down by a Spitfire at fifty thousand feet. The installation of heavy pressurized cabins on light fighter planes is considered an outstanding achievement. Experts, however, believe that these cabins will be used more extensively on huge new bombers. There have been frequent reports that the Army is preparing to bring out a giant bomber that will be able to carry destruction to the enemy at altitudes far beyond the reach of antiaircraft defenses and fighter planes. In hinting of the new bomber General H. H. Arnold, Air Forces Commander, remarked that the B-24 Liberators and the B-I 7 Flying Fortresses were the "last of the small bombers"! 1

\section{Air Cargo}

Public confidence in the safety and efficiency of air transport will bring a vast expansion of air-cargo business in postwar years. All forms of transportation have found that while

${ }^{1}$ The New York Times reported from Washington on November 4, 1943, that the "final test" of the Army's new superbomber, the B-29, "is not now far distant," according to General H. H. Arnold. The B-29 was developed by Boeing, the originator of the B-17 Flying Fortress. General Arnold said the B-29 "will have a range substantially greater than the maximum effective range of today's longest-range heary bombers." 
passenger revenue was considered the main source of income at first freight revenue eventually exceeded it. In $194 \mathrm{I}$ about 5 per cent of the air lines' revenue came from air expressor around I per cent of the railway express shipped. Thus the air lines' express business can be greatly expanded and still not make too much of a cut in railroad business.

The case of the airplane as a cargo carrier is one of simple arithmetic according to Wolfgang Langewiesche. "An airplane can make 20 round trips while ground transport makes one," he explains. "One ton of cargo space in an airplane is therefore worth 20 in a train or a truck, even without counting the value of time saved for the load. Between Burma and Chungking, where road transport was difficult but where cost was not counted, a Douglas transport was considered equivalent to 137 trucks. Between New York and Chicago the same sort of arithmetic holds true; mass transport is possible by air because the airplane is a fast worker."

Charles Froesch, chief engineer of Eastern Airlines, adds that "a cargo airplane should be a vehicle to carry merchandise not only at the lowest possible cost, but at the highest possible speed, as speed is the commodity which is paid for in air transportation." Noting that first-class rail express costs ten to twelve cents per ton mile, Mr. Froesch said the total cost of airplane shipping after the war would be brought "well below 15 cents per ton mile."

Rapid peacetime progress in the cargo- and passenger-plane field will be possible because of the powerful engines and other equipment produced during World War II. The horsepower of one of the three standard engines now used in our Army fighting planes has been increased more than 30 per cent since 1939 without any increase in the size of the engine and with a sharp reduction in the weight per horsepower. These engines all will provide high take-off power to get planes in the air with heavy loads, low fuel consumption at 
cruising speed for economy of operation, and low weight per horsepower.

\section{The Army's Air Transport Command}

Foreshadowing the cargo-carrying wings of the future is the Army's Air Transport Command. It is bigger than all the prewar air lines of the world combined, as to both route-miles flown and loads carried.

The ATC establishes and maintains bases wherever necessary for the transportation by air of cargo, personnel, and mail both within the United States and abroad. In early 1943 ATC's planes were operating over more than ninety thousand miles of transport routes, which were being extended as fighting fronts required more supplies in a hurry.

All sorts of cargoes are carried by the ATC. In cases of emergency, light tanks and jeeps are transported across the oceans by air. About the bulkiest objects commonly carried are airplane engines. These and plane parts of all kinds are frequently handled by ATC planes. Speed is the keynote of ATC operations. One ATC plane flew from Australia to California in the record flying time of thirty-three hours and twenty-seven minutes. Medical supplies and blood plasma are flown to their destinations. A complete hospital was flown to Alaska in thirty-six hours, replacing one that had burned to the ground.

Planes which fly vital war supplies to the fighting fronts usually do not return empty-handed. They come back loaded with strategic materials for war industry. Planes have brought block mica from India; platinum from the Persian Gulf; beryl ore, quartz crystals, industrial diamonds, and mica from South Africa. Crude rubber has been flown from Brazil and balsa wood from Central America. A certain type of Fiji Island beetle was "drafted" and flown to Honduras to make war on 
a root weevil attacking hemp. Planes also bring back wounded men from combat zones. Several seriously wounded men were transported from India to Washington in five days, a distance of more than ten thousand miles.

\section{The Naval Air Transport Service}

The Naval Air Transport Service, like the ATC, borrowed much of its personnel and operating procedure from commercial air lines. The NATS is operating several hundred planes, including many flying boats, over fifty thousand route miles. The most marked difference between the Army and Navy transport services is in the Navy's use of flying boats for cargo and personnel transport-including the evacuation of wounded from battle areas.

Strange cargoes also are carried by NATS- tons of rubber seeds from Liberia for planting in South America, blood plasma to New Guinea in three or four days. One of the NATS's outstanding jobs is transporting repair parts to battledamaged submarines in distant waters, thus permitting them to get back in action in a few days instead of being idle for a month or more.

\section{Speedier Loading Techniques}

William A. Lippman, Jr., former manager of freight and express for Western Air Lines, feels that "for obvious reasons" the three or four cargo types now being produced for the military will form the equipment backlog for air-freight operators for a considerable period after the war.

He warns, however, that the operator "who, by virtue of a desire to be first in the field, finds himself with a fleet of $\mathrm{C}-46, \mathrm{C}-47$, or $\mathrm{C}-54$ planes will find difficulty in bringing his costs into line with the public demand for competitive air 
freight rates-unless he can cut his ground time losses to the barest minimum, for time is the essence of all things."

Mr. Lippman says that "when the chips are down" the operator who keeps his planes in the air for the greatest number of hours out of each twenty-four will be the man who rakes in the pot. He revealed that observations made at an airfield where the ground time of planes averaged one hour indicated that only twenty minutes was needed to move the cargo into and out of the plane. The remaining forty minutes was used by four experienced handlers in unlashing and lashing cargo to the walls and deck with ropes.

Consider what that forty minutes cost the operator. A Douglas C-47 plane hauling an average pay load of 6,00o pounds at 180 miles per hour has a value of 540 ton-miles per hour as a commercial carrier ( 3 tons $\times 180 \mathrm{mph}$ ). At present air-express rates, the earning power of the $\mathrm{C}-47$ is $\$ 432$ per hour; so each cargo would then cost $\$ 1$ oo just to be made secure-without reckoning the handlers' salaries.

The above figures on ton-miles and earnings per hour explain why airplane designers and air-transport officials are interested in designing new cargo planes that will cut the time lost in loading and unloading. Some of these experts favor a high-wing, twin-engined monoplane (the $\mathrm{C}-76$ Caravan is of this type) built around a cargo space of at least $25 \times 8 \times 8$ feet -a railroad boxcar is about $40 \times 9 \times 9$.

Charles H. Babb, well-known aircraft broker, who can tell at any moment where most of the world's nonmilitary planes are, who owns them, and what shape they are in, has designed a cargo plane that is almost a freight car with wings. Loading and unloading the Babb plane would be facilitated by having a removable nose with a ramp for the landing of heavy mining machinery, trucks, and other bulky freight.

Harlan D. Fowler, who invented the Fowler flap to give greater lift to a plane's wing, has designed a cargo plane made 
of five separate and detachable cargo containers. Each container would hold one thousand pounds of freight, and any or all of them could be lifted from the plane by hoists and new ones put in place for a trip to another city.

In mid-1943 work was proceeding on the much-publicized Kaiser-Hughes H-KI Flying Boat. This giant all-plywood ship of 400,000 pounds gross weight will have eight engines, a fuel capacity of 8,000 gallons, I20,000 pounds cargo capacity, and a cruising speed of 174 miles per hour.

In designing cargo planes of the future, aeronautical engineers will be guided by this rule: the larger the plane the greater the percentage of pay load for the same proportion of horsepower. The load capacity of small planes is only about 25 per cent, while the load capacity of giant planes may run to $4^{\circ}$ per cent.

\section{Glider "Freight Trains"}

The use of cargo gliders towed by "locomotive planes" is expected to double an airplane's transport capacity, sharply reduce freight and express rates, and cut the time needed to load and unload cargo.

Grover Loening, consulting engineer of the Grumman Aircraft Corporation and a recipient of a Distinguished Service Award for the design and completion of the Loening twoseater fighter plane, contends that the use of the glider and the glider train "is probably the most significant development of all the recent items that have led to more and more efficient load-carrying on aircraft.

"Gliders are the freight trains of the air," he adds. "They give a versatility in the picking up and delivery of cargoes and passengers. We can visualize a locomotive plane leaving $\mathrm{La}$ Guardia Field towing a train of six gliders in the very near future. By the use of the glider system of carrying loads, 
the cargo capacity of a DC- 3 , for example, would be doubled.

"By having the load thus divided it would be practical to unhitch the glider that must come down in Philadelphia as the train flies over that place-similarly unhitching the loaded gliders for Washington, for Richmond, for Charleston, for Jacksonville, as each city is passed-and finally the air locomotive itself lands in Miami. During that process it has not had to make any intermediate landings, so that it has not had to slow down."

The savings in the cost of landings and take-offs of a heavy, powerful plane would be considerable. Three gliders plus the air locomotive would carry something like 190,000 pounds of freight at a speed of about one hundred and twenty to one hundred and fifty miles per hour.

Since it has no motor and propellers, the glider can be shaped so its nose resistance is one-third that of an airplane. The glider can be built much lighter, but its weight-carrying capacity would be approximately twice that of the transport plane. The weight of fuel, engines, and the heavier bracing in the transport plane could be replaced by pay load in the glider. Gliders can easily be pulled off the ground by their locomotive plane. They are safely in the air before the tow plane has left the ground. Army tests have proved that gliders can be taken in tow by the locomotive plane even though the plane itself is already in the air. The tow plane swoops down, hooks the towing cable of the glider, and pulls it gently off the ground.

"A few basic figures will give a fairly good concept of the advantages of this modern means of transportation," states Colonel Edward S. Evans. "The average train of loaded box cars carries 2,000 tons of freight at 25 miles an hour. Seven glider trains could deliver the same freight in one-tenth the time or, to express it differently, seven glider trains could 
deliver ten times as much freight as a railroad train in the same length of time. And the cargo will remain in much better condition since it will not be subjected to the shocks of switching and shunting."

Glider enthusiasts venture to predict that glider trains may lower air-freight rates to as little as three cents a ton-mile, and predict wide postwar use of this craft for passenger- as well as freight-carrying purposes. But the entire aviation industry is not in agreement on the glider's future. Some experts say the glider will be less important over long ranges in cargo carrying on a large scale. Some companies have, however, filed an application with the $\mathrm{CAB}$ for cargo-carrying air service which will use glider towing by aircraft.

On July 4, 1943, the R.A.F. disclosed that the first "airtrain" flight across the Atlantic had been made. A fully loaded glider carrying vaccines for Russia, and radio, aircraft, and motor parts, was towed thirty-five hundred miles from Montreal to England in twenty-eight hours. The R.A.F. Transport Command provided the officers and crews for this historic flight, but the equipment was American-made.

The glider-"Voo-Doo"-with an eighty-four-foot wingspread was piloted by Squadron Leader R. G. Seys, holder of the Distinguished Flying Cross. The tow plane was a twinengined Douglas transport.

"One of the things that gave us the greatest satisfaction" about our glider crossing of the Atlantic," remarked Squadron Leader Seys, "is that the critics have been confounded. Few people had much faith in glider flying. These were so few, indeed, that bets of 5-to-I were being offered against a successful flight-bets which none of us took. To be candid, I was more than somewhat frightened at the prospect of the tremendous haul before us. This was soon banished by the thrill of getting away according to plan." 


\section{The Rocket Motor}

Reports from Britain say that the Nazis use rocket power to get JU-88's off the ground with a three thousand-pound overload. The rockets are carried under the fuselage belly and are dropped when the plane attains the required take-off speed. Besides the use of rocket power (jet propulsion) there are indications that the Nazis also use tow lines as well as catapults to hurl their heavy planes into the air.

Experiments with small jet motors, conducted by Dr. R. H. Goddard, the American Rocket Society, and others, appear to prove that these motors warrant consideration as auxiliary booster motors to function during take-off or at any other time that a burst of great power is needed.

The jet or rocket motor is internal combustion in its simplest form. It usually consists only of a combustion chamber and a nozzle. Liquid fuels, usually hydrocarbons and liquid oxygen, are fed into the chamber under pressure. Upon ignition, by spark plug or other means, the combustion is continuous and the exhaust leaves the nozzle at great velocity, thereby creating an equal reaction in the opposite directionlike the recoil of a gun when it is fired. The force of this reaction depends upon the velocity of jet. Jet velocities have reached sixty-five hundred feet in a second (over four thousand miles per hour), which would be the speed of the rocket in an absolute vacuum. The rocket engine is the most inefficient of all motors at low speeds, but this should not hamper its use now. Effectiveness is more important than efficiency in wartime.

A jet-propelled aircraft, designed by Signor Campini and built by the Caproni Airplane Company of Milan, Italy, flew one hundred and sixty-eight miles at an average speed of one hundred and thirty miles per hour in December, 1941. Air is taken in at the hollow nose of this propellerless plane and ac- 
celerated through a tunnel toward the rear by an enginedriven compressor or blower. Fuel is burned in the air stream just before ejection at the nozzle. Since the oxygen used by the plane must be obtained from the air in which the plane flies, it, like other planes, is limited by the atmospheric pressure at high altitudes.

A rocket-propelled craft of the future, which carries its own fuel and oxygen, would become more and more efficient as it gained speed. In a perfect vacuum the plane would, theoretically, be roo per cent efficient because the forward velocity of the plane would equal the velocity of the propulsion jet.

\section{Radio Aids}

Numerous other wartime devices will be on hand to aid postwar commercial aviation. David Sarnoff, president of Radio Corporation of America, predicts a great advance in the science of radio, in which radio instruments will emerge from the war "almost human in their capabilities."

He pointed out that "the radio direction finder, which heretofore had only an ear, now also has an eye. The safety of aviation will be greatly enhanced, for the aviator will be able to see the ground through clouds or darkness. By the scientific application of the radio echo, the radio 'eye' will avert collisions, while the radio altimeter will measure the altitude and warn of mountains ahead or structures below."

The radio altimeter (or absolute altimeter) is a great improvement over the instrument used in past years. This altimeter is operated by the change in air pressure, and it gives only the altitude above sea level. A pilot flying at five thousand feet might pass over a peak at an altitude of only fifty feet, but the altimeter would show the altitude as five thousand feet. 
The absolute altimeter sends out an ultrahigh-frequency signal vertically to the ground and picks the signal up as it is reflected into the air. In addition, part of the signal is transmitted directly from the sending to the receiving antenna. The difference in time between the reception of the direct and reflected signals serves to give the pilot his exact altitude above the ground at all times.

Mr. Sarnoff described Radar (Radio Detecting And Ranging) as a great offensive and defensive weapon in wartime which will, in peacetime, assure both air and surface craft safe passage in any weather. Radar, plus the rapid improvement in blind or radio beam flying, should ultimately make air traffic almost roo per cent foolproof.

\section{The Finest Airways System on Earth}

No other country in the world has an airways system to match that maintained by the Civil Aeronautics Administration (CAA). Early in 1943 the CAA was operating three hundred and eleven lighted intermediate (emergency-landing) fields, one hundred and forty-two flashing beacons, and 2,098 rotating beacons along the Federal Airways System within the United States.

For the benefit of all airmen (not just air lines pilots) the CAA maintains and operates four hundred and eight intermediate-frequency radio range and marker stations, one hundred and ninety-seven ultrahigh-frequency radio fan markers, and seventy-two ultrahigh-frequency radio range stations (which probably will be increased to one hundred and fortythree during 1943). Also in the airways system are four hundred and forty-six weather-reporting stations, joined by a 54,000 mile teletype circuit for quick reporting of meteorological conditions from coast to coast. Traffic from point to point along the airways is directed from twenty-three control sta- 
tions, located at major airports. The control centers use a 10,400 mile teletype circuit to check and clear movements of swiftly traveling aircraft along the airways. Finally, at seventy-four designated fields the CAA operates airport control towers. This number will be increased, at the request of the military, to one hundred and twenty or more in 1943.

Since 1941 the Alaskan Airways System has been expanded and improved until Alaska now has as fine a system of airways and airports as any section of the United States.

The Federal Airways System now operates six intercontinental superradio stations capable of communicating with aircraft at any point on the globe. These stations have placed the United States several years ahead of any other nation in the world in the development of intercontinental airways.

The immediate postwar problems of the airways, as seen by the CAA, will be the rebuilding of the entire domestic airways system by substituting ultrahigh-frequency for the old standard intermediate frequency. Ultrahigh frequency will eliminate static and provide airmen with aerial "highway markers" as easy to follow as those along our best highways.

The CAA reports that, exclusive of certain military airdromes, there will be about eight hundred and sixty-five major airports in the United States by the end of 1943. All of them will have paved runways of thirty-five hundred feet or more, capable of handling the largest craft. Less than one hundred such fields existed in 1940. In addition to these there are more than two thousand lesser fields. Within the past few years numerous new airports for the use of military transports and combat planes have been built with American and Allied funds throughout the country. After the war many of these fields will be available for civilian use.

In planning future airways and other facilities, the CAA figures that before 1950 the United States may well have five hundred thousand private, commercial, and military planes in 
active service. Wolfgang Langewiesche contends that "we shall need an extension of the airways to the grass routes. That may mean low-cost 'flyways' for bad weather, extending to every town, with a landing strip every ten miles and perhaps regular sign posts, bearing numbers, marking the route."

\section{Solutions for Postwar Unemployment}

In 1943, according to the OWI, the total production of the American aviation industry-cargo and combat planes together-will reach the total of $\$ 20,100,000,000$, a fourth of our war budget for the year and almost a seventh of the estimated national income. This is in contrast with the auto industry, which at its peak in 1941 reached only $\$ 3,700,000,000$. About 2,500,000 trained workers are now turning out planes and almost all airplane plants can be converted to the production of peacetime aircraft.

Will aircraft plants shut down when the war ends and turn loose thousands of employees to hunt for jobs in other industries? It would appear that commercial and private equipment requirements will keep most factories busy for a while, and the military planes on hand will require an annual replacement of about 25 per cent because of losses and the fact that planes will get out of date.

Glenn L. Martin does not believe that the postwar years should hold any fears for the airplane industry. He predicts that after readjustments are made the plane builders will be even busier than they are right now turning out planes "for an aviation business bigger than anything we ever dreamed." He believes that in five or six years the industry "will be using at least all of its wartime workers."

Mr. Martin based his prophecy on these factors: ( 1 ) need for at least five years' replacement in domestic aviation; (2) 
demand for new military planes, especially types useful for policing the Axis nations; (3) development of the cargo glider, along with special tractor planes to tow them; (4) growth of international and oceanic air lines requiring hundreds of giant flying boats; (5) transportation of all mail, plus a substantial portion of express business, by air instead of by surface carriers; (6) expansion of the private plane market by thousands of wartime pilots who have learned to fly and will want to continue flying, and by thousands of other people who will have become "air-conditioned" during the war.

Other observers foresee a lot of jobs for pilots and workers, selling and servicing private planes and teaching people how to fly. Many other workers will be needed to operate new airports and maintain the flying aids on our airways.

New businesses will be organized to provide "taxi" planes for business and sight-seeing; for crop dusting, aerial photography, and other purposes. These organizations will provide jobs for pilots, mechanics, and office workers.

\section{Other Postwar Issues}

Experience gained by United States pilots and ground crews in the world-wide operations of ATC and NATS will give this country a long lead over Britain and other United Nations in the race for air-transport business when the war ends. Britain will be at a further disadvantage because the United States has been building most of the transport planes, while the British have concentrated on the production of bombers and fighters.

Referring to this fact, Juan Trippe, president of Pan American Airways, said that British Overseas Airways and the national air lines of the other United Nations should each be permitted to obtain from the United States, on equitable terms, all the ocean-transport planes they will need to restore the balance of fair competition. 
"We all share the healthy American aspiration to be the winner of a race or a ball game or an international business competition," he said. "But fair is fair. If you want to win a baseball game you try to out-hit and out-score the other fellow, but you don't take away his bat."

In a questionnaire on postwar air commerce which the $C A B$ sent to eighteen air lines the private companies indicated firm opposition to government participation in the management or ownership of their companies in the development of foreign air commerce. The air lines contended that past performance has shown that private management and initiative "are capable of successfully upholding the role of the United States in post-war transport."

They agreed with the CAB that the government should immediately arrange a reciprocal exchange with other countries for the general right of "innocent passage" (nonmilitary), together with the right to land for refuelling and for other technical needs.

Merchant ships long have enjoyed the right of "innocent passage" through waterways controlled by a foreign nation. Airplanes never have had this right. For example, an American ship on a voyage from Seattle to Alaska could pass through Canadian territorial waters without asking anybody's permission. But an American air transport on the same route would have to get express permission from Canada to fly over the same waters. The only "free" air lies over the oceans, beyond the three-mile limit.

"The right of "innocent passage," the air lines explained, "is basic to the development of international air transportation and leaves open for later negotiation and agreement the question of the right to engage in commerce by air." 1

Some American aviation experts fear that the granting of reciprocal trading rights to foreign nations will expose our air lines to dangerous foreign competition. They point out

1 Italics ours. 
that foreign merchant marines, operating with low wage standards and supported by their governments, were able to cripple the United States Merchant Marine after the first World War. Oliver J. Lissitzyn in his book International Air Transport and National Policy ${ }^{1}$ argues, however, that there is not likely to be much difference between air-transport costs in this nation and foreign countries, and that American companies will have the modern planes and the "know how" to hold their own by offering a high-quality service at reasonable rates.

It appears, too, that if we want the right to carry passengers and freight to foreign nations we will have to let them operate planes to and from the United States, just as foreign ships are permitted to trade to and from our ports.

Other observers warn against letting postwar competition for air traffic get out of hand. Bitter competition among the United Nations could wreck the teamwork that will be needed to hold Axis nations in check and preserve world peace.

"Air power," declares Juan Trippe, "can further anarchy or peace. It can destroy or build. It can be a lethal weapon or a life-giving tool-sword or ploughshare, Frankenstein monster or Aladdin's lamp, Stuka or Clipper. It can enslave man or set him free. ...

"It is obvious, of course, that the great national air transport monopolies, will continue to compete with each other and with us. But it is vital to establish an equitable basis for such competition. Friendship will result from fair play.

"The war," he concluded, "has been a bitter laboratory for air transport and its benefits should be made available to all the people in the peace to come."

${ }^{1}$ Lissitzyn, Oliver J., International Air Transport and National Policy. New York, Council of Foreign Relations, 1942. 


\section{VII}

\section{$B Y$ LANDANDSEA}

IT WOULD BE extremely unwise to compose an epitaph for the railroads, steamships, trucks, and busses at this point. Airplanes will compete strongly with surface transportation in the next few years, but these carriers are preparing to put up a stiff fight for business.

Furthermore, as W. A. Patterson, president of the United Airlines, pointed out, "If the volume of air-borne cargo increased one hundred fold it would still take only one tenth of one percent of the freight now being transported by the American railroads!

"The airplane and railroads," he added, "will be definitely competitive for certain types of express, but the gains which the railroads will achieve in freight traffic created by the airplane will more than offset their loss of passenger business to the airlines."

The railroads grew up with the United States, and their bands of steel helped bind the growing country together. In Europe the rails were laid between well-established cities. But in the United States the railroads pushed westward and people and towns followed. Because of the importance of transportation in the Far West, the states and the Federal Government stimulated railroad construction with loans and grants of land.

After 1920 the competition of oil pipe lines, automobiles, trucks, busses, inland waterways, and finally the airplane sharply cut railroad passenger and express business. Certain 
leaders in the railroad industry sought ways to meet this competition. In the early 1930's William Stout, the Detroit engineer, designed the first streamlined, lightweight, gasolinedriven train in the United States for the Pullman Car \& Manufacturing Corporation. The "Railplane" was made of welded steel tubing covered with duralumin, and Stout claimed that tests showed the Railplane truck was one-tenth the weight and two and a half times as strong as the standard railroad truck. Its two ${ }_{16} 6_{3}$ horsepower engines gave the Railplane a top speed of ninety miles per hour and it traveled on rubberlined wheel rims, which absorbed the shock. Sealed windows and forced ventilation assured passengers of a comfortable dust-free ride.

Several years passed, however, before the railroads began using streamlined and Diesel-motored trains to compete with airplanes, trucks, busses, and private automobiles. But by 1940 the United States had the largest number of trains in its history with scheduled runs of sixty miles per hour or more, and freight trains ran half again as fast and hauled more cars. Coaches were more comfortable and attractive than the Pullman cars used on all the first-class railroads a few years earlier.

Postwar advances in railroading will eclipse those made in prewar years. Abundant supplies of cheap aluminum and magnesium and new steel alloys, will permit the railroads to rebuild their rolling stock. The ever-busy Henry J. Kaiser announced in May, 1943, that he intends to turn out fast, lightweight railroad cars in the yards where he now produces ships.

"These yards," he explained, "can be quickly converted to handle railroad equipment. They can turn out welded cars on a mass production basis with speed and economy. We agree," he added, "that our railroads must be rebuilt after the 
war. We agree that thousands of shipyard workers must have jobs. This will do both."

Kaiser engineers have developed passenger coaches made of new steel alloys and aluminum and magnesium. They will be so light that one engine can pull two or three times the number on the same amount of fuel. Lightweight freight cars also have been planned. The substitution of light metals for steel in these cars will cut weight from forty-five thousand pounds to fifteen thousand. The cars can handle the nation's freight at twice the present speed and about half the cost, according to Mr. Kaiser. The drop in rail equipment and operating costs will permit the railroads to lower rates to compete favorably with other carriers.

The lightweight passenger coaches also will have improved air conditioning, cool fluorescent lighting, larger windows and sky-view roofs of strong transparent plastic, in addition to all the refinements of the best hotel.

Edward G. Budd, president of the manufacturing company bearing his name and a pioneer in the use of stainless steel for planes and trains, is confident that there should be a potential market for railway passenger cars "to the value of several hundred million dollars immediately upon the lifting of present restrictions."

Diesel motors-internal-combustion engines without spark plugs-will continue to grow in popularity on the railroads. Cost of operation is low for Diesels and they can outpull many steam locomotives. $M$. W. Smith, vice-president in charge of engineering for the Westinghouse Electric \& Manufacturing Co., believes, however, that efficient turbines will be used for trains as well as planes. He said that the highspeed gas turbine, using a continuous expansion of gas to rotate windmill-like blades and produce a steady flow of power, offers the possibility of another form of motive power 
for locomotives using either mechanical or electrical drives and transmissions.

He revealed early in 1943 that a steam-turbine-driven locomotive geared directly to the driving wheels actually has been designed and is about to be made and tested. Mr. Smith said it would supply higher power at faster speeds "exceeding that available from reciprocating steam locomotives." A 6,500 horsepower unit could, according to engineers, save more than 25 per cent in the pounds of steam per horsepower hour over the present-day locomotive. This points to more economical operation and, since it eliminates certain locomotive parts that move back and forth, it would cut wear and tear on moving parts, permit the use of smaller wheels, and allow more space for boilers.

A recent invention, on which a United States patent was granted in 1943, promises to greatly improve the present-day steam locomotive. It would give the railroad engine the advantage of more efficient, higher steam pressure now available to ships and power plants. The new design uses a horizontal water-tube boiler instead of the old-style fire-tube boiler. The tubes are suspended around a large fire space within the engine shell, and insulate it against the high firebox temperature-a method similar to that employed on ships. Steam is stored in eight or more vertical steam drums arranged in two rows down the sides of the locomotive.

\section{"The Battle of Transportation"}

When World War II began, Nazi experts were confident that the "obsolete" United States railroads would be unable to meet the demands of total war. They pointed out correctly that our railroads had less equipment than in 1916. But the railroads, with fewer locomotives, coaches, and freight cars, have broken every passenger- and freight-carrying record. 
Their performance under war handicaps indicates that they will be ready, willing, and able to give a good account of themselves against all competitors in postwar years.

Reporting on "the battle of transportation," the Office of War Information pointed out that the heavy blow delivered by Nazi submarines to intercoastal shipping through the Panama Canal, and to coastwise shipping along the Atlantic, had thrown a heavy burden on the railroads. Before the war emergency, said the OWI, one tanker used to leave the Gulf ports almost every hour with oil for the seventeen Eastern states and the District of Columbia, now known as District I. One million five hundred thousand barrels of oil a day were delivered to that region by water. Customarily only five or six thousand barrels a day were delivered by rail, virtually all of it special products such as asphalt, liquefied petroleum gases, and wax. Now East-coast tankers are few (the exact number of those in service is a war secret) and the railroads have taken over Eastern oil deliveries in a larger measure than was believed possible-even by themselves-when the emergency first arose.

"Somewhat less than in the case of oil, but still to a striking extent," the OWI reports, "the railroads have assumed the major burden of coal deliveries to the Northeast. New England, which in 1939 received three-quarters of its bituminous coal by collier, is now receiving over half by rail. . . . New York, which is more easily served by rail than is New England, now receives no collier deliveries from Hampton Roads."

In addition to the above shipments, the railroads are moving to ports quantities of Army and Lend-Lease exports which dwarf anything in the country's history. In $194^{2}$ they carried $638,000,000,000$ ton-miles of freight, an increase of a third over 194I, which had been the peak year, and OWI says the figure cannot help but rise in 1943 . 
The OWI compares the railroads' performance in the first World War and in World War II:

"During the last war, freight congestion on the railroads, particularly at and behind ports, became so great that war plants closed for lack of coal, fuel riots took place, goods spoiled on piers, and freight cars containing cargo needed for ships had to be lifted out of clogged yards by crane. This was due in large part to the facts that the railroad lacked any central agency among themselves (such as is now provided by the Car Service Division of the Association of American Railroads, which arranges for pooling of freight cars and other equipment), and that there was little cooperation between carrier and shipper, goods being routed to ports without any assurance that ship space would be ready. After the government took the railroads over in December, 1917, conditions improved. But at no time were there so few prolonged congestions as at present. And at no time during the last war did such an immense volume of freight move westward as well as eastward across the country as today.

"There is no talk, at the present time," the OWI adds, "of the government assuming ownership and operation of the railroads. ... The Army and Lend-Lease and other agencies agree that the control system is working 'reasonably well' and it is generally agreed that desire to avoid government controls has acted as a stimulus to the railroads to maintain a high degree of cooperation."

In its report on postwar transportation problems the National Resources Planning Board stated that "the future of the railroad lies in its continuance as the principal agency for heavy freight movement. The railways are capable, under a system of trainload operation and rates, of meeting much inland waterway competition, other than on the Great Lakes. Except for the waterways no agency of transport can seriously challenge them save on the shortest hauls." 


\section{Trucks and Busses Hold Their Own}

A survey by the Automotive Council of War Production of 227 truck operators showed that of 30,069 loads carried in a one-week period in 1943 almost 75 per cent conveyed military materials or products. Another survey, of $74 \mathrm{I}$ war plants, revealed that 65 per cent of incoming freight and 69 per cent of outgoing freight was being shipped by truck. Likewise the amount of shipping, both incoming and outgoing, carried by motor vehicles, averaged better than 50 per cent for I, 3 I I smaller firms in Minnesota, Missouri, and South Dakota.

Looking ahead to postwar years, the NRPB believes the fluidity and quick response in emergencies of truck transportation, which made it valuable in wartime, will enable it to hold business in the future.

"The motortruck is most useful," the NRPB reported, "in terminal service, on the shorter hauls, and over longer routes where its speed can equal or exceed that of rail operation. In the merchandise business, however, speed and flexibility of service, combined with favorable rates and minimum packing requirements make truck service especially attractive. Most less-than-carload business, except on the longest hauls, may eventually move by truck or by some form of coordinated service. In areas of light traffic density, along branch lines, and in local service along major channels of trade, the motortruck has another important place to fill."

Engineers of Mack Truck, Inc., foresee a great change in materials that form the body of postwar trucks. Magnesium, aluminum, and a host of other lightweight materials, such as plastic bonded plywood, will cut truck weight and allow for that much more weight in pay load. Major changes also are expected to take place in the engine. A lighter engine with greater horsepower in proportion to weight is being designed. High-octane gasoline, used now exclusively for aircraft, will 
play a major role in the development of more efficient engines. The NRPB also forecast the greater use of Diesels in trucks.

The "Truck of the Future," designed by Lurelle Guild, noted New York industrial designer, has a completely streamlined body enclosing the wheels. Front as well as rear loading, better load distribution, tandem front-driving axles, curved plastic windshield giving better vision in front, and periscope rear vision are among the other features provided by this vehicle.

Edward G. Budd pointed out that his company had just reached full-scale production of stainless-steel trailers at the outbreak of the war, and was assured of a large volume of this business in the postwar period because of the successful experience trucking companies had with the lighter type of trailer.

"Bus transportation," declared the NRPB, "has important advantages in short-distance traffic and in cross-country traffic between the major channels of movement. It also provides frequent and economical service in the light traffic areas which cannot be satisfactorily served by rail. Except on local hauls, however, good rail service can offer substantial competition."

Busses, as well as the railroads, will have to battle the air liners and passenger-carrying gliders. They are expected to match the railroads in providing fully air-conditioned coaches, with plastic windows, sky-view roofs, private compartments in front, and a lounge and observation room in the rear. A double-decked coach may be built like a huge trailer with the driver's cab and engine hitched on for ease in maneuvering.

Your travel dollar will buy a lot of comfort on these busses; and fares also will be low, because light-metal or plastic and plywood bodies, plus superefficient engines, will permit these 
vehicles to get twice as many miles per gallon of high-octane gasoline.

During the first World War the nation spent $\$ 3,000,000,000$ for a fleet of twenty-five hundred ships. But lack of a consistent government policy, plus competition from foreign ships supported by their governments and paying their crews lower wages, soon crippled the American Merchant Marine. In a dozen years the United States had only three hundred and forty-seven ocean ships. After Congress passed the Merchant Marine Act of 1936 real progress was made. New, modern ships were built in a program calling for fifty ships a year for ten years. Shipyards were put in good order so that when war came the shipbuilding industry was ready to expand operations rapidly. Officials say the Merchant Marine Act advanced the nation's wartime shipbuilding program by at least two years.

\section{Sbipbuilding Magic}

Prefabrication and welding have enabled American shipbuilders to break all records in turning out ships. No longer do they lay the keel and then build upward, riveting one plate at a time until the hull is finished. Today huge two-hundredton sections are fabricated near by and then lifted in place by cranes. Prefabrication has enabled Henry J. Kaiser's yards to cut shipbuilding time from months and weeks to days and hours.

Welding of plates not only saves time but economizes on man power, because one welder can join almost twice as many plates in a day as can a three-man riveting crew. Welding saves steel, because it does away with overlaps and the backup plates behind each seam where the large outer plates come together. Elimination of overlaps, as well as thousands of rivets, cuts down weight and permits ships to carry more 
cargo. This development, and greater use of steel alloys and light metals in postwar ships, will give shipping companies the faster ships needed to compete with foreign vessels and also with air transport.

Shipbuilders have set records in ship production, and shipping companies have exceeded past standards in seeing that every possible foot of cargo space in these vessels is utilized.

"In concrete benefit to the war," wrote William Bloeth, New York World-Telegram financial writer, "the industry has delivered more goods per ship and more goods over-all. The most worthwhile of these contributions has been the reduction of what is known as 'broken stowage,' a term for the waste space on a ship. The progress is freely called 'miraculous' both by experienced shipping men and by officials of the War Shipping Administration.

"Where, normally, a broken stowage of between 25 and 30 per cent was expected on a ship, careful attention to all details by experienced shipping men has trimmed this in war shipping to about 14 per cent on some routes. The figure is even more satisfactory in the light of the fact that absolutely no waste space is physically impossible," Bloeth adds.

"Spaces between deck beams, where no cargo could be stowed without lifting the deck and installing specially designed packages, still are computed in the theoretical capacity of a ship. Even with free-flowing grains, which can pour into all crevices, roo per cent is impossible. Even more significance is added by the fact that war cargo is 'balloon' cargo, taking up too much space for the weight involved. Military vehicles and tanks are the worst space-eaters and are important items in the cargoes being carried. The difficulty stems from the fact that a ship's capacity is limited by both weight and space. Bulky items don't add up to the peak weight, and heavy loads that hit the maximum weight before the holds are filled are considered bad stowage. These factors necessitate minute 
preparations and carefully worked-out plans, despite the need for wartime speed."

These wartime lessons in proper stowage of cargo will prove valuable to shipping companies in postwar years. They will have better ships, and also use them to greater advantage on world trade routes.

\section{The Diesels Step Abead}

In June, 1943, Captain Lisle F. Small told a meeting of the Society of Automotive Engineers that the United States Navy, under pressure of war, is undergoing a "revolutionary process of dieselization." He said that at the end of the first World War the Navy had Diesel engines only in submarines and the total horsepower of all of them was only 150,000. Now Diesels are "chunging" away to the total tune of I 2,000,000 horsepower on craft of all kinds, ranging from the mighty 45,000 ton lowa down to landing barges and the humblest tugboat.

"There has been a progressive slimming down of pounds per horsepower as new types of Diesels evolved," Captain Small declared. "In 1918 the engines of most of our submarines weighed 66.5 pounds per horsepower. The big Diesels in the German pocket battleship Spee, destroyed in the mouth of the Plate River early in the war, had got the weight down to 28 pounds per horsepower."

Improvements in Diesel design also speeded their use in cargo vessels. The Maritime Commission's fifty-ships-a-year program, begun in 1936, included a large number of Diesel motorships. The Donald McKay, first motorship completed, was rated one of the best cargo ships ever launched. Our greatly expanded wartime shipbuilding program called for the construction of Liberty and Victory ships using reciprocating steam engines, which were the easiest to build in the 
emergency. But the Maritime Commission also authorized the building of smaller numbers of ships in its long-range program-cargo ships of the $\mathrm{C}-\mathrm{I}, \mathrm{C}-2$, and $\mathrm{C}_{-3}$ types that use either Diesel or turbine power and can be used after the war. In addition, some of the slow-moving Liberty ships, which would not be considered economical in normal times, may be converted to Diesel motors in order to keep them in service.

The clearest outline of postwar shipping policy yet given by a government official was announced in a speech in June, 1943, by Admiral Emory S. Land, chairman of the Maritime Commission and War Shipping Administrator. He visualized a record-breaking peacetime merchant fleet of from fifteen million to twenty million tons, and also advocated the adoption of tramp shipping as a definite part of the maritime economy after the war.

Tramp shipping, which follows no definite routes or schedules but goes when and where cargo may be found, has heretofore been frowned upon by the commission as uneconomic. Admiral Land also favored private ownership, private operation, and private construction of ships; shipment of "a liberal percentage of our overseas traffic in American bottoms"; establishment of proper routes, lines, and services with a minimum of American competition necessary, and maintenance for the duration of the commission's policy of holding title to new ships.

"Post-war maritime objectives," Admiral Land declared, "are not being overlooked because of the exigencies of war. We are not losing sight of the objective manifestly set up in the Merchant Marine Act of 1936 which gives the Maritime Commission the duty of proper rehabilitation of the merchant marine.

"In order to plan properly for the after-the-war period," he added, "consideration must be given to the probable fleet under the American flag that will be in existence at the end 
of the war. We should definitely ear-mark for United States commerce a modern fleet of from $15,000,000$ to $20,000,000$ deadweight tons. As a nation of $135,000,000$ people, we are entitled to that tonnage. As the greatest shipbuilding nation in the world, we are entitled to have it as modern and up-todate as the exigencies of war permit."

\section{Airplane and Ship Competition}

C. I. Stanton, Civil Aeronautics Administrator, has some interesting facts and figures bearing on the coming battle between the airplane and the ship:

"It is perfectly obvious that in the not too distant future high-value cargo of all kinds will be commonly transported by air both domestically and overseas; planes will carry passengers, mail, express, and freight in ever-growing quantities. But why stretch the facts? Why claim that air transportation will be the only form of transportation? Far from bringing about a decrease in surface traffic, expanded air traffic will increase it, for the fuel to keep the planes in the air will have to be hauled by surface craft.

"A Clipper can carry $81 \frac{1}{2}$ tons of freight from New York to England if it refuels in Newfoundland, whereas a 10,000ton surface freighter can carry from six to eight thousand tons of cargo, together with fuel and stores for the round trip. Therefore a good many hundred Clipper trips would be needed to carry the tonnage which one 10,000-ton waterborne freighter can handle on one voyage. Furthermore, 8,500 tons of gasoline would have to be got to England to fuel these hundreds of Clipper trips back to Newfoundland, and 10,500 tons would have to be got to Newfoundland to fuel them between Newfoundland and England and Newfoundland and New York. Thus more than two surface freighter loads of gasoline must be carried to Newfoundland and Eng- 
land to permit the air delivery of a cargo which one freighter could carry across. This more than doubles the surface vessel cargo tonnage requirements. The more planes that fly, the more ships will have to sail."

Cargo ships do not appear to have much to fear from airtransport competition in the next few years. But ocean liners may be hard hit, and it is not likely that any new Queen Marys or Normandies will be built in the future. Nations whose national pride gives them a big-ship complex would do well to concentrate on luxury air liners for high-speed ocean trips and to build smaller passenger ships, which stress comfort, recreation, and safety. 


\section{VIII}

\section{YOUR NEW SERVANTS: THE ELECTRONIC "WATCHMEN"}

THE sCIENCE of electronics is the open-sesame to the doors of a miracle world. To date it has opened the door to the wonders of radio, sound moving pictures, and a great number of aids of which we are scarcely yet aware. In the world of tomorrow the electronic "watchmen" will protect your children from the prowling marauder and also from the deadly virus of infantile paralysis and other diseases that we have not yet conquered. A billion electronic "traffic policemen" will stand guard night and day to apprehend the speeding motorist and stop him at the next intersection, thereby reducing the hazards of driving. Thousands upon thousands of factory workers will be freed from the deadly monotony and fatigue of the assembly line while electronic "workmen" watch the presses, the conveyor belts, and the machinery; they will do all the checking, wrapping, sorting, packing, and counting in the future.

In the home there will be more than a dozen swift, silent electronic "maids" at the beck and call of the homemaker, freeing her from the drudgery of housekeeping. So far it has been possible to develop electronic robots for almost every imaginable task-and a good many that most of us would not imagine.

The war, which of necessity has stopped production and development in many fields, has given a tremendous acceleration to the development of all things electronic. Mass production of electronic equipment has increased by fantastic 
leaps and bounds. Mass production of other equipment has owed its tremendous growth to electronic devices. Radio frequency has cut the drying time of one type of plywood from three days to three minutes. Electronic eyes study a machine whirling at seven thousand revolutions per minute as though it were standing still, diagnosing the most minute flaw in its moving parts before that flaw becomes serious enough to cause a breakdown. Electronic research goes on apace. In November, 1942, the R.C.A. Radio-Electronic Laboratories were dedicated. Housed within a building almost five hundred feet long are one hundred and fifty laboratories where the secret weapons of today are being developed to win the war, and where new electronic wonders will become handmaidens of tomorrow's miracle world.

\section{Edison Discovered the Secret}

As far back as 1883 Thomas Edison discovered the secret which is the basis of electronics today. He was experimenting with his new invention, the electric-light bulb. He found that when he sealed a metal plate into the bulb, and connected that plate to the positive charge of a battery, current flowed from the heated filament of his light bulb to the positively charged plate. Current was flowing across empty space! Edison patented his discovery, and it has since been known as the "Edison effect." But the patent ran out before Edison attempted to develop it further.

Twenty-one years later, Professor J. A. Fleming developed this Edison effect into a vacuum tube which was called the "Fleming valve," and put this effect of current flow by "thermionic emission" to work. Edison had already stumbled on the fact that, if a substance is sealed in a vacuum tube and heated, electrons will be emitted from it, or evaporated, just as we can evaporate a pan of water by applying heat and boiling it rapidly. 
If we seal a piece of tungsten wire into a glass tube, and draw all the air out of the tube, and heat the wire, electrons will be emitted or evaporated from the wire. If we seal another piece of metal, called a plate or anode, into the tube, and connect the tube into an electric circuit so that there is a positive charge on the plate side of the circuit, the electrons which are emitted from the tungsten filament or cathode will jump through the space between the cathode and plate, and current will flow across empty space.

If the plus charge on the plate is increased, more and more electrons will be drawn to the plate and more and more current will flow. If the charge on the plate is changed to a negative charge, or an excess of electrons, the current will not flow.

Thus the diode, or two-element vacuum tube, gives us a one-way path for the flow of electric current. If we wish to change alternating current into direct, or one-way, current, we can put a diode in the circuit; and the current will flow but one way. We say the current has been rectified, and we call a tube used in this way a rectifier. The usefulness of the rectifier tube is limited only by the amount of voltage it can stand without breaking down. For a long time this was a severe limitation; the first rectifiers could not stand more than thirty volts! A three-element rectifier, called the thyratron, is capable of handling tremendous voltages.

What this one tube can mean to the power industry has been graphically stated by Raymond F. Yates in his article "The Coming Electric Age" in the Science Digest:

"The use of the new tube known as the thyratron will eventually save the industry many millions of dollars annually.

"For reasons well known to technicians, it has been impossible to transmit anything but high-voltage alternating current. We simply do not know how to generate high-voltage direct current, yet this would be the ideal current if we could 
step it up to voltages where it could be pushed through long transmission lines without serious losses.

"The thyratron, purely an electronic device, promises, for the first time in the history of the power industry, highvoltage direct current. A great and devastating revolution is threatened in the transmission of power. It will, however, be a constructive revolution and one of great benefit to both the manufacturer and the user of electric power.

"Because of line losses that do not occur when high-voltage direct current is used and because of the great difficulty of insulating high-voltage alternating-current lines, an alternating-current transmission line designed for 230,000 volts would carry no less than 300,000 volts of direct current. But that is not all the story; the actual power carried by the direct current would be from two to four times greater than the power carried by the alternating current.

"When it is estimated that $\$ 1,500,000,000$ has been invested in transmission lines, we begin to get some idea of the prodigious possibilities of this thyratron. If we are able to transmit only twice the amount of current over our existing lines, public utility assets will be created out of thin air."

That is but one example of the dramatic possibilities of vacuum tubes in industry. Even today they are used in more than one thousand unexpected ways. Tomorrow, who knows?

While the thyratron is used as a rectifier, in the manner of a diode, the thyratron is a triode, or three-element tube. This third element, the "grid," makes possible the instantaneous control of power by the tube.

James Stokley, of the General Electric Research Laboratories, gives this exceptionally good explanation of the action of the grid. ${ }^{1}$

"This was the invention of another American, Lee de Forest, in 1907. Between filament and plate he inserted a small

${ }^{1}$ Stokley, James, Science Remakes Our World. New York, Ives Washburn, 1942. 
screen, or grid, of wires. This can be thought of as a Venetian blind. Positively charged, the same as the filament, the blind is open and electrons pass through freely. But if it is gradually made negative, this is equivalent to closing the blind; and the stream of electrons is reduced and finally stopped. Such tubes made possible a new function-that of amplification. A very small current on the grid can control the flow of a larger current through the tube and, because of the instantaneous response, the quickest variations in the grid circuit are immediately reflected in the flow from the plate. . . .

"Another electron tube has found application in such varied tasks as controlling the lighting for a dance number on the stage of the Radio City Music Hall and welding the metal shell of a bombing plane. This is the thyratron. In one of its largest sizes, it will control 300,000 watts of power with less than half a watt applied to its grid!"

After the war the average man will reap the benefits not only of better electronic equipment of his own but of the effect of the speed-up on the production of many other articles by the introduction of electronic devices in factory production. Just as the machine age in manufacturing made the luxuries of yesterday the conveniences of today, so the electronic age in manufacturing will make the luxuries of today the conveniences of tomorrow.

\section{Radar}

When droves of German Stukas came over England in the historic Battle of Britain, Radar teamed up with R.A.F. Spitfires and Hurricanes to save the day. Radar warned the English pilots long before the German planes were overhead. It enabled "the few" to conserve, their strength, to get off the ground in time, to concentrate their forces where needed, and to fly at an altitude which would give them the needed advantages over enemy forces which vastly outnumbered them. 
The Radar "eye" in the nose of R.A.F. night fighter planes informed the pilot when a Nazi was within range and permitted the defending planes to hunt down the enemy even in the blackest night.

Radar gets much of the credit for saving Britain. It might have saved many ships and lives at Pearl Harbor. The United States Army Signal Corps Radar installation was not sleeping on the morning of December 7, 1941. Private Lockhard (now Lieutenant Lockhard, wearer of the D.S.M.) was getting in some extra practice on the Radar equipment when he spotted a large flight of planes more than half an hour's flying time from Pearl Harbor. He reported this information to his superior. But the officer knew (as the Japs probably also knew) that a large number of American planes were due, so he suspected nothing. The rest of the story is well known.

What is Radar? Radar uses a principle which is as familiar to us as an echo. Radio waves at very high frequencies, called U.H.F. for "ultrahigh frequencies," travel in a straight line and behave like a beam of light. They cannot be reflected back from the ionosphere, as can the longer waves of our everyday broadcast band. But they can be reflected back from a metal object. Therefore, if they hit a metal object, such as a ship, a plane, or a submarine, they will bounce back in a straight line toward the transmitter which shot them out into space. If there is a receiver located at the point of the transmitter, these radio waves can be picked up when they bounce back. And by timing the return in millionths of a second, the receiver equipment can tell just how long it took the radio waves to go out, strike this object, and bound back, and, consequently, just how far away the object is.

Radar is not so "new" a discovery as the layman might think. Twenty-one years ago Dr. A. Hoyt Taylor and Leo C. Young, now superintendent and assistant superintendent of the radio division of the Naval Research Laboratory, discovered that high-frequency waves would bounce back from 
metal objects, as an echo bounces from a wall or a mountainside. With the first detection devices it was possible only to determine that there was a metal object somewhere within range of the radio waves. Today a Radar unit, trained on an enemy field, can tell the Radar operator the instant planes take off from that field, how far away they are, how many there are, at what altitude they are flying, and at what speed. Thus it is possible for the Radar operators and their assistants to plot the course of the enemy planes and to determine to the split second when they will reach a given point, and the planes of the home defense can keep a very unexpected rendezvous with the enemy planes at a point of their choice.

The principle of Radar detection is likewise in use in directing gunfire. Hanson W. Baldwin, of the New York Times, reports a striking incident of the effectiveness of radio direction of gunfire in a naval battle:

"Radar enabled one of our modern battleships in a night action in the Solomons to locate, fire at and straddle on the first salvo a Japanese battleship eight miles away.

"The Japanese ship was never actually seen by our men until after she had been hit and was afire. Radar also played a role in various British naval victories in the Mediterranean.

"Radar is also of major importance in controlling the fire of antiaircraft guns, and at night has replaced, or supplemented searchlights."

It is the history of many scientific developments that their underlying principles are discovered, often simultaneously, in different countries of the world. Thus, while the American scientists were developing our version of Radar, in England a Scot, Robert Alexander (now Sir Robert) Watson-Watt, was developing Great Britain's version of Radar, which was to help win the Battle of Britain. It is known that Axis countries likewise have their version of Radar. Therefore the race in detection is a race to develop an instrument increasingly more effective, with a longer range and a more accurate deter- 
mination of the distance and direction of its target and the nature of the object it has spotted.

The lessening of the U-boat menace in recent months can very largely be attributed to the increased use of Radar detecting devices. Time was when the U-boat raider, lying on the surface on a pitch-black night, recharging batteries, was as safe as he'd be under the surface. Now the Radar operator can spot the surfaced U-boat, even though the night hides him or a blanket of fog covers him, and direct the bombing plane unerringly to the target. The U-boat never sees the plane approaching-may not even hear it. Without warning, bombs whistle through the black night and one more U-boat goes down for the last time.

Just as Radar, supersleuth, helped win the Battle of Britain, so it is helping now to win the battle over the U-boat menace. What of the peacetime uses of this wartime miracle? The editors of Newsweek summarize its possibilities thus:

"The development is significant for peace as well as war. It promises a peacetime future in which collisions at night between airplanes, or between airplanes and mountains, will be impossible. Pilots can also take off from and land on fog bound airdromes with perfect security. There will be no such necessity as 'blind flying.'

"Ships will be able to enter and leave harbors despite fogs that now make them helpless. And the perfection of 'beam communications' or the sending out of extremely narrow channels of electric signals, to be picked up by receivers aboard airplanes, will aid the navigation of every amateur pilot."

\section{Radio-Frequency Heating}

One of the most dramatic developments in manufacturing today is the widespread application of R.F., or radio- 
frequency, heating. Induction heating has been used for many years. R.F. heating is induction heating "stepped up" to radiofrequency speeds. Two methods of induction heating are used: electromagnetic heating is used for materials, such as metals, in which electric current flows easily; electrostatic heating is used for materials, such as wood and plastics, in which electric current does not flow easily.

In its simplest terms the process of electromagnetic heating may be explained thus. A current flowing through a wire sets up a magnetic field around the wire. If the wire is wound into a coil, the magnetic field will flow through the coil. Every time the direction of the current in the coil of wire changes, the direction of the magnetic field changes too. This changing magnetic field will set up or induce a voltage or electric pressure in a piece of metal which is inserted in the coil, and cause current to flow in the metal. The resistance of the metal to this flow of current causes the metal to heat. Thus the term "induction heating" or heating caused by an induced current.

With nonconductive materials, such as wood, "capacity" heating is used. The material to be heated is placed between two metal plates. As a constantly changing current causes a multitude of electrons to strike one of the plates, the electrons are driven from the other plate, or "repelled" from it, just as the two south poles of a magnet are repelled from each other. At the next instant, when a reversal of current drives electrons to the other plate, the electrons on the first plate are repelled from it. The material between the plates, as an innocent bystander, is caught in the thick of the argument. It feels the electric stress across it as the electrons on the two metal plates repel each other. The electrons within the material are not easily freed from their atoms; but they do feel the tug of this stress and they are displaced slightly, first to one side and then to the other. This displacement causes friction and 
induces heat in the wood or plastic, just as the current flow in the metal induces heat.

In any type of induction heating, the speed with which the current changes direction increases the speed with which the heat can be developed in the material being heated. We can comprehend the speed-up which results when induction heating is applied, not at the typical sixty cycles per second of our standard A.C. but at perhaps sixty million cycles per second of R.F. heating.

When Malaya and the Netherlands East Indies fell into Japanese hands, more than half the world's supply of tin fell into their hands too. When our precious supply of tin was so sharply curtailed, R.F. heating saved the day. R.F. heating tripled our supply of tin overnight, by making it possible to coat our tin cans with a coating one-third as thick as the coating formerly used. And resistance welding, which likewise uses heat at R.F. speeds of control, has eliminated the use of soldering in many places where it was heretofore used, freeing solder, which contains tin, for uses where it is still imperative.

When it became more and more desirable to use plastics and bonded plywoods in the construction of planes, both to save metal and to cut weight, R.F. heating again came to the rescue. The bottleneck in plywoods and plastics was the slow drying time. And R.F. heating has broken this bottleneck, giving us next year's production of propellers by tomorrow afternoon!

\section{$X$-Raying Steel}

The industrial use of $\mathrm{X}$ ray is speeding production as efficiently as the widespread use of R.F. heating. A threehundred-thousand-volt X-ray machine is used to "see" through four inches of steel, finding flaws in casts and weldings while 
they are merely flaws and have not become the cause of a tragic failure that could cost the lives of men. Recently a million-volt machine was used to "see" through eight-inch armor plate, and a new one-hundred-million-volt "induction electron accelerator" is being developed; so the future possibilities promise detection of flaws in even more massive castings. Airplanes are now being examined by $\mathrm{X}$-ray units which can see through five inches of steel, detecting any flaws. Tomorrow, when this equipment is generally available for commercial planes, it will save countless hours of checking time and many lives.

The X-ray diffraction camera is used to show not merely the flaws in a material but every element which goes into making that material. The slightest variation in a substance can be detected as quickly as we could distinguish chocolate from angel cake.

\section{The Pbotoelectric Tube}

One of the most interesting vacuum tubes in common use today is the photoelectric tube. In this tube the filament is coated with caesium or another metal which will emit electrons when light falls on the metal surface. When light shines on the tube, current flows; when something casts a shadow on the tube, the current stops instantly. By using various color filters with the tube, it can be made to respond to one color and not to another.

If the current from a photoelectric tube is fed to the grid of such a triode as the thyratron, it can start and stop large currents-thus starting and stopping heavy machinery. It is this tube which turns on a fountain as you bend to drink; your head interrupts the current flow, a switch is released, and the water is turned on. It is this tube which opens a heavy door as you approach. Your shadow interrupts the light beam 
on the tube, and the current flow; a switch is released, and a spring opens the door.

Phototubes are helping to speed the war effort in many places. In plants where trucks come in and out of doors several times a day, the phototube opens the door. How long does it take a truck driver to stop his truck at a door, climb down, open the door, climb back up in the truck, start his truck, roll through the open door, stop his truck again, climb down, close the door, climb up in his truck again, and roll on his way? Half a minute? Multiply that half minute by a hundred starts and stops for a thousand trucks, and the loss in man-minutes becomes a loss in man-hours. A doorman on the job could save the truckman's time. But today we cannot spare a man to "stand and wait." The phototube saves that time for us. As the truck approaches, the phototube opens the door, the truck rolls through without stopping, and the phototube closes the door behind it. It would be possible to use that same doorman as a guard, opening the door for trucks of a certain fleet and refusing admission to all others. All that would be necessary in equipping the phototube for this task would be a color filter to protect it from all light rays but those of a certain shade. Then, if the light source reaching the tube were reflected from the passing trucks, rather than interrupted by the passing trucks, only light reflected from trucks of a predetermined color would pass through the color filter and cause the current to flow in the phototube. In this case the flow of current rather than the stopping of current would activate the relays which operated the doors.

The ability of the phototube to distinguish shades of color has been brought to a high stage of perfection in the spectrophotometer, a device which uses the phototube. While the human eye can sometimes distinguish ten thousand different shades and colors, the spectrophotometer can distinguish two million different shades! 
Just as the phototube can distinguish shades of color with a skill surpassing that of the human eye, so other electronic watchmen can serve as inspectors of variations in weight and thickness, and all other physical properties, and perform each of these processes with superhuman skill and exactness.

Electronic watchmen can scan a sheet of metal running past at hundreds of feet a minute, detect a flaw no larger than a pinprick, and mark the metal for discard at that point-and all without stopping the flowing of production. When a sheet of metal is fed into a press, electronic watchmen can stand guard over the press, stopping the machinery if the sheet varies by a thickness far less than that of tissue paper.

Amateur photographers know the saving in film that results from the use of a light meter. This little meter, working on the principle of a photoelectric tube, measures illumination on a graduated scale and tells us how much light is reaching the meter in terms of how much current flows from the photocell. Thus we know how to set our cameras in order to get good pictures in varying degrees of light.

In the world of tomorrow this same principle will be used to measure illumination in our homes, schools, and factories. It will not be necessary for a human watchman to read the meter and adjust our lighting for efficiency, for the electronic watchman will take care of that, safeguarding our eyesight, by turning on artificial illumination the moment daylight fails. On winter days, when light is insufficient or fails quickly, our fallible human judgment will not subject us to an hour or more of eyestrain before we become aware that the light has dimmed.

The same phototube could be used to switch on the lights when one entered a room and-what price light bills?switch off the lights when we left a room. There would be a great future for the man who would perfect such a device for installation in hotel rooms! The device could count the 
people who entered, and not switch off the light until the last person had left the room. In fact, phototubes used to control traffic in one-way tunnels exercise just such ability to count even now.

Doubtless we can all remember a time in our childhood when we watched the pharmacist at the corner drugstore weighing the powders for a prescription. It was a long and tedious process. But, thought we, it takes time to get things exactly to a fraction of an ounce! Today electronic watchmen can weigh thousands of objects, instantly discarding any that are overweight or underweight by a thousandth part of an ounce-and do it all in seconds instead of minutes!

\section{Testing the Ripeness of a Melon}

Electronic inspectors adapt themselves exceptionally well to conditions where the ebb and flow of production is irregular. When a sudden spurt of production occurs, they can work tirelessly, day and night, with unfailing speed and accuracy. When production stops, they present no labor problems. Fruit growers have saved themselves thousands of dollars by using electronic inspectors for rapid sorting of fruit. Overweight, underweight, and off-color fruit is discarded with lightning speed as it whirls by at a speed which would overtax a corps of human inspectors.

Electronic testers can even check the ripeness of a melon, and tell you exactly when it reaches that state of luscious perfection that makes it worth the price! What a boon to the purchaser! And the electronic tester makes its test without bruising the fruit! What a boon to the merchant!

It is possible that someday an up-and-coming fruit market will install a "melon checker," just as the chain drugstore installs a tube checker for radio tubes. Surely it would pay for itself in a short time if flashing lights informed the prospec- 
tive purchaser-“Green" . . "Firm" . . "Just right!" . . . "Dead ripe-half price."

\section{Checking Moving Objects}

One of the most fascinating electronic instruments in use today is the stroboscope. Let us imagine we are watching the process as an engineer checks the revolutions per minute of a whirling machine. He will bring his stroboscope, which in appearance is simply a metal box with a strong flashlight in one end of it, a dial on top, and a meter he can read. $\mathrm{He}$ turns his "flashlight" on the machine and a strong glow of light illuminates a whirling wheel. It seems to us to be a steady light, but in reality it is flickering off and on so rapidly that we cannot detect the flicker. "Watch the wheel," he says, and we watch it. He turns his dial. A strange thing happens. He has not touched the machine; we can hear it still running at breakneck speed. But there, before our eyes, the wheel slows down, wavers, and stops! Seeing is no longer believing! Our ears tell us the wheel is still revolving. Our eyes tell us it is standing still. The engineer reads his meter. "Fifty-five hundred revolutions per minute," he says. He snaps off the light of the stroboscope, and again the wheel revolves before our eyes.

How is this possible? Because he has changed the frequency of the flickering of the light in his stroboscope until it is going off and on at exactly the speed at which the wheel was revolving; and, therefore, each time the light illuminated the wheel, it caught it in exactly the same position.

For a simple, quick, and accurate method of determining the speed of a revolving wheel, the stroboscope is invaluable. Likewise, it may be used to detect any "wobble". in the wheel which may develop at a given speed, so that this fault can be corrected before a breakdown occurs. It can also be used 
to illuminate any moving object while a camera takes a series of still-life pictures in all positions.

Just as the stroboscope makes it possible to check, study, and test a machine without stopping it, so other electronic devices make it possible to check other production without stopping the flow of material. The colorimeter makes it possible to check samples of a liquid without taking a sample and putting it through chemical analysis. As the liquid, in process of production or use, flows through a glass tube, the colorimeter analyzes it by color.

Welding has long made use of the advantages of electronic controls, for electronic timers truly can give the advantage of split-second timing. This accurate control has meant better welds, and safer welds, with unfailing accuracy. And X-ray examination of welding has furnished a further quick check to determine perfection. Resistance welding is speeding up the process of welding by making it possible not only to time the heat of a weld to the split second but to control the amount of heat applied to the weld, and to control it to a fraction of a degree.

\section{Nerw Medical Servants}

Electronics has long been the handmaiden of medicine. The electrocardiograph has made it possible to record the picture of the beating of a heart, giving the doctor a far more accurate diagnosis of certain heart conditions than is possible by any other means. It has enabled him to apply healing measures to correct a trouble before a sudden failure was the first warning that anything was wrong. The electric knife has made bloodless surgery possible. The use of $\mathrm{X}$ ray in diagnosis, in setting bones, and in treating certain diseases is widespread. A recent development, called the "laminograph" can X-ray a given layer of tissue, without recording a picture of other 
tissues. The electric probe is cutting from hours to mere minutes the time of searching for imbedded bits of metal in battle wounds, and saving many lives.

Perhaps the most outstanding recent electronic development, from the medical point of view, is the electron microscope. It is revealing to our scientists a world that was too minute for us to see, even with the aid of the finest optical microscope. The electron microscope will be the new handmaiden of medicine-penetrating the hitherto unknown secrets of diseases we have not yet conquered, such as infantile paralysis and influenza.

Some of the greatest developments which will safeguard health tomorrow will be preventive measures. Electronic controls will make possible germ-free air, to guard against disease; electronic devices will preserve food, guarding against contamination. Electronic irradiation of food will store more and more sunshine into what we eat.

There are countless other ways in which electronic devices save time, man power, and materials in the world of industry. Under the urgency of our present need, these electronic devices are being used in ever-increasing quantities. After peace has come, we, as consumers, will reap the benefits of these speed-ups of production.

The American standard of living has been raised to its high level by mass production, with its slogan of "better, faster, cheaper." Many of us can remember back far enough to compare the prices of the first automobiles, radios, and electric refrigerators with those of today. Time was when only the town's richest man had any one of them, and when he got it the neighbors gathered to view his treasure. But the slogan of "better, faster, cheaper" has put them all within the reach of the average man. 


\section{IX}

\section{NEW TELEVISION AND RADIO $S E R V I C E S$}

"How мuсн longer will television be "just around the corner'?" Many of us have been a little puzzled about the extremely slow development of this field. As far as the layman is concerned, there seems to be no reason why television sets should not have been manufactured on just about the same scale as radio sets prior to America's entry into the war.

A glance backward over the progress of radio will reveal one or two surprising facts about this, however. Radio was "just around the corner" in $188_{3}$ when Thomas Edison discovered that there was a one-way flow of electricity through the vacuum in an electric-light bulb. Radio seemed to draw nearer when in $1903 \mathrm{~J}$. A. Fleming developed the diode, a two-element vacuum tube which could turn alternating current into direct current. Radio seemed to have turned the corner when in 1907 Lee de Forest developed the triode, or three-element tube with the grid-the very heart of radio. But when the first World War drew to a close in 1918 radio was still "just around the corner." Not until I92 I did station KDKA inaugurate broadcasting. Even then the situation seemed none too promising.

Briefly, there was a lapse of more than forty years between the discovery of the factors that form the basis of radio transmission and the manufacture and sale of radio sets for general use by the public. To be sure, a long period of education 
was essential; and this would not necessarily be the case with television. But there are certain fundamental differences between radio transmission and reception and the transmission of television that alter the problem.

In order to understand the problems of bringing television to the homes throughout the length and breadth of America, it is important to grasp the difference between transmission of the radio waves used to transmit sound radio today and the high-frequency waves which are used to transmit television. Radio waves at a frequency of from five hundred and fifty to fifteen hundred kilocycles can travel great distances because they are reflected back from the ionosphere, a layer of charged particles which encircles the earth. While the "ground waves" from a radio station might travel in a straight line from the transmitting antenna thirty or forty miles, these "sky waves" which are reflected may shoot out into space two hundred miles or more; strike the ionosphere; and be reflected back to earth several times, traveling halfway around the earth or even farther.

But the waves at the frequencies used to transmit television are not reflected back to earth. They travel in a straight line, so that they can be sent only as far as one can see from the antenna which is transmitting them. Of course, the higher the antenna the farther the waves can be sent. But even from the highest antenna available today, television reception cannot be depended on farther away than an area fifty miles wide around the transmitting station. We know that the networks of sound-radio stations are hooked up by telephone lines. But telephone cables cannot transmit television in a satisfactory manner. The only type of cable which is satisfactory is a type called "coaxial," and the expense of laying but one coaxial cable across the continent would run into millions of dollars. 


\section{Television Service in England}

In England, where distances are not such a barrier to coverage of the country with television, there had been some very interesting developments up to the time of the present conflict.

F. W. Camm ${ }^{1}$ reports that the B.B.C. first incorporated television transmission in its programmes in August of 1932. Before that date the only programmes were those transmitted from the Baird Company's transmitting station at Long Acre, London. They passed by land-line to Savoy Hill (2 LO), and thence to Brookman's Park. Later a studio was specially set aside at Portland Place (Broadcasting House) for television programmes on the Baird System.

Mr. Camm tells of another fascinating development of television, which is called "noctovision":

"Another development of television is to be found in the utilization of the infra-red rays for the illumination of the subject being televised or transmitted. As is well known these rays are invisible, and they are already frequently employed in burglar alarms, etc. If, therefore, the object to be transmitted is placed in a darkened room, and is scanned by means of infra-red rays, the light variations would still be recorded by the photo-electric cells and the image could be transmitted, even though in complete darkness. This opens up possibilities of seeing by night and a use for television in times of war is thus produced."

\section{Television Prospects in America}

It is reasonable to expect that after the war we will see a sudden expansion of the manufacture of television sets. As James Stokley expressed it, "It is to be expected that the dis-

${ }^{1}$ Camm, F. W., Television Manual. New York, Chemica: Publishing Company, 1943 . 
tribution of the television transmitters doubtless will follow the general pattern of population distribution in the United States. This population may be considered as centered principally in 96 metropolitan areas set up by the Bureau of the Census having 100,000 inhabitants or more. . . .

"These 96 metropolitan districts are usually taken as the basis of marketing plans. Although they comprise only $\mathbf{1 . 2}$ per cent of the land area of the United States, they contain 45 per cent of its population. Assuming the maximum service area of a television transmitter to be 25 miles in radius, however, we find that 96 such transmitters (one in each metropolitan district of the United States) would lay down an adequate signal over 6 per cent of the land area and more than 50 per cent of the population.

"To choose an obvious example, New York is the first city of the United States to have regular television service intended for the public. The metropolitan district surrounding $\mathrm{New}$ York comprises 8.9 per cent of the nation's inhabitants, 63 per cent of the population of New York state, 72 per cent of New Jersey's inhabitants, and 9 per cent of Connecticut's. Chicago's metropolitan area includes 3.6 per cent of the population of the United States and 57 per cent of the population of the state of Illinois.

"In the 1927 television days, one experimenter said, 'If we can tell a face from a fish, we think we're doing pretty well!'

"Modern television, which is now being broadcast and received by a small number of sets from a handful of transmitters in a few cities, is a vast improvement, and is approximately equal in quality to good home movies. In 1941 the U. S. Government finally authorized commercial operation of television stations, but the advent of the war, and the cessation of the building of civilian radio receivers, halted the development which otherwise would then have come. However, experimentation did not entirely cease; some continued 
with war applications as the goal, so that after the peace television should be ready for a rapid enlargement, which will undoubtedly far surpass that of sound broadcasting in the post-World War I days."

According to Mr. Stokley, televised moving pictures in America have successfully utilized the device known as the Schmidt camera. He says, "At the New York demonstration, the projector was sixty feet away from the screen, yet the picture, fifteen feet high and twenty feet wide, was almost as bright as an ordinary motion picture. Perhaps, in the future, with such a device, theatres will regularly show programs of events happening in other parts of the world, at the same time that they are occurring."

\section{The Actor Comes into His Own}

Mr. Lenox R. Lohr gives a very interesting picture of the "behind the scenes" problem of broadcasting television drama, as compared with sound broadcasting and play production in a theater: ${ }^{1}$

"In first-class theatre productions, at least several weeks are allowed for rehearsals before the opening night, but the cost of television obliges a producer and actors to prepare a 30- or 6o-min. performance for broadcasting in 5 to $20 \mathrm{hrs}$. of rehearsal.

"Another requirement of television production makes it difficult for sound-radio actors to appear on programs. Television actors must learn lines by heart; and although radio actors are skilled in the subtle shading of words, they have not learned to coordinate words with action. By no rational process can we adapt the usual microphone technique to television, because in television, as on the stage, we must follow

${ }^{1}$ Lohr, Lenox Riley, Television Broadcasting. New York, McGraw-Hill Book Company, Inc., I940. 
Shakespeare's prescription and 'suit the action to the word.' Even actors trained for motion pictures find it necessary to adapt themselves to television.

"In motion pictures, the action is shot scene by scene with convenient intermissions. The director rehearses his cast until he is satisfied with its performance. The actor need not memorize lines for more than one or two scenes at a time. After shooting a long succession of scenes, the final picture is assembled by editors in the cutting room. The actors themselves seldom realize the full scope of the action until they have seen the completed picture on a screen.

"In television, the actor must know his lines verbatim before he steps up to the camera. There are no interruptions or pauses in a television performance. There are no retakes, such as may occur in motion pictures to achieve an improved performance. In television, if a mistake is made it must be 'covered up' quickly and naturally. This requires considerable adroitness on the part of the actors. When the show is under way, the player is on his own, for better or for worse; and if he forgets his lines, he must improvise. In television, it is hard to prompt a stumbling actor. The producer sits in the control booth behind a plate glass window, and the only way he can reach an actor is through the studio manager with whom he is in telephonic communication. The actor must shoulder the responsibility of making a scene continuous. ..."

Mr. Lohr believes that one of the most significant fields of television broadcast will be in educational and news broadcasts:

"Such material has contributed much to the success of sound radio, but introduction of long verbal dissertations soon tires the most patient listener. Television promises to offset this serious handicap to a large extent, because it broadcasts animated pictures that illustrate ideas more rapidly and effectively than words. 
"In attempting to illustrate radio news with pictures, we are prone to follow the technique developed by such news magazines as Life, The Illustrated London Nerws, and L'Illustration. . . . Pictorial news broadcasting may in time become one of television's most important public service functions. For here the program staff has at its disposal the means of depicting history exactly as it takes place. No matter if a news broadcast is unrehearsed and even if it appears amateurish, the ingredients of drama and interest are present to a large degree."

In summarizing the probable future of television development in America, Mr. Lohr said:

"The prices of the receivers were admittedly high. They ranged commonly from $\$ 175$ to $\$ 700$ in the early months; at the time of writing there seems to be a trend toward reduction of them. A price of $\$ 125$ to $\$ 250$ is within range of many families whose income is less than $\$ 2,000$ a year, but such families are reluctant to part with so substantial a sum unless there is reasonable assurance that the receiver will not become obsolete rapidly.

"This question of the cost of receiving sets is the basic factor in obtaining 'mass circulation' for the broadcaster. The necessarily high cost of the receiver-the technical equivalent of about three first-class broadcast receivers-can not be reduced without painstaking effort. However, assembly-line methods, a supply of used receivers, and the effect of competition in bringing down the cost of television sets may be counted on to make sets widely available in the not-toodistant future. The problem is, of course, to market the receiver at a price within reach of a large number of buyers, to gauge the market accurately, and to keep factory capacity geared to the demand for receivers."

Mr. Lohr takes a very levelheaded view of the possibilities 
of rapid expansion of television, and his words of 1940 are equally applicable today:

"Sales areas for television receivers must be governed entirely by the distribution of television transmitters. The limited range of television transmitters also definitely limits the extent to which the entire country can be considered a television market."

\section{The Fighting Man's "Nerve Center"}

Today many peacetime industries have ceased to function. Not so the radio industry. Radios for civilian use are not being built. There are no new designs in cabinets coming out at the moment. But that is the only type of radio equipment which is not being built. The "engine" of the radio-the chassis that is housed in the cabinet-and all the parts which go to make up the "insides" are being built in quantities undreamed of before the war.

For the nerve center of fighting equipment today is the radio, and the vast amount of radio equipment used by our armed forces is almost beyond comprehension. Every plane that rolls off the assembly line; every tank, every jeep; every battleship, cruiser, submarine, and PT boat-each needs its radio equipment. The foot soldier has his "walkie-talkie" and the paratrooper his "jumpie-talkie."

Even the rubber life rafts of the airplanes are now being equipped with radios. Sappers use radio devices to detect the presence of mines, so that fields can be cleared of those deathdealing machines before they can play havoc with our advancing forces. There is a portable radio station which can be buried on a hostile shore and left unattended. For weeks on end it will faithfully transmit information about the weather, to help our forces plan a surprise landing at the right time. 
Therefore, radio equipment-though it is not being supplied for civilian use-is being built for the Signal Corps, more than three times as much of it every month as was ever built in peacetimes!

\section{Indestructible Radios for the Armed Forces}

Not only is it being built in these tremendous quantities, but it is being built with a durability never demanded in peacetime equipment.

The motto of the Signal Corps is "Get the message through!" Today our soldiers must get the message through with radio equipment-and do it under conditions which would put a peacetime radio out of commission in ten minutes.

Suppose you dropped your radio into the bathtub on Thursday, left it there overnight, put it in the oven Friday morning and baked it, put it in the electric refrigerator on Saturday and turned the cold controls on so high that everything in the icebox became a brittle stick. And then, on Sunday, suppose you took your radio for a ride in a jeep, and dashed madly through a town where "block busters" were exploding with force enough to shatter windows a mile away. As you jounced and jolted through the town, over shell holes that had been streets, would you expect to tune in your favorite symphony? Would you demand that every note be clear as a bell?

But the Signal Corps must get the message through under conditions such as these. On battleships, when the "kick" of the huge guns is sufficient to shove the vessel sideways through the water as you'd shove a cake of soap in a washbowl, radio equipment of precision and delicacy must function all day and all night and the next day too. And it must not fail.

On smaller craft, hurtling through the seas with mountains 
of salt water crashing over their decks, radios must not fail.

In'Flying Fortresses, where a crew of men must function as one with split-second timing, communication among them must not fail.

If your favorite radio serviceman were in Cuba instead of around the corner, you'd want the durability of Army radio equipment in your peacetime radio. You'd know that if your radio "went bad" you'd lose your favorite programs for too long a time. The radios of our soldiers often must operate far from the nearest serviceman. And if a soldier's radio goes bad it may cost his life.

For the radio today is not only the nerve center of military strategy; it is the life line of safety. Many of the most brilliant developments of today are designed to save the lives of our men.

\section{Radio Safety Devices}

The blind-landing instruments have saved the lives of countless flyers. A fighter plane, returning from a mission, speeds through the black night at five miles a minute. The pilot flicks a switch. A vertical hairline crosses a dial toward a center mark-and passes that mark. Off course a bit. The pilot changes his course until the hairline is exactly on the center mark. He's on course now, heading for home. But how far away is he? That is a crucial question when you're covering five miles a minute. A light on his dashboard flashes. He has passed a marker beacon. Twenty miles to go. He cuts his speed. Another light flashes. Five miles. If there were a light on his landing field, he could see it. But there is no light. He hurtles into black nothingness. Suddenly a horizontal hairline appears on the dial and climbs toward center. He smiles. He's reached his "glide path" now. A little high-he'd overshoot his mark. He brings the nose down a bit. The horizontal line 
wavers, and then stops on the center mark of the dial. He's on his glide path now. Nothing to do but hold the plane there. Just as a child slides down a sliding board, the pilot glides down an invisible incline, made by a radio beam, and sets his plane down on the runway as smoothly as a motorist would drive into his familiar driveway in broad daylight.

Today the total output of perfected blind-landing equipment may go to our military needs. But tomorrow such developments will add to the safety of civilian flight.

Today the absolute altimeter warns our fighter planes of just how high aboveground they are. Tomorrow civilian planes will be equipped with this lifesaving device, and collisions with mountains will be prevented.

Today the radio detector, Radar, "sees" a submarine a hundred miles away, and directs the bomber on its course to sink the submarine. Tomorrow that same radio detector will enable a searching plane to find a disabled vessel or a lifeboat a hundred miles away, at night, and will direct the searchers to the spot.

The exigencies of war have compelled the best brains of the radio and television fields to think faster, harder, more carefully, than ever before. Future developments in these fields will be based upon the phenomenal achievements of the past thirty months.

\section{$A$ Word about Frequencies}

Since radio plays such a vital part today, and is destined to play even a greater part in our peacetime world of tomorrow, it behooves us all to have some idea of "just how radio works." Hence the following explanation is offered to explain it briefly, in its simplest terms.

When we speak of sending music or pictures by electricity through wires or through space, we do not mean that the 
actual sound or picture travels through the wires or through the air. Electric current travels through wires; radio waves travel through space. The sound or picture which is to be sent to some distant point by wire must first cause a variation in electric current. It is this variation in electric current which is sent through the wire. Likewise, a sound or a picture which is to travel by radio waves through space must cause a variation in those radio waves. It is this variation which travels through space.

When we talk into a telephone, we make sound waves that travel through the air and vibrate against a metal disk, moving it. This vibrating disk, in turn, affects electric current, which varies in time with the vibrations of the disk. This varying electric current travels through the telephone lines. At the receiver on the other end of the line, the action is reversed. Here the electric current (which is varying in time with the disk against which we spoke) affects a second disk in the receiver and sets it in motion. This second disk, vibrating in time with the variations in the electric current (and consequently in time with the first disk), starts sound waves through the air. These sound waves which reach the ear of the listener are the exact repetition of the sound waves which made the first disk vibrate.

The transmission of sound by radio is similar to the transmission of sound by telephone. First the sound waves vibrate against a microphone and set it in motion. This vibration of the microphone causes electric current to vary in time with the vibrations of the microphone. These variations in the electric current are used to vary or "modulate" the steady alternating current which is alternating at the "frequency" on which that transmitting station broadcasts. Most of our stations today use A.M., or "amplitude modulation," varying the "size" of the wave. The F.M. stations use "frequency modulation," varying the frequency of the wave. Whether A.M. 
or F.M. is used, the "carrier" wave is transmitted from the antenna, varied or "modulated" in time with the variations of the microphone, just as the electric current in the telephone lines varies in time with the disk in the mouthpiece.

At the "receiver" in our homes (just as at the receiver of a telephone) the process is reversed; the variations on the carrier waves (which are exactly "in time" with the vibrations of the microphone back in the studio) affect the cone of the loud-speaker on our radio receiver, and it vibrates in time with those original vibrations and sets up sound waves which repeat the original sound.

\section{Sending Pictures by Radio}

When a picture is sent by wire, again we have the steps of varying or modulating electric current in time with certain elements in the picture and, at the receiver end, of turning these variations into the picture again. When a picture is sent by radio, we vary or modulate the carrier wave at the transmitter in time with certain elements in the picture; at the receiver we "demodulate" the carrier wave, or take these variations from it again and turn them back into the picture.

To understand the principle of television, examine a photograph in a newspaper through a reading glass. You'll note that the "picture" is made up of a series of dots. The coarser the dots, the less distinct the picture will be. The finer the dots, the clearer the picture will be.

If you were going to send this picture by radio, you would "scan" the picture with a beam of electrons, beginning at the upper left corner, crossing the picture to the right side, moving down one row of dots and crossing the picture again, and so on until you had "scanned" every row of dots from top to bottom. Now if the dots of the picture could cause electric current to vary, just as the vibrating disk of a microphone, 
and you "modulated" a carrier wave with these variations, you could transmit the variations of dots in the picture just as you transmitted the variations of the sound. If your receiver contained a device which was in time with, or "synchronized" with, the back-and-forth movement of the beam that scanned the picture, you could repeat the picture on a screen in your receiver, a dot at a time, just as it was picked up from the transmitter, a dot at a time.

If you have read the chapter on electronics, you will recall the photocell-a vacuum tube which contains a material that will emit electrons when light falls on it. The iconoscope, a tube that is used in television to transmit pictures, contains a screen made up of thousands of tiny photocells, each no larger than the dot in the photograph you looked at in the newspaper. The picture to be transmitted is focused on the screen, just as you focus a picture on the film in your camera. As the picture is focused on the screen, the tiny photocells emit electrons-the number of electrons each cell emits depending on the brilliance of the light or the density of the shadow which is focused on it. The more electrons a cell emits, the more positive becomes its charge.

We might compare the screen of cells at this point with a newspaper picture and say that these little cells, with the variations in positive charge that they have, are the electric black dots and white spaces of a newspaper picture.

Then from an "electron gun" a stream of electrons scans the picture, a row at a time, and each little cell reacts in accordance with the amount of positive charge it now has. The variation of each cell is used to modulate the carrier wave which is transmitted from the television broadcasting station, just as the variations in electric current from the microphone vary the carrier wave for a sound broadcast.

At the receiver another electron gun flashes back and forth across a screen which "fluoresces" or lights up in accordance 
with the varying number of electrons which reach it. When the original variations on the carrier wave are fed to the electron gun in the receiver mechanism, the number of electrons emitted from it varies "in time" with the variations in the reactions of the electric black dots and white spaces of the original picture, and the picture is repeated on the receiver screen, a dot at a time, just as it was picked up from the transmitter screen.

Why do we see a complete picture and not a dot at a time? Because the electron gun scans the picture so rapidly, going from left to right and from top to bottom so fast, that it makes a complete picture in one-thirtieth of a second!

Most of us are familiar with the principle of the motion picture. We have looked at a "strip" of film, seeing picture after picture with changes so slight that it is hard to detect these changes unless we look at quite a long strip of film. "Movies," as we know, are possible because the human eye cannot see fast enough to distinguish the different pictures when they are flashed on a screen at a speed of more than sixteen different pictures, or "frames," a second. Therefore we see, not different pictures, but a continuous flow of action.

Television, too, flashes complete pictures, or "frames," on the screen of a receiver too fast for us to distinguish the different pictures. It flashes thirty "frames" a second, although it must flash each frame a dot at a time! If the picture were four hundred dots high and five hundred dots wide, the beam of electrons scanning the picture would cause two hundred thousand variations in the electric current in scanning the picture once. In sending moving pictures by television, to send thirty complete frames a second the electronic beam would vary the current six million times a second!

There we come to one great difference between television broadcasting and our everyday sound broadcasting. We do 
our commercial broadcasting on a "band" of frequencies 950 kilocycles wide-from 550,000 to 1,500,000. Each station transmitting sound programs is assigned a fixed frequency somewhere within this band and is given a "side band" on each side of the fixed frequency, which is five thousand cycles wide-or a band ten thousand wide in all. Our commercial sound broadcasting allows room for ninety-five such bands each ten kilocycles wide. But what can we do with a television "band" from four million to six million cycles wide? Our whole sound broadcasting range cannot accommodate one such station! To try to handle television on our commercial sound frequencies would have the general effect of trying to drive a ten-ton truck through a cottage door.

These, then, are the problems and potentialities of the development of television tomorrow. The potentialities are truly miraculous. The problems are vast; they are the problems of handling the higher-frequency waves. Equipment must be engineered to handle them; coaxial cable must be provided to carry them. But the production of today is solving those problems for us. High-frequency equipment is being designed and built in vast quantities, by mass-production methods. That production and the equipment to continue it will be ready to serve our peacetime needs tomorrow. Therefore the future of television is bright.

What of F.M.-frequency modulation? In two years it has had an astounding growth. Stations broadcasting with frequency modulation expanded from one station to forty-five stations, in that length of time. F.M. receivers-half a million of them-are in use today. And their delighted owners know a beauty and fidelity of reception, and a freedom from static, that A.M. receivers seldom approximate. Here, too, mass production of equipment engineered to work on the frequencies used in F.M. will be ready to serve us tomorrow. 
So the most conservative engineer will admit that the future of radio is full of miracles. Tomorrow our "main" radio will probably be a combination set-A.M., F.M., phonograph, and television screen. And mass production will quickly change it from a luxury of the few to a pleasure of the many. 


\section{$\mathrm{X}$ \\ CHEMISTRY MAGIC}

The Discoveries made in developing plastics during the past three years have increased this nation's potential wealth beyond any possible calculation. As early as 1940, industry had created plastic substances that were as thin as tissue, as fine as silk, as elastic as rubber, more transparent than glass, lighter than wood or aluminum, and tough enough to stop bullets. Far from being mere substitutes for critical materials, these plastics are proving as good or better than the materials they replaced.

Plastics-synthetic (man-made) materials that can be molded into permanent shapes-have gone to war in a big way. John M. Wetherby of the Society of the Plastics Industry pointed out that prior to the outbreak of war the plastics industry had concerned itself mainly with the production of such everyday things as electrical appliances, radios, parts for automobiles, decorative buttons, and hundreds of similar items designed for eye appeal and general civilian well-being.

Yet when the armed forces outlined their needs, plastics were quickly put to work to replace both scarce metal and rubber in war equipment. Plastics are used for pistol grips and bayonet handles. This material will stand cold of 40 degrees below zero without cracking and heat of 170 degrees above zero without softening or blistering. Plastic linings also are used in combat helmets, and for goggles to protect a soldier's eyes against the glare of desert sands or Arctic snows.

"While all the present uses of plastics cannot be detailed, for obvious reasons," states Mr. Wetherby, "some idea of the 
part which they are playing in our war effort may be gleaned from the fact that each of our new battleships incorporates well over I, ooo different plastic applications. The wide use of these materials in our aircraft is already pretty generally recognized, ranging all the way from the plastic bomber nose of high optical and aerodynamic qualities to the plastic bonded plywood fuselages and wings used on glider, trainer and freight-carrying planes. Today more than 200 different aircraft parts are being made from plastics and more are under development."

He added that plastics not only were proving desirable alternatives for scarce metals where great strength and toughness is required but also were being used to advantage in applications formerly associated with rubber, wood, and glass. Growing military demands have greatly reduced the supply of certain plastics for civilian use. One of the most critical of the plastic materials is jewel-like methyl methacrylate, which is probably best known for its application in bomber noses, navigator domes, and cockpit enclosures. Mr. Wetherby said production of this plastic has been stepped up, but it is doubtful whether the civilian will get much of it until the war is over.

A lot of other materials formerly used by civilians have disappeared faster than a person can say methyl methacrylate. But the new alloys, plastics, and chemicals that are giving the United States the world's greatest fighting machine will make this nation a better place to live in when the Axis has been put out of business.

"Chemicals are essential raw materials," explains Dr. Emil Ott, research director of the Hercules Powder Company. "Today we use them in planes, tanks, ammunition, and to relieve war shortages. This war research is providing a vast storehouse of basic knowledge. Tomorrow we will use what we are learning about these essential chemicals for civilian 
planes, automobiles, houses, food, machines, clothing, cosmetics and thousands of other every day articles."

\section{Precious Synthetic Rubber}

The dozens of products now being made by our huge synthetic-rubber industry should perhaps be called "soft plastics," according to Gerald Wendt, science editor of Time magazine. Natural rubber, he adds, is but one of the soft plastics, as natural rosin and amber belong among the hard plastics. "Whether natural rubber will occupy a larger place among them than amber and rosin do among the miraculous, tailormade, hard plastics will appear within the next decade," he concluded.

In June, 1943, Rubber Director William M. Jeffers promised that synthetic-rubber plants would produce 250,000 to 275,000 tons of rubber in 1943 . He added that by the first quarter of 1944 production at an estimated rate of 850,000 tons a year, far in excess of imports of crude rubber, will be reached. The crude-rubber production of the world amounted to a million tons yearly, but our chemists will produce almost that much in less than two years.

Chemists will get more rubber from 40 acres of factory space than rubber growers could get from 50,000 acres of plantation. One synthetic-rubber plant with a rated capacity of 90,000 long tons of rubber a year will match the output of a 270,000 acre plantation. Such a plantation would have more than 24,000,000 trees and need at least 90,000 workers. It would cost about $\$ 80,000,000$ to bring such a plantation into production. The one synthetic-rubber plant used in this example cost $\$ 56,000$,000 and is operated by only 1,250 men.

The general-purpose synthetic Buna $S$ was selected for the greater part of the nation's synthetic-rubber program. "It isn't rubber," said H. B. Pushee, chief chemist of General Tire \& 
Rubber Co., "but it's the best substitute we have." Others agree that Buna $S$ is the synthetic most similar to natural rubber in processing and performance characteristics. It may be vulcanized with sulphur and rubber accelerators and cured to hard rubber. Its resistance to atmospheric deterioration is slightly higher than that of natural rubber. Buna $S$ has been found satisfactory for use in passenger tires, without the addition of natural rubber. Although coarser and rougher than natural rubber, Buna $S$ has no offensive odor (only a faint tarry odor). When the first Buna $S$ tires hit the market in I 944 the motorist will be unable to tell the difference between them and the prewar natural-rubber tires.

On heavy-duty tires Buna $S$ must be mixed with natural rubber to get best results. Thirty per cent of natural rubber is used for heavy-duty treads and carcasses and about ro per cent for the tire tubes.

\section{How Synthetic Rubber Is Made}

The word "buna" was first used in Germany- "bu" standing for butadiene and "na" coming from natrium, the classical name of sodium. The letter S stands for styrene. Buna $\mathrm{S}$ is a copolymer produced by the polymerization of approximately three parts of butadiene with one part of styrene. Let us start at the beginning and translate that sentence into nontechnical terms if possible.

A monomer is a material composed of molecules corresponding to the individual units of a polymer.

A polymer is a giant molecule formed when hundreds of thousands of the original molecules of the material have been linked up together end to end like boxcars in a train. This linking together, or polymerization, gives a rubberlike material its bounce, elasticity, and resiliency. Natural rubber is a polymer of a single material called isoprene, but most syn- 
thetic rubbers are copolymers of two or more ingredients mixed in such proportions as to give them rubberlike characteristics. Thus a copolymer is a giant molecule formed when two or more unlike monomers are polymerized together. Chemists explain that, if a polymer is like a long train of boxcars, a copolymer is mixed freight-boxcars and tank cars alternating in any proportion, such as three boxcars and one tank car (which is the case of butadiene and styrene in Buna $S)$.

Buna S is called GR-S by officials; the "GR" means simply "Government Rubber." Here is how it is made. Butadiene, a complex gas composed of hydrogen and carbon (obtained from petroleum or alcohol from molasses, corn, or other grains), is mixed with styrene (from coal tar or from petroleum) in a solution of soapy water. They form a milky liquid latex, similar to that of natural rubber. With heat and the addition of a catalyst (an agent that speeds a chemical reaction without being affected itself) the minute droplets are stirred until they change into solid rubberlike particles of Buna S (GR-S). The particles (flox or crumbs) of synthetic rubber rise to the surface of the solution and are screened off. Then they are washed, the excess water is pressed out, and the material is dried and pressed in seventy-five-pound bales.

\section{Bless Jobn Barleycorn}

There was considerable controversy in 1942 over whether petroleum or alcohol from agricultural products was best for the production of butadiene in the Buna $S$ program. As the program got under way, alcohol proved to be the quickest way to get the synthetic rubber because there were plenty of stills, mostly whiskey, ready to produce it, while the petroleum industry had to build special equipment. Chemists agree, however, that petroleum alcohol in the long run will prove to 
be better than grain-made alcohol for the production of butadiene. Alcohol made in oil refineries will cost much less than that from grain.

Buna $S$ is being produced in several plants operated for the government by the United States Rubber Company, Firestone, Goodrich, and Goodyear. Here are some of the synthetic rubbers that have important places in our program: ${ }^{1}$

Buna $\mathbf{N}$ type, copolymers of butadiene and acrylonitrile. They include the following: Perbunan (Standard Oil Company of New Jersey and Firestone Tire \& Rubber Company); Hycar (Hycar Chemical Company, owned by Phillips Petroleum Company and B. F. Goodrich Company); Chemigum (Goodyear Tire and Rubber Company); Thiokol RD (Thiokol Corporation, associated with Dow Chemical Company).

The Buna N's are similar to rubber in being vulcanized with sulphur and rubber accelerators, and may be cured to hard rubber; but in some operations they are harder to handle than natural rubber. They are used principally in oil and gasoline hose, tank linings, packings, gaskets, printers' blankets, and other products where resistance to oil is important (such as oil-resistant soles and heels).

Neoprene, a polymer of chloroprene. It was introduced by the Du Pont Company in 1932 under the name Duprene and proved to be the first commercially successful synthetic rubber. It is a good general-purpose rubber with good resistance to chemicals and oil and excellent resistance to heat, air, and light-better, in fact, than any other rubber. It is harder to handle, however, than natural rubber or the Bunas in certain operations. Neoprene is used for truck and bus tires, inner tubes, footwear, shoe soles, sheet goods, and many other industrial and general purposes.

${ }^{1}$ On November 9, 1943, the United States Rubber Company announced the development of uskol, the sixth major type of synthetic rubber to be discovered. It has great resistance to oils, fuels, solvents and other penetrating chemicals. 


\section{"Batbtub" Rubber}

Butyl rubber, a copolymer of isobutylene and small amounts of other unsaturated hydrocarbons such as butadiene or isoprene. Flexon, a modification of this type, is called "bathtub butyl" because it can be made with comparatively simple equipment. Butyl is spoken of as "an ace in the hole" in our synthetic program, and could be produced at low cost quickly from abundant materials to replace natural rubber in many applications. Standard Oil of New Jersey controls the process. Butyl's general resistance to deterioration is good, but its physical properties are lower than those of natural rubber. It may be used to advantage in applications where resistance to chemicals and oxidation (it is one of the few materials resistant to the poison gas lewisite) are more important factors than tensile strength and elasticity.

Thiokols of types A, B, and FA, made from ethylene dichloride and sodium tetrasulfide or from dichloroethyl ether and sodium tetrasulfide or from modifications and combinations of the two. They were developed by the Thiokol Corporation and are now being manufactured by the Dow Chemical Company for the Thiokol Corporation, which handles the sale. (Thiokol RD, a Buna $N$ synthetic rubber, must not be confused with this group of Thiokols.) The Thiokols have better resistance to aromatic hydrocarbons (such as benzene, naphthalene, and toluene, which cause rubber to swell and deteriorate) than natural rubber or other synthetic rubbers. They do not, however, have as high physical properties as the other synthetics. Where resistance to deterioration is more important than resilience, tensile strength, resistance to abrasion, and extremes of temperature, as in certain industrial uses, the Thiokols have been successfully substituted for natural rubber. 


\section{Syntbetic Rubber Is Here to Stay}

Will synthetic rubber drive out and take the place of natural rubber when we have won back the Far Eastern plantations from the Japanese? If the war should end at an early date, natural rubber probably would return to its former position, since synthetic rubber will not be sufficiently developed by that time. A longer war might permit the development of synthetic rubber to a point where it could compete successfully. And in case of a very long war the synthetic material would be improved to a point where it would be better and cheaper than natural rubber.

Chemists say that Buna $S$ now costs less than thirty cents per pound and they expect to cut this to ten or fifteen cents in a few years, as compared with the ten-year average of twelve and four-fifths cents a pound for natural rubber in the New York market from I93 I through 1940. They expect the synthetic's greater resistance to acids, oil, sunlight, and other corrosive agencies to win it a big market regardless of what happens to natural-rubber prices.

\section{Untapped Resources in Natural Rubber}

"What, then, of the Far Eastern plantations?" asks the New York Times. "Will natural rubber go the way of natural indigo? Salvation lies in research. Though natural rubber is modified for a thousand different uses, it remains essentially the same. Suppose that the milk of the tree were chemically treated as, for instance, coal is treated for the extraction of chemical values. New life would be breathed into an industry on which millions depend for a living. Homologues of rubber could probably be devised which would be just as good and cheap as the synthetic varieties. Compounds could be 
won which would compete with those of the coal-tar industry. In a word, the history of petroleum would be repeated."

\section{An Exploit of the Century}

Dr. Charles M. A. Stine, vice-president of E. I. du Pont de Nemours and Company, promises that "the newest and most versatile of plastics will be available after this war on a scale beyond all previous conceptions. The high-pressure synthesis of ammonia, one of the major chemical exploits of the century," he asserted, "will have taken on an industrial status that, in terms of new producing capacity, may be comparable to the discovery of a sixth continent.

"The amount of fertilizer chemicals that this new capacity will be able to supply farmers will be so large that the trends of agriculture might be changed.

"And these are," he continued, "but one group of a hundred or more products stemming from this high-pressure synthesis, which utilizes air, coal and water as its building blocks. We will have glass that is unbreakable and glass that will float, wood that won't burn and laminations of plastics and wood that will compete with structural metals.

"Hosiery derived from air, water and coal, a wonder of prewar days, is but the forerunner of many innovations from the same source, ranging from shoes that contain no leather and window screens that contain no wire to machinery bearings that contain no metal.

"Today we produce to destroy, but tomorrow we will produce to build. Give us a victorious peace and the freedom of enterprise it should guarantee, and our progress will be unprecedented. Let our swords be mighty and mighty indeed will be our plowshares," he concluded. 


\section{Fabulous New Wealth}

Chemistry has ninety-two basic elements to work with in making the thousands of useful articles in the world today. Of the ninety-two elements twelve alone make up more than 99 per cent of the known parts of the earth-the atmosphere, the earth's crust, and the ocean. Oxygen and silicon, which occur mainly as silica or silicon dioxide in sand and quartz, are by far the most widely distributed. They form together about three-quarters of the materials of the earth's surface. Aluminum is the most common metal, occurring in granite (feldspar) and in clay. Carbon, which is the chief element in substances associated with living things, forms less than .02 per cent of the material of the earth's crust.

\section{The Great Compounds}

Analysis of certain compounds-such as cellulose $\left(\mathrm{C}_{6} \mathrm{H}_{10}\right.$ $\mathrm{O}_{5}$ ), the chief organic compound in wood pulp and cotton; ethyl alcohol $\left(\mathrm{C}_{2} \mathrm{H}_{5} \mathrm{OH}\right)$, the active principle in intoxicating liquors; eugenol $\left(\mathrm{C}_{10} \mathrm{H}_{12} \mathrm{O}_{2}\right)$, which gives cloves their taste and odor; and vinegar, which is dilute acetic acid $\left(\mathrm{CH}_{3}\right.$ $\mathrm{CO}-\mathrm{OH}$ )-establishes this important fact: all are composed of just three elements-carbon, hydrogen, and oxygen-but a complicated arrangement of the atoms of these elements into molecules produces the different compounds above.

There are hundreds of such compounds. In fact, the compounds of carbon total anywhere from 225,000 to 500,000, while the known compounds of all elements other than carbon amount to no more than twenty-six thousand. Organic chemistry, the study of the compounds of carbon, touches every phase of our modern civilization. The cell, which is the unit of all living matter, is made up of compounds of carbon. Our food, textiles for clothing, wood for furniture and 
buildings, paper, gasoline for our automobiles, and thousands of other materials-such as dyes, medicines, drugs, perfumes, soaps, rubber, and explosives-are all carbon compounds.

\section{The Super-super By-Product: Coal Tar}

For many years man has sought to take nature's productscoal, water, wood, cotton, petroleum-apart and then put them together again to effect a chemical synthesis. Nature herself is tops in the field of chemical synthesis. For instance, the changing of mulberry leaves, by a worm, into silk and the formation of sugar, vegetable oils, and cotton fibers from water, air, and sunshine.

When bituminous coal is heated in an enclosed vessel, it gives off gases and leaves coke (used in steelmaking) as a residue. Coal tar also is left in the tubes and containers. At first, its appearance was considered a nuisance and chemists were put to work to get rid of it. Coal tar is now the basis of the great chemical industries of dyes, modern explosives, disinfectants, synthetic perfumes, drugs, and synthetic resins.

The study of coal-tar derivatives progressed rapidly after the eighteen-year-old William Perkin produced the first coaltar dye, mauve, in 1856 . Till then the dyeing of all textiles had been carried out with plant juices like madder or indigo and with animal excretions like the ancient Tyrian purple, produced by a snail-like Mediterranean shellfish. In 1868 two German chemists synthesized alizarin (turkey red), the coloring matter of the madder plant from anthracene, and soon ruined France's madder industry. The synthesis of indigo and Tyrian purple followed in later years.

While work on the aniline colors continued, other chemists established the make-up of the simpler active constituents of medicinal herbs and made similar drugs from coal tars. Among them were salicylic acid for treating rheumatism, 
aspirin, phenacetin, and sleep inducers like sulphonal and veronal. The antiseptic properties of coal tar speeded up the search for new antiseptics, of which crude phenol, carbolic acid, was one of the first introduced, to be followed in recent years by the amazingly effective sulfa drugs. Their use on burns at Pearl Harbor against streptococcus infections and against pneumonia and other diseases has already saved an incalculable number of lives. Atabrin, vital substitute for quinine, which is used by our fighting men in the tropics to combat deadly malaria, is another coal-tar derivative. Improved anesthetics also have been made from coal-tar chemicals.

\section{$A$ Ton of Coal}

Every ton of coal coked in a by-product oven produces, on an average, 0.7 ton of coke, 0.06 ton of screenings, 10,500 to I 1,500 cubic feet of gas, I 2 gallons of tar, 26 pounds of sulphate of ammonia, 1.75 gallons of benzol, 0.55 gallons of toluol, 0.24 gallons of xylol, and 0.5 pound of crude naphthalene. These basic products can be broken down into the constituents of explosives, plastics of many types, solvents, food preservatives, insecticides, fertilizers, lacquers, "soapless soaps," and countless other things vital to the war effort now and of great utility in the future.

Toluol is considered to be the most important product recovered from coal. It is widely used during peacetime in the manufacture of rubber cement, wood stains, paints, paint and varnish remover, as a substitute for turpentine, and special inks. Today most of the toluol is being converted into TNT. Methanol, derived in part from coal, is a necessary raw material for the manufacture of certain explosives, and aniline, also obtainable from coal, is needed to make the tetryl used as a "booster" in high-explosive shells.

From benzol comes phenol-which is used with air and 
water to manufacture nylon, having a higher combined strength and elasticity than any natural fiber. Great quantities are used for parachutes and canopy cloth, shroud lines, and belting for parachutes. Tough, durable paintbrush bristles, and bristles for essential industrial and toilet brushes, now come from coal, air, and water instead of from the back of a Far Eastern hog.

A large portion of benzol will be used in the production of styrene, which polymerizes with butadiene (from petroleum) to make synthetic rubber. Coal derivatives also are combined with limestone and salt to produce neoprene, the first general-purpose synthetic rubber made in this country.

Ammonia, recovered from the by-products during normal times, is used largely in the production of ammonia sulphate for use in ready-made fertilizers. Ammonia, as concentrated ammonia liquor, is used to make refrigerating gas and in aqua ammonia for cleaning. It is employed in the manufacture of a large number of ammonium salts, such as ammonium chloride and ammonium nitrate. The heavy use of ammonium nitrate for explosives has sharply curtailed the production of this fertilizer at present.

Another coal-tar derivative, familiar to us as moth balls, is naphthalene. This can be converted into beta naphthol, the base for many dyes that are used for the dyeing of cloth for uniforms, the coloring of paints in camouflage, and the production of synthetic rubber.

\section{Oil, the Chemist's Proxy for Coal}

All these substances, and many others, do not exist, declares Lancelot Hogben in Science for the Citizen, ${ }^{1}$ because coal tar itself has unique or miraculous resources. "The reason why

${ }^{1}$ Hogben, Lancelot, Science for the Citizen. New York, Alfred A. Knopf, 1938. London, Allen \& Unwin, Ltd. 
we can put coal tar to so many uses is that when we know how the organic molecule is built up, we can generally make it from the disintegration products of any organic material."

Petroleum, like coal, consists of stores of dead organic material produced millions of years ago by the energy from the sun. Therefore, by taking the hydrocarbons of which petroleum is composed, and which are the building blocks of all organic matter, and rearranging them, the chemist can create an amazing array of useful materials. At one time the oil refinery produced chiefly lubricants, kerosene, gasoline, naphtha waxes, and fuel oil. Today the refinery is a chemical plant that hooks together giant chains of hydrocarbon molecules to produce "tailor-made" high-octane gasoline for combat planes, and also turns out products that closely resemble common natural substances such as wood, leather, or rubber.

Toluol until very recent years was a by-product of coal. Now it is a petroleum product. Butadiene and other bases for synthetic rubber are being turned out in increasing quantities. The Union Carbide and Carbon Corporation led the way in taking refinery gases, which once were wasted or reburned as fuel, and synthesizing many chemicals-such as acetylene, which is used as the base for neoprene synthetic rubber, as well as for welding metals; sulphuric acid, which has hundreds of uses as an industrial chemical; ethylene dichloride for vitamins, antiknock fluid, plastics, and insecticides; ethylene glycol for dynamite and antifreeze aircraft-engine coolant; acetone for rayon, photo film, and solvents; and formaldehyde, chloroform, ether, and many other chemicals used in solvents, dyes, plastics, finishes, and lifesaving drugs.

\section{The Plastics}

Research in cellulose plastics by the Bell Telephone Laboratories reveals many interesting properties of these curious 
materials. The molecules in plastics can be arranged in such an orderly fashion that the material will be crystal-clear, or they can be in disorder. It appears that when the molecules are in the maximum of disorder the materials tend to be soft and flexible. When the molecules are arranged in "military formation" the materials are hardest and strongest, but sometimes brittle. For instance, there are the disorderly molecules of gum rubber and the almost perfectly ordered molecules of sugar and ice, which are brittle. A balance between these two extremes gives the chemist materials of desired strength and toughness.

The oldest plastic is cellulose nitrate, first made by treating cotton with nitric acid. With camphor it made the inflammable celluloid which was molded into combs, toothbrush handles, wooden frames, and film. With alcohol it goes into finishes that revolutionized the painting of automobiles around twenty years ago.

Another one, cellulose acetate, is made by dosing cellulose with acetic acid and acetic anhydride. Like cellulose nitrate, it is thermoplastic-will soften up each time it is reheated to a certain temperature. These plastics are tough, easily curved, and more transparent than glass.

\section{The Hard Resilient Plastics}

The best-known plastics are the phenolic resins, including bakelite, and the urea formaldehydes, which are much used in bonding plywood. The phenolic resins are made by combining phenol, from coal, and formaldehyde. They are thermosetting-when hardened they stay hard forever more. They will resist solvents and other chemicals, and are used in gears that will outwear steel.

The urea resins, also thermosetting, are made by compounding a nitrogen product, urea (principal organic constituent of 
human urine), with formaldehyde. Until the German chemist Wöhler prepared urea without the aid "of man, dog or kidney," it was believed that organic compounds could be made only with the aid of a mysterious force present in the living plant or animal organism; thus the distinction between carbon (organic) and mineral (inorganic) chemistry. After Wöhler synthesized urea from inorganic sources, the term "organic chemistry" came to mean simply the chemistry of the carbon compounds.

The acrylate resins are made from various derivatives of acrylic acid, and are used not only in place of glass in airplanes but as dental material (methyl methacrylate is said to be used in 90 per cent of the dental plates made in this country). Since the acrylate resins, such as Lucite, have the odd property of making light go around corners, they are used as surgical and dental illuminating instruments. Their use for a host of household articles is out till after the war.

The alkyd resins, which are made by putting glycerin together with organic acids, go mostly into paint, lacquer, and varnish and into printing inks. The vinyl resins, from coke and limestone, are weather-resisting materials of high quality. Polyvinyl butral was formerly used as the plastic interlayer in safety glass for automobiles, and now forms the coating for Army raincoats, hospital sheeting, drinking-water bags, and other war products. It is replacing tons of vital rubber.

\section{Plastics from the Ocean}

By combining chlorine, obtained from ocean-water brines, with carbon and hydrogen atoms from petroleum, the Dow Chemical Company has produced an excellent plastic material known to chemists as vinylidene chloride and to you as Saran. It makes a thermoplastic pipe of great toughness, durability, and resistance to abrasion and corrosion. Saran will 
give good service to chemical processing plants; to oil, gas, and water companies; and to innumerable general industries. Of great importance is the fact that Saran pipe can be welded in less than one minute. A workman merely places the pieces to be welded on a hot plate heated to 350 to 400 degrees Fahrenheit. When the ends get sticky he places the pieces together and allows them to cool for ten seconds. After twenty-four hours the joint strength is greater than that of the pipe itself! Cheaper, better plumbing should be available in the future because of this plastic pipe.

The high-polymer plastics like Saran vary in physical form from clear, hard, transparent glasses like polystyrene to soft, elastic, film-forming materials and rubberlike products that can be vulcanized. Polybutene, produced by Standard Oil chemists from by-product gases of oil cracking, is used in place of crepe rubber in coatings and adhesives. Most of these plastic materials lack the bounce and elasticity of natural rubber or neoprene, but they are taking over many jobs in the industrial and military field.

The Monsanto Chemical Company produced a plastic to replace the rubber tires on industrial hand trucks and other wheeled equipment. Scientists then made the mistake of trying to test the plastic. They put it on steel testing equipment to see how it compared with rubber. Before the plastic treads showed any wear, the testing equipment gave out.

\section{Replacing Light Metals}

Tenite, a plastic made from cellulose acetate by the Tennessee Eastman Corporation, can be extruded like toothpaste from a tube, and then dries into a hard, wear-resisting material. It is replacing light metals in furniture and wall trim. Cellophane, also from cellulose, is used for containers which replace metal cans. 


\section{Plastic Bearings}

Scores of plastics have set records for toughness and versatility as "pinch hitters" for metal. Westinghouse has a laminated plastic, Micarta, which is used for the bearings of propeller shafts. A fifty-pound Micarta roll neck on a giant rotating roll supports a million-pound load. One airplane engine company saves one hundred thousand pounds of aluminum a month by substituting phenolic-plastic engine parts. These parts can be molded in one operation, instead of the five steps it took to make them from aluminum. A tough ethyl-cellulose plastic is used in making dies, jigs, and forming blocks for the fabrication of plane parts, thereby replacing scarce metals and speeding up production. It should be invaluable in making low-cost light planes. Three parts of the sixtymillimeter trench-mortar fuse are made of thermosetting plastic, which saves a pound of aluminum for each projectile.

\section{Acbieving the Impossible}

"If you don't see what you want, ask for it," says the clerk in the secondhand store.

The chemical industry has given this sales talk a newer and better twist: "If you don't see what you want, ask for it. If we don't have it, we'll make it for you."

Since December 7, 1941, our armed forces have been asking for a lot of things, and the chemical industry has delivered the goods ahead of schedule.

It has worked overtime increasing the production of highoctane gasoline for planes; synthetic rubber for the wheels of our mechanized forces; TNT for bombs; chemicals for protective coatings for military equipment; oils and fatty acids for lubrication and coatings; coal-tar derivatives, such as sulfa drugs, for medicinal purposes; dehydrated, compressed foods 
for soldiers' rations; longer-wearing, waterproof clothing for our fighting men; and literally thousands of other items.

Melamine resins, among the newest plastic material, are approved for buttons on military uniforms, and also are the basis for a new paper treatment that gives tremendous strength to paper so that it can be used for sandbags, tents, food packaging, and even clothing.

Small wonder that plastics have in short order attained the dignity of strategic or essential materials widely used in Army and Navy ordnance and aircraft; in articles for the Quartermaster, Chemical Warfare, Signal, Engineering, and Medical Corps; in Maritime Commission and Office of Civilian Defense articles, as well as in many industrial processes.

\section{Winning Chemical Leadership from Germany}

We can be thankful that our chemical industry of I94I was much better prepared for war than it was when the first World War came along. When that conflict started in 1914 only five hundred and twenty-eight workers were employed in the production of coal-tar chemicals, dyes, drugs, etc. We were importing more than 90 per cent of our dyes from abroad, mainly from Germany. Nor did we have a single plant for extracting nitrogen from the air and transforming it into the chemicals so vital in war (every shot from a sixteeninch gun requires more than one hundred pounds of this gas), to agriculture, and to industry in general. We depended on Chile for natural nitrates used in fertilizers and explosives. In most scientific fields we looked to Europe for materials and leadership.

Our chemical industry struggled successfully to gain independence from foreign products during the first World War, and during the intervening years of peace it grew powerful. 
American chemists took from Germany her leadership in coal-tar dyes and other chemicals. They captured nitrogen from the air and transformed it into compounds suitable for military, agricultural, and industrial uses. We still import some nitrates from Chile, but we no longer are dependent on foreign sources of supply for this critical material.

\section{Breaking the Japanese Camphor Monopoly}

For years we depended on natural gum from the Formosan camphor tree, of which Japan had a monopoly, for vital camphor used in medicines, photographic film, plastics, explosives, and many other products. Then our chemists produced synthetic camphor from Southern turpentine, broke the monopoly, and gave us a limitless supply of camphor at one-eighth the price Japan had wanted for it a few years before.

\section{Creating New Wealtb in Agriculture}

Scores of foods developed for military use-dehydrated, compressed vegetables, meats, and other products-will undoubtedly prove popular after the war. Chemistry also is prepared to help the farmer by using more of his products for industrial purposes. Cellulose, from wood and cotton, and furfural, from waste farm products-like oat hulls, corncobs, and rice hulls-are being used in plastics. The Ford Motor Company uses soybeans to make textile fibers for upholstery and has developed an all-plastic car body from soybeans and other farm products.

Our neighbor Brazil, with a five-million-bag coffee surplus, is cooperating with a New York firm in the fabrication of plastics from cafelite, a brown molding powder from coffee beans. Cafelite is something like bakelite and lends itself to a variety of uses. It is made wholly from coffee beans, and in 
the process coffee oil, caffein, and several chemical specialties are recovered.

\section{Syntbetic Textiles}

Rayon and nylon are the pioneers of a great number of synthetic textiles which will compete strongly with natural fibers in coming years. Your clothes will be made from coal, air, and water, and from peanuts, soybeans, tree bark, milk, and wood chips. And these chemically treated clothes will be creaseproof, waterproof, fireproof, verminproof, and even stainproof. Farewell to moths and cleaning bills!

Rayon, which now is synthesized from cellulose in cotton and wood pulp and may soon be made from corn or milkweed stalks, is the oldest of the artificial fibers. It looks and feels more like silk than silk itself, but can be fabricated into tire cord or parachute shroud lines of superior strength. Rayon fibers now are used in heavy-duty tires, self-sealing gasoline tanks, and many other war products. In addition, the diversion of the remaining silk stocks and nylon to war purposes forced rayon to supply the requirements of the hosiery industry. Present yarns are not entirely suited for hosiery, but the industry expects new developments to help it compete with nylon and other fibers. The Celanese Corporation is bringing out a new spun rayon that looks exactly like highquality worsted and will be used for men's suits. Between them, rayon and nylon are expected to put the silkworm out of business-at least as far as United States business is concerned.

Other promising fibers are vinylidene chloride; Velon, which may be perfected for men's suits; and Vinyon, a copolymer of vinyl chloride and vinyl acetate. Vinyon's low heat resistance has delayed its use in ordinary fabrics, but chemists report that they are licking this problem. Palco, a bark from 
the redwood, is used as a wool blender in blankets, heavyduty coats, and felt hats. Combinations of rayon and wool and of peanuts and wool have produced excellent textiles.

Women's coats are being made from Aralac, a "wool" that never was near a sheep. Aralac comes from casein, the protein in milk, and is made by the National Dairy Products Company (interesting name for a textile firm?). The proteins, which contain amino-acid building blocks, are being juggled around just as chemists juggle (and rearrange) the hydrocarbon building blocks in coal and petroleum. Wool is a protein. Hence, if the amino acids in casein are assembled as they are in wool, the chemist gets a synthetic wool that is warm and soft and costs about half as much as the natural product.

The use of melamine resins and other plastics may give us paper shirts and other articles that will be attractive but so cheap that we can throw them away when soiled.

\section{Postwar Predictions}

Let us now spotlight some of the developments in chemistry, and see what they will mean to you in postwar years.

Light metals, plastic bonded plywood, plastics, and other materials will revolutionize home construction and give us better homes at lower cost. Probably the most impressive advances to be achieved directly or indirectly by chemical research and engineering will be in the field of transportation. Huge luxury air liners, and cargo planes; light, low-cost family planes, and rotary-wing craft; and better automobilesall will be made possible by the advances in metallurgy, highoctane fuels, plastics, and other fields of research. The railroads will compete with other forms of transportation by using aluminum, magnesium, and light-alloy steels for passenger and freight cars which will weigh far less, move at 
much higher speeds, and cost less to operate than present equipment.

Our military planes now are using "roo octane" gasoline, and industrial chemists are working on fuels of " 150 octane" rating. The use of liquid hydrocarbons (derived from coal, petroleum, and natural gas), which are highly efficient and can be pumped long distances by pipe lines, may render obsolete the present-day industrial power plants.

In a careful survey of the chemical industry's past and future prospects the investment house of Merrill Lynch, Pierce, Fenner and Beane declares:

"If a true list of essential industries is ever compiled, the chemical industry will inevitably be near the top of the list. For industrial chemistry is not only as essential to peace as it is presently in war-it is vital to life itself. And it is literally true today that industry as a whole cannot function without the chemist. The chemical industry, then, is the base from which all other industries stem to form the complex structure that is our national economy and the American way of life. So industrial chemistry is not just essential; it is indispensable." 


\section{$\mathrm{XI}$}

\section{METALS THAT BUILD NEW WORLDS}

Most of Us are incapable of realizing the extent to which new metals will transform tomorrow's world. We are in the habit of looking to new mechanical devices and discoveries for portents of the future. It is true that in the past such inventions have revolutionized everyday living. But in tomorrow's world nearly everything we touch, see, and use will have been profoundly altered by the new light, powerful metals developed in recent months for war use. These metals will make possible the manufacture of a thousand aids, comforts, and safety devices we do not know today.

A glance at the war picture will reveal why some of them were developed.

A violent Nazi antiaircraft barrage tosses the Flying Fortress about as it completes its bombing run over the target. Suddenly a waist gunner is knocked several feet and slumps to the floor. The bomber weathers the storm of bursting shells; and a companion bends anxiously over the waist gunner, who has regained consciousness and is trying to get up. Examination shows that he merely had been stunned by a piece of flak which dented, but did not pierce, a new steel jacket he is wearing. This device is a sleeveless canvas jacket with slits into which one hundred and twenty pounds of tough steel plates are slipped. It can be removed instantly by pulling a release cord.

North American P-52 Mustangs roar across France, blazing away at Nazi ground defenses and freight trains. At least 
75 per cent of the weight of these warplanes is aluminum, light but strong metal of many uses. Two hundred pounds of lighter magnesium-silvery-white metal "mined" from the ocean-also went into the engine and other parts of these Mustangs.

A flight of Republic $\mathrm{P}_{-47}$ Thunderbolts thunders across a field, leaps into the sky, and soon climbs out of sight. The turbosuperchargers, which enable these planes to fight at great altitudes, are made of special alloys-mixtures of metalsthat can stand engine-exhaust temperatures of 1,500 degrees Fahrenheit, and cold of 67 degrees below zero.

Huge "battle wagons" prowl the seven seas guarding United Nations life lines. One of these 45,000 ton battleships requires 42,000 tons of alloy and carbon steel for the hull and machinery alone.

"This 42,00o tons," explains Admiral S. M. Robinson, "includes ordered steel weights, plus ingot weights for the heavy forgings. To this amount must be added an equal weight of ingots for ordnance. . . . Remember that the barrel of a 16 inch naval gun alone, excluding the breech mechanism and turrets, consumes from 500 to 600 tons of steel."

Just a few examples of the thousands of war jobs that metals are performing today, and a reminder of the big jobs they will perform in the future. The lightweight metals-aluminum and magnesium-new alloy steels, and combinations of littleknown metals will compete vigorously with one another and with the new plastics. Together, all of these materials will revolutionize living in the postwar world.

\section{The Story of Aluminum}

Aluminum is the most common metallic element in the earth's crust. But it is never found free in nature. It always is found in combination with other substances, and scientists 
spent many years trying to produce the metal at reasonable cost. In 1854 Sainte-Claire Deville, a Frenchman, announced that he had improved the process by which Friedrich Wöhler had obtained pure aluminum in 1827. Napoleon III aided Deville's work, because he saw a chance of using this light metal for helmets and armor. Deville cut the cost of aluminum from five hundred and forty-five dollars per pound to seventeen dollars by 1859 .

In 1886 twenty-two-year-old Charles Martin Hall, who had been graduated from Oberlin College (Ohio) a few months earlier, discovered a cheap process that would produce large amounts of the metal. (In France twenty-twoyear-old Paul L. T. Héroult also discovered this process.) Hall had been intrigued by Deville's statement that every claybank was a mine of aluminum, and by his professor's remark that anyone who produced cheap aluminum would be a benefactor to mankind and also make a fortune.

Instead of using clay in his process, Hall used pure aluminum oxide obtained from bauxite and cryolite, a mineral found only in Greenland. (We are not necessarily dependent on imports from Greenland, as cryolite can be prepared from fluorine, sodium, and aluminum.) Cryolite's job was to dissolve the alumina (aluminum oxide), as sugar is dissolved in water. Then the solution was put in an iron crucible or box lined with carbon. An electric current was passed through the solution, the oxygen burned off, and pure aluminum drained from a hole in the bottom.

Hall's process soon slashed the price of aluminum to two dollars a pound. Today it is around fifteen cents a pound. The world production of aluminum jumped from sixteen tons in 1886 to 270,000 in 1929. In another ten years United States production alone was $400,000,000$ pounds and was expected to hit 2,100,000,000 pounds in 1943. Tremendous amounts of electricity are needed to produce aluminum, but new hydro- 
electric plants in the Tennessee Valley and on the Columbia River are helping to solve this problem.

Most of the world's warplanes are made of an alloy consisting of aluminum, copper, magnesium, and manganese, and called duralumin. A new secret aluminum alloy has been developed for war use. It is said to add ro to 25 per cent to the strength of the metal.

R. L. Duffus, in the New York Times Magazine, sums up past advances and future prospects of aluminum:

"Cheap and abundant aluminum is here, cheaper and far more abundant aluminum just around the corner. One picks up a handful of bauxite from a stockpile. It wouldn't look well in the middle of the parlor rug. Apply the magic of modern chemistry and metallurgy to it and suddenly it shines; and in the glitter one can see not only the flames of war but the glow of cleaner, more beautiful homes, public buildings, motor cars, railroad equipment-in fact, a more splendid material civilization."

Much of the bauxite comes from Surinam (Dutch Guiana), although smaller amounts are obtained in Arkansas. Alunite, an ore found in Utah and other Western states, also is used in place of bauxite, while TVA engineers believe that abundant aluminum can be obtained from a clay called kaolin.

\section{The Ocean as a Treasure Chest}

The ocean is the world's greatest storehouse of minerals. A cubic mile of ocean weighs about $4,500,000,000$ tons and contains about $3 \frac{1 / 2}{2}$ per cent of dissolved salts, weighing around $155,000,000$ tons. Sodium chloride (ordinary table salt) and other sodium salts make up about i $17,000,000$ tons of this total; magnesium salts, 23,000,000 tons; calcium salts, $6,000,000$ tons; and the remainder is made up of salts of other metals. 
"In land mines," explained John J. O'Neill in the New York Herald Tribune, "the desired elements usually are locked in rocky matrices of silica and other undesired substances. It is usually necessary to grind the ore to a powder for processes in which the desired metals are separated.

"When the ocean is used as a source of minerals it is necessary to get rid of a large quantity of water. If only one of the ocean salts is desired the handling of the great quantity of water usually is a costly task. When it was sought to get bromine from the ocean for use in anti-knock gasoline the water was pumped through a series of tanks and towers on a ship and a gas bubbled through the water. The gas combined with the bromine and carried it away to be precipitated and returned to the extraction tower."

In 1934 the Dow Chemical Company began operating a plant, on the coast of North Carolina, which used a simpler process to get bromine from the ocean. Dow engineers estimated that a chunk of ocean one mile square and eighty-nine feet deep was pumped through the plant in twelve months.

John J. O'Neill points out that in some places nature has performed some of the work of extracting the excess water:

"This takes place particularly in salt lakes. The Great Salt Lake in Utah is such a body of water. The evaporation of such lakes in the past has produced now-buried deposits of all of the ocean salts. About 2,000 feet under Michigan is buried a salt lake providing a vast supply of brine in which magnesium and other salts are concentrated."

The Dow Chemical Company has plants which use brines from this Michigan salt lake to produce bromine, magnesium, and other products.

In 1940 the Dow Chemical Company constructed plants on the coast of Texas to take magnesium and bromine from the ocean. Magnesium salts are obtained from the water. These are treated with hydrochloric acid to form magnesium 
chloride. Then an electric current is used to break the compound into magnesium and chlorine. The light magnesium floats to the top and is skimmed off, and the chlorine is utilized to make more hydrochloric acid. Eight hundred tons of water are handled during the production of one ton of magnesium. Dr. H. H. Harrington, metallurgist in General Electric Research Laboratories, estimated that the $23,000,000$ tons of magnesium salts in a cubic mile of ocean could yield 4,500,000 tons of magnesium-enough to supply 90,000,000 pounds of the metal each year for one hundred years. Magnesium also is obtained from several ores found in the Western states.

\section{One Pound of Magnesium}

C. L. Mantell, in Sparks from the Electrode, ${ }^{1}$ writes:

"From a pound of magnesium we can make a bar of the metal a half inch square and 64 inches long, while such a bar from a pound of aluminum would be 42 inches long, and from steel only 14 inches long. A beam of magnesium, light enough in itself to be carried by one man, can yet support an automobile! A steel piece of similar size probably could not be lifted by four men. The advantage of magnesium in the matter of weight alone, especially in aviation and building, makes its production worth the effort."

Magnesium is not quite as strong as aluminum. But as a structural material it always is used as an alloy, usually with aluminum. These alloys are called Dowmetal, and are much stronger and harder than magnesium alone. Magnesium, which burns with an intense white light, also is used in bomb casings, incendiaries, tracer bullets, flares, and star shells.

Aside from their uses in airplanes, engineers expect mag-

${ }^{1}$ Mantell, Charles Letnam, Sparks from the Electrode. New York, The Century Company, 1933. 
nesium alloys to be utilized in postwar automobile engines, making them lighter and more efficient. These alloys also will be useful in home construction, household appliances and equipment, and scores of other applications.

Only 6,000,000 pounds of magnesium were produced in the United States in 1939 , while at the end of 1942 production was at the rate of $260,000,000$ pounds. It was stepped up during 1943 to $627,500,000$ pounds.

\section{"Tailor-Made" Steel}

We need iron in our blood, and iron and steel are the "lifeblood" of modern industry. With the exception of aluminum, iron is the most common metal in the earth's crust. It is found combined with oxygen in such ores as hematite (most important iron ore in the United States), magnetite, and limonite. Iron is obtained from the oxide by heating it with carbon and removing certain impurities. Steel is merely a kind of iron which is hardened by burning out the carbon and other impurities and then adding just the correct amount of carbon. Harder steel can be made by heating and then cooling it suddenly by "quenching" in water or oil. Softer steel can be produced by heating it and allowing it to cool slowly.

Special kinds of "tailor-made" steel can be produced by adding small amounts of other metals. These steel alloys make the armor plate for ships and tanks, and the guns and other equipment that give our armed forces their tremendous striking power.

Pinkish-gray manganese makes a tough manganese steel which is used in railroad switches, dippers of power shovels, rock crushers, and other equipment that must stand hard wear. Manganese also is vital in the production of all kinds of steel. Small amounts of this metal are added to steel to 
remove sulphur and oxygen. If the sulphur were not removed it would cause the steel to become brittle. (Manganese likewise is used to harden aluminum.)

Steel as well as iron rusts when exposed to air. So 12 to 18 per cent of chromium is added to make a "stainless steel" which resists corrosion. Chrome steel, containing smaller amounts of chromium, is very hard and elastic and is valuable for armor plate and for bearings.

Nickel steel is resistant to corrosion and tough enough for armor plate, guns, and bridges.

Tungsten steel is used by machine tools to cut and shape other metals. A tungsten-steel tool does not lose its cutting edge even when heated red-hot by long use at high speeds. Tungsten sees to it that our fighting men get enough weapons on time. The tungsten filament in Mazda lamps provides much of the world with light.

Molybdenum steel matches tungsten steel in its resistance to heat; hence it can be used for cutting tools, and for axles and other equipment where toughness is demanded.

Vanadium steel has high tensile strength and elasticity, which make it valuable in the production of axles, crankshafts, and gears.

\section{Precious Common Metals}

When war came, we were faced with the fact that the nation's industry depended largely upon imports for five of the six metals listed above. Only molybdenum, 85 per cent of which is produced in the United States, was abundant. But it also got short because great amounts were used to replace nickel, chromium, and tungsten in high-grade steels.

Seeking to solve our shortage problems, metallurgists have yanked a lot of rabbits out of hats. Metallurgical magic is producing N.E., or national emergency, steels, which pare down 
the amounts of nickel, chromium, vanadium, and other scarce metals in alloy steels. New and improved heat treating and working processes have made the N.E. steels possible, and they are proving to be equal or superior to the high-grade alloy steels for many purposes.

Copper, the first metal man learned to use, ranks next to iron as our most useful metal. It is utilized in all types of electrical equipment. Look around the room you are in and you will probably see several objects containing copper. Large amounts of copper are used in alloys such as brass (copper, zinc), bronze (copper, zinc, tin), and gun metal (copper and tin), and with nickel and iron to make Monel metal.

Huge supplies of copper are produced in Montana, Utah, and Arizona. But the production of tanks, guns, ships, and planes for global war has caused a critical shortage of this metal. Tin is another valuable metal which is on the critical list of metals that must be conserved. In 194I we imported 60 per cent of the world's supply of tin, which is so important in many alloys and as a coating to protect other metals from corrosion. And 90 per cent of our imports came from the Far East.

The emergency has shifted silver from the class of rare and precious metals to one of great utility in war industry. Silver is similar to copper in strength, but is a 1o per cent better conductor of electricity and a much better conductor of heat. Huge amounts of silver are used each week to make bearings that will stand high loads and speeds in war equipment. Some engineers say air speeds would be reduced as much as seventy-five miles per hour if silver-plated bearings were not available.

Gold has great resistance to chemicals and could be employed for many industrial purposes. Its price, of around four hundred and fifty dollars a pound, restricts its use in large quantities. Some buildings, however, use pure gold on their 
roofs. Its weather-resistant qualities make it economical in the long run.

Lead, not a rare or precious metal, is proving worth its weight in gold in alloys replacing copper for roofing and flashings. Plentiful silicon (used in silicon steel for springs and electromagnets) replaces scarce tin in bronze.

\section{Uncommon Metals}

Several other metals, hardly mentioned outside of textbooks, have been put to work by metallurgists. Tantalum was used in incandescent lamps until replaced by tungsten. Now it is used to make electronic tubes for radios and Radar equipment. Indium, a silverlike metal softer than lead, is finding wide uses as a wartime substitute for tin. Small quantities of selenium and tellurium are added to steel, copper, and copperrich alloys to make them more easily sawed and cut. Selenium and tellurium also make lead more resistant to corrosion as well as stronger and tougher.

Lithium, the lightest of the metallic elements, is used in silver solder for brazing tungsten-copper electrical contacts. The adding of small amounts of lithium improves iron and copper used for casting. Osmium, the heaviest metal known, is employed in secret war-industry processes. It has been used in peacetime to produce hard alloys for tipping gold pens. Molybdenum, already mentioned, has taken over so many jobs in the past two years that people have forgotten that it, too, was one of the metals so long "buried in textbooks."

\section{Beryllium - the Magic Metal}

Beryllium, a third lighter than aluminum and harder than steel, deserves special mention again (we have already touched upon it in the chapter on automobiles). It was identified in 
1797, but it remained a "textbook metal" for many years. Finally the German firm of Siemens Halske began examining this metal; and in the United States, Andrew J. Gahagan and J. Kent Smith went to work on it. After two years' work they discovered that copper, a soft metal, became harder than steel if 2 per cent of beryllium was added and a heat treatment employed.

Other qualities besides toughness are making berylliumcopper useful in industry. Because they won't strike sparks, beryllium-copper hammers, chisels, wrenches, bars, are used around explosives and in oil refineries and grain elevators. The alloy's resistance to rust makes it valuable for machines that must function perfectly in damp climates.

Another alloy, beryllium-nickel, is superior to berylliumcopper. The Germans have the jump on us in making this product, but our metallurgists are certain to catch up. Great hope is held for experiments seeking to combine beryllium with the light metals-aluminum and magnesium-to produce the best of all structural materials.

\section{"Powder Metallurgy"}

"Powder metallurgy" has been outstanding as a saver of materials and time in the production of metal parts for war equipment. In this process two or more powdered metals are put in a mold and then pressed into a "briquette." The "briquette" is firm but can be easily broken until it is put in a "sintering" furnace and baked. Although the temperature in the furnace is below the melting point of the metals, the powder particles are in some mysterious way fastened tightly together.

American-made tanks, guns, planes, ships, radios, trucks, and locomotives are using parts of many shapes and sizes, and ranging in weight from less than one ounce to sixty-five 
pounds, which all were pressed from powdered metals. The parts can be produced so that they are within a few thousandths of an inch of the correct dimensions. Very little cutting, grinding, or chipping is required to finish the parts. This means a great saving in scarce metals, skilled man power, and time.

Self-lubricating bearings are turned out by powder metallurgy. The bearings are pressed of materials that become spongelike when baked in the sintering oven. They soak up oil and then gradually release it when in use. When a machine stops running, the bearings absorb the oil. Self-oiling bearings can be installed on tanks, and the crews never have to worry about lubricating them.

"Twenty-eight different metals are now being produced in powdered form and used in various combinations to produce tens of thousands of different products, but experts say that this is only a beginning," wrote Robert W. Marks and Harland Manchester in Forbes magazine. "Already it gives promise of turning out everything from watch parts to locomotive wheels with new speed and economy."

Dr. C. K. Leith, head of the metals and minerals branch of the Office of Production Research and Development of the WPB, has briefly sketched the work of officials in charge of getting new supplies of metals for war. "No nation," he said, "has enough of all minerals. We are developing low grade supplies at home which have never been used before. We are devising new processes for the concentration and improvement of these low grade materials and for their conversion into usable form."

In the past two years the United States Bureau of Mines has been conducting a hunt for war metals that has rivaled the gold rush of '49. Low-grade ores of zinc, lead, nickel, tungsten, chromium, molybdenum, manganese, and other strategic metals have been uncovered by engineers. Then chemists 
stepped into the picture and provided a method of obtaining the metals from the low-grade deposits. It is called "froth flotation." A mixture of water and pulverized ore is prepared, and chemicals are added which have an affinity for the metals concerned. Operating like deep-sea divers, the chemicals go down and lift the ores out of the worthless residue with which they are associated in the earth.

Reporting in 1943 to the American Iron and Steel Institute, Major General Levin H. Campbell, Jr., chief of Army Ordnance, declared that metallurgical progress by the United States in two years has exceeded German accomplishments of the past decade and advanced beyond Japanese developments of the last thirty years. The application of these great metallurgical gains, he said, is reflected in the "superquality" American armament furnished the "world's best fiighting man, the American soldier."

There is reason to believe that these metallurgical gains will help make a better world for the American fighting man when he comes home. 


\section{XII}

\section{WOOD, PAPER, AND GLASS TRANSFORMED}

WHEN MOST OF OUR SUPPLY of metals marched off to war, wood, paper, and glass quickly took over their jobs on the home front.

Wood saves seventy-nine pounds of steel every time an icebox is made. A box now uses six instead of eighty-five pounds of steel, and the remainder of it is wood. Baby-carriage bodies, handles, wheels, and springs are made of wood. The Office of War Information explains that some kinds of wood, expected to be an important substitution and already used in many items, are now fast becoming critical because of a shortage of man power in the lumber industries. Special kinds of wood may also get scarce for other reasons. These "other reasons" give us an exciting story worth saving till later.

Discussing paper's many uses as a substitute, the OWI says:

"It is possible that the case of the alarm clock which wakes the war worker, the hanger from which he takes his clothes, the base of the buttons with which he fastens those clothes, his lunch box, the wastebasket into which he throws his sandwich wrappings and the case of the flashlight he uses in his work may all be made of paper."

The war worker may buy aspirin or tooth powder packaged in paper. The biscuits for his evening meal are made from baking powder and shortening which came in paper 
containers. After his meal he may ease himself into a porch chair which resembles rattan, but if it is a new one it may be of highly processed paper. His wife may be putting the garbage into a paper garbage pail and brushing crumbs into a paper dustpan. Later they may retire under the light but warm protection of a blanket made of quilted layers of paper. The OWI adds that this blanket, which was originated for use in case of air-raid casualties, has been adopted by some thrifty households for summer use. Its low cost means it can be discarded at the end of the season with no thought of packing in moth balls.

There are, however, more than fifteen thousand different kinds of paper and paper products in use today, and paper magicians are making it perform new feats of strength every day.

Alarm clocks, flashlight cases, and many other products replacing metal on the home front are made from waste paper that is ground up and molded by great heat and pressure. Tough fiber containers, which take the place of tin cans for packing many products, are made of paperboard. Then there is the very unpaperlike "plasticized paper" now used by airplane companies.

A new method which turns coarse paper into a strikingly waterproof material was announced in mid-1 943 by Dr. William D. Coolidge, research director of the General Electric Laboratories. The materials to be waterproofed-paper, as well as cloth and ceramic insulations for radio equipmentare put in a cabinet and exposed to chemical vapors. The treatment leaves no mark upon the materials, but it does cover them with a thin film which successfully repels water and can stand temperatures of as high as $55^{\circ}$ degrees for a short time.

Another process for "water-conditioned" (aqualized) pa- 
per does not depend upon a protective coating. The paper is treated with a secret chemical compound which binds the fibers together so that water cannot get between them and float them apart. The fibers in aqualized paper are "welded" together so firmly that a towel of this material can be soaked with water and rubbed vigorously and still remain whole. Even after being in water many minutes the aqualized paper will support twenty-six pounds. At the same time the paper absorbs water quickly; it does not shed it like a duck's back. Potato sacks, linings for vegetable crates, meat wrappings, and similar materials for industry are made of special types of aqualized paper. Draperies for the home, and sheets and pillowcases for hospitals, are being produced. This versatile paper can be waterproofed to serve for clothing, tents, and sandbags and, unlike other waterproofed papers, it will not weaken if the protective coating is cracked or broken.

A new "plasticized paper" is made by treating paper with gluelike resin and subjecting it to pressure. This produces an amber sheet of plastic paper half as heavy as aluminum and almost as tough as steel of similar thickness. British and American aircraft companies are using this material on the wings of airplanes. Paper containers now can hold oil, grease, and other liquids, and a soaking in the ocean or a fall on concrete makes no impression on them.

The list of the new uses to which paper is being put gets longer every day. Obviously, a material that is light as well as strong will find many new jobs to do in the postwar world. Dr. Harvey N. Davis, president of Stevens Institute of Technology, envisions all-paper houses and even bicycles constructed entirely of paper. We may shy away from using paper as a structural material, but this paper won't look like paper, won't act like paper, and will soon make us forget that it ever was paper. 


\section{Nazi Germany's Reliance on Wood}

This nation has, until recently, lagged behind the Nazis in getting full value from wood. They call it "Universalrohstoff" -the universal material-and have shown that it is a source of chemical raw materials which may outstrip coal, oil, and mineral resources for many uses in the future. Wood can be used to produce food, clothing, alcohol, plastics, rubber, and numerous other products.

How Hitler used wood in his plans for the conquest of the world is brilliantly told in Dr. Egon Glesinger's Nazism in the Woodpile. ${ }^{1}$ He reveals that when Hitler, in 1928, unearthed the fact that it was lack of essential raw materials which had been the fundamental reason for Germany's defeat in 1918 he became morose and sullen. Hitler realized that his dream of world conquest would get nowhere so long as Britain and America kept exclusive control of the raw materials needed by Germany.

"It was then," writes Dr. Glesinger, "that Hermann Goering came forward with a new idea: 'Obviously the easiest way to break the Anglo-American grip is to discover and develop another basic raw material and to secure world-wide control in that field. After long deliberation my advisers and I have reached the conclusion that wood could become the raw material for world domination." "

An unknown student of forestry, Johann Albrecht von Monroy, was then introduced to Hitler and proceeded to argue that the forests could be made to yield all the essentials which Germany needed. Later Goering pointed out the two reasons why wood should be chosen to become the "raw material for Hitler's Thousand-Year Reich":

I. Wood is one of the five leading commodities in world

${ }^{2}$ Glesinger, Egon, Nazism in the Woodpile. Indianapolis, Bobbs-Merrill Company, 1942. 
trade, and ranks second only to milk in production value as a raw material and foodstuff.

2. One-third of Germany's soil is forested, as is the soil of Germany's neighbors, especially Russia, while England must import her wood.

The Monroy-Goering proposals were carried out, and Dr. Glesinger writes that "it is Hitler's belief in wood which gives him the confidence that he and his system will survive the war; that no Allied blockade can wear down the Reich."

Professor Bergius, leading Nazi scientist, who won the Nobel Prize for discovering the hydrogenation of coal (to produce gasoline), made this important comment on the value of wood as a raw material and foodstuff, according to Dr. Glesinger:

"How many people know that an acre of good forest land will produce more sugar than an acre of sugar beets? Who in America is aware of the fact that an acre of their Georgia land will yield five times as much cellulose if planted with yellow pine as it will if planted with cotton?

"Prepared with true German thoroughness, the wood utilization plans are founded," wrote Dr. Glesinger, "on a completely new classification of the uses of wood as a raw material. The five main categories are:

"a. Solid and liquid fuels [wood gas for civilian vehicles, and alcohol for the production of gasoline and synthetic rubber for war equipment].

"b. Food and fodder [sugar, proteins, and cattle feed].

"c. Cellulose and textile fibers [artificial wool and rayon].

"d. Structural material in various fields of technical application [transportable wooden huts for troops, wallboard and fiberboard, and 'wooden iron'-a type of plastic-bonded plywood for airplane parts].

"e. Wood by-products as basic materials for chemical industries." [Among them is lignin, a gluelike substance that 
binds cellulose fibers together and is expected to become more important than coal tar as a chemical raw material.]

\section{American Advances in Wood Chemistry}

American wood chemists started late in this race to utilize wood as a basic raw material and foodstuff. But already they have topped the Nazis in certain fields. A process developed by Dr. Donald F. Othmer and his associates at Brooklyn (New York) Polytechnic Institute can produce raw sugar from sawdust in minutes, while the Nazi process takes several hours. Industrial alcohol, protein yeast, glycerin, and other valuable products can be produced from the raw sugar. The next step will be the production of synthetic fibers, lubricating oil, plastics, vanillin for synthetic vanilla flavoring, etc.

Our plastic-bonded plywood and other structural materials from wood are as good, if not better, than the Nazis" "wooden iron." These materials are expected to compete strongly with the light metals and stainless steel in the construction of automobiles, airplanes, and prefabricated homes in the postwar period.

\section{Warm Clothes from the Bark of Trees}

Chemists now are busy trying to get full value from the bark of trees. Roofing felts and boards can be made of it, and the United States Department of Agriculture's Regional Research Laboratories have found what they believe is an excellent source of tanning material in the bark of the Western hemlock tree. This work is important because we have imported about half of the material needed in tanning leather produced in this country, and supplies have been cut sharply by the war. The bark of the giant redwood also has been used to make a fabric for women's hats and suits, mattresses, 
and heavy coats. The bark is shredded and mixed with reclaimed or pure wool.

The "Teco" ring, whose name comes from the Timber Engineering Company, is favored to bring a revival of timber as a structural material. A bolt alone will not serve to hold two heavy timbers together. This is where the Teco ring comes in. This metal ring is sunk into both pieces of timber and a bolt then is put through the center. The ring distributes the stresses in the connection over a wider area, and all the bolt has to do is hold the timbers together. Companies using the Teco ring have set several records on construction jobs for the Army and Navy.

The use of the Teco ring greatly strengthens wood joints and permits wood to be utilized in building huge warehouses, bridges, and airplane hangars that otherwise would require steel. Teco is expected to help wood recapture some of the construction market it has lost to steel.

\section{Nerw Treatments for Nerw Tensile Strengtbs}

Plywood, narrow strips of veneer glued together with synthetic resins which are waterproof and fungusproof, and heatand cold-resistant, will play an important part in postwar homes. These "wood-and-glue sandwiches" are stronger than solid steel per unit of weight. The Gunnison Housing Corporation uses a plywood and plastic panel that will take about any kind of punishment that nature or man can deal out. Flood waters, blows from metal objects, and boiling water make no impression on these panels.

Plastic-bonded plywood and impregnated and compregnated woods are water-, fire-, oil-, and weather-resistant. They are stronger pound for pound than aluminum or steel. Wood and wood plastics are used for United States gliders, training planes, and cargo transports. Britain's famed Mosquito bomber 
is largely of wood. (Here are the other reasons "why certain woods may get scarce.")

Germany's continued progress in wood chemistry was made possible by conservation and reforestation programs which gave her renewable sources of supply, and our forestproducts industries also are working to insure a steady supply of wood in the United States.

\section{Forest Conservation}

"By scientific cutting," wrote Robert M. Hallett in the Christian Science Monitor, "it is possible to increase the annual new growth to a point where the yearly increment approximately balances the normal amount of timber used. Industry spokesmen stress that timber is a crop-like corn or wheat-and can be harvested and renewed. Actually trees need to be cut to insure a future abundant supply of this natural resource, because trees grow old and rot if they are not harvested to make way for a new crop. Wood researchers hold that continuation of their work promises increasing dividends in productive land use, waste utilization and employment.

"The world has not grown out of the 'wood age'; it is only now entering it," concludes Hallett.

\section{Glass Miracles}

The third member of this wonder-working trio is glass. Dr. W. C. Taylor, chief of glass technology of the Corning Glass Works, Corning, New York, states in the American Glass Review that "the world would be left in chaos if glass were removed-transportation and communication would be stopped, hospitals and laboratories would be at a loss, and there would be a real blackout." 
Dr. Taylor reminded us that "the seeds of glass technology were sown roo years ago, but were not developed until the turn of the century. In its first use glass was an ornament," he added. "Later it took on more utilitarian characteristics and was made into window panes and bottles and applied to optical use."

We can see through a clear pane of glass, but we cannot see it clearly enough to describe it accurately. We cannot see its molecular structure even with the best microscope or $\mathrm{X}$ ray. But we have, according to Dr. Taylor, been able to lay the foundation of modern glass by working out the relation of the physical properties of glass to its chemical composition. Eighty of the ninety-two elements, he added, can be used in the manufacture of glass, making possible a tremendous number of combinations. Glass research to date, he said, only has scratched the surface of these.

\section{Nerw Techniques in Glassmaking}

In making glass the basic ingredients-silica (or sand), limestone, and soda ash-are carefully weighed out. Two other substances generally are included in the mixture. They are sodium sulphate, which refines the glass, and cullet (scrap glass left over from a previous batch, which aids the melting).

The ingredients are put in huge clay pots and "baked" in a high-temperature furnace. Then the molten glass is taken to rollers, which flatten it out. When the glass is the proper thickness it is moved along rollers through a tunnel-the annealing room-where it is slowly cooled. The rough glass then comes out and is ready for grinding and polishing operations, washing and drying, and final inspection before it is shipped.

Just as in the making of special alloy steels, glass manufacturers can produce many types of glass by varying the num- 
ber and quantity of materials that go into each mixture, or batch. Different chemicals and minerals are added to give the glass certain properties. And these "alloy glasses" are as superior to ordinary glass as alloy steels are to ordinary cast iron.

Since Corning brought out its Pyrex glass in 1915, tremendous strides have been made in the manufacture of flameproof glass. Ordinary glass has a high "coefficient of expansion"-that is, it varies sharply with changes in temperature -and it is a poor conductor of heat. Thus a thick piece of ordinary glass will crack when heated, because the outside expands more than the inside. The low "coefficient of expansion" of Pyrex prevents it from cracking when exposed to a flame.

Corning's latest Pyrex-type glass is said to be "so new that industry hasn't yet caught up with it." The discovery of this glass-called Vycor-has been rated one of the outstanding scientific achievements of the century. Vycor glass is 96 per cent silica-thereby approaching the characteristics of quartz, which is pure silicon dioxide with a very low coefficient of expansion and with high resistance to chemicals. Vycor is made by giving the glass a chemical treatment which removes one-third of the mass. Little but silica remains and it is in a porous state. This is reheated and the glass "shrinks" until all the minute holes are closed and a transparent, nonporous glass is produced. According to Dr. W. W. Shaver, head of the production-development department of Corning, this 96 per cent silica glass has the property of used sand. To answer any questions about Vycor's toughness, Dr. Shaver heated a cup of this glass red-hot and then plunged it against a cake of ice. The glass was not damaged.

Another glass which is similar to Vycor has been made by the Pittsburgh Plate Glass Company and other glass manufacturers. A quick-cooling process balances the forces of expansion and contraction in the glass, making it more than four 
times as strong as ordinary plate glass. A pane of this glass, resting on a cake of ice, will withstand a stream of molten lead. A two-pound ball can drop six feet on this glass and not even scratch it. This glass, and Vycor, will have many postwar uses for windows in oven doors, tops of frozen-food cabinets, strong tabletops, locomotive headlights, and revolving doors. And it is quite possible that your postwar home will have entire walls of this transparent insulating glass that keeps heat in during winter and excludes it in summer.

There are several types of glass that you won't be able to recognize as such. First we have "Foamglas," which was developed by Corning and Pittsburgh Plate Glass. This material, which insists on being called glass, can be sawed and drilled and will float like cork. The glass is made by adding pure carbon to the batch. When it is heated the carbon combines to form a gas, which puffs up the molten glass into a mass of bubbles. This foamy glass is annealed to prevent later cracking, and then is cut into slabs. A cubic foot of Foamglas has more than five million bubbles, or air cells, and weighs only ten to eleven pounds, while ordinary glass weighs one hundred and fifty to one hundred and seventy-five pounds per cubic foot.

The air cells in Foamglas make it almost as buoyant as cork or balsa wood and it is well suited for lifesavers, life rafts, and pontoon-bridge floats. At the same time Foamglas is strong enough to build walls or ceilings without special support. It won't rot or burn and is verminproof. Any termite foolish enough to tackle Foamglas will get a broken jaw for its trouble.

Foamglas is good news for the food and storage industries. It will insulate cold-storage plants, ice-cream factories and dairies, and also can be used in ovens and furnaces.

Next in line comes Fiberglas, which is used for insulation and to make attractive, flameproof draperies. In addition, 
Owens-Corning-Fiberglas has developed a glass thread for surgical sutures. This suture is stronger than silk and avoids the danger of infections sometimes caused by catgut and by silk. Then, too, there is a fibrous glass tape used to strain foreign matter from blood plasma.

Optical glass has given us "eyes" to see stars billions of miles away, and the minute germs and other organisms all about us. The full story of the manufacture of optical glass for military purposes cannot be told now. Bausch \& Lomb and the other optical manufacturers have blasted the myth of German superiority in precision optical instruments. The efficiency of American range finders, detection devices, and aerial cameras has been greatly increased. Furthermore, instruments that once were produced by hand now are turned out by mass-production methods to tolerances as fine as a ten-thousandth of an inch.

Many newcomers have been producing optical instruments for the Army and Navy. Among them are Westinghouse, Mergenthaler Linotype, Nash-Kelvinator, and MinneapolisHoneywell.

"One of the examples in American development cited by Minneapolis engineers," said the New York World-Telegram, "is the control of humidity. One bottleneck in the production of fine optical ware was the effect of humidity on glass, which on inclement days sometimes halted production completely. ...

"An engineering study was made of water and glass, and it was discovered that glass is hydroscopic, meaning it absorbed moisture and exuded it, depending on the humidity. When humidity fell the water oozed out and deposited particles of soluble salts which made the glass sticky. Rising humidity kept the water in the glass. After that the solution was simple. The company controlled the humidity to permit uninterrupted production." 
In the future, people can live in glass houses and not worry about the result of throwing stones. John D. Biggers, president of the Libbey-Owens-Ford Glass Company, declares that "houses with entire walls of transparent, insulating plate glass that keeps heat in during winter and excludes it in summer will take their place in the world of tomorrow."

Blankets of fiber glass have been used to insulate Army barracks and Navy ships. Boards composed of compressed glass fibers, and faced on one side with a glass-fiber cloth that can be painted, are used on Navy fighting ships for both heat insulation and interior finish. The board has replaced millions of pounds of aluminum formerly required and in a period of seven months saved enough aluminum to build more than two hundred four-motored bombers.

List the glass items that can replace metal ones in kitchens and you have named almost everything in the kitchen. Flameproof glass saucepans, skillets, and double boilers replace missing aluminum and scarce iron and enamel kitchenware. More and more foods are packed in glass containers rather than tin cans, saving three hundred thousand tons of steel and tin for war equipment. Glass also makes knife sharpeners, stoppers, traps for kitchen sinks, tabletops, bathroom accessories, and washboards.

Consider this incomplete list of the types of glass now performing so brilliantly on the home and war fronts:

Glass so hard it will stop a fifty-caliber bullet; glass that can be sawed, drilled, and worked with carpenter's tools; glass so light that it floats in water; glass wool so fine that a marblesized ball of glass will spin twenty miles of thread; explosionproof glass globes for use in war plants; glass that can be heated red-hot and plunged into cold water without damage; glass tubing that replaces copper, lead, and steel in plumbing; glass that can be bent and tempered to almost any shape; glass springs that don't get "tired" and are equal to steel ones; 
automobile batteries of glass; secret optical glass which, among other things, enables military observers to look directly at the sun when spotting enemy bombers.

Glass will join wood and paper in performing hundreds of jobs for us in the postwar years. The "Three Musketeers" are performing feats of strength and endurance today, and will go on to new triumphs tomorrow. 


\section{XIII}

\section{FORTUNESINAGRICULTURE}

Problems as well as crops always have been harvested by American farmers. For years they sought to expand production to feed more people. In I 800 one farmer could supply food for less than six persons. A little over one hundred years later one farmer could feed eighteen persons. Then in the 1930's the problem of surpluses plagued farmers, and production was curtailed in order to raise prices.

Today farmers and the government face the tough problem of increasing the production of many foods needed by our fighting men, civilian workers, and allies. In 1942 farm output hit an all-time high. What will happen to this tremendous productive capacity after the war? Will the problem of surpluses again plague the farmer?

Since 1935 the National Farm Chemurgic Council has spread the word that the "farm problem" can be solved in part by finding nonfood uses for crops through chemurgy"chemistry at work for the farmer." In 1939 the United States Department of Agriculture established the first of four Regional Research Laboratories at Peoria, Illinois. Other laboratories are at New Orleans, Philadelphia, and near San Francisco.

"Future historians," wrote David Dietz, Scripps-Howard science editor, "may look back to the establishment of these laboratories as the most important event of 1939. They will seek to solve the farm problem in the only way that scientists 
believe it can be solved-by finding new markets for farm products and new uses for them in industry." 1

"The very ancient art of agriculture," added Wheeler McMillen, president of the National Farm Chemurgic Council, "is today in possession of new tools of such surpassing importance as we have barely begun to suspect. Organic chemistry, one of these tools, applies terrific temperatures and tremendous pressures - and a pot of beans becomes an automobile part instead of a bowl of soup."

Dr. George Washington Carver, famed Negro scientist, who died in January, 1943, has been called the "first and greatest chemurgist." Born of slave parents, he worked his way through Iowa State College in 1896 and in that same year was offered a position by Booker $T$. Washington, founder and president of Tuskegee Institute, Macon County, Alabama. He remained at Tuskegee all his life, demonstrating how the South's "unproductive" soil could be made to produce rich crops and finding new industrial uses for farm products long before the word "chemurgy" was coined.

Like most of the South, Macon County then grew cotton and little else. Dr. Carver knew this open-row crop exposed the land to deadly water erosion and destroyed the fertile soil.

Rackham Holt, author of an excellent biography of Dr. Carver, told in the Christian Science Monitor, June 7, 1941, how he helped break the strangle hold that cotton had on the agricultural South:

"If Southern farmers were to reduce their cotton acreage they must raise other crops, and then a market for these must be found. Sweet potatoes could be cultivated easily, but they were highly perishable and yielded immense quantities of small cull potatoes which could not be used as food. George Carver abhorred waste, and from his laboratory by-products rushed

${ }^{1}$ Chapter XIV shows how a liberal diet for all American families also will do much to solve our "farm problem." 
into the vacuum. In the course of time he produced $i \mathrm{I} 8$, from shoe polish to rubber.

"Peanuts had the great advantage possessed by all podbearing plants of abstracting fertilizing nitrogen from the air, thus enriching the soil instead of depleting it. From this now famous legume (now a $\$ 200,000,000-a-y e a r$ industry, thanks to Dr. Carver) he produced a list, always out of date before it could be printed, though it numbers some 300 items-from soup to nuts gastronomically, and including soap, metal polish, plastic paper, axle grease."

Dr. Carver could have been a wealthy man, but he refused to accept money for his hundreds of inventions.

Rackham Holt wrote of how a representative of a great paint company came to see a color Dr. Carver had made from Macon County clay:

" 'Dr. Carver,' said the expert, 'according to our observations, this color is 70 times bluer than blue. We would like to put it on the market.'

" 'No, no, no!' was the alarmed response. 'I don't want to commercialize it.'

"This is the rule to which he firmly adhered. From all over America, from China, India, Japan, Russia, came emissaries or letters asking for help in problems. Often checks were included. Back would go the check, and the solution with it, whether it was how to dye cement or turn peanuts into linoleum or into milk for babies in the Belgian Congo. In all his efforts he constantly asked himself, 'How can this be adapted to the requirements of humble people?" "

Dr. Carver's pioneering work on peanuts and sweet potatoes has been followed up by other chemurgists. Progress has been made on a textile fiber from peanuts. A heat-insulating board, nearly equal to cork and much cheaper, has been made from peanut shells. Sweet potatoes are used for the manufacture of industrial alcohol, and for starch to make adhesives for stamps and envelopes. 
The bulk of our heavy imports of tapioca for adhesives, puddings, and soups came from the Netherlands Indies until the Japanese took over. Now sweet potatoes, as well as white potatoes and waxy corn, are furnishing vital supplies of starch. Waxy corn, which originated in China, was developed in the United States by the Department of Agriculture in the past two years. It is an excellent substitute for tapioca.

\section{New Uses for Skimmed Milk}

Great strides have been made recently in using billions of pounds of skim milk-the residue left after butterfat has been extracted for butter, table cream, or other purposes. The protein-rich skim milk has been used to make casein for the slick coating on magazine paper, glues, plastic buttons, buckles, and water paints. But much of the skim milk was fed to livestock for want of some better use. Now, however, casein from skim milk produces a warm, durable synthetic fiber, Aralac, used today in dress fabrics, hats, ties, scarfs, blankets. The new fiber blends well with wool, mohair, cotton, rayon. It is more expensive than rayon and cotton but less costly than wool and fur, and will help particularly to supplement our deficient supply of wool.

\section{The Soybean}

Another important source of protein needed by industry is the soybean. When these beans were imported from Manchuria years ago, self-respecting cows turned up their noses at them. Today these beans rank near the top of the list of cash crops. No other crop under the sun is quite like the soybean. It contains twice as much protein as meat, about twice the calcium of milk, and more than double the minerals of wheat. And, because of its rich oil and protein base, the soy- 
bean can be used to make a great variety of products ranging from foods and soap to varnishes, textiles, and automobile parts.

This incomplete list gives you a rough idea of what to expect of the soybean in the future:

Foods: substitutes for butter, lard, meat, coffee, and as flour, cooking and salad oil, and cereals. Clothing: substitutes for wool, cotton, leather, rubber. Cosmetics: soap, face cream, lipstick. Medicine, synthetic hormones, vitamin concentrates, medicinal oils. Home: paint, varnish, roofing, linoleum, draperies. Industry: lubricants, explosives, adhesives, automobile parts, printing ink.

\section{The Castor Bean-a Nerw Treasure}

Chemurgists have promoted the growing of many other crops with industrial uses. They believe, for example, that the castor bean may match the success of soybeans as a cash crop. Aside from its well-known medicinal use, castor oil is used in soap, paints, varnishes, inks, linoleum, artificial leather, dyes, and as a lubricant for automotive, aviation, and industrial engines. The fine, strong fiber of the plant may prove valuable for cordage and textiles and the rest of the stalk is convertible into cellulose for making plastics and many other products for the armed forces and civilians. We have imported millions of dollars' worth of castor beans from India and Brazil, and the raising of the beans in the United States has been discouraged by low prices. But when the chemurgists get through, castor bean fields may rival the cornfields of Iowa.

\section{Flax Straw for Cigarette Paper}

A lot of cigarette paper goes up in smoke each year in the United States. Three years ago our cigarette manufacturers 
were dependent upon paper made in France, Belgium, and other European countries from linen rags and old hemp sailcloth. Today hundreds of tons of cigarette paper are made each year from flax straw produced in the United States. Flaxseed also is converted into linseed oil for paints and varnishes. Flax will give the wheat-producing states another valuable cash crop.

Hemp is another fiber crop that can be used in making cigarette paper, and it is also converted into rope, twine, and heavy thread. Hempseed is useful for oil. Ramie, chia, and perilla are small plants that may someday be important farm crops. Ramie is useful for fiber, and chia and perilla furnish oily seeds. Tung oil, made from the nuts of a tree and usually imported from China, is being produced in Florida and Louisiana. This valuable oil is needed to waterproof insulation on electrical equipment. English walnuts yield an oil for food and for soaps and paints. Ground walnut shells serve as a base for insecticides, plastics, firebrick, and dynamite. New uses for pecans, almonds, and filberts are being found every day.

\section{Our Own Herbs and Drugs}

Because of the excessive amount of hand labor required, we have preferred to import herbs and drugs from foreign countries. But most of these products can be grown in the United States, and their production has been encouraged to take the place of imports cut by war conditions.

\section{Cotton By-Products}

Chemurgy also has been busy finding new uses for the older farm crops. First consider King Cotton, who has suffered several years from price-depressing surpluses. Machines have been developed to remove down or short fibers from 
cottonseed. This down is called linters and is almost pure cellulose. It is used to produce rayon, plastics for fountain pens and automobile safety glass, moving-picture film, and explosives. Cotton stalks can be used for wallboard. Cottonseed oil is converted into vegetable shortening, margarine, and salad oil.

\section{Cottonleatber}

Cottonleather, a heavy, woven cotton fabric impregnated with a plastic binder, has been developed by the Southern Friction Materials Company, near Charlotte, North Carolina. This tan-colored material is as hard, but also as flexible, as sole leather. The small plant rolled out the cottonleather at the rate of a mile in four hours. When this output did not meet the demand, the company began licensing large manufacturers to produce cottonleather. The Bigelow-Sanford Carpet Co., Inc., also announced the development of a synthetic outer sole for shoes which it said would give 50 per cent more "mileage" than leather. It is made of tightly woven cotton treated under pressure with a synthetic resin to increase resistance to abrasion, heat, and moisture. BigelowSanford believes the new product will become a permanent factor in the shoe industry.

\section{Cotton Fire Hose}

Cotton technologists in one of the four Regional Research Laboratories of the United States Department of Agriculture have found new uses for cotton cloth and yarn. Until recently all sandbags for military uses were made from jute or burlap, imported from India. Department of Agriculture research workers developed specially treated cotton fabrics that are satisfactory for sandbag purposes. These men also have 
pressed research on the production of fire hose which would not require scarce rubber or linen. Large amounts of cotton fire-hose yarn will be used, opening another market for cotton.

\section{Cotton Roads}

Tire manufacturers long have used cotton fabric in tire carcasses. More recently "cotton roads" have been built in a number of states to try out a specially woven cotton mesh used as a reinforcement for asphalt highways. "Some day, perhaps," declared the National Association of Manufacturers, "you will ride on partly cotton roads in a partly cotton automobile on partly cotton tires to a picnic where you will use cotton seed oil on a salad which you will eat with a cottonhandled fork."

\section{Corn for Photographic Films}

Much of our corn is used to feed hogs and other farm animals. Millions of bushels also are converted into corn meal, cornstarch, corn syrup, and corn sugar by manufacturing plants. But chemurgists have shown us that the cornstalks and corncobs should not be ignored. They contain valuable cellulose used in the production of fibers, photographic films, plastics, and scores of other products.

\section{Oat Hulls in the Synthetic-Rubber Field}

The Industrial Bulletin of Arthur D. Little, Inc., points out that furfural, an old chemurgic product made from oat hulls, is getting a boost from the synthetic-rubber program which may give it a much bigger place in the postwar chemical world:

"Furfural was introduced commercially in 1922 by the Quaker Oats Co., following a research program on the dispo- 
sition of the oat hulls resulting from the milling of rolled oats. It is manufactured rather simply by the reaction of dilute sulfuric acid with the oat hulls and is a mobile palecolored liquid with a pungent odor. . . . It was first used in synthetic resin manufacture to react with phenol, as does formaldehyde in forming the phenol-formaldehyde, or bakelite, type of resin. Phenol-furfural resins, which were developed before furfural became commercially available, are distinctive in some respects, including free flowing during molding; their uses include bonding of abrasive wheels and they are said to be used in cementing most U. S. electric light bulbs to their brass bases.

"The largest use of furfural, however, has been as a solvent; in 1927 it was found useful for refining wood rosin, another chemurgic development, to produce a lighter-colored, more salable product. Since 1933 a number of plants using furfural in the solvent refining of lubricating oil and diesel fuel have been built. . . . Its solvent action is responsible for furfural's place in the synthetic rubber program, where it will be used in a number of plants to purify butadiene by dissolving the butadiene and thus separating it from undesired reaction products."

Several other farm crops are being used in the syntheticrubber program. Alcohol from grains, and from high-test molasses, is converted into butadiene for the manufacture of Buna S rubber. And in June, 1943, the Ontario Paper Company plant at Thorold, Ontario, began producing alcohol for rubber from waste sulphite liquor-a by-product of the manufacture of sulphite pulp for paper.

\section{By-Products of Wood}

Mention of the Ontario plant serves to introduce the subject of wood chemistry. We are inclined to forget that a tree, like coal or oil, is a vegetable matter and can be made to produce 
as many products as the others. Wood is a combination of cellulose, long hairlike fibers; a small amount of sugar; and lignin, a resin or natural glue that holds the fibers of cellulose together. Cellulose serves as the base for plastics, rayon, paper, and many other products. Lignin is the source of vanillin in vanilla extract, which is replacing the natural product since that supply was cut off by the war. Since it is a good adhesive, lignin is used to bind laminated and plywoods for the construction of airplanes. It also serves as a tanning agent for leather and produces an excellent, low-cost plastic.

The millions of gallons of sulphite liquors which are dumped into streams and lakes by our paper mills contain valuable lignin and sugar from wood. Therefore the plant at Thorold, Ontario, which uses the waste sulphite liquor, is a great step forward. It was made possible by the work of Dr. Donald F. Othmer and his associates at the Brooklyn (New York) Polytechnic Institute and uses a process far superior to that of the Nazis, the pioneers in this work. Dr. Othmer adds that the thousands of tons of sawdust which are burned each year are a gold mine of valuable chemicals. He treated one hundred pounds of sawdust with chemicals such as lye, lime, and sulphuric acid and obtained one hundred and twelve pounds of oxalic acid (used to make celluloid, rayon, explosives, leathers, etc.), twenty pounds of acetic acid, four pounds of formic acid, and six pounds of wood alcohol. Sawdust and wood chips also have been used by William $\mathrm{H}$. Mason to make a valuable building material, Masonite.

For many years the Northern spruce supplied the pulpwood for newsprint. Then the late Dr. Charles E. Herty proved that the Southern pine, which grows rapidly on all sorts of land, could be used to make newsprint. Now the acres of Southern pine are paying farmers bigger dividends.

Dr. Henry G. Knight, chief of the Bureau of Agricultural Chemistry and Engineering of the Department of Agricul- 
ture, tells how another decidedly Southern industry-that of naval stores-has aided the war effort and will prove even more important in the future.

"In the early days," he said, "this industry's principal product-pine pitch-was considered indispensable for caulking ships. Today the raw materials are rosin and turpentine almost entirely. Their derivatives figure prominently in war materials. Thanks to turpentine and a farseeing synthetic chemical industry, we can now get synthetically the camphor we need for smokeless powder, plastics and other requirements. Our scientists discovered some time ago that American turpentine is rich in pinenes and constitutes excellent raw material for synthetic camphor. Unlike World War I, when Japan was our ally, the supply of natural camphor is now completely shut off."

\section{No Soap Shortage Abead}

Dr. Knight continues:

"The supply of palm and coconut oils from the Pacific Islands is also shut off and fat and oils available for soap stock are steadily decreasing. We need fear no serious soap shortage, however, for we can look to rosin to supplement our soap stock. As this Bureau has shown, rosin is not a filler, but when judiciously used with soap oils it will make good soap.

"The naval stores industry is not one of the big industries of this country. Nevertheless, some four to five hundred thousand people in the pinebelt-from North Carolina to Eastern Texas-depend on it in whole or part for a living. Today the pine resin, or 'pine gum' as it is called, is still converted into but two raw materials-rosin and turpentine. But," he adds, "the natural resin complex, consisting largely of terpenes and diterpene, is, like coal tar, destined to become a source for a host of valuable chemicals-chemicals which are not only im- 
portant in the present emergency but which may play an important role in the post-war economy of the South."

Experts on wood chemistry emphasize that other natural resources, like coal, oil, and minerals, are exhaustible. But scientific reforestation and conservation measures can constantly replenish our supply of wood, and further research will open new markets to this valuable raw material.

We now look at research in other fields. Here, too, we find new products and processes that will help the farmer grow better crops on the farm of tomorrow, and also enjoy life more while he is doing it.

\section{Soil Building}

The synthesis of ammonia to supply nitrogen for explosives will result in abundant supplies of low-cost fertilizer being available in postwar years to increase crops and enrich wornout lands. When plants grow they remove nitrogen and other materials from the soil. If the plants die where they grow, most of these materials are returned to the soil. But when plants are removed from the soil these materials are lost, and they must be returned by the use of certain soil-building crops or by the application of fertilizer.

In recent years the TVA has developed an excellent program of experiments with phosphate fertilizers and in the education of farmers for better agriculture. In two hundred years erosion by wind and water has ruined or impoverished about $282,000,000$ acres in the United States. Water erosion takes more than $3,000,000,000$ tons of soil from farmlands each year. Experts in the TVA and the Department of Agriculture have shown farmers how to protect their land by terracing, strip cropping, contour plowing, check dams, and crop rotation. These methods make "running water walk off the land," thus keeping it from carrying away valuable top- 
soil. They also protect the land from wind erosion.

Government officials assure us that the all-out effort to raise "Food for Freedom" is not going to cause them to forget soilconservation programs.

"We had a good food administration in World War I, but we didn't have an agriculture program at all," they explain. "That was why the range of the great Western plains was ploughed up and planted to wheat-and finally turned to dust. We have a program now and it will not include any dust bowls caused by wind erosion on unprotected land. There is a surplus of wheat, and that land which has been restored by tree planting and the return of Buffalo grass will remain a range just as it was cut out to be."

\section{Soil-less Agriculture}

In areas where the soil cannot be saved, or where there isn't enough soil to start with, the new soil-less agriculture can take over successfully. More than a dozen years of experiments in the cultivation of vegetable crops through water feeding, or hydroponics, rather than through soil feeding, has proved the value of soil-less agriculture. The pioneer in hydroponics is Professor W. F. Gericke of the University of California. He grew vegetables in shallow tanks of water to which the chemical fertilizers had been added. The seeds were sown in a layer of sawdust or moss on wire netting just above the water into which the roots grew.

In a letter to Lancelot Hogben, Professor Gericke gave details of the yields obtained by tank culture. Four basins, each providing 25 sq. ft. of water surface, yielded 1,224 lb. of ripe tomatoes. The $28 \mathrm{lb}$. of chemicals required for this crop cost less than three cents a pound. A basin providing one-hundredth of an acre of water surface yielded 24.65 bushels of potatoes. These were grown in the open and re- 
quired $40 \mathrm{lb}$. of salts. While large yields can also be obtained with cereals, the cost of chemicals is here so large an item that the method may not justify the cost of the equipment.

\section{Farming in the Desert}

Hogben believes "we can only guess at the wider implications of this biotechnical advance." Plant growth is limited by three main factors: light energy, mineral salts, and water. Agricultural production has hitherto been confined to regions where the supply of these three essential elements is already adequate, or, as with the last two, where the local supply can be supplemented by manuring or irrigation without too much trouble or loss. The energy of sunlight goes to waste over the hot deserts where rainfall is scanty, and the sand will hold neither water nor salts. Tank culture, on the other hand, limits water loss to evaporation.

The Great American Desert, and other wastelands in the United States, may be turned into farms and factories by hydroponics. And the city dweller may be able to balance his food budget and give his family a better diet by rigging up a soil-less garden in the living room.

\section{Growth-Promoting Techniques}

Exciting experiments have been conducted with growthpromoting substances. Scientists in the Bureau of Plant Industry of the Department of Agriculture have found that tomatoes can be made to produce seedless, more solidly meaty fruits by treating the plants with the fumes of naphthoxyacetic acid. Previous methods of promoting plant growth usually involved the use of sprays or even direct application of the substances to the plants. The new method saves a lot of time and labor. 
The Russians report that butylene gas has a stimulating effect on the growth of fruit trees. They enclose the trees in a tent for two weeks before the normal or desired leafing, and pass butylene gas into the tents for a period of one or two hours. Other experiments in the United States show that potatoes will grow twice as fast and increase their yield if treated with propylene, a petroleum by-product.

One of the most powerful growth-promoting substances is colchicine, a poisonous drug extracted from the roots of the ordinary autumn crocus. It acts on the chromosomes of seeds to create new varieties of giant plants. Soon you will be able to have blackberries, strawberries, tomatoes, radishes, and other fruits and vegetables two or three times the size of any present species. Giant garden flowers also will be available. Tobacco, cotton, sugar cane, and many other plants which furnish the farmer most of his income will be larger, of better quality, and more resistant to disease.

Meteorologists are busy today telling Allied bombers when the weather will be right to go out and dump a load of bombs on German war plants. Important gains have been made in the long-term prediction of weather. All this knowledge will be on hand in the future to tell the farmer when to plant crops and when to expect trouble. Scientists are determined to "do something" about the weather, and this adds up to good news for the farmer.

\section{Making the Farm More Livable}

We have talked a lot about how abundant supplies of lowcost light metals, alloy steels, and plastics will revolutionize the construction of homes, airplanes, automobiles, and other postwar products. These materials will make better agricultural machinery, which can be sold at low prices and will be easier to keep in repair. This will mean that the farmer can 
raise and harvest his crops with fewer man-hours of labor, and therefore at less production cost. We have already voted the jeep "the vehicle most likely to succeed" when it is graduated from the Army and goes to work for the farmer.

Prefabricated farm buildings and dwellings, which can be assembled and demounted in a few hours, will bring better living and working conditions within the reach of many more farmers, as will the advance in radio, television, "walkietalkie" phones, and other electronic devices.

The revolution in transportation will also aid the farmer. No longer will his market for perishable products be restricted by distance from urban areas. Air-transport lines, using light cargo planes and helicopters for feeder-line service to isolated sections, will pick up his products and deliver factory-made goods to his door. Then, too, the dehydration and quick freezing of farm products, plus speedy air delivery to faraway lands, will broaden the farmer's market and help banish the fear of price-depressing surpluses. The paradox of surplus crops and starving people will be banished by lowercost production and lower-cost, speedy transportation of farm products.

All the above factors should add up to a shift of more people from crowded cities to "family-size farms" near urban areas. Two Harvard architects, Dr. Walter Gropius and Dr. Martin Wagner, envision a postwar America in which urban congestion would be relieved by new townships of five thousand persons, ranged along a network of superhighways. They contend that these tiny, factory-residential towns, surrounded by individual farm belts, would help empty the city slums and inaugurate a new era for millions of industrial workers and farmers.

The National Association of Manufacturers comments that "the rise of small factories in rural communities has helped in some areas to provide work for farm labor needed only at 
certain seasons. Such factories produce parts of products assembled by larger factories, or partly manufactured materials to be completed elsewhere. In other fields of manufacturing it has been found also that small plants in rural areas have advantages. If manufacturing continues to spread in this way, this movement too will aid in solving present farm problems."

In its report on postwar planning the National Resources Planning Board noted that the war program had accelerated the spread of plants to small cities and towns throughout the country. It urged that plants in certain communities be operated after the war to prevent the dislocation of farming and business life in those communities.

As we see it, the farmer can look forward to a postwar world in which advances in chemurgy and many other fields will bring him a higher income and better living and working conditions. 


\section{XIV}

\section{FOODFOR BUOYANTHEALTH}

The Miracles AHEAD in food in our world of tomorrow will not be miracles of strange new concoctions. They will be miracles of enough food and enough of the right foods, for all the peoples of the world. This miracle, when it is accomplished, will be a threefold accomplishment of education, production, and science.

Even America, with our much-boasted high standard of living, has never been a well-fed nation. In 1929, our richest year, three-fourths of our people spent five hundred dollars or less per family for food. Three-fourths of our people lived on a diet that was principally oleomargarine, flour, canned milk, potatoes, and dried beans. Only one-fourth of our people in that, our richest, year were able to afford adequate or liberal diets, including the more expensive foods like fresh butter, eggs, vegetables, fruits and lean meats.

Steibling and Ward, of the United States Bureau of Home Economics, contend that America has never produced enough food to give all its people a liberal diet, rich in meat, dairy products, and fresh vegetables. If the other three-fourths of our people are to have those foods, it would be necessary for our farmers, according to these economists, to produce 70 per cent more cows, 35 per cent more beef cattle, 35 per cent more pigs, 35 per cent more poultry, 50 per cent more sheep, 100 per cent more vegetables, and roo per cent more fruits.

Why, then, have we had periods of apparent surplus? Two reasons can cause crops to rot in one state while people live on a mere subsistence diet in another state: first, the people may 
not have enough money to spend for a liberal diet even if the food were available in the markets; second, dislocations and inadequacies in transportation, farm labor, and factory help can be severe enough to cause failure to care for the crops.

\section{Urgent Need of Food Education}

As a nation we are probably better fed now than before the war. For we are being educated.

We are being educated to think in terms of conserving our food supply. The Food Distribution Administration has given us some appalling figures on the waste of our food supply. According to them, the food wasted in American homes in 1942 was sufficient to feed the entire population and the armed forces, too, for eight weeks.

The armed forces and Lend-Lease took 13 per cent of our total food supply. American homes wasted 15 per cent of the total food supply. The total wastage of food, from the farm to the garbage pail, was 40 per cent. In other words, we wasted three times as much food as it took to feed our Army and to provide all the food sent abroad in Lend-Lease.

We are being educated to stop this waste. And we are being educated to think in terms of buying health when we buy food. Until the present emergency made the health of the nation a matter of acute concern, our interest in a really sufficient diet was moderate, to say the least. When enriched bread was first put on the market, many storekeepers introduced it and then stopped handling it. There was not enough consumer demand for the added value to enable the storekeeper to stock it. People went right on buying the same wrapper they had bought before, and the enriched bread lay on the shelf. Education is changing that situation.

However, education still has a long way to go in changing the habits of the American public. It has long been a favorite 
boast of many people that they don't "eat to live"; they "live to eat." But too often the man who "lives to eat" does not eat to live at the peak of his health.

Dr. Victor G. Heiser, former staff member of the Rockefeller Institute for Medical Research, agrees with other scientists that physical degeneration is the price modern man has paid for his present type of "progress." According to Dr. Heiser, recent experiments with rats fed the diets of two sections of India illustrate vividly that "man is what he eats." One group of rats, fed the diet of the strong, hardy people of northern India, reached an age equivalent to fifty years of human life without disease. A second group of rats, fed the diet of the stunted and disease-ridden people of southern India, were subject to thirty-nine diseases.

\section{Uninformed Buying}

Modern practices have processed the life-giving and healthgiving vitamins and minerals out of our foods. Now it behooves the scientists to restore these vitamins and minerals to our foods, and the educators to teach us to demand these elements in what we buy.

Henry Borsook and William Huse, in their Public Affairs pamphlet Vitamins for Health, give this striking example of how "uneducated buying" can contribute to the vitamin deficiency of the nation:

"Recently a Pasadena child brought the following sixteen items to school in his lunch box during a week: bread, butter, potato chips, chicken, bacon, mayonnaise, apple, banana, fruit salad, cooked peaches, strawberries, raisins, jelly, tomato, lettuce, and cake. The child's diet was deficient in calcium and phosphate. It was adequate, without being abundant, in vitamin $A$ and $B_{1}$.

"Another child brought only six items in the course of the 
week: milk, bread, butter, mixed fruit salad, peanut butter, and carrots. These lunches were adequate in every respect."

\section{Wasted Minerals}

Not only are we being educated to make our dollars and points go further at the market, but housewives are being taught not to destroy the value they get at the market by wrong handling of food. We would laugh at a savage who, meeting an egg for the first time, threw away the inside of the egg and ate the shell. But far too many cooks have overcooked vegetables, thrown the minerals and the annihilated vitamins down the drain, and fed their family the husks "daintily arranged for taste appeal."

Miss Nichols, of the Food Distribution Administration, says that one of the most serious forms of waste is "hidden waste" of the vitamin content of food through improper handlingsuch as squeezing orange juice the night before, and preparing a vegetable salad several hours before eating, and cooking vegetables in too much water.

An article in the magazine $Y o u$, for fall, r94r, sums up the vital necessity of the mineral content of the body thus:

"You are very watery. Your brains are 79 per cent water, your body as a whole is 70 per cent water. It is the other 30 per cent of ingredients that makes all the difference between a puddle and a person. That vital 30 per cent is composed of proteins, fats, minerals, and carbohydrates, in that order.

"Some seven pounds of you consists of a variety of metals ranging from salt to aluminum. Nobody has yet figured out what the aluminum is for, but at least i I of the other minerals are as necessary to you as the steel girders are to a sky scraper.

"All the iron in your body. would make only five carpet tacks, but without it you would promptly smother to death, 
for the oxygen you breathe could not be taken up by the body cells.

"We often waste the most mineral-rich parts of our food. In animal foods, the minerals are most abundant in organs, blood, bone, eggs and milk. In vegetables, they are found mainly in the brown parts of grain and sugar, the peelings of fruits and root vegetables, and the outer green leaves of lettuce-all of which are usually thrown away. And since the usable inorganic matter in food dissolves easily, much of it is thrown out in the water in which our vegetables are cooked.

"Your seven pounds of minerals might not mean much to the defense program, but they mean a lot to you in health and efficiency. It's worth your while to see that your diet contains enough mineral-providing foods, properly prepared."

Yes, we can become much more educated on the subject of food, to the advantage of both our pocketbooks and our health. We may even catch up with the five-thousand-yearold knowledge of the Chinese on the value of the soybean.

\section{Napoleon Counted on Food}

Just as the emergency is teaching the housewife to make her market basket go further with less food in it, so this war, as earlier ones, will, through force of necessity, teach our food processors many things. Philip H. Van Itallie, in his article "Dehydrated Foods" in the summer (1943) issue of Predictions of Things to Come, tells us that Napoleon "early realized that the discovery of a foolproof method of preserving food from spoilage would give him one of the most effective weapons in his widespread campaigns. He offered a prize for the best solution to this problem common to all warriors, and Nicolas Appert was thus encouraged to give the world his discovery of the art of canning."

Just as the Napoleonic Wars brought us the invention of 
canning, the first World War encouraged the development of frozen foods, and dehydrated foods are being perfected in World War II.

Napoleon's most famous military observation was that an army travels on its stomach. Even in Napoleon's time, when a good day's march was less than forty miles, the problem of food supply was as serious as the problems of ordnance and military strategy.

Today, when our mechanized Army rolls to a battle front at forty miles an hour, or flies to a battle front on the other side of the world at several hundred miles an hour, the problem of "keeping up with the stomach" taxes our production, our processing, our transportation, and our ingenuity to the full.

Just as the army of the fighting front marches to battle on its stomach, so the army of the home front must march to victory on its stomach. A nation geared to speed up must be nourished to sustain that tempo.

\section{Protein Shortages the Most Deadly}

When the end of fighting comes, the people will have a long road to march - a road back to sanity, peace, and justice. And the army of peace, as the army of war, must march on its stomach. For peace does not come when the guns are silenced. Peace does not come so long as the specter of starvation stalks the land. For when the specter of starvation stalks the world, the specters of plague and pestilence follow in its wake. Dr. Paul R. Cannon, chairman of the department of pathology of the University of Chicago, has spoken grim words of warning on the inevitable aftermath of prolonged starvation.

According to Dr. Cannon, the link which brings plague and pestilence in the wake of starvation is protein deficiency. 
Our resistance to disease germs depends on substances called "antibodies." These antibodies are made up of proteins. When our diets are short of meat, cheese, eggs, and other proteins, our bodies are short of antibodies.

"If the war goes on long enough," says Dr. Cannon, "protein shortages will be the cause of Hitler's defeat. In all lengthy sieges of the past, the combination of hunger, famine and disease has contributed to the final capitulation. It also may play the determining role in the coming siege of Hitler's European fortress.

"When people are undergoing severe malnutrition, neither slogans, propaganda, nor the fanfare of trumpets can induce them to struggle hopelessly against overwhelming odds."

According to Dr. Cannon, the food intake in calories in the occupied countries is already far below standard-35 per cent below in Belgium, and yet lower in Greece and Poland. The death rate from tuberculosis is climbing in all the occupied countries, and typhus is prevalent in Poland.

\section{Debydrated Foods to the Fore}

The problem of augmenting the food supply of Europe is a big problem now, and it will be a far bigger problem after the war. It will tax production, and tax transportation even more severely. Two of the most effective developments in waging the fight for Victory today can be the most effective aids in waging the fight for peace-the cargo plane and dehydrated foods.

The two most expensive cargoes America has shipped to Europe-in terms of value given for space required-are air and water. Every time a convoy of ten ships goes out, if nine of the ships are filled with air and water, only one can carry food and the weapons of war. Yet every time ten shiploads of "standard" foods are sent to Europe, nine-tenths of the 
cargo is air and water. Therefore, it is the processors of dehydrated foods who are helping lick the submarine menace now, and who will help banish the menace of pestilence and plague tomorrow.

R. B. Tobin, formerly the dehydrated-food expert of the Beech-Nut Packing Company, has stated that one hundred cargo planes, loaded with dehydrated foods, could supply the daily food requirement of England. For example, a five-gallon container of dehydrated beets, when prepared for the table, will serve six hundred men. Also, says Mr. Tobin, dehydration has a further advantage of not destroying the vitamin content of food.

"For example," he says, "spinach loses 75 per cent of its vitamin $\mathrm{B}_{\mathrm{I}}$ when canned. But in dehydrated spinach, the vitamin $B_{I}$ is preserved almost roo per cent. Canned peas lose 73 per cent of $\mathrm{Br}_{\mathrm{r}}$ as compared to a loss of ro to 20 per cent in dehydrated peas. Studies on meat show that there was less loss of vitamin $\mathrm{B}_{1}$ and $\mathrm{B}_{2}$ in dehydrated meat than in the canned form."

Dehydration removes from 50 to 90 per cent of the bulk from food, and compression, or smashing out of the air under tremendous pressure, removes from 30 to 70 per cent of the remaining bulk. A compressed brick of potatoes the size of a pack of cigarettes, when prepared for the table, will serve four. A package the size of a shoe box will serve one hundred people.

Dehydrated foods were introduced in the first World War. They did not "take." Any resemblance to the original flavor of the food was purely coincidental. The soldiers took one look at the pasty gray mess that was called potatoes, and decided that Sherman was right. They protested loud and long. When dehydrated foods were proposed in World War II, the Army eyed the subject askance. But when the shipping shortage became acute the Army decided to try again, and the 
processors of dehydrated foods were urged to try a little harder. They did, and with happy results. Dehydrated potatoes today, when "reconstituted" and served to the soldiers, are a far cry from the sorry spuds of the first World War.

One of the most interesting packets of dehydrated food prepared for our soldiers today is the $U$ ration, a packet to provide balanced meals for a group of men out on maneuvers which take them far from the mess hall. The list of foods available in the U-ration packet give us some idea of the striking range of foods now available in dehydrated form: tomato juice, whole-wheat cereal, sliced bacon, biscuits, lemonade, coffee, bean soup, roast beef, quick-cooking rice, hard candy, meat and vegetable stew, dried prunes, apricot spread, root beer, gum drops, and canned butter.

The canned butter provided in the $U$ ration is the combination of butter and hydrogenated vegetable fat which has been developed by Kraft. The mixture will not melt at 120 degrees, nor become rancid in tropic heat.

Other foods now being successfully dehydrated are: carrots, beets, corn, potatoes, spinach, celery, asparagus, bananas, pears, cranberries, peaches, grapes, and raspberries.

For the duration most of the supply of commercially dehydrated foods will be used by the Army. But already dehydrators are on the market for home use.

The Public Service Company of Chicago has given us the data on a simple method of home dehydration without special equipment:

"The equipment needed is a wood frame with some ordinary cotton curtain netting stretched over it. This is placed on top the metal rack which is standard equipment in gas ovens.

"First, steam vegetables to be dehydrated, using a tightly covered container and suspending vegetables above rapidly 
boiling water. Second, remove skin from vegetables or fruit. Third, cut vegetables into thin slices. (This does not apply to beans or leafy vegetables.) Fourth, put the slices on the cloth tray and place in the gas oven. Bring the oven temperature to 150 degrees, leaving door open to permit air circulation. The vegetables will be completely dehydrated in four and one-half to six hours.

"Vegetables are reduced to about one-fourth to one-ninth their original size. They may be stored for future use in glass jars. When wanted, they are soaked in water-ordinarily about three hours-and then the food is cooked as desired."

Van Itallie says this of the food problem today, the bigger one of tomorrow, and the part dehydration may play in the solution:

"If the war lasts several years more, and we are among those who think it will, the quantities of food which America will be called upon to conserve by all available means will become so staggering that every housewife will have to do her bit to reduce the load on the country's food preserving facilities.

"We have only just begun to get a taste of it. No more canned pork and beans. The beans will keep indefinitely when dried, and to cook them is up to the individual housewife. When canned food rationing comes upon us, there is bound to be a trend toward an even greater consumption of fresh foods, unless transportation facilities become so congested that there is not enough truck or railroad space to accommodate the bulk of fresh foods. Should this condition arise and the present scarcity of metals continue, then we will all be eating dehydrated foods, for these are the best answer to transportation shortages. They occupy a minimum of bulk and require a minimum of steel and tin. In fact, for domestic consumption, dehydrated foods can be packed in moistureproof, cellophane-lined cardboard containers. For export, 
however, tin cans will probably continue to be preferred, since determined rats make short work of cardboard.

"There are 130 million of us in this country. Right now we are probably feeding 200 million. Before the war is over, we may be feeding three starving people abroad for every American. And after the war it will take years to undo the malnutrition and starvation now stalking this globe. As we see it, the dehydrated food industry, now coming of age, is destined to become America's next frontier of opportunity."

\section{The Mechanical Corw}

Another development is furnishing food to our fighting man today and will furnish a most vital food to the undernourished millions of the postwar world. The invention is the "mechanical cow." The "mechanical cow," which is furnishing fresh milk on far-flung battlefields and on ships long at sea, works on the same principle as the plasma bank, which furnished blood for transfusions at outposts far from blood donors and blood banks. In the preparation of blood plasma the blood is dehydrated and the flaky powder that results can be shipped anywhere and kept indefinitely. When it is wanted for use, only sterile water is needed to turn it into blood again. Milk for the "mechanical cow" is broken into fats and solids. The solids are dehydrated. The fats are preserved in accordance with recent methods for keeping butter fresh in any climate and for indefinite periods of time. The milk powder and the butter can be shipped anywhere in the world. When it is wanted for use, it is only necessary to add water and to whirl the mixture of butter, milk powder, and water in a machine-and, presto, fresh milk is ready to serve. The product is a far advance over any previous development in milk powders or dried milk. Not only has the "mechanical cow" made fresh milk available in unexpected places, but it 
has given our fighting men that favorite American dish-ice cream.

When we consider the vital part milk can play in curing the evils of malnutrition, and consider the availability of fresh milk thus made possible in any corner of the globe, we rate the "mechanical cow" along with the dehydrated and processed foods of tomorrow as true bringers of a miracle world. ${ }^{1}$

${ }^{1}$ Anheuser-Busch Inc., of St. Louis, announced on August 6, 1943, the production of synthetic beefsteak from a high protein type of yeast. In making the synthetic steak, yeast is mixed with water and molasses. This mixture is treated with ammonia, which converts the yeast to protein. During the process air is stirred into the substance and 12 hours later the "steaks" are ready. This product is being delivered to the Army and the Lend-Lease Administration, and after the war it will help put cheap, vitamin-filled food on postwar tables. It has the same amount of nutrition as steak and can be compared to beefsteak so far as value is concerned. 


\section{XV \\ MEDICINE LOOKS AHEAD}

The MEDICAL PROGRESS of the future is heralded by the amazing accomplishments of wartime medicine.

Putting it statistically, look what happened to the wounded in the early period of the war.

More than 97 per cent of Navy and Marine wounded from Pearl Harbor to March 31, 1943, have recovered, according to the Office of War Information. Of all Navy and Marine personnel wounded, only 2.6 per cent died subsequently. Fifty-three per cent were returned to duty. Still under treatment, as of March $3 \mathrm{I}$, were 43.5 per cent. Invalided from service were 0.9 per cent.

Incomplete data on our Army casualties up to December, I942, showed a fatality rate of less than 4 per cent compared with 7.7 per cent in the first World War. In the Solomons fighting, deaths from abdominal wounds were less than 5 per cent. In the first World War 8o per cent of all abdominal wounds were fatal. In the original occupation of North Africa the only deaths were those of men killed outright or so badly wounded that nothing could have saved them. Four hundred soldiers who were badly burned by flaming oil during the landings were given blood-plasma transfusions. All but six were saved.

\section{New Medical Kit}

When "Johnny Doughboy" gets his gun he also gets inoculations to make him immune to diseases which killed 
more men than bullets killed in other wars. He is fortified by vitamins $\mathrm{C}$ and $\mathrm{K}$, the former to give quicker healing power and the latter to insure swifter coagulation of the blood in case of wounds. Then he is given "weapons" to fight infection and is taught how to use them.

Each man has fastened to his belt, easily removable, a firstaid packet, a package of sulfadiazine tablets-an improved sulfa drug-and sulfanilamide powder. If the soldier is hit he tries to take the sulfadiazine tablets. A special plastic container releases them into his hand one at a time, so that the hurt man will not spill them on the ground. He also dusts sulfa powder in his wound, and uses the first-aid packet.

\section{The Hospital Corps at the Front}

Generally, however, a hospital corpsman will have reached the soldier before he has had time to use his first-aid packet. Long experience has taught the Army and Navy doctors just how many corpsmen to assign to each group of fighting men. Often a corpsman is beside a wounded soldier a minute or two after he is hit.

The corpsman carries a larger kit of supplies and administers quickly to the soldier, giving him an injection of a drug which stops pain almost instantly and increases his ability to withstand the ordeal. This drug is carried in a new-type hypodermic which is marvelously simple and speedy to operate. The needle is already sterilized for instant use. After treating the soldier the corpsman ties a tag to his belt telling what type of treatment was given, fixes a bit of gauze to a bayonet or stick to mark the place where the soldier is, and then goes forward to help some other man.

Attracted by the white cloth, the litter bearers are next on the scene. They are not ordinary privates, picked at random to aid their buddies. They are trained men who know how to 
administer first aid, how to lift a wounded man to avoid further injury, how to protect a fracture with splints. They have even amputated a leg or arm in order to save a life. Furthermore, these men work fast. In a few minutes a wounded man may be picked up and carried to a battalion hospital unit four hundred to one thousand yards back. The fallen man usually is picked up in less time than it takes an ambulance to reach a street accident in one of our large cities.

The battalion aid station is a miniature hospital on wheels which goes wherever the soldier goes. It is staffed by two physicians and assistants, and has operating instruments, anesthetics, sulfanilamide, opiates to relieve pain, hot drinks, and, most important, blood plasma to combat shock and loss of blood.

\section{Blood Plasma}

One of the greatest medical advances in the past twenty years is the use of blood plasma in transfusions. Until a few years ago a blood donor had to be matched with the person receiving the blood. If the two did not agree in type, clots were almost sure to form-with fatal results. Now, however, plasma is used. This is the amber-colored liquid that remains after the red and white cells have been whirled out, as milk and cream are separated in a dairy, or allowed to settle. The water content of the plasma then is removed, and it is reduced to a dry yellow powder. This powder can be preserved, in vacuum, indefinitely and it can be restored to its natural state simply by putting the water back through the addition of distilled water.

The use of plasma saves time, and time is all-important in treating wounded men. No longer do we have to worry about blood types, because the substances that cause clots when blood types are mixed occur in the cells and not in the plasma. 
Nor do we have to bring the soldier to the blood donor; the transfusion can go to him, and halt shock before it can get started. Officers say they have found that in bad burns it is the plasma that is lost. By immediate transfusions the liquid can be restored before death occurs. "You can see the importance of this at once when you realize that an overwhelming percentage of the injuries incurred by the men in the armored corps are burns," said Major Richard D. Mudd, head of the department of Field Medicine and Surgery, Carlisle Barracks, Pennsylvania.

The sulfa drugs, which keep down infection, and blood plasma, which fortifies a wounded man against the shock and puts new life into his veins, are perfect team mates to protect our fighting men now, and our working men and women in peacetime.

\section{Mobile X-Ray Unit}

The battalion aid station, where the wounded man may receive the first of several plasma transfusions, may be compared with the emergency room in an ordinary hospital. It provides swift, expert, lifesaving treatment and surgery. One of its mobile units, to which many a soldier owes his life, is the mobile X-ray machine. In the first World War these machines were huge, clumsy affairs, not easily moved. The present battlefield $X$ ray can go to the front with the soldier. Built so compactly that it can be fitted into three small trucks, it weighs only three hundred and ninety-nine pounds and can be assembled in thirty minutes.

The soldier does not have to wait until he reaches a base hospital before X-ray pictures can be taken of his injury. This can be done an hour or so after the wound is received, and treatment begun immediately. Besides taking $\mathrm{X}$-ray pictures, the machine also has a fluoroscopic screen-through which 
the physician can examine hidden injuries. It permits a physician to locate a bullet, shell fragments, bits of masonry, and other foreign bodies within a minute after the wounded man is placed under the machine.

The soldier usually remains at the battalion aid station a day or less and then is taken by ambulance jeep, or other conveyance, back to the collecting station, which also is mobile and can be brought up near the front lines. Here a complete record of the injury is made, with recommendations of the doctors who have examined and treated the soldier.

From the collecting stations the more seriously wounded are evacuated to field hospitals or evacuation hospitals. These are usually five to seven miles back of the battle line. But, as they are highly mobile, they can be brought up to the front. They travel on six wheels, can move rapidly over soft or rough ground, and are ready for instant use. These units have the most modern medical and surgical equipment and are staffed by expert surgeons, including specialists for all kinds of injuries. Compound fractures (in which bones are broken and flesh also is torn) are cleaned, sprinkled with sulfa drugs, and the leg or arm is then encased in plaster.

\section{The "Closed Treatment" for Fractures}

This revolutionary "closed treatment" of fractures was developed by two surgeons who did not like the old method of dressing the wound-draining it and constantly washing it with antiseptics. The method worked-but not often enough to suit them. One of these surgeons was Winnett Orr, an American. As a military surgeon with the American Army in France during the first World War, Orr had the problem o. bringing home many men with compound fractures. He decided to use plaster casts to protect them on the rough voyage home. 
In cases where the fracture wound was healing, Orr encased it in plaster. But in cases where the wound was still infected, he made a plaster cast with a sort of window which allowed him to dress the wound daily. When he got home and began to take off the casts, Orr discovered something strange. The closed casts, which should have caused trouble because they didn't permit regular dressing of the wound, appeared to have speeded the healing of the wounds. The legs and arms encased in casts with windows for daily dressing and drainage did not show much improvement.

Orr thought this all over and wrote a paper which suggested that leaving the wound undisturbed, and letting nature take its course, was more important than daily treatments. No one paid much attention to the paper, but Orr began to use his method and it worked better than any other. His patients, and curious doctors, were annoyed by the overpowering smell of the casts after a week or two. Surely the leg or arm must be rotting away under the cast. But when Orr investigated he found that the wound was healing rapidly. It was not, however, until Orr used his cast treatment successfully on stubborn osteomyelitis cases (bone infections) that a number of surgeons began to follow his methods.

Several thousand miles away, in Spain, José Trueta, chief surgeon of the General Hospital of Catalonia, was using Orr's method. When the Spanish Civil War broke out, Trueta's hospital served as a base hospital for the Spanish Republican Army and he soon was busy on fracture cases from the front lines and the bomb-shattered buildings of Barcelona. He cut away the dead and dying tissue from hundreds of shattered legs and arms, aligned the fragments of bone, cleaned the wounds, packed them with gauze, and put them in plaster casts. When the odor of the casts got too strong he took them off, cleaned the already healing wounds, and put fresh casts on. 
When the war ended, word of Trueta's remarkable success spread far and wide. Trueta, who had fled to London, gradually won the support of British surgeons, and when World War II came they lost no time in adopting the TruetaOrr method. No one worried any more about the smelly casts. Fractures make up about 60 per cent of all war injuries, and those casts have worked with a death rate of less than one per cent.

\section{The Base Hospital}

Farthest back are the great general, or base, hospitals. These are not mobile and are far removed from the battle area, sometimes several hundred miles. The general hospitals have one thousand beds or more, and are the equal of the most elaborate city hospitals. The men may remain here until they are entirely cured and returned to duty, or they may be sent to general and convalescent hospitals in the United States-huge well-equipped and well-staffed institutions maintained in various parts of the country by the Army and Navy.

"Often the trip to the home hospital is made by ambulance plane," states the OWI report on Recovery of American Wounded. "There have been cases of men wounded on some distant battlefield several thousand miles away reaching this country faster than the report of their wounding; of a cheerful ' $\mathrm{Hi}$, Mom!' over long-distance telephone informing a mother of her son's safe return.

"One soldier, with a severe abdominal wound, was brought by ambulance from Egypt in 72 hours, and is now recovering rapidly in an Army hospital. Others have been flown from the Far East, Europe, India, Africa. The fact that a man knows he can be home in a couple of days from almost any part of the world is a tremendous morale-builder."

Pointing out that in this war there are no rigid and distinct 
battle lines, the OWI says this requires that our medical-care organization be ready to change on a moment's notice. That is why our medical officers are trained to adapt themselves to all conditions, and is the reason for our mobile hospital units.

\section{Mobile Bacteriological Laboratory}

Among the other mobile equipment are a bacteriological laboratory, a miniature health department on wheels, which tests water, food, and determines the nature of any disease which may attack the troops; the traveling optical laboratory, one of the newest and most interesting of the mobile units, which can supply a soldier with new glasses in a few hours after his are broken or lost; the mobile dental unit, with an easily moved dental chair and all equipment necessary to care for the teeth of our fighting men; mobile water purifiers, which go with troops to foreign territory and purify all the water drunk by our men-regardless of any guarantee of its harmlessness.

Ambulance trains are used to transfer men from evacuation points to base hospitals abroad. The first of these trains was turned over to us by the British under Lend-Lease. These trains have six ward cars, a car for sitting-up patients, a pharmacy car and other cars for storing materials, as well as operating rooms and special compartments for psychiatric cases.

"Month after month of work, research and experiment have gone into development of our Army and Navy medical equipment," reports the OWI. "This has resulted in such inventions as folding litters and folding leg and arm splints, which may be packed in small spaces for use in battle areas; the jungle kit, carried by men on duty in the tropics, containing apparatus for counteracting snakebite, various kinds of drugs from aspirin to atabrin (for malaria), salt tablets to prevent heat 
cramps, and a liquid which, spread on the skin, keeps insects away; the arctic kit, for troops in northern countries, with materials for the prevention and cure of freezing and frost bite, and 'multi-vitamins,' to keep men strong and healthy even on limited rations."

Since this war is being fought in many parts of the world, doctors assigned to troops in these areas are skilled in keeping men fit in extreme temperatures. Physicians assigned to tank corps are expert in treating men subjected to terrific noise and heat; doctors attached to submarine squadrons study reactions to pressure; doctors specially trained in the effects of high altitudes are assigned to aircraft units. If a doctor is assigned to a ski-troop section, he must be able to handle skis himself. If he is sent to a paratroop outfit, he must know how to use a parachute. He jumps with his men and floats heavier pieces of medical equipment down by separate parachute. Wherever our men fight, they are never far from the best of medical care.

\section{The Navy's Hospital Ships}

The success of a certain hospital ship, says the OWI, is one of the Navy's proudest achievements. During an extended period beginning with the Solomon Islands offensive in August, 1942, this floating hospital cared for 4,039 patientsmen wounded by bullets, shell fragments; men terribly burned, lacerated. Among these 4,039 cases, only seven deaths occurred-a mortality rate of 0.18 per cent!

The Navy's hospital ships correspond to the mobile surgical units that serve our land forces. These ships are staffed by expert surgeons and doctors, and their equipment is the equal of that in the best city hospital. They are used not only by naval forces but by land forces. They may move in close to land so that wounded men can be transferred to them from 
field hospitals. Battleships and aircraft carriers have their own hospital units, all complete. Smaller war vessels may depend on the hospital ship.

Special boats are used by the Navy to rescue men from sinking vessels or aircraft disasters over water. When an aircraft goes down, fast rescue craft which skim along shallow creeks to the scene bring survivors ashore at speeds of fifty to sixty miles an hour.

In its report on care of the wounded, the OWI pointed out that "it does not take into account other safeguards for the well-being of service men; how we rehabilitate wounded men in our great Army and Navy hospitals in this country, how plastic surgery restores mutilated faces so perfectly that only a physician can be certain any change from the original has taken place; how paralyzed limbs are returned to full usefulness by massage, exercise, and treatment by special apparatus; how a method replaces skin destroyed by burns, how therapy brings back to normal minds which have not withstood the shock of war, brings them back so completely that often they are stronger than before their brief retreat."

\section{The Magical Sulfa Drugs}

Army and Navy doctors, and research workers in laboratories throughout the nation, are searching ceaselessly for new weapons against infection and disease. We have reason to feel that in the future the peacetime conquests of medicine will save many more lives than the war takes.

In his book Bebind the Sulfa Drugs: A Short History of Chemotherapy, Dr. Iago Galdston writes: ${ }^{1}$

"The sulfonamide compounds have proved to be the greatest achievement in therapy, with the competence to save more

${ }^{1}$ Galdston, Iago, Bebind the Sulfa Drugs. New York, D. AppletonCentury Co., Inc., 1943. 
lives than any other group of agents employed in the treatment of disease."

Dr. Paul Ehrlich, the German-Jewish genius, found that germs absorbed coal-tar dyes and became visible under the microscope. He hoped to discover a dye that would not only color the germs but kill them. In I910 Dr. Ehrlich perfected the arsenical compound salvarsan ("606") - the "magic bullet" that cures syphilis, and the first of the great modern chemical agents for the war against disease.

Two years earlier, in 1908, P. Gelmo, a young student at the University of Vienna, described the preparation of a coaltar compound, sulfanilamide, in a paper for his doctor's degree. Little more is known of this trail blazer. A year later, chemists of the I.G. Farbenindustrie, German dye trust, discovered that sulfanilamide could be united with other chemicals to make colors exceptionally fast. This dye combined strongly with the proteins in wool and silk. Some scientists ventured the opinion that sulfanilamide might have an equal affinity for the proteins of parasites causing disease, but little was done along this line for several years.

In 1935 Dr. Gerhard Domagk, a German pathologist, published the results of experiments with prontosil, a brick-red powder. Scientists in other countries soon discovered that prontosil was a combination of sulfanilamide and a red dye, and that sulfanilamide alone did the work.

"The British," writes David Dietz, Scripps-Howard science editor, "gave the task of testing the new drug to one of their most distinguished men, Dr. Leonard Colebrook of Queen Charlotte's Hospital in London. He was the leading authority on childbed fever, which sets in so frequently after childbirth and until then had proved fatal in one out of every four cases.

"In 1936 Dr. Colebrook treated 64 cases with the new drug and saved the lives of 61 mothers. Sulfanilamide had cut the 
mortality rate from 25 to less than 5 per cent. He made his report in London that summer at the International Congress of Microbiology. In the audience was Dr. Perrin Long of Johns Hopkins Hospital, who hurried home to Baltimore and began to try the drug, first on mice and then on men.

"America first became aware of sulfanilamide just before the end of 1936, when Dr. Long was called in to use the new drug on the son of the President-Franklin D. Roosevelt Jr., then a student at Harvard. Young Roosevelt had been taken to a Boston hospital with a "strep" throat. From that time on sulfanilamide and its derivatives have passed from one success to another."

Sulfanilamide-the "mother drug"-proved successful in the fighting of thirty different bacterial diseases. The list of diseases that it will combat reads like the label on a patentmedicine bottle, but, unlike the patent medicines, the sulfa drug really worked. It did, however, have toxic effects on patients-nausea, dizziness, fever. So scientists analyzed sulfanilamide and sought to produce derivatives that would kill germs and still not harm the body.

Sulfanilamide is a complex molecule of carbon, hydrogen, nitrogen, oxygen, and sulphur. By adding other molecules of carbon, hydrogen, oxygen, and sulphur, chemists obtained the various derivatives of sulfanilamide.

Sulfapyridine proved to be more effective than the "mother drug" in fighting certain types of pneumonia and gonorrhea. Its toxic effects were about equal to sulfanilamide, but since it worked faster it could be used with less danger to the patient.

Sulfathiazole has been equally effective against most diseases and is far less toxic than the other two drugs. Peritonitis, the deadly infection resulting from a burst appendix, has lost its terror because of sulfathiazole.

Sulfadiazine appears to be far less toxic than the others and much more powerful as a germ killer. It can even be used to 
clear up toxic conditions resulting from the use of the other sulfa drugs. Sulfadiazine also is proving highly successful in both military and civilian life as a treatment for burns. It can be sprayed directly on the burns, and acts swiftly to relieve the pain. The drug leaves a soft, flexible scar; speeds the growth of new skin; and has none of the harmful properties of tannic acid, a widely used treatment for burns.

Sulfaguanidine was developed specifically to fight diseases of the intestinal tract, which the other four drugs don't attack effectively. It is particularly useful in the treatment of bacillary dysentery, a disease that has ravaged armies throughout history. The drug clears up most cases within three to five days, and the soldier does not need to be hospitalized.

Since the different germs-pneumococcus, streptococcus, staphylococcus, gonococcus, and others-may produce a wide variety of diseases, chemists are constantly seeking other sulfa derivatives to combat them. ${ }^{1}$ Sulfasuxidine, or succinyl-sulfathiazole, has proved useful in clearing up infections of the gastrointestinal tract. But in May, 1943, there appeared a new sulfa drug-phthalyl-sulfathiazole - which is expected to be a more powerful weapon against intestinal infections, such as dysentery, than any of its relatives. It has two to four times the germ-checking power of sulfasuxidine. Doses by mouth at four-hour intervals have produced no toxic symptoms in dog or man.

Thousands of people are alive today because sulfa drugs defended them against disease germs that would have proved fatal a few years ago. In five years these wonder drugs have cut the death rate in pneumonia almost two-thirds and in appendicitis 35 per cent. Gas gangrene, which is caused by a

${ }^{1}$ More than one thousand other sulfa derivatives are being studied today by chemists. The latest sulfa derivative-sulfamerazine-has proved to be even less toxic than sulfadiazine, which had been considered in most cases the most powerful and the least toxic of these drugs. 
bacillus and not by poison gases, no longer is a great menace to the wounded soldier because of sulfa powder.

Meningitis, inflammation of the membranes that envelop the brain and spinal cord, was one of the plagues of the first World War. It may be caused by the meningococcus, the tubercle bacillus, the pneumococcus, the streptococcus, or the haemophilus influenzae. Meningitis due to the meningococcus can be treated with serum and sulfanilamide. Deaths probably could be cut to five per one hundred cases by a prompt use of sulfanilamide and sulfapyridine. Meningitis due to streptococcus and haemophilus influenzae is harder to combat. Sulfanilamide has pulled 65 per cent of the patients through the first, and sulfadiazine and serum have changed the roo per cent mortality of the second to a 70 per cent recovery.

Gonorrhea, which afflicts an estimated twelve million or more persons in the United States, is probably the most frequent cause of sterility in both sexes and often leads to other serious ailments. In terms of relative prevalence, gonorrhea is four to eight times as common in the armed forces as syphilis -now being treated speedily by the new arsenic drug mapharsen. Remarkable results have been achieved with sulfathiazole and other sulfa drugs in the treatment of gonorrhea. And now the Army and Navy are conducting tests which indicate that sulfathiazole prophylaxis will prevent gonorrhea. The giving of sulfathiazole to men before and after exposure reduced the incidence of the disease in a test group to a yearly level of 8 per thousand as compared with 171 per thousand in the control group.

Commenting on the test, the Journal of the American Medical Association said:

"It is our opinion that, under certain conditions and in a final form yet to be developed, prophylactic sulfathiazole administration would produce a remarkable gonorrhea decline in the Army. Certain dangers are involved in administering the drug, 
particularly on a large scale. In view of the magnitude of the venereal disease problem and its effect on man days lost, we believe the risks are justified."

Erysipelas, impetigo, scarlet fever, tonsilitis, and diseases of the ear-all are being routed by the sulfa drugs, and new marvels of healing will be performed in the future by these "magic bullets."

It appears that these drugs don't kill disease germs. Dr. Galdston explains that they seem to do their work by making it impossible for the particular bacteria to feed. The starved bacteria cannot multiply for an all-out attack on the body, so the body's armed forces-its white blood cells and immune bodies-counterattack and kill off the bacteria. But all the actions of the sulfa drugs have not been explained by scientists, and more is being learned about them every day. This knowledge will help doctors use the sulfa drugs in such a way as to avoid toxic effects on patients, and speed up the germfighting action of the drugs.

\section{Penicillin-Germ Destroyer}

Although great strides have been made in the conquest of disease by the use of sulfa drugs, a newcomer-penicillinis favored by many to win the germ-killing championship in the near future. The Journal of the A.M.A. hails it as "far superior to any of the sulfonamides" in the treating of infected wounds and burns. Penicillin is an extract from a common mold, penicillium notatum, similar to the molds that occur in cheese and bread. It was accidentally discovered in 1929 by Dr. Alexander Fleming, an English bacteriologist. The mold contaminated some culture plates while he was searching for an influenza-causing organism, and was observed to check the growth of some other organisms. Broth cultures of the mold were found to contain an antibacterial substance, later named penicillin. The first work was not fol- 
lowed up immediately, but in 1940 and 1941 a group of medical students at Oxford conducted careful experiments with the drug.

One of these men, Dr. H. W. Florey, visited the United States in 1941 and interested Drs. R. D. Coghill and A. J. Meyer of the United States Department of Agriculture in launching experiments in the culture and purification of penicillin. This work, at the Agriculture Department's laboratory in Peoria, Illinois, proved invaluable in developing production. A number of commercial drug houses-Merck \& Co., E. R. Squibb \& Sons, Charles Pfizer \& Co., and Lederle Laboratories-began manufacturing penicillin in 1943.

Penicillin is perhaps the most powerful bacteria-killing agent known to man. It can destroy disease-producing germs even when dissolved in 100,000,000 parts of water. Aside from being more powerful than the sulfa drugs, penicillin has given no toxic reactions even from the largest dosage. More important, penicillin has been found highly effective against the pus-causing bacteria (staphylococcus aureus) responsible for pimples and boils, and also against such serious infections as acute and chronic osteomyelitis, or bone infections; cellulitis, or inflammation of connective tissue; carbuncles of the lip and face; empyema of the chest-pus in the chest-and a type of pneumonia caused by this germ. On the other hand, the sulfa drugs have proved of only limited value against staphylococcus infections. In several cases penicillin quickly cleared up such infections after the sulfa drugs had failed and a fatal outcome seemed probable.

The first military tests of penicillin began in the summer of I943 at the Bushnell General Hospital, Brigham City, Utah, by order of Major General James C. Magee, Surgeon General of the Army. The Committee on Medical Research of the Office of Scientific Research and Development reported in the Journal of the A.M.A. that results of the Army tests were "so encouraging that plans are now in process for undertaking 
similar wound studies in ten general Army hospitals." The use of penicillin on venereal disease will be tested in six other military hospitals.

The production of penicillin from mold, however, is a difficult and space-consuming operation, and until the problem of large-scale production is solved the limited supply available will go almost entirely to the Army and Navy. A small amount is being used in a series of controlled tests in twenty civilian hospitals.

Production problems were discussed by Dr. A. N. Richards, chairman of the Committee on Medical Research.

"The difficulties which confront large-scale production," he said, "arise chiefly from the fact that in the metabolism of the mold only very minute amounts of penicillin are formed, and those only after days of growth.

"A yield of as much as one gram [about three-hundredths of an ounce] of the purified product from 20 liters [a liter is about a quart] of culture fluid would be regarded as exceptionally high." 1

But if chemists are able to take penicillin apart and see what it is made of they may be able to synthesize it in the laboratory. This would make available larger amounts of this valuable drug at low cost. Scientists have been working on this problem for several years, and a recent article in the British Journal of Experimental Pathology indicates that penicillin may be a complex member of the very large coal-tar group of compounds. Thus penicillin may eventually be synthesized from coal-tar compounds.

${ }^{1}$ A method that makes penicillin available to a much larger number of civilian patients was reported in Science, official organ of the American Association for the Advancement of Science, by Dr. George H. Robinson and Dr. James E. Wallace of the Allegheny General Hospital, Pittsburgh, $\mathrm{Pa}$. The new method consists of applying gauze saturated with the living green mold to the patient's infection, thus allowing the mold to manufacture its penicillin directly on the site of the infection. 
"When the structure of penicillin becomes known," declares Arthur D. Little, Inc., Chemists-Engineers, "research on its production and use will undoubtedly proceed much more rapidly and perhaps compounds will be found which are structurally similar and equally active but easier to use. It is indeed possible that a whole new class of chemotherapeutic materials similar to penicillin will be opened up and that penicillin will be overshadowed as sulfanilamide has been by some of its derivatives."

Already a second and more potent germ-killing drug has been discovered in the mold penicillium notatum. The new derivative, called penatin, was reported by Dr. Walter Kochalaty of the University of Pennsylvania. Penatin is more powerful than penicillin, but also is active against disease germs which are hardly affected by penicillin. Not one of fifty disease-causing and nondisease-causing organisms could resist penatin in dilutions of one to ten million parts and sometimes in dilutions of one to four hundred million.

\section{Gramicidin-New Microbe Killer}

In 1940 Dr. René J. Dubos announced that he had extracted from a special strain of soil bacteria a chemical substance he named gramicidin, which had proved the most powerful microbe killer until then known to man. Gramicidin was found, however, to be highly toxic to animals as well as to bacteria, and it had to take a back seat while penicillin exhibited its miraculous germ-killing powers. Meanwhile Dr. Wallace E. Herrell and Dr. Dorothy Heilman of the Mayo Clinic sought to determine how gramicidin produced its toxic effects on animals. They found that along with its powerful germicidal action it also had the power to break down red blood cells by the process known as hemolysis.

It was concluded, therefore, that the chemical could be used safely in local applications where it was not necessary to put 
it in the blood stream. Tests on animals proved this was the case, and gramicidin also has been used effectively on sinus infections, infections of the bladder, infected but not bleeding wounds, ulcers, and empyema from pneumonia. Drs. Charles H. Remmelkamp and Chester S. Keefer of the Massachusetts Memorial Hospital, Boston, reported that sinus infections were cleared up within forty-eight hours. Severe bladder infections that the sulfa drugs did not affect were cured within one week.

\section{Streptotbricin-Another Microbe Killer}

Working under the old adage that "the smallest bugs have smaller bugs which live upon and bite them," Dr. Selman A. Waksman, of Rutgers University, and Dr. H. Boyd Woodruff, of the New Jersey Agricultural Experiment Station, have found other germ-killing substances in a fungus which grows rampant in the soil. They reported that one of these substances, streptothricin, is so potent that a solution of one part in one million would kill millions of the deadly streptococcus germs. Nine or more of these germ killers have been isolated and work is proceeding on them.

The chief difficulty in using them to fight disease has been their extreme toxicity both to the germs and to animals. But streptothricin, closely related to gramicidin, is far less toxic and is said to show very promising results for possible human treatment.

\section{Quinine Substitutes}

When Japanese forces swept through the Far East they got control of 95 per cent of the world's quinine supply needed to combat deadly malaria. But American chemists were able 
to produce a good substitute, atabrin, because of work done by Japan's ally, Germany. Atabrine was developed in the 1920's by I.G. Farbenindustrie. If administered in heavy doses under medical supervision, atabrin will cure or check malaria. Another chemical agent, plasmochin, kills the gametacytes, the reproductive form of the malaria parasite. When the anopheline mosquito bites a person infected with malaria it sucks up the gametacytes, and then it spreads these deadly parasites to all whom it bites.

\section{"Health Bomb" for Mosquitoes}

This is why it is important to drain and spray swamps. If the mosquitoes are destroyed they cannot carry the gametacytes from an infected person to a new victim. Naval officers point out, however, that it is difficult for shock troops landing under fire to fight malaria and the enemy simultaneously. "You can't stop to dig ditches and put up screens while the enemy bullets are whistling over your head on the beach," they add. When troops go into action in malarial country they are protected with new types of insect repellent which will keep mosquitoes away for several hours. The Army also has developed a "health bomb" containing what is said to be the most powerful insecticide yet developed. It is made from sesame oil, freon, and pyrethrum, and is packed in six-inch metal pressure containers.

With this device, soldiers can destroy every deadly insect in barracks and dugouts in an amazingly short time. Cargo and transport planes returning to America from malariainfested areas can be rid of disease-laden insects in flight long before there is any danger of bringing these dangerous stowaways into the United States. The Army hopes these "bombs" will reduce the casualty rate of past wars, in which disease has 
carried off as many men as did bullets. One military authority said the device may save more American lives than any other single invention of the war to date.

Colonel George F. Spann predicted that the new insecticide, which was developed by a Department of Agriculture chemist, would prove equally popular with civilians after the war. "It can fumigate a house in a few minutes or annihilate the crawling, buzzing 'gremlins' that take the joy out of fishing, hunting, camping or picnicking," he declared.

\section{Waging War on Epidemic Diseases}

Finally Army doctors reported in May, 1943, that they had developed a new treatment for malaria that gave promise of "amazing" results. It was said to allow the victim to recover strength and weight rapidly, and to end the recurrent chills and fever caused by malaria. That was all they would say about the treatment at that time. It should prove to be worth its weight in gold in postwar years. Throughout the world eight hundred million people suffer from malaria every year, and three million of them die.

In his book Plague on $U s,{ }^{1}$ Geddes Smith writes that "the great urban cholera and typhoid epidemics of the Igth century were a logical consequence of practices that no wellbred housecat would countenance."

He quotes the description of one city's water supply given by a health officer:

"The appearance and quality of the public water supply were such that the poor used it for soup, the middle class dyed their clothes in it and the very rich used it for top-dressing their lawns. Those who drank it filtered it through a ladder, disinfected it with chloride of lime, then lifted out the dangerI94I.

${ }^{1}$ Smith, Geddes, Plague on Us. New York, The Commonwealth Fund, 


\section{Medicine Looks Abead}

ous germs, which survived, and killed them with a club in the backyard."

After Pasteur and Koch discovered the first disease germs, progress was made in teaching people the importance of a pure water supply. England and Germany led the way in water purification and in the early 1900's American cities finally began to follow suit. Today people fully realize the dangers of typhoid and know that a system of purifying the water and treating the sewage is vital in preventing an epidemic.

In war-torn areas where the water supply and sewage systems of cities have been destroyed, the typhoid fever menace is ever present. In all wars prior to the first World War typhoid generally proved more deadly than shot and shell. The use of typhoid vaccine checked this disease in the first World War and has proved highly effective since then. The vaccine consists of dead typhoid germs. The injection of these germs causes the formation in a person's blood of so-called antibodies, which protect the individual against the live germs.

Our fighting men are guarded against typhoid, yellow fever, and several other diseases by "shots in the arm." Sanitary methods of sewage disposal, water purifiers, and great care in the preparation of food also protect the men in our armed services against dysentery and other diseases.

\section{The Amino Acids Promote Health and Beauty}

Your hair, nails, skin, soft tissues, and many vital secretions of your body are composed mainly of protein. And these proteins are made up of smaller "building blocks" called amino acids. Twenty-three of these acids are known today. Scientists believe these acids play an important role in many ailments. Experiments with animals have proved that the lack of one amino acid, tryptophane, causes animals to get bald 
and prevents them from having offspring. Purified amino acids have recently become available for experiment and scientists believe they deserve more attention as factors in the promotion of good health and vigor.

\section{Nature's Most Powerful Vitamin}

The synthesis of biotin, nature's most powerful vitamin and one of the rarest and costliest substances, promises to open up many new fields. The synthesis is considered one of the greatest achievements in modern chemistry and was accomplished at the research laboratories of Merck \& Co., Rahway, New Jersey, by Dr. Stanton A. Harris, Dr. Donald E. Wolf, Dr. Ralph Mozingo, and Dr. Karl Folkers.

This supervitamin is a member of the family of $B$ vitamins, which include several whose trames are very well known to the general public: thiamin, riboflavin, niacin. The world's entire supply of biotin, so far extracted largely from liver, amounts to about one-tenth of an ounce. It was so costly and rare that only minute amounts were available to research workers, who paid for it at the rate of four million dollars an ounce!

In 1936 Professor Fritz Koegel and Dr. B. Toennis of Utrecht, Holland, succeeded in extracting I.I milligrams of the pure substance. They got this infinitesimal amount from five hundred and fifty pounds of dried yolks of duck eggs imported from China. It was so potent that one part in five hundred billion could still function as a growth-promoting factor for yeast. One gram dissolved in twenty-five million gallons of water would be strong enough for the life needs of bacteria.

Yeast and bacteria need this supervitamin. And so do all higher forms of life, including man. The bacteria that make the nitrogen in the air available to plants also cannot live with- 
out biotin, which means that without biotin no life could have arisen on earth.

Biotin is found in the yolk of all eggs. In order to check biotin's enormous growth-promoting powers, nature has provided a brake in the form of an antibiotin substance, named avidin, in the egg white. The synthesis of biotin now promises to shed light on the structure of avidin, its counterpart in the "balance wheel of life." When biotin is made available in large amounts it is hoped that it will provide important clues for new weapons not only against cancer but also against tuberculosis, since no bacteria have so far been found that can exist without biotin.

\section{$A$ Clue to Cancer}

Medical men have improved the methods of diagnosis and of early operation so that a good many cancer patients can be saved. But cancer remains the most terrible of all diseases. At the present rate, one of every eight individuals now living will die of cancer. No one knows what goes wrong in cells, and particularly in their growth processes, so that one or a few run wild and multiply beyond reason.

Not only has biotin been found to stimulate normal growth but, under certain conditions not yet fully known, it has been found to stimulate abnormal growth, such as the uncontrolled growth of cancer cells. This does not mean that biotin would cause cancer. It does mean, however, that if the unknown conditions causing cancer exist the presence of biotin would stimulate development of the process.

Professor Ira I. Kaplan of the New York University College of Medicine, and director of the Cancer Division of Bellevue Hospital, is carrying out tests which seek to control cancer by the administration of large daily doses of dried raw egg white. It is hoped that avidin, the antibiotin substance in 
egg white, will deprive a patient's tissues of biotin and thus check the cancer process. The results so far have been described as indicating the advisability of further tests.

\section{Research Work on the Common Cold}

The so-called common cold and the "flu" are the source of more lowered physical efficiency-and greater economic loss -than any other illnesses. During the winter of $194 \mathrm{I}$ an average of fifty million people suffered from colds, and twenty million were affected by the flu, according to a survey by the American Institute of Public Opinion. The common cold frequently paves the way for many kinds of secondary infections that are often serious. A minor epidemic of influenza occurs in the United States every other year. The last major epidemic, which swept the world in 1918 , resulted in millions of deaths.

The germs which cause colds have never been identified. They are presumed to be filterable viruses (so small they can pass through the pores of very fine filters). Not even the electron microscope has been able to spot a cold germ; although it discovered the virus of influenza-a protein smaller than some molecules. We have assumed that colds are contagious, but recent experiments indicate that this may be incorrect.

Dr. William J. Kerr and his associates at the University of California Medical School placed healthy volunteers who catch cold easily in a room where the temperature and humidity are controlled. Then they were exposed to people who were suffering from colds. These people lived together for days and drank out of the same drinking glasses. Not one of the thirty without colds caught the symptoms from those who had them. This experiment indicates that abrupt weather changes, overheating, and exposure to drafts have more to do 
with the spread of cold than a cough or a sneeze. On the other hand, if the bacteria or virus of the cold is air-borne, the use of germicidal lamps should reduce the danger of infection.

Influenza has been proved to be a virus disease, and Type A, $B$, and a probable Type $\mathrm{Y}$ have been distinguished. A virus vaccine has been administered at the University of California with fairly good results. Science believes that better vaccines will be developed in the future.

\section{Blood Plasma for Civilian Use}

Wartime advances in the use of blood plasma and the development of blood banks are proving of great aid in the treatment of patients. Big hospitals have banks of plasma and of whole blood completely tested and ready for immediate use. Of course, the small hospitals are not so well supplied. But these small institutions in New York City are being aided today by the Blood and Plasma Exchange Bank, which was established by the Medical Society of the County of New York.

"Whole blood, plasma (the pale, straw-colored liquid in which the red cells float), or dried plasma now become as negotiable as checks," explains Waldemar Kaempffert, science editor of the New York Times. "The cost of transfusions is reduced; time is saved; the poor can receive blood products free.

"The Blood and Plasma Exchange Bank is particularly competent to benefit small hospitals and tie them to the big hospitals which always have a surplus of blood. Suppose, for example, that a transfusion is called for by a physician. Members of the patient's family offer their blood. If it matches that of the patient and is acceptable there is no difficulty. But suppose it does not match, though it is good blood. 
Formerly the donors were rejected. Now two people whose blood is of no value to the patient can go to the Blood and Plasma Exchange Bank. Each gives a pint of blood. One pint of blood suitable for the patient is then sent from the Exchange to the hospital in return for the donated two pints. If only one donor gives blood to the exchange bank, $\$ 10.00$ is charged. If the patient prefers not to send donors but to pay for the blood, the cost is $\$ 20.00$, or about one-half of what was formerly charged. Thus, a large hospital with blood bank (called a supplying hospital) is interlaced with the hospitals without banks (called requisitioning hospitals). What we have is an efficient system of trading blood.

"The next step," he adds, "is to extend this plan to counties that border New York. After that a national organization is envisioned with blood and plasma exchanges all over the country. Lastly, there is the prospect that blood will be given by generous donors not only for war but for peace; for when transfusions can be carried out anywhere at low cost the demand for blood is bound to rise."

Another important development is the use of red cells obtained from blood collected at blood banks. In the past the hospitals and Red Cross stations processing the blood have thrown the red cells away. All they wanted was the plasma; therefore about half the blood was wasted. Now, however, the red cells are being used for wounds, infected burns, and ulcers which did not react to the usual treatment.

Progress also is being made in the development of a possible substitute or supplement for blood plasma in case of shortages of plasma. The substitute is obtained from either beefblood plasma or casein, the chief protein of milk. Such solutions have shown themselves as good as blood plasma for the treatment of animals suffering from shock due to repeated hemorrhage. Solutions made from pure crystals of all the essential amino acids also were beneficial. 


\section{Transplanting Vital Organs}

In the field of surgery Ralph W. Gerard, Department of Physiology, University of Chicago, looks forward to the day when it will be possible to replace entirely an injured kidney, or other organ, by transplanting into the body a healthy one. "So far," he says, "such organ transplantation has been achieved only in so simple a case as the transparent front of the eye, but there is no reason now for supposing that the successful transplantation of complex organs will not one day be possible." 1

\section{$A$ Cure for Deafness}

Drs. Valdes and Schulhof of Mexico have devised a new method of curing deafness which they believe can cure 60 per cent of all the cases in the United States and Mexico. The method consists of a plastic reconstruction of the middle and inner ear, and it has worked successfully on scores of people. The affected parts of the ear, which have been destroyed by sickness or accident, are totally removed. Plastic substitutes, made of "materials" from the patient's own body, are put in their place. These operations are performed at the Public Welfare Building, but their success has become so widespread that rich as well as poor are now flocking to the clinic of Drs. Valdes and Schulhof.

${ }^{1}$ The New York Times, November 7, 1943, reported on a motion-picture demonstration in New York City of pioneer experiments in the Soviet Institute of Experimental Biology at Moscow in which animals that had been dead as long as fifteen minutes were restored to life. The revival of dead animals is achieved by a new apparatus, known as the "autoejector." Professor J. B. S. Haldane, British scientist who made the sound-track commentary explained that the autoejector "carries out the functions of the heart and lungs." Biologists hailed the experiments as promising a new epoch in medical science, "bringing closer the day when operations now incompatible with life will be possible. These may include repair to a damaged heart or brain and the restoration of persons who died of shock and hemorrhage," the Times reported. 
Plastic materials from the chemists' laboratory are used increasingly by surgeons. In cases where injuries have destroyed the hard cartilage that lines the socket of the hip joint, the transparent plastic known as Lucite, or methyl methacrylate resin, serves perfectly. It has also been used to recondition arthritic knuckle joints and jaws. The loss of Japanese silk, needed for sutures to sew wounds, has been made up by nylon, which was introduced on a wide scale in surgery in 1943.

\section{A Treatment for Hypertension}

Delicate nerve operations, in which the surgeon partially severs a nerve, have cured several painful and deadly diseases. The neurosurgeon also can frequently clear up hypertension, in which blood vessels tighten dangerously and the blood pressure soars. Hypertension long has outranked cancer and tuberculosis as a cause of death, particularly among middle-aged persons. Heparin (from ox lungs) and dicoumarin (found in diseased clover) act to slow up the clotting of blood, thereby permitting surgeons to operate successfully on clotted blood vessels even in certain forms which formerly caused death in over 85 per cent of all cases.

\section{Regional Anestbesia}

Great progress has been made in the use of regional anesthesia in place of the "general," which puts you to sleep. One method consists of the continuous injection near the base of the spine of the pain-killing chemical metycaine, which temporarily blocks the nerve pathways for pain in the lower part of the body. It has been successfully used in operations for femoral and inguinal hernia, Caesarean delivery of a baby, set- 
ting of broken bones, amputations, and surgical treatment of varicose veins.

New instruments, such as an electronic device which gives an electric signal when it detects metal fragments buried in the tissue, and the "radio knife," an electrosurgical apparatus used in brain surgery which seals off tiny blood vessels as they are cut, permit the surgeon to work new wonders every day.

\section{Electronic Aids}

The electron microscope, which is fifty to one hundred times more powerful than the strongest optical microscope, will permit the scientist to learn more about the functions of the cells in the body, to view deadly types of virus and plan new ways to attack them. Radioactive atoms, which give off the same rays as radium, can be traced through the body. Just as the gunner uses tracer bullets to check his aim, the biochemist can use these tracer atoms to reveal the functions of the body. These new techniques and machines will, according to Professor Gerard, enable scientists to "prepare deliberately drugs and other substances which can modify cell growth, drugs which specifically hold in check or destroy disease bacteria, including perhaps the tuberculosis germ, as the sulfa drugs and gramicidin already do for many."

\section{Onion "Broadcasts"}

Shortly after the Russian Revolution a Soviet professor named Gurwich discovered that onion roots "broadcast" an absolutely new form of electromagnetic wave. Other scientists checked Dr. Gurwich's discovery and also picked up onion "broadcasts." Because the waves are produced whenever living cells are dividing and growing, they were called 
"mitogenetic rays"-or M rays. Later Gurwich "tuned in" waves coming from the human body, and other scientists proved that the rays are sent out from every tissue where the vital process of metabolism goes on.

Since different $M$ rays are produced when different changes take place in a living cell, scientists will be able to follow cell changes without disturbing the plant or animal. The blood is constantly giving out $M$ rays and recent experiments showed that these rays are affected not only by drugs but also by the age of the patient, his or her sex, state of health, hunger, sleep, or agitation. $M$ rays get weaker as a man gets tired from physical work. After he rests, the blood starts "broadcasting" again. But prolonged work, which causes serious fatigue, keeps the $M$ rays quiet several hours. Here is an absolutely accurate method of measuring fatigue.

\section{Old-Age Treatments}

Further medical advances will greatly increase life expectancy and more of us will remain healthy for a longer time. In I 850 only 2.5 per cent of the population was sixty-five and over. In 1930 about 5.5 per cent were in that category, and in 1980 about 14.5 per cent should be sixty-five or over. These figures indicate why geriatrics (the indirect treatment of the diseases of old age) and gerontology (the study of senility) will be increasingly important. In an article in $T$ he Medical World, Dr. Harry Benjamin contends that these two branches of medicine must be supplemented by a thirdgerontotherapy-the direct treatment of the aging process.

According to Dr. Benjamin the function of gerontotherapy would be to stave off old age and thus add to the years of useful life. Thus it must start early. During childhood and youth it would be preventive. After the fiftieth or sixtieth year it would use direct treatment. Prevention, he explains, 
calls for a proper mode of living, which means that faulty diet must be corrected and excesses of work and play avoided. The direct treatment of old age, he says, calls for the specific use of vitamins and hormones to aid deficient organs. The hormones are "chemical messengers" which mysteriously regulate the functioning of our bodies and minds.

\section{Air Age Problems}

"No place on earth will be more than 48 hours from your local airport" in the postwar world. This statement sums up the tremendous distance-annihilating achievement of the airplane. But it also tells public-health authorities to prepare for trouble. Because of air transport, dangerous diseases in a faraway part of the world can be carried to the United States overnight. At this moment four hundred uniformed quarantine officers and sanitary inspectors of the Public Health Service are standing guard at airports where planes from overseas come in. They see to it that planes, which already have been sprayed with a chemical lethal to mosquitoes, are sprayed again. Passengers are given medical examinations. Those with malaria are permitted to enter the country but they must go straight to hospitals and stay there until they are no longer sources of infection.

"Unbelievably rapid air transportation makes the problem of disease control of transcending importance," writes Hiram Blauvelt in the New York Herald Tribune, "and with the war's end it will be further aggravated when thousands of soldiers swarm back into the United States-ideal 'carriers' for every type of tropical disease and rare malady heretofore alien to this country.

"Immunization will go a long way towards protecting the populations of the world, whether at home or traveling, from many of the dread diseases. But the real solution will come," 
he contends, "only when the nations of the world join in an international effort to eradicate disease at its source. And the airplane, now serving as the most destructive weapon of all time, may well some day be credited with being the greatest instrument for post-war happiness. It will be that when the peoples of the world, realizing the dangers of its capabilities in spreading disease, join forces to insure freedom from pestilence for all." 


\section{XVI \\ MORE MIRACLES AHEAD}

So MUCH FOR the miracles ahead in the world which is just around the corner. What of the world which may not be just around the corner, but over the next range of mountains?

These miracles farther ahead may sound fantastic to us now. But the most youthful of us can remember when many of the actualities of today were the fantastic "what if's" of yesterday.

Dr. Charles M. A. Stine of Du Pont reminds us that "already our world of 1940, in which we took such pardonable if mistaken pride, is so distant in the past that it has become an antiquity, as seen through scientific eyes."

The impossibilities of the days immediately before Pearl Harbor have become today's realities. In this war we have done a great many things that we couldn't do. So the last two years have brought tremendous changes. And the first two years after the war may bring even more fantastic changes.

Those things may be beyond our comprehension now; they may be beyond the reach of our scientists at the moment. But Browning, in his "Andrea del Sarto," voiced the most characteristic slogan of the research scientist:

... a man's reach should exceed his grasp,

Or what's a heaven for?

The day may come when we can use the atomic energy in a lump of coal to run a factory for a week. Our electric power today is gained by tearing loose some of the more- 
amenable electrons from the atom. Of course, the more amenable the electron is about leaving the atom, the less energetic it is about going back again. Developments in cosmic rays and atom smashing were checked by the war, but scientists are learning to dissociate the less-amenable portions of the atom. When they finish this work we will have a source of energy that is without parallel today. For instance, the atoms in one pound of uranium, a very heavy metal, contain as much power as millions of pounds of coal.

\section{The Amazing Cyclotron}

The cyclotron, known as the "atom smasher," gives scientists an important tool for releasing the enormous power of the uranium atoms. A sufficiently powerful cyclotron bombardment, in which neutrons bombard the uranium atoms, would release 175,000,000 volts of energy. Scientists don't set any date when atomic energy will be ours to use for industrial purposes. It could be here in a year or two, or many years. When it does come all of our needs can be taken care of with a fraction of the labor now required.

In past ages the alchemists spent their lives trying to turn base metals into gold. Rutherford, in recent years, proved that this transmutation of matter was not beyond our power. $\mathrm{He}$ changed nitrogen to hydrogen by tearing electrons away from the atom of nitrogen by bombardment, and did the same thing with several other elements. Today our power to transform the elements has been greatly enhanced by the cyclotron. It can rearrange the atom's structure and change it into something else. A stream of electrons is used to knock loose the nuclei, or "deuterons," from atoms of hydrogen. Then these deuterons strike with terrific speed at the object that is to be bombarded. This bombardment changes the arrangement of its atoms. 
"When the bombardment takes place," wrote Bruce Bliven in the New Republic, June 16, 1941, "almost unbelievable changes are created in the substance exposed to the deuterons. Iron has some of its atoms changed into those of cobalt or manganese. Others remain iron, but with a wonderful new quality of radioactivity. That is, the iron takes on temporarily the qualities of radium itself, giving off radium's powerful and penetrating rays.

"The cyclotron-made 'synthetic radium' can, moreover, be employed in tremendously important ways not open to natural radium. For the marvelous fact is that, except for giving off rays, a radioactive element acts precisely like the same element found in nature. When radioactive calcium, for example, is fed to a patient, it accumulates in his system just where normal calcium does.

"This is of such importance to medicine that informed physicians say the cyclotron is the most wonderful medical tool since the microscope. For some chemicals naturally settle in certain parts of the body. If you were to drink a solution of iodine (don't try it with the highly poisonous variety in your medicine cabinet) the concentration in your thyroid gland would be 5,000 times greater than in your other tissues. In experiments on animals drastic changes in the thyroid gland have been effected with radioactive iodine taken by mouth without harm to the other tissues.

"This technique has amazing possibilities. There is, for instance, a disease of the blood cells which causes them to reproduce abnormally; its most serious form is usually fatal. Radioactive phosphorus has been found to concentrate in the affected portions of the body, and after receiving treatment, victims have lived for substantial periods."

Scientists also will be able to create many new metals and other substances for use by industry. Instead of using chemi- 
cal processes they will synthesize materials by designing the right kind of atom and making it in their laboratories.

The electrons that make radio broadcasting possible will help the chemist. They will serve as catalysts, speeding up chemical reactions by electronic bombardment of molecules. This new science of "chemotronics" promises to knock the "im" out of impossible and produce a lot of "chemical silk purses" out of sows' ears.

\section{Harnessing the Sun's Rays}

Lifting our eyes toward the source of power, we now give attention to man's old dream of harnessing sunlight. We have used the sun's rays to generate steam. And we have made considerable progress using the solar energy stored up in coal and oil, as well as that from the wind and falling water.

"Up to the present, however," declared James F. Hunt of Du Pont, "a mule which eats hay and corn and converts these materials into the energy necessary to draw a wagon or a plough is the best solar engine yet devised. One of these days, however, some bright fellow may hit upon a really good way to harness sunlight directly, and his fortune will be assured. That is what you might call hitching your wagon to a starin a big way!"

Several "bright fellows" are working on this problem and getting somewhere. The photovoltaic cell, which in one form is composed of iron coated with selenium and gold, produces electricity from light rays. A number of these cells will generate enough electricity to run a small electric motor.

"Perhaps the day will come," said James Stokley in Science Remakes Our World, "when sun-drenched desert areas of earth will be covered with such cells, turning light into electricity for the use of the world." 
We have long known that "heat" can be generated by putting two antagonistic personalities side by side at the dinner table. The scientist can generate electric power by putting two dissimilar metals together. Seeback demonstrated in 1821 that an electric current was produced when an iron and a copper wire were twisted together and heated. This is called a thermocouple. Iron and copper produce very small amounts of electricity, but recently scientists have found alloys whose dissimilarities turn out larger amounts of electric power. The sun's rays can be used to heat these thermocouples. Or you might use coal or oil to heat huge thermocouples and produce electricity. If this "impossible" (?) method is perfected, the roundabout way of using coal or oil to produce steam, and steam to generate electric power, will be abolished.

Two antagonistic people may cause the temperature to drop as they exchange "frigid" stares. The thermocouple can do this too. If an electric current is passed through a thermocouple, a refrigerating effect is produced.

Raymond F. Yates declared in his 2,100 Needed Inventions: ${ }^{1}$

"If an inventor could apply this effect, discovered by Peltier in 1834, he could evolve an electric refrigerator that would not have one moving part, no gas, no compressors, or electric motors. Not only that, but such a refrigerator would cost one-third of present ice boxes and operate at three times the efficiency.... There is a million dollars in it for the man who can turn the trick."

And we can rest assured that there are men who will bet they can do it.

Revolutionary advances in industry may also be brought about if scientists lick the problem of transmitting cheap electric power by radio. This would mean that manufacturing

${ }^{1}$ Yates, Raymond, 2,100 Needed Inventions. New York, Wilfred Funk, Inc., 1942. 
plants could go to out-of-the-way places where valuable raw materials were located, instead of being tethered to the source of power to run the machinery. Fantastic? Perhaps. "I don't know whether we can ever learn to do this," said Charles F. Kettering of General Motors. "But," he added, "all the power we have here on earth came that way-by radio waves from the sun."

\section{Electricity as Cheap as Water}

Scientists believe that further advances in the generation and transmission of electric power will greatly reduce its cost. The late Dr. Charles P. Steinmetz went so far as to say twenty-five years ago that electricity would someday be so cheap that it would not pay to read meters.

"Consider what it means," wrote' Waldemar Kaempffert, science editor of the New York Times, "if electricity becomes something that municipalities will furnish to manufacturers and house builders as they now furnish water. Air conditioning, a flowering new industry, has been held back because of the cost of electricity.

"When energy is reduced in price to the level that Steinmetz had in mind a city will be glassed over and maintained at a constant temperature and humidity the year round. Every country house will have its uniform indoor climate, manufactured at a cost less than that which we now pay for electric lighting. If Steinmetz's prediction is fulfilled-and he was one of the most distinguished electrical engineers of his timeeven Broadway at its brightest will seem dim. We may not be able to duplicate sunlight in intensity, but we shall come close enough to it."

Two other predictions of "things to come" fit in here. William F. Ogburn, Department of Sociology, University of Chicago, points out that better and cheaper air conditioning 
will tend to make civilization move southward. Areas rich in raw materials, which have been held back by unfavorable climate, will be developed rapidly when air conditioning takes a hand.

The other prediction concerns lighting. Today fluorescent lighting, which gives us more light with less heat and lower electricity bills, is a long step ahead of incandescent light. But Raymond F. Yates reported in 2,100 Needed Inventions on another efficient source of illumination, which has not yet been made commercially available. This light, he explained, is formed by placing two electrodes in an electrolyte of aluminum citrate. The one electrode is of either carbon or lead, while the other is of aluminum.

"If the aluminum electrode is connected to the positive terminal of a variable direct current supply, a bright glow and finally a brilliant series of sparkling spots will be developed on the surface of the electrode as the voltage is raised by means of a potentiometer," he added.

\section{Agricultural Yields Tripled}

There will be a lot of changes made on the farm of the more distant future. Cheap electricity will mean that plowing and reaping will be carried on by electric power rather than by gasoline, and the growing of crops could be speeded up tremendously by heating the soil. The bombardment of seeds with $\mathrm{X}$ rays will juggle their chromosomes around and produce many new plants. General Electric scientists already have obtained improved flower specimens by bombarding seeds and seedlings with million-volt $X$ rays.

In its Chemical Industry Survey the investment firm of Merrill Lynch, Pierce, Fenner and Beane announced:

"The farms of the future may be large green houses with roofs of plastics or new types of glass through which the 
ultra-violet rays of the sun will pour unhindered. Under carefully controlled temperatures and through the use of highly concentrated chemically created fertilizing agents, these farms of the future may deliver 12 crops per year; may produce much higher yields per crop. And the chemical industry, by reason of its ever broadening demand for farm products as raw materials may well provide a permanent and economically sound solution to the recurring problem of surplus crops that plagued the American farmer in the years before the war."

\section{Ships without Crews}

If Steinmetz's prediction of dirt-cheap electricity comes true, the railroad will receive a boost that will permit it to compete more strongly with the auto and airplane.

"Cheap electricity will transform the railway," wrote Waldemar Kaempffert. "Our individualistically operated locomotives will give way to electric locomotives that derive their energy from one of fifty or a hundred enormous central stations erected at strategic points."

The day may also come when the crew on the flagship will sail all the ships of a fleet. The late Nikola Tesla, great scientific genius, contended a few years ago that radiodynamic control would make it possible for us to send crewless ships across the ocean.

\section{Edible "Cans"}

Getting back home, consider the fact that you may someday dump the contents of a can of beans into the saucepanand then chop up the can and toss it in, too. If it were a cornflavored can we would have a tasty bowl of succotash. President Willard H. Dow of the Dow Chemical Company re- 
marks that we have synthetic sausage casings and tasty icecream cones, which we don't toss away. "Why stop there?" he asks.

Remarking that the possibilities of President Dow's plan are "gargantuan in scope," the Christian Science Monitor declared that "citizens ought to do some thinking on the problem. ...

"Perhaps you would prefer to contemplate an edible can of whipped cream flavor to go with preserved strawberries. One could then chop a can to pieces in the salad bowl and use the contents on home-made biscuits. The union of rhubarb and cream appeals as a happy possibility. And a tomato ketchup flavored container to surround canned baked beans should appeal to a wide public. The whole field needs thorough exploration."

When we don't feel like cooking even a delicious-flavored can, we will turn over and go back to sleep when the milkman delivers our milk at 6:00 A.M. No need to worry about getting breakfast. The foodman will deliver it at 8:00 A.M. Better Homes and Gardens for May, 1943, explains that the new war-food packages have started companies to thinking along the above line. Food for paratroopers is sealed under high vacuum in bags of laminated plastic and paper. The packages are hard as wooden boxes and can be thrown to the floor without denting. Food in packages similar to this will keep hot for hours, or even a day, after cooking. Thus food-utility companies could deliver a day's supply of meals, which would stay piping hot until you wanted to eat.

In the not-too-distant future the housewife will be enjoying the speed, economy, and convenience of electronic cooking. You can put a roast in the oven when you sit down to the dinner, and it will be ready to serve when you have finished your soup. Because this method generates heat from the inside at the same rate as from the outside, food can be cooked 
through with no danger of burning. Bread can be baked without a crust, and a large piece of meat can be roasted as quickly as a small one. Since the heat is concentrated in the food, roasters and pans stay comparatively cool and the danger of burns is eliminated.

This matter of food brings up the subject of teeth, and teeth bring up the point that you may not have to worry about going to a dentist in the future world of miracles. Research has established the fact that fluorine tends to prevent tooth decay. It would be possible to add the small amount required to the city's drinking-water supply.

\section{The Vortex Gun}

Are you smoking a cigarette now? Did you just blow a smoke ring? These questions serve to introduce a strange device called the vortex gun, which has aroused the interest of military men today and will amaze you by its feats in the future.

The vortex gun consists of a metal drum with a round opening on one side and a rubber diaphragm on the other. Demonstrating this device, Dr. Phillips Thomas, research engineer of the Westinghouse Electric \& Manufacturing Company, sighted it at a row of candles about ten feet away, and then tapped the back of the drum with a rubber hammer. One of the candles was snuffed out instantly. He pointed the "gun" at a gong, and tapped the drum. The gong rang.

"These seemingly miraculous feats were accomplished by an invisible ring of air, a smoke ring without smoke, shot from the aperture by the force with which Dr. Thomas struck the back of the drum," explained Popular Science, August, 1942. Designed on the basis of elaborate mathematical calculations by Westinghouse scientists, this device embodies the first practical application of the well-known principle of 
vortex (violently circling) motion. . . . A smoke ring, which is a true vortex ring, will move in any direction according to the initial impulse, and owing to the vortex motion the smoke will remain in the ring as long as it is moving. The more rapid the motion the farther the ring will go before breaking up.

"The rings or miniature whirlwinds shot from the vortex gun conform to the behavior pattern of the smoke ring as blown from the mouth. Their size and velocity, and the distance traveled, depend upon the dimensions of the gun and the force with which it is struck. They are always invisible unless smoke or some other visible substance is put in the gun."

A small vortex gun about eight inches in diameter shoots a ring with a diameter of two to three inches. The ring travels around twenty feet a second and its impact can be felt at twenty-five feet. Another gun, which is about six and onehalf feet in diameter, shoots an eighteen-inch ring at a speed of ninety miles an hour. It will snuff out candles at sixty to seventy feet, and at closer range it will upset a man if he is not prepared for the blow.

Engineers are planning guns of twelve to fourteen feet in diameter. They will be fired with a TNT cartridge, and will hurl a four- or five-foot ring one mile at a speed of eight hundred to one thousand miles per hour. This ring will strike an object with devastating power, and probably could knock a bomber out of control. Dr. Thomas believes much bigger guns can be built, so long as a method can be devised to strike the diaphragm with sufficient force.

Before the war is over, Nazi planes may be assailed by manmade tornadoes. In peacetime the vortex gun could, according to Dr. Thomas, be used to rid an industrial area of smoke. He suggests that huge vortex guns might be installed below or above the roof to trap all the smoke from a plant. Automatic hammers would strike the drums at regular intervals, 
and blow huge smoke rings skyward at several hundred miles an hour. Industrial cities would lose their unsightly and disagreeable blanket of smoke and soot; cleaning and painting bills would be cut sharply, and living conditions would be greatly improved.

Fantastic? Yes? Impossible? Impossible is a strong word to use. Perhaps all these predictions will not come true. Perhaps all these will come true, and a score of others. We have not rounded up all of them.

Only the future will tell whether our prophets are right. But, at any rate, they may join a company of distinguished forecasters of "things to come":

Seven hundred years ago Roger Bacon predicted a dozen of the commonplaces of today-which were fantastic impossibilities then. In fact, they were so fantastic, and Bacon knew so well the tenor of his times, that he saved his neck by putting his predictions in a cipher. But recently, when the predictions were deciphered, we found he had envisioned the microscope, the telescope, explosives, and incandescent lights.

In 1887 Edward Bellamy, social philosopher, predicted the radio when he described that a person "merely touched one or two screws, and at once the room was filled with music."

And Eratosthenes of Cyrene, eighteen hundred years before the voyage of Columbus, predicted men should someday sail beyond "the Gates of Hercules" and find the world was round. 


\section{INDEX}

A

Acetic acid, 158, 163

Acetylene, 162

Acids, acetic, 158; amino, 170, 254; carbolic, 160; hydrochloric, 177; naphthoxyacetic, 212; nitric, 163; salicylic, 159; sulphuric, 162, 207

Acrylate resins, 164; Lucite, 35, 36, 164; methyl methacrylate, 150 , 164

Adam, Flight Lieutenant, of Royal Air Force, 84

Aeronca, 60

"Age of Air," 76, 79; health problems of, 259

Agriculture, 157; chemurgy, 199-203, 204-210, 215; electricity on farm, 267; farm buildings, 213-214; "farm problem," 199-200; greenhouse farms, 267-268; hydroponics (soilless agriculture), 211-212; jeep on farm, 51-52, 60, 139, 214; long-term prediction of weather, 213; machinery, 213; TVA programs, 210; transportation, 214

Agriculture, Department of, 2 10; chemurgy, 199-203, 204, 210, 215; Bureau of Home Economics, 216; Bureau of Plant Industry, 212 ; Regional Research Laboratories, 199, 205

Air conditioning, 30-31; aided by cheap electricity, 266; automobile, 42, 44; busses, 108; cities, 266; make civilization move southward, 266267; railroad cars, 103

Airlines, 7, 97-98, 101, 113, 114; and first class mail, 6, 86, 98; and passenger and freight revenue, 85-86; Air Transport Command and Naval Air Transport Service, 87-
88; Eastern Airlines, 86; flexibility of service, 78; glider "trains," 9092; Pan American, 76; Pennsylvania-Central, 8o; seadrome route, $80-$ 8I; speed versus cost, 78-79; United Airlines, 77; Western Air Lines, 88

Airlines, international, 98-100; CAB, 99; Pan American, 98; right of "innocent passage," 99; Trippe, Juan, favors international competition, 98-100

Airplane, cargo and passenger, 9, 78, 89-90, 114, 170, 222; ambulance plane, 234; Consolidated Vultee airliner, 79; deicing equipment, 8182; engines, 86; Kaiser-Hughes $\mathrm{HK}_{1}$, 90; loading techniques for cargo, 88-89; pressurized cabins, 84-85; speed versus cost, 78-79; Stratoliner, 81-82, 84; super-clippers, 76

Airplane, light planes, 12, 60-61, 98, 170; Aerocar, 71-72; Aeronca, 60; Cessna, 60; converted into car, 70, 71; Ercoupe, 74; "grasshopper," 60-6r; how to fly, 72-74; hydromatic propeller, 70, 83; landing gears, 71, 74; Piper Cub, 6o; safe landings at night, 74-75, 141-142; simplified flying, 74-75; Skyfarer, 74; two-speed propeller, 70; wing flaps, 74

Air Transport Command, U. S. Army, 87-88, 98

Airways, Federal, System, 95-97; Alaskan Airways System, 96; Civil Aeronautics Administration, 95 Alaska, in "Age of Air," 80, 87; Airways System, 96

Alchemists, 262; transmutation of matter, 262 
Alcohol, from grain, 153-154; from petroleum, 153, 158

Alkyd resins, I64

Allegheny General Hospital, 244

Alloys, steel, 48, 178, 197; chrome steel, 179; manganese steel, 178; molybdenum steel, 179; nickel steel, 179; stainless steel, 179; tungsten steel, 179; vanadium steel, 179

Altimeter, air pressure, 94; absolute altimeter, 94-95, 142

Aluminum, 48, 49, 107, 158, 166, 174, 175, 197; alloys, 175; Hall process, 174; in body, 219

Aluminum citrate, 267

Ambulance, plane, 234; train, 235

American Institute of Architects, 23

American Institute of Public Opinion, survey of colds, 252

American Bantam Car Company, 5I

American Glass Review, 192-193

American Iron and Steel Institute, 184

American Rocket Society, 93

Amino acid, 170, 249-250, 254

Ammonia, high-pressure synthesis of, $157,161,2$ ro

A.M. ("amplitude modulation") radio, 143,147

Anesthesia, regional, 256

Anheuser-Busch, Inc., 227

Aniline, 160; dyes, 159

Annealing, 193, 195

Antiaircraft guns, controlled by $\mathrm{Ra}$ dar, 121

Antibodies, 222; proteins, 202, 221

Apartments, 23; prefabricated units, 24-26

Appliances (See Household)

Aralac, 170, 202

Architectural Forum, on acoustics, 32-33

Arctic Ocean, in "Age of Air," 79

Armstrong, Edward R., 80

Army Air Corps, United States, 69, 84, 98; super-bomber, 85

Army Medical Corps, United States, 167; experiments with penicillin, 243-244; hospitals, 228, 230-232, 234 ,
235; rehabilitation of wounded, 237; sulfathiazole prophylaxis, 24I242; training of doctors, 236

Army Signal Corps, United States, I20, 140, 167

Army, United States, 105-106, 167; "health bomb," 242; recovery of wounded, 228

Arnold, General H. H., 85

Aromatic hydrocarbons, 155

Arsenic drugs, mapharsen, 241; salvarsan ("606"), 238

Arthritis, 256

Association of American Railroads, Car Service Division, 106

Atabrin, 247

Atmospheric pressure, 82-84, 94

Atom, radioactive, 257; atomic energy, 261-262; "made to order," 263-264; smashing, cyclotron, 262263

Autogiro, 6o; compared to helicopter, 69

Autoejector, for revival of dead animals, 255

Automobile, 6, 42-59, 101; and jeep, $5 \mathrm{I}-52$; cost of postwar cars, 4647 ; engine, 44, 46; high-octane gasoline, 54-55; light metals, 53-54; plastics and plywood, 43, 52-53, 54; safety on highways, $43,56-57$; stylists versus engineers, $45-46$; visibility increased for driver, 43

Automobile industry, $15,26,45-46$, 97; competition with aviation industry, 58-59; problem of tools and dies, 58; postwar dilemma, 57

Automotive Engineers, Society of, III

Aviation industry, 97; Boeing Stratoliner, Flying Fortress, 84-85; Consolidated Vultee, 79; Grumman Aircraft Corporation, 90; KaiserHughes $\mathrm{H}-\mathrm{K}_{1}, 90$; influence on automobile design, 44; on furniture designs, 35; light planes, 60; Mars flying boat, 77; postwar prospects, 97-98; use of plastics, plywood, 53 , 166, 191; plasticized paper, 187 
Avidin, 25 I

Axes, vertical, longitudinal, lateral of plane, 72-74

B

Babb, Charles H., 89

Bacon, Roger, 272

Baird Company, 134

Baldwin, Hanson W., 121

Banting, Sir Frederick, 85

Bathrooms, 36-37

"Bathtub butyl," 155

"Battle of Britain," 85

Battleship, 173; plastics in, 150 ; radio equipment, 140; use of Radar, 121 Bauxite, 174

Beechnut Packing Company, 223

Beefsteak, synthetic, 227

Bel Geddes, Norman, 15

Bellamy, Edward, 272

Bellevue Hospital, Cancer Division of, $25 \mathrm{I}$

Bell Telephone Laboratories, $162-163$

Belmont Iron Works, 8r

Benjamin, Dr. Harry, 258-259

Benzol, 160-161

Bergius, Professor Friederich, 189190

Beryllium, 18I-182; copper alloy, 48, I82; nickel alloy, 49, 182; safety tools, 182 ; work on aluminum and magnesium alloys, 49,182

Better Homes and Gardens, 269

Bigelow-Sanford Carpet Co., Inc., 205

Biggers, John D., 197

Biotin, 250; avidin, 25I; cancer research, $25 \mathrm{I}-252$

Blauvelt, Hiram, 259

Bliven, Bruce, 263

Bloeth, William, i ro

Blood, cells, 230; disease treated with radioactive phosphorus, 263 ; red cells used on wounds, infections, 254

Blood, clotting of, 236; $M^{\prime}$ rays "broadcast" by, 258
Blood, donor, 230-231, 253-254

Blood and Plasma Exchange Bank, 253-254

Blood, plasma, 87, 227, 228, 230, 23r; Blood and Plasma Exchange Bank, 253-254; preparation of, 230 ; substitute for, 254

Blood, types, 230

Boeing Aircraft Company, 84-85

Boeing B-17 Flying Fortress, 43, 84$85,141,150,172$

Boiling point, 84

Borsook, Henry, 218

Bothezat, George de, 67-68

Brain, surgery, 257

Brass (copper, zinc), 180

Brazil, 168

Bread, enriched, 217

British Broadcasting Company, 134

British Journal of Experimental Pathology, 244

British Overseas Airways, 98

Broadcasting, sound and television, 136-137; "band," 146-147

"Broken stowage," in cargo-ship loading, I IO-II I

Bronze (copper, zinc, tin), 180

Brooklyn Polytechnic Institute, I9o

Browning, Robert, "Andrea del Sarto," 26r

Budd, Edward G., ro3, 108

Building and Loan Associations, 2728

Building codes, 27

Buna N type, synthetic rubber, 154

Buna S, synthetic rubber, 152, 153I54

Bureau of the Census, 135

Bureau of Mines, 183-184

Bushnell General Hospital, 243

Business, opportunities in postwar period, $8,10,11,98$

Busses, IoI-ro2; NRPB report on, I08; postwar designs, 108

Butadiene, $153,161,162$; and furfural, 207

Butyl, synthetic rubber, 155

Butylene gas, 212 


\section{C}

Caffelite, plastics, 168

Calcium, radioactive, 263

California, University of, Medical School, 252

Camm, F. W., Television Manual, I34

Campbell, Major General Levin H., 184

Camphor, synthetic, 168, 209

Campini, Signor, 93

Cancer, research with biotin, 251-252

Cannon, Dr. Paul R., 22 I

Cans, edible, 268-269

Catalyst, 153

Caproni Airplane Company, 93

Caravan, C-76, 89

Carbon, 158; compounds of, 158-159, 164; in Foamglas, 195; in steel making, 178

Carlisle Barracks, Pennsylvania, 23 I

Carver, Dr. George Washington, 200-201

Casein, 202, 254

Castor beans, 203

Cellophane, 165

Cells, 158, 257; cancer, 251-252; $M$ rays, $275-278$

Cellulose, 158; 189; from castor beans, 203; from corn, 206; from cotton linters, 204-205; wood, 208

Cellulose acetate, 163 ; Tenite, 165

Cellulose nitrate, $16_{3}$; celluloid, 163

Celotex Corporation, 14

Cessna, 60

Chemical industry, 149, 166-167; aids farmer, 268; indispensable, 171 ; in two wars, $167-168$

Chemigum, 154

Chemistry, 149-171; chemurgy, 199203, 204-210, 215 ; coal-tar by-products, 159-162; petroleum by-products, 162; plastics, 4, 5, 35-36, 43$44,52-53,103,107,108,124,149-$ $150,157,162-167,168$; recovery of low-grade ores, 183-184; synthetic rubber, 151-156; war job of, 166167
Chemurgy, 199-203, 204-210, 215; castor beans, 203; cotton linters, 204-205; corn, 206; flax, 204; peanuts, 20r; sweet potatoes, 200-20r

Chia, 204

Chicago, University of, 221

Childbed fever, 238

Chile, 168

Chlorine, 164, 175, 177

Chloroform, 162

Christian Science Monitor, 192, 200, 268-269

Chromium, 48, 179

Chrysler Corporation, 14, 46

Cigarette paper, from flax straw, 203

Civil Aeronautics Administration, 9597, $113-114$

CAB (Civil Aeronautics Board), 6, 78, 92, 99

Civilian Defense, Office of, 167

Clay, 158, 174, 175

Closets, mass-produced, 35

Clothes, 168-170; from soy bean, 203; from wood, 190

Coal, bituminous, 159; by-products of, 159-162; chemicals, 160-161; drugs, 159-160; dyes, 159; tar, 153 , 157

Coaxial cable, for television, 133,147

Coffee, 168

Coghill, Dr. R. D., 243

Coit, Elisabeth, 23, 36

Coke, 160; coal, bituminous, 159

Colchicine, 213

Colds, 252, 253

Colebrook, Dr. Leonard, 238

Cooking, utensils, 39; electronic, 270

Cooling, radiant, 34

Collectivism and individualism, 9

Combustion, 48, 50, 93

Commutation service, by airplane, 9 ; by helicopter, 6, 7, 67

Conservation, of forests, 192

Consolidated Vultee Corporation, 79; Liberator B-24, 85

Convertaplane, 69-70

Copolymer, 153 
Copper, 180; beryllium-copper, 48, I8I

Corn, cobs and stalks, 206; waxy, 202

Corning Glass Works, 192, 194, 195, 196

Cotton, 189, 200-201, 205-206; cellulose from, 205; leather, 205; roads, 206; tire carcasses, 206

"Cracking" of petroleum, for highoctane gasoline, 55

Cryolite, 174

Current, alternating and direct, 117I1 8

D

Dahlberg, Bror, 14

Davis, Dr. Harvey N., 187

Davies, W. W., 77-78

De Forest, Lee, 132

De Haviland, Mosquito bomber, 53, I9I

Dehumidifier, 34

Dehydrated foods, 222-225

Dehydrator, home equipment, 224225

Deicers, $8 \mathrm{I}-82$

Deserts, 212; use of photovoltaic cells on, 264

Detonation, "knock" in engines, 54

Deville, Sainte-Claire, 174

Dicoumarin, 256

Diesel, Dr. Rudolph, 49

Diesel, engine, 49-5I, 50-51, 102-103; in cargo and warships, II I-I I 2

Diet, 216; education, 217; foods, 168, 216-227; minerals, 218, 210-220; vitamins, $218,219-220$

Dietz, David, 45, 199-200, 238

Diode, 117

Domagk, Dr. Gerhard, 238

Donald McKay, motor ship, II I

Douglas transports, 89, 92

Dow Chemical Company, 154, 164, 176,269

Dowmetal, 177

Dow, Willard, 177, 269

Drugs, coal-tar, 159; aspirin, 160; atabrin, 160; phenacetin, 160; salicylic acid, 159; sulfanilamide and derivatives, I60; sulphonal, I60, 229, 230, 231, 232; veronal, 160

Dubos, Dr. René J., 245

Duffus, R. L., 175

Du Pont de Nemours, E. I., 45, I54, I57, 264

Duralumin, 175

Dyes, coal-tar, 159; alizarin, 159; mauve, 159; synthesis of indigo, Tyrian purple, 159; from petroleum, 162

Dysentery, 240

\section{E}

Ear, plastic reconstruction of, by Drs. Valdes and Schulhof, 255

Eastern Airlines, 86

"Edison effect," 116

Edison, Thomas A., 116, 132

Egyptians, 20-2 I

Ehrlich, Dr. Paul, 238

Electricity, 174-175, 261-262; on farm, 267; generated by thermocouples, 265; photovoltaic cell, 264; transmission of high voltage direct current, 118; transmitted by radio, 265-266; Steinmetz' prediction on cheap electricity, 266

Electrocardiograph, 130

Electronics, 5, 115-131; cooking by, 270; electrosurgical apparatus, 257; radio, 34, 132-133; television, 132, 133-148

Electron, ${ }_{116} 6$; as catalyst, 264 ; "chemotronics," 264; current, 261-262; gun, 145-146; microscope, 131, 252, 257

Electron tubes, 117; diode, 117; colorimeter, 130; iconoscope, 145-146; photoelectric tube, 125-128; spectrophotometer, 126-127; stroboscope, 129-130; thyratron, 117-118

Elements, used by chemist, 158

Engine, automobile, air-cooled, 47; Diesel, 49-51; efficiency of, 50; high-compression, 48; high-octane gasoline, 54-55; "pancake" style, 
44; rear-engine installation, 44; Flying, simplified, 72, 74; at night, weight, 47

Engine, aviation, 86; "flat-opposed," 70 ; light plane, 60, 70; Wright $\mathrm{Cy}$ clone, 77; rocket motor, 93-94

Engineering and Research Corporation, 74

Eratosthenes of Cyrene, 272

Erosion, water and wind, 200, 210; after first World War, 2 I I

Erysipelas, 242

Ether, 162

Ethyl cellulose, 166

Ethylene dicholoride, 162

Ethylene glycol, 162

Eugenol, 158

Europe, protein deficiency in, $221-$ 222

Evans, Colonel Edward S., 79-80, 9I -92

Evans Products Company, 79

Expansion, coefficient of, 194

Explosives, 159; cotton linters for, 204, 205; dynamite, 204; nitrogen for, $167-168$; predicted by Roger Bacon, 272; TNT, 160, 161, 162

Eyestrain, and better lighting, 29-30

\section{F}

Factory-residential towns, 214

Farbenindustrie, I.G., 238, 247

"Farm problem," 199-200

Fatigue, measured by $M$ rays, 258

Federal Government, compromise building code, 27

Fellows, Julian R., 31

Fertilizer, 157, 160, 161, 167, 210

Fiberglas, 195-196

Flax, straw, 203

Fleming, Dr. Alexander, 242

Fleming, Professor J. A., I16, 132

Fleming valve, II 6

Florey, Dr. H. W., 243

Fluorescent lighting, 29-30, 40, 103, 267

Fluorine, prevents tooth decay, 269; in production of cryolite, 174

Flying boats, $76-77,88,90,98$

74-75

Foamglas, 195

Food, 168, 216-227; bread, enriched, 217 ; dehydrated, 222-225; diet, 216 , 218, 219-220; "mechanical cow," 226-227; peanuts, 20r; soy beans, 203; storage of, 195; sweet potatoes, 200-20I; uneducated buying of, 218; utility companies, 269; waste of, 217,219

Food Distribution Administration, 217,219

"Food for Freedom," 2 II

Forbes magazine, 183

Ford Motor Company, 52, 53, 168

Formaldehyde, 162, 163

Fowler, Harlan D., 89-90

Fractures, "closed treatment" for, 232-234

F.M. (frequency modulation) radio, 143,147

Fortune magazine, 37

Fort Worth Press, 52

Froesch, Charles, 86

"Froth flotation," 184

Fuller, R. Buckminster, 16-17

Furfural, 206-207

Furnace, smokeless, 31-32; oilburning, $4^{\circ}$

Furniture, 34-35, 165

\section{G}

Gahagan, Andrew J., I82

Galdston, Dr. Iago, Bebind the Sulfa Drugs, 237, 238, 242

Gas gangrene, 240-24I

Gasoline, high-octane, 42, 54-55, 109; "triptane," 55; hydrocarbons, 162, I7 1

Gelmo, P., 238

General Aircraft Corporation, 74

General Electric Company, 82

General Electric Research Laboratories, $118,177,186$

General Hospital of Catalonia, 233

General Motors Corporation, 14, 50

General Tire \& Rubber Co., 151-152 
Gerard, Ralph W., 255, 257

Geriatrics, 258

Gericke, Professor W. F., 21 1-212

Germany, chemical leadership lost to U. S., 168; wood chemistry program, 188

Gerontology, 258

Gerontotherapy, 258-259

Gilbert, Jr., Cass, 18, 19

Glass, 5, 40, 57, 185, 195, 197, 198; Fiberglas, 195-196; Foamglas, 195; for tire cord, 43; optical, 196, 197; production research, 196; Pyrex, 194; how flame-proof glass is made, 194; Vycor, 194

Glesinger, Egon, Nazism in the Woodpile, 188-190

Glider, "trains" for freight and passengers, 5, 90-92, 98, 108; first flight across Atlantic, 92

Goddard, Dr. R. H., 93

Goering, Hermann, 188-189

Gold, 180-181; photovoltaic cell, 264

Gonorrhea, 24I; prophylaxis, 24I242

Goodyear Tire \& Rubber Company, I 54

Graf Spee, 111

Gramicidin, 245-246

Granite (feldspar), 158

"Grasshoppers," liaison planes, 60-6I

Gravity, center of, 44

Great American Desert, 212

"Great Circle" routes, 79-80

Great Lakes, 106

Great Salt Lake, 176

Greenland, 174

Gregory, Colonel H. F., 65

Grid, 11 8-1 19, 132

Gropius, Dr. Walter, 214

Grumman Aircraft Corporation, 90

Guild, Lurelle, 108

Gun metal (copper, tin), 180

Gunnison Housing Corporation, I9I

\section{H}

Haldane, J. B. S., 255

Hall, Charles Martin, I74
Hallett, Robert M., 192

Halstead, William S., 56

Hamby, William, 38-4I

Harrington, Dr. H. H., 177

Heating, radiant, 20, 33-34

Heilman, Dr. Dorothy, 245

Heiser, Dr. Victor G., 218

Helicab, 68-69

Helicopter, 2, 12, 60-67; amphibian, 63; Convertaplane, 69-70; de Bothezat model of, $67-68$; for air mail and express, 6, 66; for commuters, $6,7,66$; Helicab, 68-69; how to fly it, $6 \mathrm{I}-63$; postwar possibilities, 66 67; traffic control by, 56; used against submarines, 65

\section{Hemp, 204}

Heparin, 256

Herbs, 204

Hercules Powder Company, 150

Herrell, Dr. Wallace E., 245

Herrick, Gerald P., 69-70

Herty, Dr. Charles E., 208

High altitudes, protecting pilot at, 83-85

Highways, planned for safety, 56

Héroult, Paul L. T., 174

Hitler, Adolf, 188-189

Hogben, Lancelot, Science for the Citizen, 161-162, 211

Holden, Arthur C., 26-27

Holt, Rackham, 200-201

Home, average, 29

Home Economics, Bureau of, 216

Hormones, 259

Hospital, 228; battalion, 230; base, 234; collecting station, 232; corpsman, 229; field, 232; mobile equipment, 231-232, 235; rehabilitation of wounded in, 237; ship, 236

Household, appliances and furnishings, 29-41, 175, I78; air conditioning, 30-31; bathrooms, 36-37; closets, 35 ; cooling, radiant, 34 ; furnace, smokeless, 31-32; furniture, built-in, 34, new designs, 35 ; glass, 195, 197, 198; heating, radiant, 3334; kitchen, 38; "kitchenless house," 38-41; lighting, 29-30; Precipitron, 
30-31; soundproofing, and better acoustics, 13, 32, 33

Houses, prefabricated, 6, 12-22, 170; building codes, 27; construction of, 12, 13; for farms, 214; foundation of, 12, 17; land renting for, 17, 26; standardization, 15, 26; use of glass in construction of, 195, 197, 198; use of light metals, plastics, plywood, 28, 165, 175, 178; used for war workers, 13; utility unit, 12

Hunt, James F., 264

Hurricane, 119

Huse, William, 218

Hycar, 154

Hycar Chemical Company, 154

Hydrocarbons, 55, 93; aromatic, 155, 162; liquid, 171

Hydroelectric plants, 174-175

Hydrogen, 158, 164; in cyclotron, 262

Hydroponics (soilless agriculture), 2 II-212

Hypertension, 256

Hypodermic, 229

\section{I}

Illinois, University of, $3 \mathbf{I}$

Illustrated London Nerws, The, 138

Incandescent light, 30, 116, 179, 181; predicted by Roger Bacon, 272

India, diet of people, 218

Indigo, natural, 156 ; synthesis of, 159 Indium, $18 \mathrm{I}$

Individualism, 9

Industry, 2-11; chemistry in, 171; electronics in, 117-119, 122-131; transmission of power by radio, 265-266

Influenza, 252-253

Inland waterways, 101, 106

"Innocent passage," right of, 99

Inoculation, 228-229, 249, 259

Insecticides, 204, 259; "health bomb" to fight mosquitoes, 247

Iodine, radioactive, 263

Ionosphere, 120, 133

Iowa State College, 200 lowa, U.S.S., III

Iron, $178,180,181$; in diet, $219-220$; radioactive, 263 ; photovoltaic cell, 264

Isoprene, 152

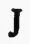

Japan, 124, 168

Jeep, 51-52, 60, 139, 214,232

Jeffers, William M., $15 \mathrm{I}$

Johns Hopkins Hospital, 239

Joslin, Theodore, 3, 4

Journal, American Medical Association, 241-242, 244

JU-88, 93

$\mathbf{K}$

Kaempffert, Waldemar, 253, 266, 268

Kaiser, Henry, 16, 90, 102-103, 109

Kaiser-Hughes $\mathrm{H}-\mathrm{K}_{1}$ Flying Boat, 90

Kaplan, Professor Ira I., 25 I-252

KDKA, 132

Keck, George Fred, 19, 20-2 I

Keefer, Dr. Chester S., 246

Kerr, Dr. William J., 252

Kettering, Charles F., 50-5 I, 266

"Kitchenless house," 38-4I

Kiev, Russia, 63

Kiev, University, $\sigma_{3}$

Knight, Dr. Henry G., 208-209

"Knock" (detonation), in engines, 54

Kochalaty, Dr. Walter, 245

Koch, Dr. Robert, 249

Koegel, Professor Fritz, 250

L

Laboratories, Regional Research, 199, 205, 243

Laboratory, bacteriological, 235; dental, 235; optical, 235

La Guardia Field, 66, 90

Lamp, incandescent, 30, 116, 179, 181; aluminum citrate light, 267; bacteria destroyed by, 5, 30, 131; controlled by phototube, 30,127 ; fluorescent, 29-30, 40, 103, 267 
Land, Admiral Emory S., 112-1 13

Landing gear, 71, 74

Land, renting of, 17, 26

Landing strips, for planes, 56; "flyways," 97

Langewiesche, Wolfgang, 86, 97

"Laundering" the air, with Precipitron, 30

Lead, $18 \mathrm{I}$

Lederle Laboratories, 243

Leith, Dr. C. K., 183

Lend-Lease, 105, 106, 217,235

Lewisite, 155

Libbey-Owens-Ford Glass Company, 197

Life, 138

Life Insurance Companies, 27-28

L'Illustration, 138

Life, expectancy, 258; gerontotherapy, 258-259

Lignin, 208

Liners, ocean, 114

Linseed oil, 204

Lippman, William A., Jr., 88

Lissitzyn, Oliver J., International Air Transport and National Policy, 100

Lithium, I8I

Little, Arthur D., Inc., Industrial Bulletin, 206, 244-245

Loading techniques, for airplanes, 8889; for cargo ships, I10-III

"Locomotive" plane, 5, 90-91, 98

Loening, Grover C., 90-91

Lohr, Lenox R., Television Broadcasting, 136-139

Long, Dr. Perrin, 239

Lovette, Captain Leland P., 65

Lucite, 35-36, 164, 256

\section{M}

Mack Truck Company, 107

Madder, 159

Magee, Major General James C., 243

"Magic bullets," 238, 242

Magnesium, 48, 49, 107, 177-178; "mined" from ocean, 176-177

Mail, first class, to go by air, 6, 86, 98
Malaria, 247, 248; problem in "Age of Air," 259

Manchester, Harland, 183

Manganese, 48, 178

Mantell, C. L., Sparks from the Electrode, 177

Mapharsen, 24I

Maps, mercator-type, 79

Maritime Commission, United States, 65, 111,112

Marks, Robert W., 183

Martin, Glenn L., 76-77, 97-98

Massachusetts Memorial Hospital, 246

Mayo Clinic, 245

McMillen, Wheeler, 200

"Mechanical cow," 226-227

Medical Society of the County of New York, 253

Medical World, The, 258-259

Medicine, wartime, 228-237; atabrin, 247; "closed treatment" for fractures, 232-234; gramicidin, 245; penatin, 245; penicillin, 242-245; plasma, 227, 228, 230, 23 I, 253; sulfa drugs, 229, 230, 231, 232, 237-242; surgery, 232, 233, 234, 236, 255, 257

Melamine resins, 167

Meningitis, 241; haemophilus influenzae, 241; meningococcus, 241; streptococcus, 241

Merchant Marine Act of 1936, 109, 112

Merchant Marine, United States, I00, 109, 112

Merck \& Co., 243

Mergenthaler Linotype Company, 196

Merrill Lynch, Pierce, Fenner and Beane, 171, 267

Metals, lightweight, 6, 42, 48, 103, 170, 172-178 (See Aluminum, Magnesium)

Metallurgy, 49, 170, 179-180, 182, I84; powder, 182-183

Meteorology, 213

Methanol, 160

Methyl methacrylate, 150, 164, 256

Metycaine, 256 
Meyer, Dr. A. J., 243

Micarta, 166

Microphone, 143-144

Microscope, 263; predicted by Roger Bacon, 272

Midgley, Dr. Thomas, Jr., 55

Miles, J. C., 3 I

Milk, 202, 226; Aralac, 170, 202; casein, 202; "mechanical cow," 226 227

Minerals, in diet, $218,219-220$

Minneapolis-Honeywell Co., 196

"Mitogenetic rays" ( $M$ rays), discovered by Russian Dr. Gurwich, 257-258

Molybdenum, 48, 179

Monel metal (copper, nickel, iron), 180

Monomer, 152

Monro, C. Bedell, 8o-8r

Monroy, Johann Albrecht von, 188189

Monsanto Chemical Company, 165

Moss, Dr. Sanford B., 82

Motion picture industry, 33, 146

Mudd, Major Richard D., 23 I

\section{$\mathbf{N}$}

Naphthalene, 16r

Naphthoxyacetic acid, 212

Nash-Kelvinator Corporation, 14

National Association of Manufacturers, 206, 214-215

N.E. (National Emergency) steels, 179-1 80

National Farm Chemurgic Council, 200

Naval Research Laboratory, 120

National Resources Planning Board (NRPB), 27, 106, 108, 215

Naval Air Transport Service, 88, 98

Naval stores industry in South, 208209

Navy, United States, 88, 98, 1 I I, 197; battleships, 173, 12 1, 140, 150; equipment, 235; hospital ships, 236; recovery of wounded, 228 ; rehabilitation of wounded, 237; penicillin, experiments with, 244; sulfathiazole prophylaxis, 241-242

Nelson, Paul, 21,22

Neoprene, 154, 161, 162, 165

Nerve, operations, 256

Neurosurgeon, 256

New Jersey Agriculture Experiment station, 246

New Republic, 263

News, television broadcasting of, 138 Newsweek, 122

New York City, traffic congestion, 56

New York Herald Tribune, 176, 259

New York Times, 85, 121, 156-1 57, 253, 255, 266

New York Times Magazine, 175

New York University, College of Medicine, 251

New York World-Telegram, 45, I 10, 196

Nickel, 179, 180

Nitrogen, 167, 168; and biotin, 250; changed to hydrogen by "bombardment," 262

Noctovision, 134

Normandie, 114

North African campaign, recovery of wounded in, 228

North American P-52 Mustang, 172

Northern spruce, 208

North Pole, "crossroads of commerce," 79

Nylon, 160, 169, 256

\section{O}

Oat hulls, 206; furfural, 206-207

Oberlin College, 174

Ocean, 158; storehouse of minerals, 175-176

Ogburn, William F., 266-267

Old age, diseases of, 258-259; gerontotherapy, 258-259

O'Neill, John J., 176

Onion root "broadcasts," 257-258

Ontario Paper Company, 207

Optical glass, 196

Ores, low-grade, 183 
Orr, Dr. Winnett, 232-233

Osmium, 18r

Osteomyelitis, 233; treated by penicillin, 243

Othmer, Dr. Donald F., 190

Ott, Dr. Emil, 150-15 I

Owens-Corning-Fiberglas, 196

Oxford University, 243

Oxygen, 158

\section{$\mathbf{P}$}

Packard Motor Co., 44

Pan American Airways, 76, 98

Paper, 5, 198; aqualized, 186-187; chemical vapor treatment, I86; plasticized, 187; war jobs, 185-186

Parachutes, I6r

Parking, of cars, 56

Pasteur, Louis, 249

Patterson, W. A., ror

Peanuts, products from, 20r

Penatin, 245

Penicillin, 242; effective against staphylococcus, 243; for venereal disease, 244; penatin, 245; penicillium notatum, 242; production problems, 244

Penicillium notatum, 242, 245; mold used directly on infections, 244

Penney, Gaylord W., 30-3I

Pennsylvania-Central Airlines, 80

Pennsylvania, University of, 245

Perbunan, 154

Perilla, 204

Perkin, William, 159

Petroleum, 162; chemicals from, 162, 164, 165; high-octane gasoline, 162; hydrocarbons, $55,93,162,171$

Pfizer, Charles, \& Co., 243

Phenol (carbolic acid), 160

Phenolic resins, 163, 166; bakelite, 163

Phillips Petroleum Company, 154

Phosphors, 29

Phosphorus, radioactive, 263

Photoelectric tube, 125-128

Photographic film, r68; from corn cobs, stalks, 206
Photography, use of photoelectric tube in, 127

Phthalyl-sulfathiazole, 240

Pipe lines, ror

Piper Aircraft Company, 70

Piper Cub, 60

Piper, W. T., 70-71, 72

Pitcairn-Larsen Autogiro Company, 69

Pittsburgh Plate Glass Company, 194195

Plank Panel house, 18-19

Plant Industry, Bureau of, 212

Plants, war, 29; electron tubes speed production in, $125-130$

Plasmochin, 247

Plastics, 4, 5, 35-36, 43-44, 52-53, 103, $107,108,124$; future of, 157 ; molecules of, 162-163; thermoplastic, 163; thermosetting, 163-164

Plywood, 53, 107, 108, 190-r9r; plastic-bonded, 170, 190, 191, 208; R. F. heating of, 124

Pneumococcus, 240

Pneumonia, 239, 240

Polybutene, 165

Polymer, polymerization, 152

Popular Science, 270

Potatoes, sweet, products from, 200201

Potatoes, white, produce starch for industrial use, 202

Potentiometer, 267

Powder metallurgy, 182-183; self-oiling bearings, 183; "sintering," 182

Precipitron, 30-31

Prefabrication, in housing, 6, 12, 22; in shipbuilding, ro9-r ro

Pressurized cabin, for high-altitude flight, 84-85

Pressure suit, for high-altitude flight, 84

Prontosil (see Sulfanilamide), 238

Prophylaxis, sulfathiazole, $24^{1-242}$

Propeller, hydromatic, 70, 83; production of speeded by R.F. heating, 124

Protein, 202, 221; deficiency, 221-222; in wool, 238; soy beans, 202 
Public Affairs Committee, 18

Public Health, 248-249; in "Age of Air," 259; Service, 259

Public Service Company of Chicago, 224

Pullman Car \& Manufacturing Corporation, 102

Pushee, H. B., 151-152

Pyrex, 194

\section{Q}

Quaker Oats Company, 206

Quartz, 158

Queen Charlotte's Hospital, 238

Queen Mary, 114

Quinine, substitute, 246; atabrin, 247

$\mathbf{R}$

Radar (Radio Detecting and Ranging), 142; aid to aviation, 95 ; as aid to motorist, 57; at Pearl Harbor, 120; in "Battle of Britain," 119; operation of, 120-121; postwar uses, 121-122; tantalum used in, 181

Radiator, automobile, 46

Radiator, home, 33

Radio, 34, 132-133, 142-144, 148; absolute altimeter, 94-95; beams to guide motorists, 57; for liaison planes, 6r; range and marker stations, 95; safety in blind-landings, 141-142; Signal Corps equipment, 139; superradio stations of CAA, 96; traffic control, 56

Radioactivity, 263

Radio City Music Hall, 19

R.C.A. Radio-Electric Laboratories, I16

Radiodynamic control, of ships, 268

Radio frequency (R.F.) heating, 122124

Radio industry, in wartime, $139-142$

Radium, 257, 263

Railplane, 102

Railroads, 7, 8, 101-106; and cheap electricity, 268; "Battle of Transportation," 104-106; Diesel engines,
103; history of, 101; improved locomotives, ro3; lightweight cars, 102-103; Railplane, 102; turbines, 103

Ramie, 204

Rationing, 225

Rations, U. S. Army, 223-224, 226227, 269

Raw materials, crisis in, 3, 4

Rayon, 43, 205

Reduction gears, in airplane engine, 83

Refinery, 162; gases, 162

Refrigerator, 37-38; thermocouple, 265

Remmelkamp, Dr. Charles H., 246

Republic P-47 Thunderbolt, 173

Research and Planning Associates, 24

Richards, Dr. A. N., 244

Rich, Leo H., 57

Robinson, Dr. George H., 244

Robinson, Admiral S. M., I73

Robsjohn-Gibbings, T. H., 34-35

Rockefeller Institute for Medical Research, 218

Rocket power (jet propulsion), 93; operation of rocket motor, 93

Roebling, John A., Company, 81

Rohde, Gilbert, 34

Roosevelt, Jr., Franklin D., 239

Rosin, 209

Rubber, natural, 151, 164; compared with synthetic, 152, 154, 155, 165; future of, 156-157; plantations, 151 , 156

Rubber, synthetic, 151-156; Buna S, 152-154; Buna N, 154; Butyl, 155; furfural as solvent, 207; Neoprene, 154; postwar prospects of, 156; Thiokols, A, B, and FA, 155; Thiokol RD, 154; Uskol, 154

Rutgers University, 246

Rutherford, Sir Ernest, 262

\section{S}

Salesmen, in postwar period, 8, 98

Salicylic acid, 159

Sanders, Walter B., 24-26 
Saran, 164-165

Sarnoff, David, 94

Savings banks, 26-28

Scarab car, 47

Schmidt camera, 136

Science Digest, 117

Scientific Research and Development, Office of, 243

Scripps-Howard newspapers, 199, 238

Seadromes, 80-81

Selenium, 181; photovoltaic cell, 264 Servicemen, in postwar period, 8, 98 Seys, Squadron Leader R. G., of Royal Air Force, 92

Shaver, Dr. W. W., 194

Shipbuilding, 109-1 10

Shipping, postwar policy of U. S., I1 2; tramp shipping, I 12

Ships, cargo, 109-111; liners, 114; radiodynamic control of, 268

Shock, 230; plasma transfusions, 231

Shoe soles, of cotton, 205

Siemens Halske, 182

Sikorsky, Igor I., 7, 61-63, 64-65, 6667

Silicon, 158, 181, 194

Silver, 180

Sinus infections, treated with gramicidin, 246

Small, Captain Lisle F., III

Smith, Geddes, Plague on Us, 248-249

Smith, J. Kent, 182

Smith, M. W., 103-104

Smoke, cleared from air by vortex gun, $271-272$

Soap, 209

Socony-Vacuum Oil Company, 54

Sodium, 152, 174

Sodium sulphate, 193

Soil conservation, 2 I0

Solomon Islands campaign, recovery of wounded in, 228, 236

Soundproofing, 13, 32

Sound waves, 143

Southern Friction Materials Company, 205

Southern pine, 208

Soviet Institute of Experimental Biology, 255
Soy beans, 168; products from, clothing, 203; cosmetics, 203; foods, 203; house furnishings, 203; industrial materials, medicines, 203; rich in protein, 202

Spanish Civil War, 233

Spann, Colonel George F., 248

Spectrophotometer, 126-127

Spitfire, 85, 119

Squibb, E. R., \& Sons, 243

Stall, in flying, 74

Standardization, importance of in low-cost products, 26; in houses, 15

Standard of living of all must be raised, ro

Standard Oil Company of New Jersey, 154-155, 165

Stanton, C. I., $113-114$

Staphylococcus, 240; penicillin effective against, 243

Steam engine, efficiency compared with Diesel, 50; improved steam locomotive, 103-104

Steam-power plant, efficiency of, 50

Steel, lightgauge, for automobile bodies, 53-54; for trailers, ro8; for railroad cars, 103 (see Alloys)

Steinmetz, Dr. Charles P., 266

Stevens Institute of Technology, 187

Stine, Dr. Charles M. A., 45, 157, 26r Stokley, James, Science Remakes Our World, 118-119, 134-136, 264

Stout, William, 47, 48, 68-69, 70, 7172, 102

Stratoliner, Boeing, 81-82, 84, 85

Stratosphere, problems of flight in, 83-85

Streptococcus, 239, 240, 246

Streptothricin, 246

Stroboscope, 128-129

Styrene, 153, 16r

Submarine, III-1 I2; hunted by helicopter, 65, Radar, 120

Subway, Sixth Avenue, New York City, 32

Sugar, from wood, 5, 189-190

Sulfadiazine, 229, 239-240 
Sulfaguanidine, 240

Sulfamerazine, 240

Sulfanilamide, 160, 229, 230, 231, 232, 237-240; derivatives, 239-240; how they fight bacteria, 242; toxic reactions studied, 242

Sulfapyridine, 239

Sulfasuxidine, 240

Sulfathiazole, 239; prophylaxis, 241242

Sullivan, Louis, 19

Sulphite liquor, produces alcohol, 207, 208

Sulphuric acid, 162, 207

Sun, energy from 162,264 ; harnessing rays of, 264

Sun Shipbuilding \& Drydock Company, 80-8r

Supercharger, for airplane engine, 82

Surgery, 232, 233, 234, 236; autoejector, 255; brain surgery, 257; cure for deafness, 255; for hypertension, 256; nerve operations, 256; regional anesthesia, 256; transplanting of organs, 255; treating arthritis, 256; use of heparin, dicoumarin, 256; use of "radio knife," 257

Sutures, 196, 256

Swain, Squadron Leader, of Royal Air Force, 84

Synthesis, in chemistry, 157,159

Syphilis, treated with mapharsen, 24r; salvarsan, 238

\section{$\mathbf{T}$}

Tachometer, 62

Tank, M-4, 45, 178

Tankers, oil, 105

Tantalum, 181

Tapioca, 202

Taylorcraft, 60

Taylor, Dr. A. Hoyt, 120-12 I

Taylor, Dr. W. C., 192-193

Teague, Walter Dorwin, 15, 16, 37

"Teco" ring, ror

Teeth, decay checked by fluorine, 269
Telephone, 143

Telescope, 196; predicted by Roger Bacon, 272

Television, 132, 133-148; cost of sets, 138; how it works, 144-147; networks, 135, 139; noctovision, 134; problem of high-frequency waves, 146-147

Tellurium, i8r

Tennessee Eastman Corporation, 165 Tennessee Valley Authority (TVA), 15, 175, 210

Tesla, Nikola, 268

Tetraethyl lead, 55

Textiles, synthetic, 9, 157; Aralac, 170; from soy beans, 168; from wood, 189, 190; nylon, 160, 169; rayon, 169; Velon, 169; vinylidene chloride, 169; Vinyon, 169

Thermocouple, to generate electricity, 265; for refrigerator, 265

Thermionic emission, 116

Thermoplastics, 163

Thermosetting plastics, 163-164

Thiokol Corporation, 154

Thiokol RD, 154

Thiokols, A, B, FA, 155

Thomas, Dr. Phillips, 270

Thyratron, 117-118

Thyroid gland, 263

Timber Engineering Company, "Teco" ring, I9r

Time, $15 \mathrm{x}$

Tin, $124,180,181,197$

Tires, automobile, 43, 152, 154

Tobin, R. B., 223

Toennis, Dr. B., 250

Toluol, from coal-tar, 160 ; from petroleum, 162

Torque, 68

Toxic reactions, of sulfa drugs, 242 ; none in penicillin, 243

Traffic congestion, cost of, 56

Tramp shipping, I 12

Transfusions, blood, 230-23I

Transmutation of matter, 262

Transportation, air versus land, 86, ror; air versus sea, 113-114; glider "trains," 90-92; improvements in, 
6,7 ; revolutionizing of transport to aid farmer, 214

Trees, bark of, for clothing, 5

Trinitrotoluene (TNT), I60

Trippe, Juan, 98-100

Triptane, 55

Tropopause, 84

Trucks, 101-102; NRPB report on, 107; "Truck of Future," 108; war job, 107

Trueta, José, 233-234

Tryptophane, amino acid, 170, 249

Tuberculosis, 257

Tung oil, 204

Tungsten, 30, $116,117,179$

Turbine, gas, I03; steam, 104

Turpentine, 209

Tuskegee Institute, Alabama, 200

Typhoid fever, 249; vaccine, 249

Tyrian purple, 159

\section{U}

Ultrahigh frequency, 95-96; in Radar, 120; in television, 133-134, 146147

Underconsumption, and "farm problem," 199-200; during 1930s, 8

Union Carbide and Carbon Corporation, 162

United Aircraft Corporation, Sikorsky Division of, 65

United Nations, 98, 100

United States Rubber Company, 154

United States Steel Company, 8I

Urea, 163-164

Urea formaldehyde, 163

Uskol, 154

\section{V}

Vacuum, perfect, 94

Vacuum tube, 116-117

Vaccines, 249

V Day plans, reconversion, 57

Vanadium, 48, 179

Vanillin, 190, 208
Van Itallie, Philip, 225-226

Vickery, Rear Admiral Howard L., 65

Vienna, University of, $23^{8}$

Vinylidene chloride, 164

Vinyl resins, 164; polyvinyl butral, I64

Viruses, filterable, 252, 253, 257

Vitamins, 218-220; $\mathrm{B}_{1}, 223,250, \mathrm{C}, \mathrm{K}$, 229; biotin, 250; for old age, 259; niacin, 250; riboflavin, 250

"Voo Doo," 92

Vortex gun, 270-27r; as antiaircraft weapon, 27I; to rid cities of smoke, 271-272

Vortex motion, 271

Vycor, 194

W

Wagner, Dr. Martin, 214

Waksman, Dr. Selman A., 246

"Walkie-talkie," 139; postwar use on farms, 214

Wallace, Dr. James E., 244

Walnut shells, 204

War, gains and losses from, 1 ; two world wars, 2, 3, 4

War Information, Office of, 97, 105106, 185, 228, 234-235, 236, 237

Warner, Edward, 78-79

War Production Board (WPB), Office of Production Research and Development, 183

War Shipping Administration, 110, II 2

Washington, Booker T., 200

Water, distilled, 230

Water supply, 248-249

Watson-Watt, Sir Robert, I2 I

Waves, radio, I43; "carrier," 144

Waxy corn, 202

Weather, changes in, 252; prediction of, 213

Weaver, Don E., 52

Welding, and electronics, 130, 162; in shipbuilding, 109

Wendt, Gerald, 15 I 
Western Air Lines, 88

Westinghouse Electric \& Manufacturing Company, 166, 196, 270-271

Westinghouse Research Laboratories, 30,166

Wetherby, John M., 149-150

Willys-Overland Motor Co., 57

Wing flaps, 74,89

Wirth Steel Company, 8I

Wöhler, Friedrich, 164, 174

Wood, 157, 158, 198; American progress in wood chemistry, 190-192; cellulose, 208; German program, 188-190; lignin, 208; "Teco" ring, 191; war jobs of, 185

Woodruff, Dr. H. Boyd, 246

Wounded, recovery of, 228

Wright Field, Ohio, 65

Wright, Frank Lloyd, 19

Wright, Russel and Mary, 36

\section{$\mathbf{X}$}

$X$ ray, 124-125, 130; diffraction camera, 125; fluoroscopic screen, 231, 232; "liminograph," 130; mobile, 231-232

Xylol, I60

\section{Y}

Yates, Raymond, 117; 2,100 Needed Inventions, 265, 267

Yellow fever, 249

You magazine, 219

Young, Leo C., 120-12I

\section{$\mathbf{Z}$}

Zeder, Fred M., 46, 47-48

Zinc, 180 





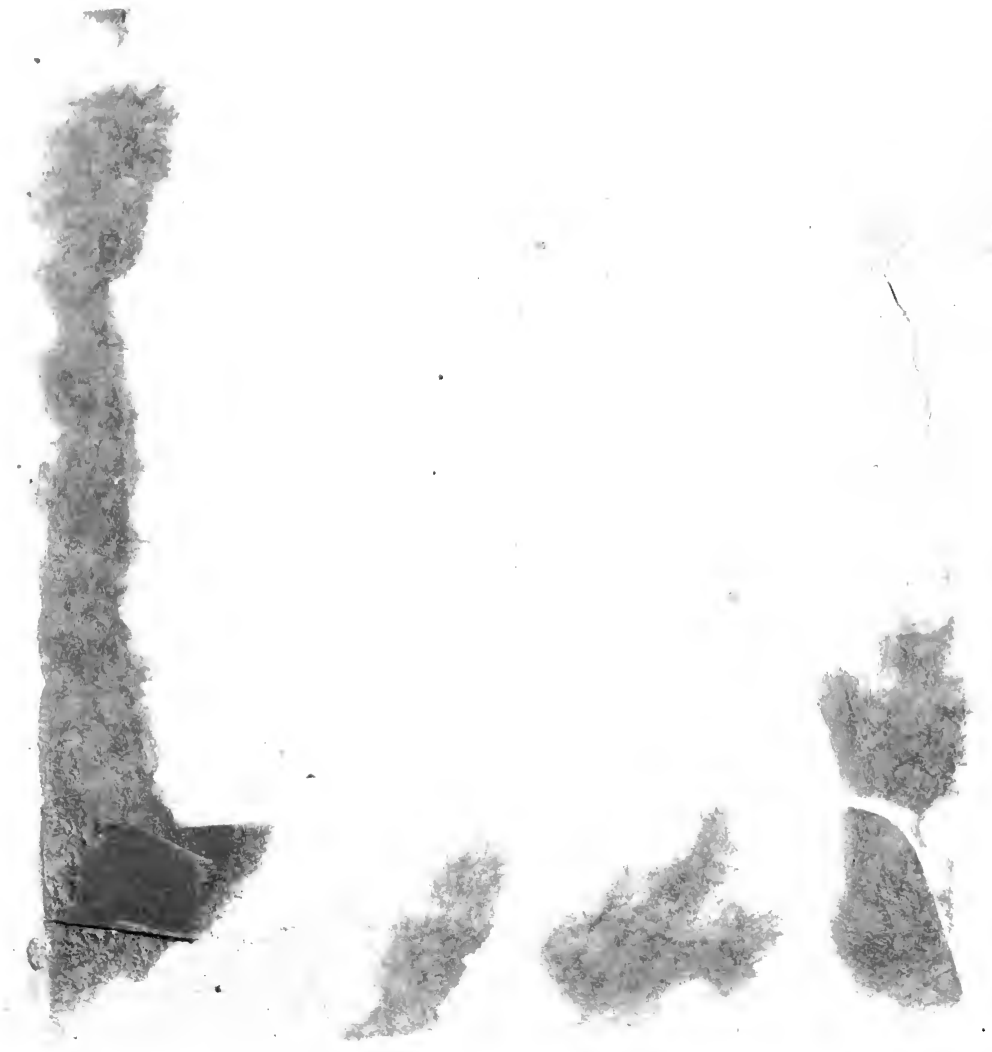
$\frac{4}{2} \cdot \frac{1}{2}$

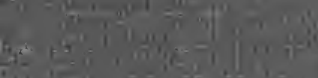

(1)

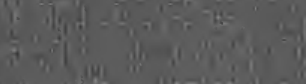

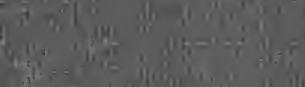

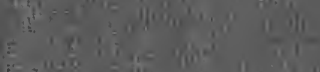

and

ati.

1.

1.

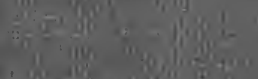

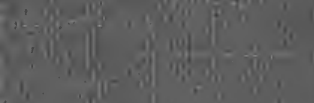

a.

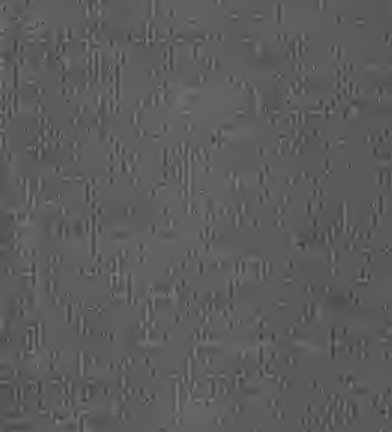

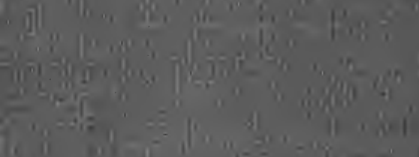

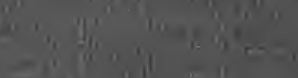
, the

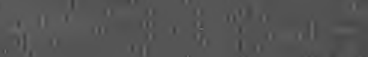

$-27-3 a^{2}$ 